Drugs, Oil, and Insurgency in Colombia

Susan Virginia Norman

Williamsburg, Virginia

Bachelor of Arts in Political Science, Stetson University, 2004

Master of Arts in Foreign Affairs, University of Virginia, 2007

A Dissertation presented to the Graduate Faculty of the University of Virginia in Candidacy for the Degree of Doctor of Philosophy

Department of Politics

University of Virginia

January, 2014 
(C) Copyright by

Susan Norman

2014

All Rights Reserved 


\title{
Drugs, Oil, and Insurgency in Colombia
}

By Susan Virginia Norman

\begin{abstract}
This dissertation compares the effects of licit and illicit commodity production on the nature of insurgent authority in frontier regions of Colombia between 1978 and 2004. Specifically, I focus on illicit drugs and oil as two commodities that are consistently linked to the onset, duration, and lethality of internal conflict. In Colombia, a puzzle arises wherein illicit drug production correlates with robust and legitimate insurgent authority at the local level. Legitimate authority is defined as the exercise of power by popular consent. In Colombian regions with oil extraction, insurgents were, in contrast, a predatory authority, exercising power based on coercion alone. When insurgents have legitimate authority, the result is less violence toward civilians in the short term, but in the long term there are greater obstacles for undermining insurgent control and establishing the authority of the state.

To explain the different effects of oil and illicit coca on insurgent authority, my central thesis underscores the role of the state. I argue that state repression of illicit coca production in Colombia created incentives for coca producers to cooperate with insurgents. Insurgents offered security and protection and in exchange the population benefited from and so consented to insurgent control. I argue that state protection of the oil industry, on the other hand, incentivized oil companies to resist insurgent control. Hence, insurgents extracted resources with coercion, over time transforming into a predatory authority.
\end{abstract}


I validate my hypothesis with a qualitative comparative case study approach. I compare Arauca and Caquetá, two Colombian departments where insurgents exercised authority. In Arauca, the discovery of a major oil field in 1983 and the subsequent militarization of the region led to deteriorating relations between the civilian population and the increasingly predatory National Liberation Army (ELN). In Caquetá, the onset of illicit coca production in 1978 and ensuing state repression allowed for the Revolutionary Armed Forces of Colombia (FARC) to exercise legitimate authority vis-à-vis the local population. 
For Valerie 


\section{CONTENTS}

Charts, Diagrams, Tables..................................................................................... vi

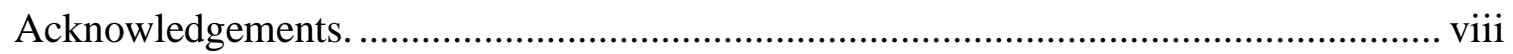

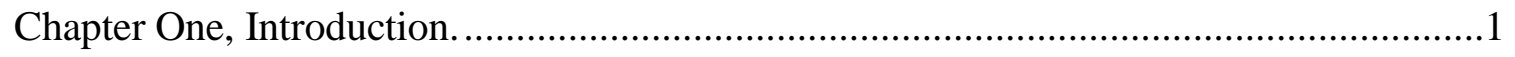

Chapter Two, War Commodities and Insurgent Authority ........................................40

Part I: Oil and Predatory Authority: The ELN in Arauca .......................................... 84

Chapter Three, Oil: State Response to a Licit Commodity …......................................85

Chapter Four, The ELN and Predatory Authority …........................................... 130

Part II: Coca and Legitimate Authority: The FARC in Caquetá.................................175

Chapter Five, Coca: State Response to an Illicit Commodity ................................... 176

Chapter Six, The FARC and Legitimate Authority ..............................................236

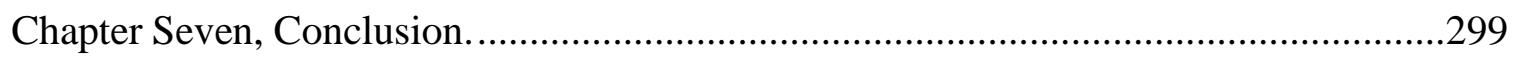

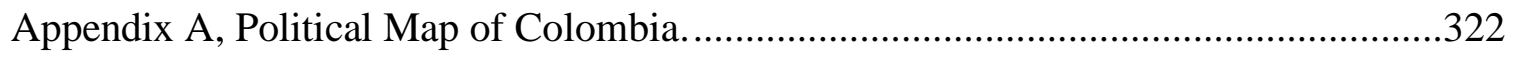

Appendix B, FARC and ELN Strongholds in Colombia.........................................323

Appendix C, Map of Coca Cultivation in Colombia, 2000-2004..................................324

Appendix D, Location of Oil Extraction and Pipelines in Colombia...........................325

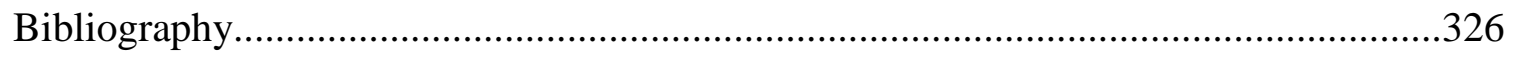




\section{CHARTS, DIAGRAMS, TABLES}

Charts

1.6, Conflict Violence in Colombia, Events (y) by Year (x), 1988-2004. ....................... 22

1.7, Homicide Rates in Coca and Non-Coca Colombian Regions, 1985-94. .................. 25

1.8, Insurgent Actions in Colombia, Coca and Oil Departments, 1985-1994..................26

1.9, Insurgent Actions in Oil Producing Departments of Colombia, 1985-1994............29

4.1, Oil Production and Insurgent Attacks in Colombia, 1986-1997........................... 150

4.2, Insurgent Attacks on the Caño-Limón Pipeline, 1988-1997..................................151

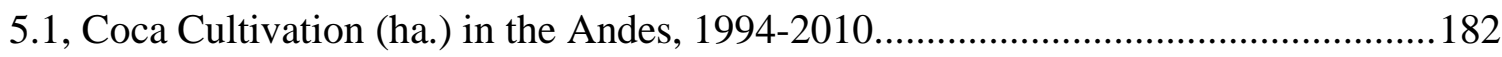

Diagrams

1.10, Concept Chart: Legitimate and Predatory Insurgency .......................................... 32

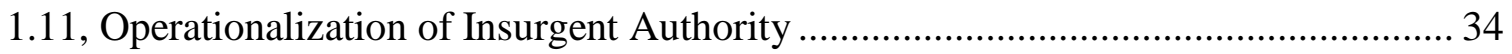

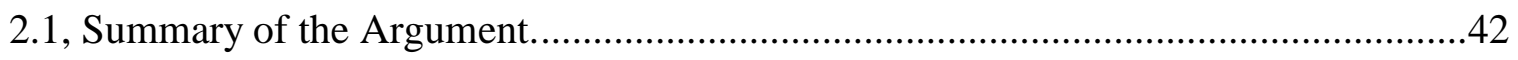

2.2, Summary of the Argument with Causal Mechanisms............................................52

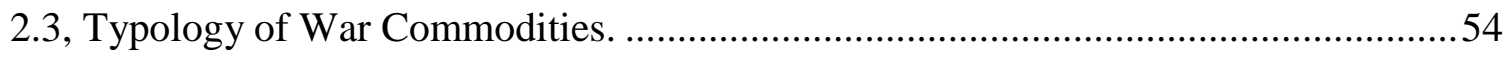

Tables

1.1, Colombian Departments with High Coca Cultivation (ha.), 1999-2004.................. 16

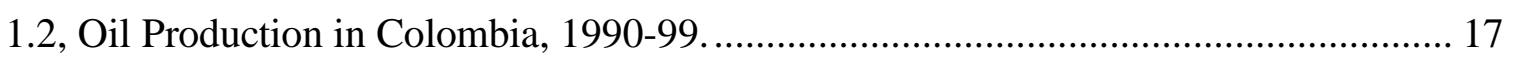

1.3, Petroleum Refineries in Colombia................................................................... 17

1.4, ELN Fighters and Territorial Control, 1974-1996............................................ 21

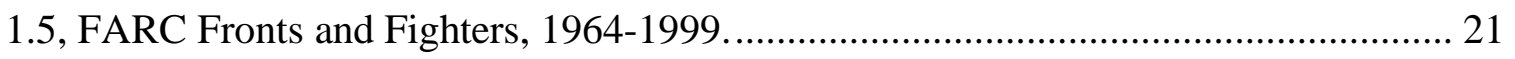

2.4, FARC and ELN Rent-Seeking Activities, 1998-1999. .......................................... 72

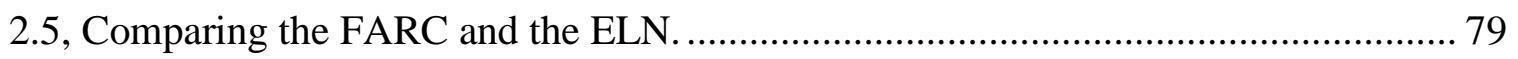

4.3, Cost of Attacks on Caño Limón-Coveñas Pipeline, 1986-1998 ............................ 159

5.2, Distribution of Value of Production of Cocaine in Colombia, 2008. ..................... 184 
5.3, the Structure of Coca Cultivation in Colombia.....................................................186

5.4, Estimate Labor and Costs of Coca Production in Colombia....................................186

5.5, FARC Attacks against Colombian Military, 1996-1999 .....................................203

5.6, Violence against Political Class by FARC and ELN, 1997-2007.........................205

5.7, State Capacity Gains in Oil and Coca Departments of Colombia, 2005.................222

5.8, Coca Area and Fumigation Area Colombian Departments, 1994-1998.................. 226

6.1, FARC Fronts and Fighters, 1964-1999........................................................... 242

6.2, Chronology: The FARC in El Caguán............................................................. 244

6.3, Chronology: FARC and the Illicit Economy in Caquetá, 1977-2001.................... 249

6.4, Insurgent Violent Actions against Anti-Narcotics Police, 1995-1997. ....................273 


\section{Acknowledgments}

This dissertation would not have been possible without the generous support and encouragement of many individuals and organizations.

I am deeply indebted to my academic adviser and dissertation chair, David Waldner, as well as my dissertation committee members, Herman Schwartz, Daniel Gingerich, and Herbert 'Tico' Braun. Their constant encouragement and helpful feedback greatly improved the quality of my work. I am also grateful to the faculty and staff in the politics department at the University of Virginia for contributing to my development as a scholar and researcher with their guidance, instruction, and friendship. My years as a graduate student were a time of tremendous personal and professional growth. I was fortunate to take that journey surrounded by so many great people.

The completion of my research would not have been possible without the generous support of three organizations. My first round of field work in Colombia in 2011 was supported by the Drugs, Security and Democracy (DSD) Fellowship of the Social Science Research Council and the Open Society Foundations. In addition to providing financial support, the DSD network has also provided me with fantastic feedback, fieldwork workshops, and mentorship throughout the research and writing stages of this dissertation. I am particularly grateful to Paul Gootenberg for his helpful comments, friendship, and enthusiasm for my project. In 2012, I was fortunate to return to Colombia for a second round of research with the financial support of the Albert 
Gallatin Dissertation Research Fellowship of the Thomas Jefferson Memorial Foundation at the University of Virginia.

I am also grateful to the many organizations and individuals that assisted me during my field work in Colombia. The following organizations generously provided access to data and archives, and facilitated interviews: the Permanent Committee for the Defense of Human Rights (CPDH), the Center for Research and Popular Education (CINEP), the Program for Peace and Reconciliation in Medellín, the Colombian Agency for Reintegration (ACR), the Care Program for the Demobilization and Reintegration Process in Bogotá (PAPDRB), and the Corporación Nuevo Arco Iris. In addition, Luis Celis Méndez, Ildelfonso Henao, and Luz María Londoño kindly gave of their time and resources so that I could access information and populations that were otherwise out of my reach. The Pontificia Universidad Javeriana in Bogota graciously provided me with space to work and library access. At Javeriana, Pedro Valenzuela was my (unofficial) field work adviser and also welcomed my daughter and me into his home during our first days in Bogota. A special thanks goes to Camilo Sánchez Meertens for opening doors for my research, for sharing much needed breaks over coffee, and most especially for being such a great friend.

I also want to thank the many research participants that voluntarily gave of their time, knowledge, and experiences so that I could write this dissertation. Their names will remain confidential, but their contribution to this project cannot go without special recognition. No academic study can truly capture the human tragedy brought by six decades of war, nor the unwavering determination and hope of the Colombian people to 
find the long-awaited peace. I am deeply grateful for the opportunity to be informed, affected, and inspired by the testimonies of the many demobilized combatants, community leaders, and civilians who shared with me their personal stories of conflict. Thank you.

I am also indebted to so many friends who have supported me throughout the long process of dissertating. At the University of Virginia, Elyssa Van Osten Dunfee has been a constant friend from the early years of graduate school through the completion of this project and beyond. I also thank Hilde Restad, Kyle Lascurrettes, Nadim Khoury, Katelyn Sacks, and Ana Alves for sharing good (and bad) times during graduate school. I have so many fantastic memories.

Beyond the University, I found Charlottesville to be a beautiful community where I was always surrounded by great friends. Natalie Hetzel, Lindley Stakem, and Amelia Walton gave the best excuses to enjoy some much needed distraction. They also kept me grounded, and helped me through some difficult moments. Pamela Panetta Formica is the kindest person I know, and she gave many hours of her time to care for my daughter so that I could write and teach. Lastly, Butch Bailey, Edwin Roa, and the Charlottesville Salsa Club helped me to find my Zen on the dance floor. Thank you for teaching me that a contented mind is a more productive one.

During the research stage of this dissertation I was also very fortunate to be a part of the Drugs, Security, and Democracy (DSD) fellowship family. The DSD fellowship and workshops allowed me to improve and expand this project with the support of many excellent mentors and scholars, all of whom I consider my friends. Among my DSD 
family, I owe a special thanks to Yanilda González, Daniel Esser, Ellen Sharp, Angélica Durán-Martínez, Adam Baird, and Reynaldo Rojo Mendoza for their support and friendship. I am so very grateful to Javier Osorio for his constant encouragement, care, and support especially during the last months of writing, and for always believing in me, even though I often doubted myself.

I owe an enormous debt of gratitude to my family. Without the love and support of all four of my parents, Mom, Dad, Harry, and Pat, I would never have made it to graduate school, much less through nine years of graduate study. They have all contributed to the person I am in unique and special ways. I also thank my big sisters, Dorothy and Abby, my brother-in-law John, my grandparents, Granny, Grandpop, and Bob, and my beautiful nieces and nephews for always welcoming me home with love and smiles. I owe a special thanks to Danny, the only other person who can fully appreciate what an incredible journey this dissertation has been. Thank you for being a part of it.

Last and most important, I thank my daughter, Valerie, who sacrificed more than anyone (myself included) so that I could write a dissertation. For the first five years of her life, Valerie generously shared her mom with this project. I dedicate this dissertation to her with love and gratitude. 


\section{Chapter One}

\section{Introduction}

In 1978, the insurgent group Revolutionary Armed Forces of Colombia (FARC) arrived in Cartagena del Chairá, a peasant community in the Colombian department of Caquetá, about 250 miles south of the capital city of Bogotá. ${ }^{1}$ One year later, Cartagena del Chairá was at the center of an illicit coca bonanza. Narcotics traffickers came from Medellín with coca seeds and offered the peasants $\$ 1,200$ pesos per gram of cultivated coca leaf. The promise of fast profits attracted thousands of newcomers to the quiet frontier community. The local Community Action Board (JAC), the only authority in Cartagena del Chairá, was overwhelmed by the population explosion and the consequent upsurge in thefts, assaults, and homicides. In 1985, JAC leaders appealed to Colombian President Belisario Betancur to remedy the problem of illicit cultivation and crime. Yet, two years later the Colombian government declared Caquetá a "red zone" (conflict zone) and excluded the department from development assistance. Afterwards, the military was sent in and forced eradication of illicit coca was initiated. ${ }^{2}$

In this context of state neglect and repression, the peasants of Cartagena del Chairá turned to the FARC to re-establish order. In 1982, the FARC began offering military and economic protection to illicit cultivators. In exchange, illicit cultivators paid the FARC a 10 per cent tax on coca sales. The FARC used the illicit rents to expand their military organization and support the Community Action Board in enforcing a strict

\footnotetext{
${ }^{1}$ Author interview with Graciela Uribe, November 7, 2011 in Bogotá, Colombia; also see Molano 1988; Espinosa 2010: 73; Contreras Tiguaque 2010: 75; Richani 2002: 70

${ }^{2}$ Uribe 2001: 204; Jaramillo et al. 58-63, 147, 155, 199-201, 219
} 
criminal code. In addition, new schools, roads, river ports, and towns were built to support the growing population and facilitate trade, both licit and illicit. ${ }^{3}$ In 1989 , violent crime had virtually ceased in Cartagena del Chairá. Meanwhile, the FARC became the wealthiest and most powerful insurgent organization in Latin America. The FARC brought order and economic security in the absence of the state. As a result, the population assented to the FARC's authority, and for a while Cartagena del Chairá was a community at peace amid tremendous conflict. ${ }^{4}$

The story of Cartagena del Chairá matters because it contradicts the conventional wisdom that illicit commodity production fuels guerilla violence. ${ }^{5}$ Cartagena del Chairá is not extraordinary. Rather, Cartagena is emblematic of numerous peasant communities across Colombia's frontier south and east of the capital city of Bogotá. ${ }^{6}$ Beginning in the 1980s that territory made up the rearguard zone of the FARC, a peasant insurgency that was formed in 1964. Cartagena was also the site of an illicit coca bonanza in 1979. Illicit production coincided with FARC control, producing the most durable non-state orders of the Colombian conflict. In these communities, the FARC forged a powerful coalition with illicit cultivators and exercised legitimate authority based on popular consent.

The story of Cartagena del Chairá also matters because the outcomes deviate from most other Colombian regions where insurgents exploited licit commodities. In the oilrich department of Arauca, the population suffered tremendous losses and insecurity at the hands of the National Liberation Army (ELN). Beginning in 1983, the ELN's local

\footnotetext{
${ }^{3}$ Jaramillo et al. 1989: 258

4 ibid: 267

${ }^{5}$ Pecaút 1997; Rabasa and Chalk 2001: xiii; Echandía 1999: 79-81; Holmes et al. 2008, 2009
} 
front Domingo Laín used ransom kidnappings, extortion, and violent attacks on oil infrastructure to extract rents from oil companies and their contractors. ${ }^{6}$ At the same time, Domingo Laín used coercion to capture oil royalties for their peasant supporters at the expense of other sectors of the population. Arauca, one of Colombia's wealthiest departments, was economically insolvent by the late 1990s. Domingo Lain's rent-seeking activities cost the department millions due to pipeline repairs, spilled oil, production stoppages, polluted waterways, and uncultivable land. In addition, violent attacks on the oil infrastructure resulted in hundreds of deaths and many more injuries. After a decade of violently extorting the oil sector, Domingo Laín had lost much local support, and increasingly relied on coercion to control the population.

The story of Arauca epitomizes the predatory authority imposed by Colombian insurgents in numerous frontier communities that were rich in natural resources, especially oil. Moreover, practically all Colombian non-state armed groups exercised predatory authority in one or more communities, including the ELN, the FARC and rightwing paramilitary groups. Hence, predatory authority correlates with a type of commodity and not with any particular armed actor. The oil-rich department of Casanare is particularly illustrative of this dynamic. There, British Petroleum suffered simultaneous attacks on their installations by multiple non-state armed groups with distinct ideologies. ${ }^{7}$ Between 1992 and 2004, insurgents bombed Colombia's oil pipelines more than 1,000 times resulting in the loss of about 2.9 billion barrels of crude oil. ${ }^{8}$

\footnotetext{
${ }^{6}$ Peñate 1998; Pearce 2005

${ }^{7}$ Pearce 2004: 13-16

${ }^{8}$ Dunning and Wirpsa, 2004
} 
The objective of this dissertation is to compare and explain the effects of illicit and licit commodities on the nature of insurgent authority with a sub-national level analysis of the Colombian conflict at the end of the twentieth century. The Colombian communities of Cartagena del Chairá and Arauca reveal two discrete types of insurgent authority: legitimate and predatory. In Cartagena the FARC's authority was legitimate which means that the local population consented to the imposition of non-state power. Locals obeyed the FARC based on the perception that insurgent authority was just and even beneficial. In Arauca, the ELN's authority was predatory or based solely on coercion. The population obeyed the ELN merely to avoid violence. In both cases, civilians were acting to maximize their physical and material security in a context of war.

I base my analysis on the Colombian conflict because it is a case of significant local variation within one conflict. Insurgents have financed their activities by exploiting diverse resources. Colombia offers a particularly auspicious opportunity to compare the effects of drugs and oil, two commodities consistently correlated with protracted civil conflict. ${ }^{9}$ In the early 1980 s, the Colombian conflict was transformed by resource booms in illicit drugs and oil that occurred almost simultaneously but in different frontier regions. At the national level, the production of oil and drugs in Colombia contributed to an ever more violent and predatory war. And yet, in the frontier communities where commodity production took place, oil and illicit coca had very distinct effects on insurgent interactions with civilian populations.

\footnotetext{
${ }^{9}$ see especially Ross 2003, 2004
} 
My core thesis identifies the state as the key actor shaping different types of insurgent authority in regions with oil and coca. Illicitness is a politically determined quality of resources. When governments designate a commodity and its production to be illicit, the state security apparatus is deployed to repress economic activity. In Colombia, the state responded to coca producers first with political abandonment, and then with widespread forced eradication of coca crops. I argue that by repressing illicit commodity production the state creates conditions for insurgents to exercise legitimate authority. State repression increases the already high level of insecurity faced by illicit drug producers. In this context, resource-hungry insurgents capitalize politically and economically by delivering order and security in exchange for a share of the economic surplus.

Not all states respond to drug production with repression. In Bolivia, coca production was mostly tolerated. Early on, the Bolivian government was inclined to favor voluntary eradication and then alternative development in place of criminalizing coca producers. In Peru, coca production is illicit and was forcibly eradicated beginning in the early 1980s. Subsequently, the insurgent group Shining Path (SL) was able to exercise legitimate authority in Peru's coca-producing region, the Upper Huallaga Valley (UHV). There, local support for SL was high relative to other regions where SL ruled with extreme brutality. However, by the mid-1990s the Peruvian government halted forced eradication of coca in favor of targeting drug traffickers with interdiction. The policy 
change coincided with declining support for the Shining Path and an increase in insurgent predation toward the local population in the UHV. ${ }^{10}$

The comparison of Colombia with neighboring Bolivia and Peru suggests that it is not the presence of drug production as much as criminalization and state repression that creates conditions for insurgents to exercise legitimate authority in Colombia. Among the three Andean states that produce coca Colombia has maintained the most repressive policies toward illicit drug cultivators. ${ }^{11}$ The explanation for Colombia's more repressive policy is exogenous to my argument. However, three factors stand out as important. First, the United States is a major source of external aid and a trading partner of Colombia. Challenging U.S. drug policy by legalizing coca would be economically disastrous for Colombia. Second, Colombia's illicit cultivators are politically weak especially compared to those in Bolivia and cannot organize a resistance against government attacks on illicit production.

The third factor driving the Colombian government to prohibit and repress coca cultivation is that drug cartels control the coca market in Colombia, and the cartels threaten the political establishment even while drug money supports individual politicians as campaign financing and bribes. Beginning in the late 1980s, Colombian drug capos such as Pablo Escobar emerged from the shantytowns of Medellín and Cali to become a political force in opposition to traditional elite authority and with the support of much of

\footnotetext{
${ }^{10}$ Felbab-Brown 2009: 35-68; McClintock 1984

${ }^{11}$ In 1998 Colombia became the dominant supplier of illicit heroin to the United States, surpassing traditional source states such as Afghanistan and Burma. Illicit opium poppy cultivation in Colombia has declined alongside coca production in recent years. See UNODC World Drug Report, 2012: http://www.unodc.org/documents/data-and-analysis/WDR2012/WDR_2012_web_small.pdf
} 
the urban poor population. Indeed, Pablo Escobar in particular brought tremendous violence but was also an effective local patron who delivered roads, schools, and public works projects to Medellín's neglected urban periphery. In contrast, Bolivia and Peru do not contend with powerful drug trafficking cartels. There the 'problem of drugs' has always been mostly confined to rural regions, distant from the centers of power.

In Colombia the decision to criminalize drug production was an executive decision that was unanimously supported by Colombian legislators. In 1978, Colombian President Julio César Turbay Ayala implemented the country's first drug eradication campaign to undermine a thriving marijuana trade in the Caribbean region. Marijuana smugglers then turned to the cocaine trade. President Belisario Betancur (1982-1986) was initially disposed to adopt alternative development as a solution to the coca, but received little Congressional or military support. The 1984 assassination of Colombian Minister of Justice Rodrigo Lara by the Medellín drug cartel decisively undermined any possibility for a policy of toleration. ${ }^{12}$ Forced eradication of coca was initiated in 1986 under President Virgilio Barco Vargas, and the policy has been upheld without opposition under succeeding Colombian presidents including César Gaviria (1990-1994), Ernesto Samper (1994-1998), Andrés Pastrana (1998-2002), Álvaro Uribe (2002-2010), and Juan Manuel Santos (2010-present).

Colombia's policy of repressing coca production contrasts with state protection of other lucrative commodities targeted by insurgents. In Colombia, the government used military force to protect the oil industry, an industry that generated substantial revenue

\footnotetext{
12 Jaramillo et al. 1989: 151-152
} 
for the government. Indeed, Colombia's national security expenditures in oil-producing regions far surpassed those in all other conflict zones. ${ }^{13} \mathrm{I}$ argue that insurgents become more predatory in the presence of lucrative and licit natural resources precisely because state protection of these industries precludes insurgents from using a more cooperative economic strategy. In Colombia, oil companies were already paying rents to the state in exchange for military protection, and hence faced both economic and political incentive to resist cooperative exchanges with insurgents. As a result, the ELN extracted resources coercively, gaining at the expense of licit producers and the local population. Over time, ELN coercion was met with civilian resistance resulting in predatory authority.

The main objective of this dissertation is to develop and test the above hypotheses with a qualitative comparative analysis of the FARC and the ELN and their interactions with populations engaged in coca and oil production in Caquetá and Arauca between 1978 and 2004. The FARC and the ELN emerged as insurgent organizations during the 1960s, prior to any significant coca or oil production in Colombia. Neither insurgent organization was a significant threat to Colombia's national government in Bogotá prior to the booms in oil and coca that occurred in the last two decades of the twentieth century. Beginning with state policies that protect oil multinationals while repressing coca cultivators, I trace the process by which the Colombian state shaped the ELN's and FARC's economic strategies. I then link coercive and cooperative strategies to the nature of insurgent authority.

\footnotetext{
${ }^{13}$ Holmes and Piñeres 2012: 101, 113, 118
} 
The remainder of this chapter introduces the reader to the core questions and concepts that are the basis for my research. I begin with the political context in Colombia that gave rise to insurgent groups in the 1960s, and describe how decades later commodity booms in drugs and oil transformed the national conflict as well as the communities in which insurgents operated. The empirical account of how drugs and oil corresponded with different types of local insurgent authority in Colombia frames my research question and provides the groundwork for precisely defining the two outcomes to be compared; legitimate and predatory authority. Finally, I discuss why my research matters. With this work, I contribute theoretical knowledge of how policy choices surrounding economic activity shape the dynamics of civil war. The state is an omitted variable in the literature on resources and conflict. My research establishes that states matter, and that policies can have unintended consequences.

\section{The Context: Insurgency and Commodity Booms in Colombia's Frontier}

While drugs and oil had a profoundly transformative effect on the nature of conflict, the Colombian conflict is not a resource war. Rather, the formation of leftist insurgent organizations in Colombia predates any significant coca and oil production by nearly two decades. In this section I describe how the convergence of lucrative commodities and insurgency was something of a historical coincidence. Insurgents and resource booms constitute two autonomous events with distinct political and economic origins that nonetheless collided in the Colombian frontier during the 1980s and 1990s. 


\section{The Insurgents}

The most economically stable and democratic Andean nation, Colombia has nonetheless been burdened with multiple internal threats to state sovereignty since the 1960s, including four major insurgencies and at least twenty-two autonomous right wing paramilitary organizations. The Revolutionary Armed Forces of Colombia (FARC) and the National Liberation Army (ELN) are the two largest and most consequential insurgent groups. The FARC and the ELN emerged as leftist guerilla organizations in 1964. However, both trace their origins to the peasant self-defense movement of the 1930s and the Liberal and Communist guerilla bands that formed during a period of civil war in Colombia known simply as La Violencia (1948-1963).

La Violencia was a particularly violent struggle between Colombia's two dominant Liberal and Conservative political parties. At the national level, La Violencia was an intra-elite battle; a power struggle within the Colombian oligarchy. Conflict began with the assassination of the Liberal party's populist presidential candidate, Jorge Eliécer Gaitán Ayala, on the streets of Bogotá in 1948. ${ }^{14}$ Gaitán's supporters in Bogotá, including working and middle class groups, reacted to Gaitán's assassination with a mass riot known as the bogotazo. Violence in the capital city spread to the countryside incorporating large sectors of the peasant population.

In the countryside, Conservative forces in control of local government posts launched a wave of attacks on Liberal party elites and Liberal-identifying peasant communities. Liberal party bosses reacted by organizing the peasants into guerilla self-

\footnotetext{
${ }^{14}$ See Braun 2003
} 
defense groups. As the conflict took on more sinister forms, peasants also became involved in banditry or took advantage of the disorder to use violence to resolve personal vendettas. The banditry continued until 1963, but La Violencia officially ended in 1958 with the signing of the National Front agreement. The National Front was a powersharing arrangement between Liberals and Conservatives that lasted until 1974. ${ }^{15}$

Under the National Front the power of Colombia's traditional oligarchy was protected within a semi-democratic framework. Meanwhile, popular forces in the countryside that were mobilized by Liberal party bosses during the war were excluded from political participation along with more radical political forces such as the Colombian Communist Party (PCC). ${ }^{16}$ The political exclusivity of the National Front in combination with unresolved problems of rural underdevelopment and inequality contributed to the formation of leftist insurgent organizations in Colombia during the 1960s. ${ }^{17}$ In addition to the FARC and the ELN, other significant insurgent organizations that emerged included the Popular Liberation Army (EPL) and the April $19^{\text {th }}$ Movement (M-19). Both the EPL and the M-19 demobilized in 1991 and formed legal political parties. The FARC and the ELN remain active.

The FARC formed in the early 1960s as a loose network of displaced peasant guerilla bands that settled in the central Andean departments of Tolima, Huila, and Caldas. The region made up part of the Colombian coffee belt, the area most prone to

\footnotetext{
${ }^{15}$ Oquist 1981; Sánchez and Meertens 1984

${ }^{16}$ Under the National Front, the office of President alternated between the Liberal and Conservative party every four years.

${ }^{17}$ In Colombia the social question had two dimensions: the rural dimension which had to do with the unequal distribution of land and rural reform, and the urban question which had to do with extending political inclusion to the urban middle and working classes.
} 
outbreaks of violence against Liberal peasant communities during the 1950s. There, the guerilla bands constructed 'independent republics' that were economically self-sufficient peasant communities. The independent republics were considered a threat to the National Front government. ${ }^{18}$

On May 27, 1964, the Colombian government carried out Operation Marquetalia, a military offensive against the largest independent republic in the department of Tolima to the southwest of Bogotá. ${ }^{19}$ Though armed, the peasant community of Marquetalia was overwhelmed and ultimately driven out of Tolima. In the aftermath of the devastating attack, 45 remaining armed peasant leaders fled with a handful of families to the jungles of the eastern and southern frontier. There they found willing recruits among peasant settlers displaced by violence during the previous decade. ${ }^{17}$ On July 20, 1964, the remaining peasant forces of Marquetalia formed the Revolutionary Armed Forces of Colombia (FARC) and declared war on the Colombian state. ${ }^{20}$

The National Liberation Army (ELN) also formed in 1964. Inspired by the Cuban Revolution and led by university students, union leaders, and Catholic priests, the ELN drew on a strong urban social base in contrast to the peasant origins and membership of the FARC. ${ }^{21}$ However, the mostly urban leadership of the ELN recruited a peasant following, particularly in the Magdalena Medio and Caribbean departments of Santander, North Santander, and Bolívar. Like the southeastern frontier, the Magdalena Medio and Caribbean regions were also settled by peasants displaced during the violence of the

\footnotetext{
${ }^{18}$ Henderson 1985

${ }^{19}$ Matta 1990:47-52; Arenas 1985: 81-84

${ }^{20}$ Arenas 1985: 92

${ }^{21}$ Richani 2002: 84
} 
1950s. In particular, the liberal guerilla bands from Santander left a strong legacy of armed self-defense that the ELN exploited in its initial recruitment. The first ELN front was composed of 18 armed peasants who were sons and relatives of former members of the Liberal guerilla forces in the municipality of San Vicente de Chucuri in northeastern Santander on the border with Venezuela. ${ }^{22}$

The FARC and the ELN were weak guerilla organizations during the 1960s and 1970s. At that time, both insurgent organizations engaged in sporadic and mostly defensive military operations with government forces. The FARC and the ELN endured only because they were able to take cover in frontier and jungle regions with the support of populations far from the central government in Bogotá. However, the onset of significant illicit coca production in 1978 and the discovery of major oil reserves in 1983 transformed the FARC and the ELN into formidable armed organizations with control over large parts of the national territory. ${ }^{22}$

\section{Coca and Oil Commodity Booms}

Coca leaf is not a traditional crop of Colombia. Prior to the 1980s, most coca cultivation took place in neighboring Peru and Bolivia where it had been produced by indigenous groups for centuries. There, raw coca leaf is regularly consumed as a medicinal remedy for fatigue, altitude sickness, and general malaise. Colombian drug traffickers bought raw coca from Peruvian producers and transported it to Colombia where they processed it into cocaine to be sold in the United States and Europe. However, after 1978 coca production began to shift to Colombia where it was cultivated

\footnotetext{
${ }^{22}$ Rodríguez and Pizarro 2005: 137; see Appendix B
} 
illegally to make cocaine for foreign markets. The first coca bonanza in Colombia happened in the southeastern departments of Caquetá, Guaviare and Meta. Caquetá was part of the vast Amazon frontier, while Guaviare and Meta belonged to the expansive eastern plains.

Coca was at first grown quietly by small, isolated peasant communities. However, in the 1990s Colombian coca production increased dramatically mostly due to successful interdiction and eradication campaigns carried out in the Upper Huallaga Valley of Peru. ${ }^{23}$ A secondary factor explaining coca cultivation in Colombia was the decentralization of the Colombian drug market from a two-cartel system to a proliferation of much smaller cartelitos (baby cartels). The cartelitos did not have access to the elaborate international networks used to import raw coca from Peru. For them, it was a costly, high-risk process. Therefore, the cartelitos encouraged cultivation in isolated regions of Colombia where the area dedicated to illicit drug cultivation increased by 500 percent between 1978 and 2001. ${ }^{24}$ By 1998, Colombia was the world's top producer and exporter of illicit coca and its psychoactive derivative, cocaine. ${ }^{25}$

Within a few years of the onset of illicit coca cultivation in the country, two large oil fields were discovered in Colombia. The first was discovered in the department of Arauca, an isolated region that shares a border with Venezuela to the east. There, in 1983 the U.S. multinational Occidental Petroleum (Oxy) discovered significant crude oil deposits at the mouth of the Caño Limón River. Three years later British Petroleum

\footnotetext{
${ }^{23}$ McClintock 1985; Fukumi 2008; Thoumi 1995; Gootenberg 2008

${ }^{24}$ Felbab-Brown 2009: 72

25 Thoumi 1995: 88; Richani 2002: 96, footnote
} 
Company (BP) discovered an even larger field in the neighboring department of Casanare. Once BP began extracting oil, the Cuisiana-Cupiagua oil field produced at 800,000 barrels per day (bpd). Meanwhile, in Arauca Caño-Limón provided about 500 million barrels of crude oil in total. ${ }^{26}$ The oil discoveries made Colombia once again a net exporter of oil, a status that had been lost in the 1950s. Moreover, the discoveries continued to attract foreign investment in new exploration.

In addition to oil, Colombia is also the world's largest emerald producer with a yearly production of about 9 million karats, and Latin America's largest producer of gold with over one million ounces of gold mined a year. ${ }^{27}$ It was gold that attracted the Spanish conquistadors to the territory that is modern day Colombia during the sixteenth century, and gold was Colombia's primary export until the country started exporting coffee in the mid-nineteenth century. During Colombia's long half-century of conflict insurgents have exploited all of Colombia's natural resources in order to finance their military activities. Indeed, new armed organizations emerged with the sole purpose of controlling black markets in emeralds and gold. However, because of its high value and attractiveness to foreign investors, oil, more than any other natural resource commodity, has shaped the dynamics of conflict in Colombia.

Commodity booms in oil and coca occurred precisely in those isolated frontier regions where the FARC and the ELN had set up their rearguard zones. ${ }^{28}$ Illicit coca cultivation was concentrated in the departments of Caquetá, Guaviare, Meta, and

\footnotetext{
${ }^{26}$ Dunning and Wirpsa 2004: 86

${ }^{27}$ Levaux 2007: 20

${ }^{28}$ Fearon and Laitin 2003
} 
Putumayo, though it later spread to areas even further from Bogotá including the departments of Nariño, Bolívar, and North Santander. ${ }^{29}$ Caquetá, Guaviare and Meta make up the historic rearguard zone of the FARC.

Table 1.1, Colombian Departments with High Coca Cultivation (ha.), 1999-2004 ${ }^{30}$

\begin{tabular}{|l|r|r|r|r|}
\hline Year & 1999 & 2001 & 2003 & 2004 \\
\hline Bolívar & 5,897 & 4,824 & 4,470 & 3,402 \\
\hline Caquetá & 23,718 & 14,516 & 7,230 & 6,500 \\
\hline Guaviare & 28,435 & 25,553 & 16,163 & 9,769 \\
\hline Meta & 11,384 & 11,425 & 12,814 & 18,740 \\
\hline Nariño & 3,959 & 7,494 & 17,628 & 14,154 \\
\hline N.Santander & 15,039 & 9,145 & 4,471 & 3,055 \\
\hline Putumayo & 58,297 & 47,120 & 7,559 & 4,386 \\
\hline
\end{tabular}

Likewise, oil extraction and transport in Colombia concentrated in regions far from the capital city of Bogotá including the eastern plains and Caribbean departments of Boyacá, Arauca, Santander, eastern Antioquia, and Casanare. All or part of these departments were economically and politically marginal prior to the discovery of oil. The largest oil refinery in Colombia is located in the city of Barrancabermeja in Santander, the birthplace of the ELN. In Arauca, the ELN's front Domingo Laín had consolidated a presence several years before oil was discovered. The Caño Limón oil field was located in the region of Sarare, which was colonized by peasant settlers in the 1950s and 1960s. The peasant community of Sarare was the social support base of Domingo Laín in Arauca.

${ }^{29}$ UNODC Colombia Coca Cultivation Survey 2010

${ }^{30}$ UNODC Colombia Coca Cultivation Survey 2005; also see Appendix C 
Table 1.2, Oil Production in Colombia, 1990-9931

\begin{tabular}{|l|l|r|l|}
\hline Region & Departments & Prod. Avg. & $\%$ \\
\hline Center & Meta & 148.5 & 29.5 \\
\hline Northeast & Casanare, Boyacá & 128.4 & 25.5 \\
\hline $\begin{array}{l}\text { Magdalena } \\
\text { Medio }\end{array}$ & $\begin{array}{l}\text { Santander, Cesar, Bolívar, } \\
\text { Antioquia }\end{array}$ & 77.2 & 15.3 \\
\hline Orinoco & North Santander & 72.7 & 14.4 \\
\hline South & $\begin{array}{l}\text { Putumayo, Nariño, Cauca, Huila, } \\
\text { Tolima }\end{array}$ & 68.6 & 13.6 \\
\hline
\end{tabular}

Table 1.3, Petroleum Refineries in Colombia ${ }^{32}$

\begin{tabular}{|l|c|c|}
\hline Refinery & Department & Capacity (b/d) \\
\hline Barrancabermeja & Santander & 205,000 \\
\hline Cartagena & Bolivar & 75,000 \\
\hline Empresa Colombiana de Petroleos & Meta & 2,250 \\
\hline Tibu & N. Santander & 1,800 \\
\hline Orito & Putumayo & 1,800 \\
\hline Total & & $\mathbf{2 8 5 , 8 5 0}$ \\
\hline
\end{tabular}

\section{The State and National Territory}

The focus of my research is the frontier communities where insurgency collided with commodity booms in oil and illicit drugs during the 1980s and 1990s. Even at the end of the twentieth century, large parts of Colombia's outlying territories remained politically and economically unintegrated. Colombians referred to these marginalized areas as the 'national territory' in reference to the state's historic neglect and lack of a

${ }^{31}$ Ecopetrol; http://www.ecopetrol.com.co/contenido.aspx?catID=376\&conID=43160; see Appendix D

32 Ecopetrol: http:www.geni.org/globalenergy/library/national_energy_grid/colombia 
clear project for political and economic integration. The national territories defined the geographic boundaries of the nation, but were beyond the government's political and economic sphere of control.

In 1978, when the coca bonanza began in the Western Amazon, the heart of the national territory, the department of Caquetá lacked a regional configuration altogether. In fact, Caquetá was a tropical backwater that was annexed first to the department of Cauca and then Tolima. Together, Caquetá and Tolima formed a vast unexplored territory known as Tolima Grande. ${ }^{33}$ Likewise, when oil was discovered in Arauca in 1983, the area was not yet considered a department of Colombia. The presence of the state was minimal, and the communities had a strong llanero identity that was distinctly Venezuelan, not Colombian. ${ }^{34}$

During the 1950s and 1960s Colombia's national territory was transformed into a colonization zone. Violence between Conservative and Liberal forces and declining coffee prices drove thousands of landless peasants into the vast frontier east and south of the capital city of Bogotá. The result was a scattering of numerous peasant communities that were mostly egalitarian, self-organized, and engaged in subsistence agriculture.

The state was not entirely absent from the colonization process. Rather, the national government attempted to control the settlement of public lands by establishing civil society organizations and planning boards within frontier communities. The most important organizations were the Colombian Institute of Agrarian Reform (INCORA; Spanish acronym) and the Community Action Boards (JACs; Spanish acronym).

${ }^{33}$ Jaramillo et al. 1989: 8

${ }^{34}$ Author interview with former government official, January 21, 2012, Arauquita, Arauca, Colombia 
INCORA and the JACs were decentralized organizations tasked with mediating between the national government in Bogotá and the nearly autonomous peasant settlements dispersed through the frontier. ${ }^{35}$ However, in many instances both organizations operated outside of national government control. Resources came from the federal government, but local power holders strongly influenced how INCORA and the JACs used and distributed those resources.

INCORA was created in 1961 in an attempt by the national government to implement some type of agrarian reform. With respect to national territory, INCORA's main function was to purchase or expropriate unproductive land and make it available to settling peasants through loans. INCORA was particularly active in the titling of public lands across the national territory. The majority of the 61,217 families granted land titles by INCORA between 1962 and 1967 were peasant settlers. ${ }^{36}$ However, while the intent behind INCORA was to provide federal control over the settlement of the frontier, INCORA operated far from the capital city of Bogotá and was practically autonomous in its decisions at the local level. Hence, the work of INCORA was strongly influenced by local political brokers such as political party bosses and eventually non-state armed actors including drug traffickers, paramilitary warlords, and insurgent organizations.

Likewise, Community Action Boards (JACs) were created in the late 1950s to de-radicalize rural peasant movements and exert some governance over frontier communities. The JACs were the result of federal legislation and were conduits through

\footnotetext{
35 Jaramillo, et al. 1989

${ }^{36} \mathrm{El}$ Tiempo, Primer gran intento de reforma agraria en Colombia, Retrieved online: www.eltiempo.com/100/dk100/cronologia_centenario/
} 
which federal funds and development plans could reach the frontier. However, JAC members were locally elected leaders with roots in the community. As a result, many JACs were strongly influenced by militant peasant organizations and insurgents. As federal funding for JACS decreased in the 1970s, insurgents infused the JACs with resources in order to exercise influence over local communities. In the end, the JAC was a social organization created by the national government that was usurped by insurgents and sometimes rightist paramilitaries - and transformed into an instrument of non-state control. ${ }^{37}$

In the 1980s, weak state control and insurgency in the colonization zones met with a sudden explosion in the production of illicit drugs and oil. The result was the extraordinary military growth and territorial expansion of the FARC and the ELN. Armed with resources from oil, the ELN grew from roughly 350 fighters in 1984 to more than 5,000 fighters in 2000 with a presence in over 33 per cent of Colombian territory. Likewise, the FARC expanded from just 3,600 fighters in 1986 to over 18,000 combatants in 2004 with a presence in 70 per cent of Colombian territory. The FARC depended almost exclusively on rents from illicit coca production in zones where cultivation took place. However, in other regions the FARC continued to engage in traditional resource extraction including extortion and kidnappings to an even greater extent than the ELN.

\footnotetext{
${ }^{37}$ Jaramillo, et al. 1989: 48-49
} 
Table 1.4, ELN Fighters and Territorial Control, 1974-1996 $6^{38}$

\begin{tabular}{|l|l|l|}
\hline Year & \% Territory & Fighters \\
\hline 1974 & & $>70$ \\
\hline 1978 & & 40 \\
\hline 1979 & & 500 \\
\hline 1984 & & 350 \\
\hline 1986 & $17 \%$ & 800 \\
\hline 1990 & $23 \%$ & 1,800 \\
\hline 1994 & $26 \%$ & 2,800 \\
\hline 1996 & $33 \%$ & $4-5,000$ \\
\hline 2000 & & $\begin{array}{l}5,000+ \\
(41 \text { fronts })\end{array}$ \\
\hline
\end{tabular}

Table 1.5, FARC Fronts and Fighters, 1964-199939

\begin{tabular}{|c|c|c|}
\hline Year & Fronts & Fighters \\
\hline 1964 & & 44 \\
\hline 1984 & 27 & \\
\hline 1986 & 32 & 3,600 \\
\hline 1989 & 44 & 13,200 \\
\hline 1995 & 60 & 7,000 \\
\hline 1999 & 60 & 18,000 \\
\hline
\end{tabular}

As the FARC and the ELN became militarily stronger, both organizations shifted from a defensive to an offensive strategy. Insurgent attacks on state forces, military bases, and police posts were daily occurrence during the 1990s. Data from the Center for Conflict Analysis (CERAC) shows that the lethality and scale of the Colombian conflict grew exponentially during the last decade of the twentieth century. The number of

\footnotetext{
${ }^{38}$ Richani 2002: 85, 87; Felbab-Brown 2009: 93; Sánchez and del Mar Palau 2006: 10; Medina 1997: 314; Currea-Lugo 2007: 103-104

${ }^{39}$ Richani 2002: 76, 74
} 
conflict-related deaths in Colombia increased from about 500 in 1988 to 3,500 in $2002 .{ }^{40}$ The majority of those killed were civilians. Moreover, most civilian deaths were not the result of combat between the state and insurgents, but rather the result of direct civilian targeting by insurgents, state forces, and especially paramilitary groups. ${ }^{41}$

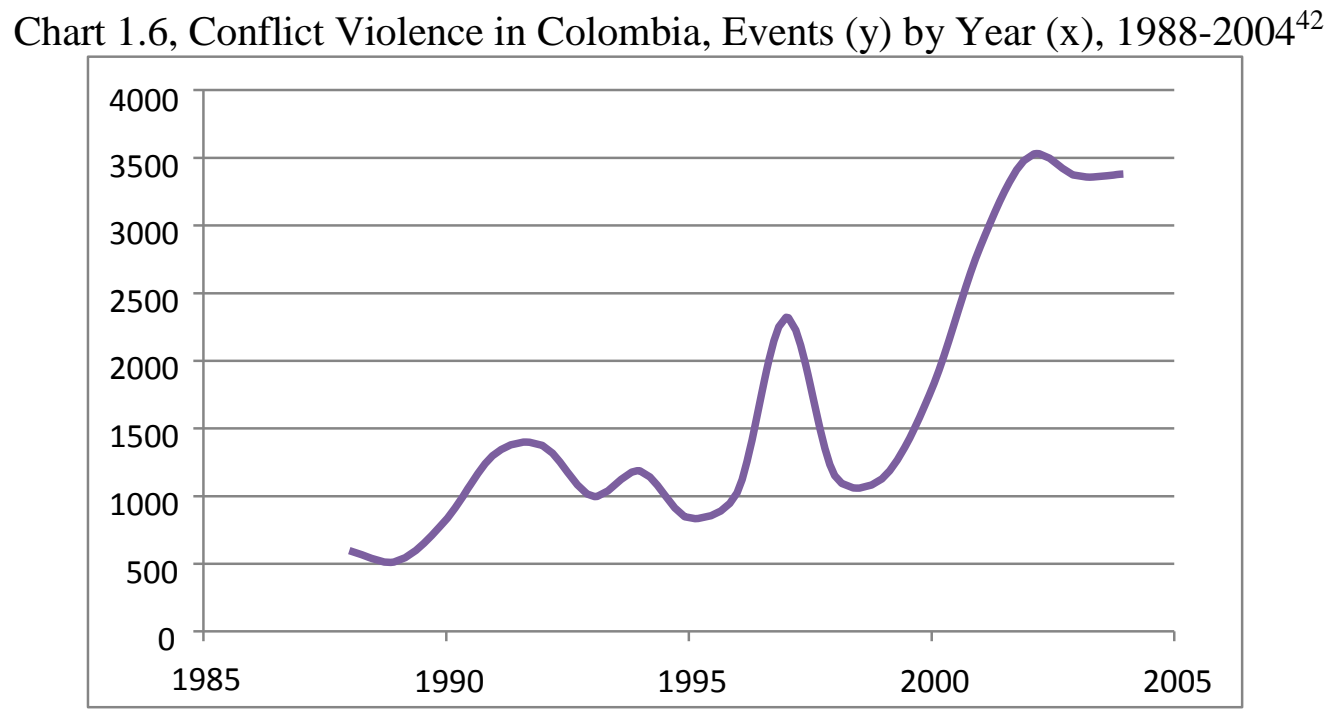

In sum, during the last two decades of the twentieth century commodity booms in oil and coca coincided with the territorial presence of the FARC and the ELN. Oil and coca provided insurgents with resources to build military strength and consolidate authority in their respective territories. Meanwhile, the state built up its own military capacity, in part with rents from the oil sector. The state also relied on paramilitary groups as a (unofficial) part of the counterinsurgent strategy. Paramilitaries formed in

${ }^{40}$ CERAC Colombian Armed Conflict Data Base

${ }^{41}$ Several right wing paramilitary groups formed in the early 1980 s as a result of insurgent extortion and kidnapping of rural elites. Backed by local coalitions of large landowners, drug traffickers, and the military, the paramilitaries were highly local, parochial movements until the movement consolidated under the United Self-Defense Forces of Colombia (AUC) in 1997.

${ }^{42}$ Resource Center for Conflict Analysis (CERAC) Colombian Armed Conflict Data Base. Note that CERAC data is not fixed. The database is an ongoing project and the data is subject to constant revisions and updates. 
more integrated regions of Colombia to resist insurgent control. As the paramilitaries gained strength, they moved into colonization zones. Indeed, all armed actors in the Colombian conflict competed for control over the territories with coca and oil. The state's success against insurgents in colonization zones varied according to the nature of insurgent authority. The most difficult battle was fought in regions with illicit drug production. There, the economic security of the civilian population became linked to insurgent control which impeded civilian cooperation with state forces.

\section{II. . The Puzzle: Commodity Booms and Insurgent Authority in Colombia}

Certainly, the presence of drugs and oil in areas under non-state control produced tremendous violence for Colombia. However, the problem of illicit drug production received far more attention from scholars and media outlets than the violence associated with the oil industry. National-level data showed a strong, positive correlation between illicit drug cultivation and violence in Colombia, since both increased in tandem during the 1980 s and 1990s. ${ }^{43}$ The most widely accepted theory to account for the cocaviolence correlation posited that access to illicit rents had transformed the insurgents into greedy and predatory narcoterrorists who did not hesitate to use violence in order to maximize drug profits. $^{41}$

The view that Colombian insurgents had become narcoterrorists dominated policy circles in Colombia and the United States for three decades. It was largely supported by academic studies. Greed theories of civil war emerged during the 1990s, lending support to the narcoterrorist thesis. Scholars such as Paul Collier, Chris Cramer, and Phillipe Le

\footnotetext{
${ }^{43}$ Angrist and Kugler 2005; Bergquist, Peñaranda, Sánchez 2001
}

${ }^{41}$ Ehrenfeld, 1992; Kaldor 1999; Dishman 2001 
Billion argued that natural resources, including drugs, diamonds, oil and timber, caused greed-based wars where participation was driven by the profitability of violence. ${ }^{44}$ In Colombia, the image of the narcoterrorist resulted in an interlinking of counterinsurgent and drug war policies because it was assumed that undermining illicit drug production would eliminate the insurgents' raison d'être. ${ }^{45}$ The cornerstone of the counterinsurgent policy in coca-growing regions was forced eradication of coca crops.

The theory of narcoterrorism and the attendant forced eradication program were counterproductive. Instead of weakening the insurgents, forced eradication of coca actually increased popular support for them, especially the FARC, in regions with illicit drug production. ${ }^{46}$ The problem was a misreading of the data. The correlation between illicit coca cultivation and violence was strong at the national level, but did not hold at the local level. To the contrary, sub-national analyses suggested that the presence of coca did not correlate with increased insurgent violence against civilians. In fact, subnational data instead revealed that oil was responsible for a good share of the violence. The regions where oil was extracted were some of the most violent places in Colombia.

\section{Coca and Insurgency}

At the department level, Holmes, Gutiérrez and Curtin find no relationship between the size of the area of coca cultivation and insurgent human rights violations in Colombia, including homicides, disappearances, massacres, and kidnapping. In fact, Holmes, et al. find that insurgent violence was relatively low in Caquetá and Guaviare,

${ }^{44}$ Collier, et al. 2003; Cramer 2002; Le Billion 2001

${ }^{45}$ Felbab-Brown 2009

${ }^{46}$ ibid 
the two Colombian departments with the largest area of illicit crops, and began to increase only after illicit cultivation significantly decreased in the late $1990 \mathrm{~s} .{ }^{47}$ What is more, the homicide rates of the three coca producing departments of Caquetá, Putumayo, and Guaviare are, on average, lower than in other departments without significant coca cultivation.

Chart 1.7, Homicide Rates in Coca and Non-Coca Colombian Regions, 1985-94 ${ }^{48}$

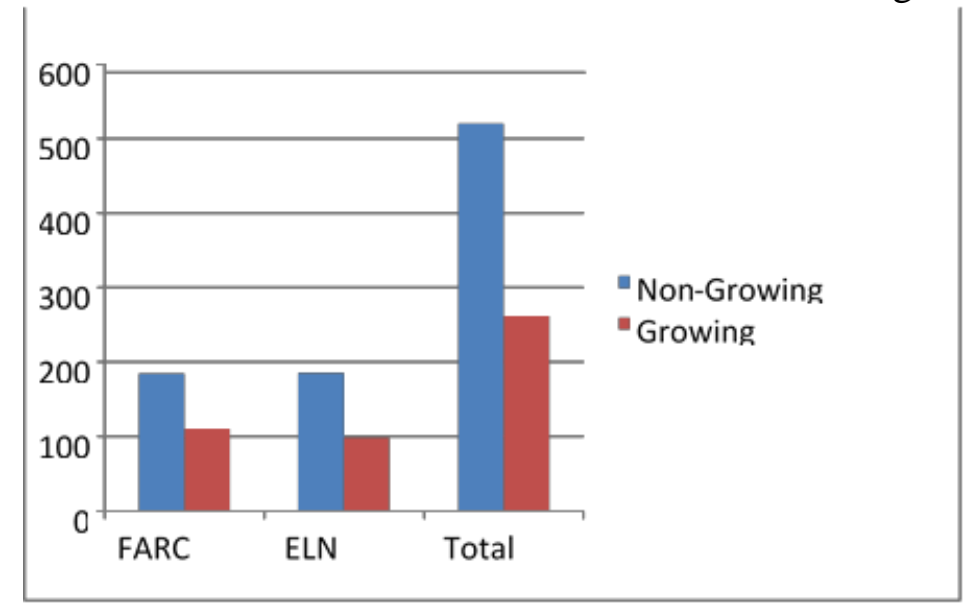

Consistent with Holmes, et al.'s findings, the aggregate homicide rate in the nine departments with significant coca cultivation in 1993 was lower than the homicide rate in the 19 departments with no coca cultivation. This is the case even if we leave out of the analysis the three departments with major urban centers: Bogotá, Medellín, and Cali. ${ }^{49}$ Hence, the evidence suggest insurgents prey less on civilians in regions where coca is cultivated. The finding is even more significant if we consider that the FARC occupied the coca-growing departments with its largest insurgent fronts. It is perplexing that the

\footnotetext{
${ }^{47}$ Holmes et al. 2008, 2009. The decrease in coca cultivation was mainly due to forced eradication under Plan Colombia, a 1999 joint U.S.-Colombian effort to undermine the drug trade and defeat insurgents.

${ }^{48}$ Angrist and Kugler 2008:197

${ }^{49}$ ibid
} 
Colombian departments with the largest insurgent presence, thriving criminal economies, and constant movement of transient populations had lower homicide rates than more integrated regions of the country. Some form of order had prevailed in these regions which the narcoterrorism theory could not account for.

Chart 1.8, Insurgent Actions in Colombia, Coca and Oil Departments, 1985-1994 ${ }^{50}$

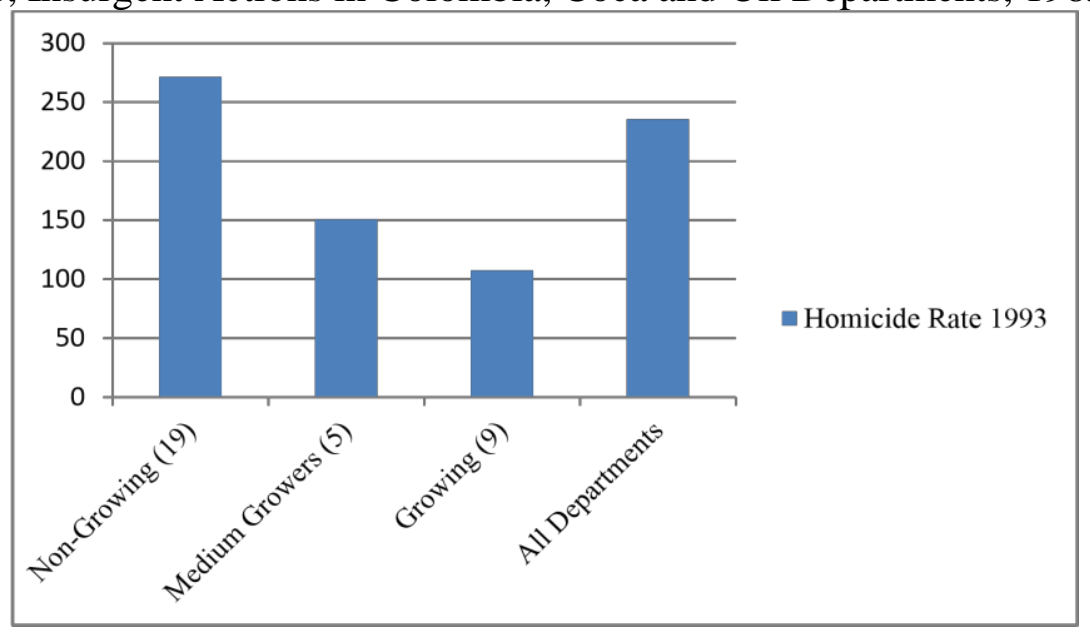

What accounts for lower levels of insurgent predation and homicides in cocaproducing regions? Numerous qualitative studies of the FARC and their relationship with civilians in Caquetá, Guaviare, and Putumayo, provide some important clues. Graciela Uribe and Juan Guillermo Ferro are two Colombian scholars who visited Caquetá in 1999 and interviewed FARC members, government officials, and the civilian population. They found that in Caquetá the FARC developed autonomous institutions through which the insurgents provided a range of public goods: security, criminal justice, resolution of land disputes, regulation of coca prices, and regulation of migration. Because of the

\footnotetext{
${ }^{50}$ I use Angrist and Kugler's (2008: 197) categories of growing and non-growing regions, combining growers and medium growers into one category. For insurgent activities, I use data provided by Fabio Sánchez at the Universidad Los Andes, which is compiled from the report Municipios y Regiones de Colombia, Una mirada desde la sociedad civil, Fundación Social 1998.
} 
effectiveness by which the FARC maintained order, local civilians assented to their authority, often contrasting the FARC's efficacy to the corruption and inefficiency of state institutions.

In addition, Ferro and Uribe found that in Caquetá the local communities credited the FARC with building roads, schools, and hospitals by providing resources to the local Community Action Boards. The FARC's authority in the region made it possible to earn a good income by cultivating coca in an environment of relative peace and order. In exchange, peasant cultivators, coca merchants, and narcotics traffickers consented to certain taxes and fees being imposed by the FARC. ${ }^{51}$ The same symbiotic relationship between insurgents and civilian populations is noted in other FARC-controlled regions with illicit cultivation including Miraflores, Guaviare, La Macarena, Meta, and Putumayo. $^{52}$

In addition to delivering order and security, the FARC also organized a peasant resistance to state repression. The FARC resolved collective action problems in the political organization and activism of peasant illicit producers. Based on her research in the Bajo Cauca region, Colombian anthropologist María Clamencía Ramírez finds that the FARC played a central role in organizing a 1996 protest in which some 200,000 illicit farmers challenged the state's policy of eradicating coca through aerial fumigation with glyphosate, a broad-spectrum herbicide. The FARC organized resources and protection, and promoted local participation in the protest. Participation in such a protest was high risk because it signaled one's involvement in illicit cultivation - a criminal activity.

${ }^{51}$ Ferro and Uribe 2002; also see Ferro 2004, Uribe 2001; Jaramillo et al. 1989

${ }^{52}$ Espinosa 2000, 2010; Molano 1987; Ramírez 2011 
However, participation in FARC-controlled regions was widespread. Moreover, the peasants won certain concessions from the state including infrastructural improvements and a delay in glyphosate spraying to allow for voluntary removal of coca plants. ${ }^{53}$

Vanda Felbab-Brown finds that because the FARC was so effective in delivering protection and order in coca-growing regions one could find the highest levels of popular support for insurgents in those areas. Felbab-Brown links peasant support for the FARC in coca-growing regions to the government's forced eradication campaign. She argues that government attacks combined with FARC protection essentially drove civilian populations into the arms of the insurgents. Peasant support was pragmatically based on economic and security interests. It had everything to do with the population's relationship with the state, but did not necessarily signal support for the FARC's revolutionary goals. $^{54}$

\section{Oil and Insurgents}

A very different dynamic is observed in regions with oil, though there is much less qualitative research to draw from. Government and media obsession with the narcoguerilla resulted in scholarly neglect of other commodities in Colombia that generated a great deal of violence. Dube and Vargas find that at the municipal level oil

prices are positively correlated with conflict-related violence. ${ }^{55}$ The finding suggests that violence is not driven by resource scarcity, but rather by greed. Between 1988 and 2001, the Colombian departments of Santander, Bolívar, and Antioquia registered the highest

\footnotetext{
${ }^{53}$ Ramírez 2011

${ }^{54}$ Felbab-Brown (2009) also finds that illicit cultivation coincides with higher levels of popular support for insurgents in Afghanistan and Peru.

${ }^{55}$ Dube and Vargas 2006
} 
number of human rights abuses by insurgent groups. ${ }^{56}$ All three departments were sites of significant oil and mineral (coal, gold, and emerald) extraction and transport. Of these departments, only Bolívar registered significant illicit crop cultivation. ${ }^{57}$ Further, Arauca and Casanare, the departments with the largest oil fields, registered the highest homicide rates during this period. ${ }^{58}$

Chart 1.9, Insurgent Actions in Oil Producing Departments of Colombia, 1985-1994 ${ }^{59}$

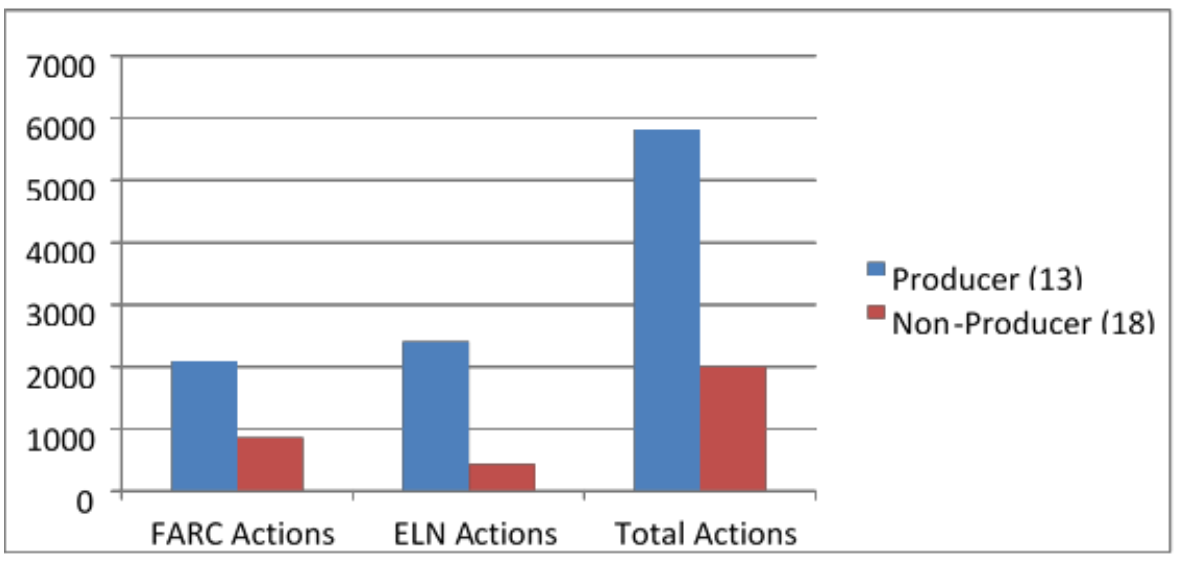

In Colombia all armed actors - including the state - have financed their military activities with revenues from oil. However, among non-state actors, the ELN was by far the most involved in exploiting the oil industry for the simple reason that oil extraction was concentrated in the ELN's rearguard territory in the Magdalena Medio and eastern plains. Indeed, after a devastating military defeat in 1973, the ELN reconstructed their

\footnotetext{
${ }^{56}$ Holmes, et al. 2008, 2009; Rangel 1998

57 Angrist and Kugler (2008) categorize Bolívar as a medium grower.

${ }^{58}$ Holmes and Gutiérrez de Piñeres 2012

${ }^{59}$ Ecopetrol; http://www.ecopetrol.com.co/contenido.aspx?catID=376\&conID=43160; data from Fabio Sánchez at the Universidad Los Andes; data compiled from the report (1998) Municipios y Regiones de Colombia, Una mirada desde la sociedad civil, Bogotá: Fundación Social
} 
organization almost entirely with rents obtained from extorting oil companies and their subcontractors in Arauca. The ELN started with ransom kidnappings and extortions, but then moved to attacking the oil infrastructure with dynamite in order to generate repair projects that they could control and extort for rents. Later, the ELN applied a similar strategy in Casanare. There, the Coveñas pipeline was attacked 911 times between 1986 and 2001 resulting in a cost of US\$141.2 million. In 1996 alone, 24 petroleum workers were kidnapped. ${ }^{60}$

The ELN justified violent attacks on the oil infrastructure with a nationalist discourse, declaring it their political objective to protect oil from foreign interests. However, the ELN did not succeed in constructing a political project around oil. ${ }^{61}$ The damages caused by ELN attacks on the oil infrastructure were carefully calculated, not just by the government and oil companies but also by the local community that surrounded the pipelines and also organized petroleum workers. The attacks cost local populations billions in repairs, spilt oil, production stoppages, environmental damage, and the human costs of using explosives near population centers. By 2003, the department of Arauca was economically insolvent, unable to pay even teachers' salaries, despite the tremendous oil wealth that flowed directly into local government coffers. As a result the ELN lost significant popular support. The insurgents continue to operate in the zone but as a predatory authority enforcing their interests on an unwilling population.

The ELN's predatory authority is captured by higher rates of violence which result from contestation and civilian-targeting. The ELN did not exercise legitimate

\footnotetext{
${ }^{60}$ Pearce 2005: 36

${ }^{61}$ Pearce 2005; Peñate 1998
} 
authority in the region, and hence sectors of the local population were available allies for the ELN's armed rivals including state forces, the FARC, and right-wing paramilitaries. The presence of armed rivals and civilian collusion with these actors generated a great deal of civilian-targeting by the ELN as well as other actors. Even the peasant sector that benefited from the ELN's influence over public expenditures was easily co-opted by alternative authorities, especially the FARC.

\section{Insurgent Authority: Concept and Operationalization}

Max Weber understood compliance on the part of subordinates as evidence of a ruler's legitimate authority. Having observed compliance in response to distinct types of authority from traditional to rational, Weber concluded that the legitimating principles of authority must vary from one society to the next in accordance with different value systems. ${ }^{62}$ Legitimate authority, according to Weber, was a question of culture. However, Weber's critics rightly point out that rulers can exact obedience even in the absence of legitimacy. Subjects comply because going against authority entails high risks. ${ }^{63}$ Legitimate authority is not a question of whether subjects obey, but rather whether obedience is based purely on coercion or involves consent.

The object of inquiry for my research is the different types of insurgent authority that develop in conflict zones with licit and illicit commodity production. I define authority as the power to create obligations to be obeyed. There are two types of authority. Predatory authority is the power to create obligations by coercion. Legitimate authority is the power to create obligations by consent.

\footnotetext{
${ }^{62}$ Weber 1958
}

${ }^{63}$ Scott 1992 
In Colombia, both the FARC and the ELN exercised de facto authority in their respective territories. Indeed, both insurgencies succeeded in collecting rents from local populations. However, only the FARC's authority approached the Weberian ideal of 'legitimate authority' in which compliance on the part of civilians is at least in part based on $a$ belief that power is being exercised justifiably. ${ }^{64}$ Meanwhile, the ELN's authority was predatory because compliance was based purely on coercion. Predatory insurgents impose their will on an unwilling society.

Figure 1.10, Concept Chart: Legitimate and Predatory Insurgency

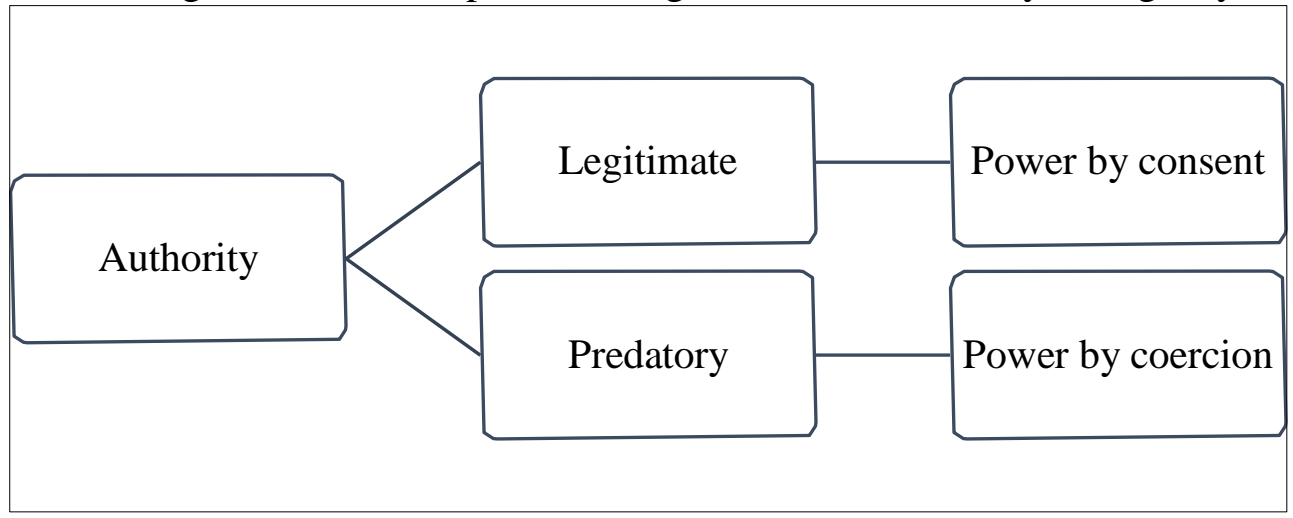

Distinguishing legitimate and predatory authority through observation is difficult because it requires moving beyond the open interactions between insurgents and civilians to observe civilians' 'hidden transcripts. ${ }^{65}$ As described by James Scott, subordinates reveal their true perceptions of authority in 'safe places' out of public view. When insurgent authority is predatory, hidden transcripts are sites where power is questioned and rejected. Subordinate resistance or revolution is a case in which hidden transcripts are

${ }^{64}$ Fabienne 2010

${ }^{65}$ Scott 1992 
acted out. In other words, hidden transcripts tell us if civilians obey because they consent to the authority or merely because they are coerced. ${ }^{66}$

Because hidden transcripts take place in sequestered spaces, as a researcher direct observation of predatory and legitimate authority is problematic. Therefore, for this research I operationalize the outcomes legitimate and predatory authority with two indirect, observable indicators of civilian beliefs about insurgent authority: voluntary participation and collaboration with enemies.

First, while most civilians will hand over part of their economic surplus to avoid insurgent violence, few will voluntary join an insurgent organization that demands rents unless the insurgents exercise legitimate authority. Hence voluntary participation in an insurgent organization that obligates rent payments is an indicator of legitimate authority. Participation can take two forms. First, civilians can directly participate as voluntary recruits. Second, civilians can indirectly participate by joining civil society organizations, or protests, or attending public events that are supported by or affiliated with the insurgents. I call this voluntary mobilization. High rates of voluntary recruitment and voluntary mobilization are observable indicators of legitimate authority. Conversely, low levels of recruitment, forced recruitment, defections, and mobilization against the insurgent group or their activities are indicators of predatory authority.

Second, all Colombian regions with oil and coca became targets of both military and paramilitary campaigns to undermine insurgent control. Between 1985 and 2007 there were almost constant military incursions into these zones by rival armed groups. In 
some instances civilians collaborated with rivals, taking high risks to undermine the insurgents' power within the community. Collaboration with rivals included providing information and material support. Because of the high risks involved, civilian collaboration with armed rivals of the insurgent authority is considered here an empirical indicator of predatory authority. Conversely, where civilians do not collaborate, or demonstrate loyalty to the insurgents I consider it an indicator of legitimate authority.

Figure 1.11, Operationalization of Insurgent Authority

\begin{tabular}{|c|c|}
\hline Indicators, Legitimate Authority & Indicators, Predatory Authority \\
\hline 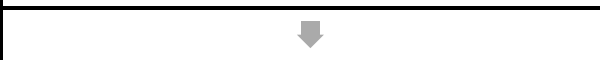 & $\bar{v}$ \\
\hline Participation & Participation \\
\hline $\begin{array}{l}\text { - voluntary recruitment; voluntary } \\
\text { mobilization }\end{array}$ & $\begin{array}{l}\text { - low/forced recruitment } \\
\text { - mobilization against insurgents }\end{array}$ \\
\hline$\nabla$ & $\sqrt{2}$ \\
\hline $\begin{array}{l}\text { Collaboration with enemies } \\
\text { - no information, no material } \\
\text { support }\end{array}$ & $\begin{array}{l}\text { Collaboration with enemies } \\
\text { - information and especially } \\
\text { material support }\end{array}$ \\
\hline
\end{tabular}

In most cases, the presence of lucrative commodities results in predatory insurgent authority. Only under certain conditions will civilian populations actually find it beneficial to hand over part of their economic surplus to insurgents. These conditions arise where states are either absent, repressive, or both. In the case of illicit commodity production, state policies that criminalize economic activity directly contribute to the development of legitimate insurgent authority. My research matters for policy makers precisely because I find that the state plays a central role in shaping the relationship between insurgents and civilian populations. 


\section{Why It Matters: The Practical and Theoretical Implications}

Why should we care about how different commodities shape conflict dynamics? Resources play a central role in contemporary intra-state wars. Today's insurgent and terrorist groups are largely self-financed, and most have links to transnational criminal networks, particularly the international drug trade. ${ }^{67}$ However, despite the importance of resources in shaping conflict, resources are marginal in political and academic approaches to the armed conflict in Colombia. Since the mid-1990s, Colombia's national security strategy has demonstrated little consideration for natural resource issues. By shedding light on the role of resources in conflict dynamics, my research addresses a contemporary security threat and a policy area where government response has been inadequate.

In particular, my research matters for policy questions surrounding conflicts that have coincided with illicit economies and black market activities, such as those in Colombia, Afghanistan, Burma, and Peru. For three decades, the narcoterrorism thesis has been the dominate discourse behind policy choices for these conflicts in particular, resulting in controversial and ineffective policies that target illicit cultivators and directly involve them in the hostilities in order to undermine insurgents. Such policies have been counterproductive to the war effort in such places as Colombia and Afghanistan since attacks on illicit cultivators only strengthen the symbiotic ties between the community and the insurgents that offer them protection. ${ }^{68}$

\footnotetext{
${ }^{67}$ Cornell 2005, 2007; Hutchinson and O’Malley 2007; Makarenko 2004

${ }^{68}$ see Felbab-Brown 2009
} 
My research also matters for counterinsurgent efforts in places where insurgents fund their activities by exploiting mineral resources, namely oil. Indeed, the obsession with combating illicit drugs, largely driven by the U.S. security agenda, has eclipsed research on the relationship between conflict and oil. Yet in 2008 one third of the world's civil wars took place in oil-producing countries. Michal Ross argues that the effects of oil on conflict are more pronounced and widespread than for other mineral resources because oil is a more valuable commodity that numerous producer countries depend on as a primary export. Many oil-producing countries have been engulfed by full-blown civil wars since the 1970s, including Colombia, Algeria, Sudan and Iraq. Meanwhile, other oil-producing countries face ongoing secessionist struggles surrounding the rights to oil, including Nigeria and southern Thailand. ${ }^{69}$

Beyond the practical value of this study for security policy, my research has theoretical value for conflict studies. The contribution to the study of conflict is twofold. First, I depart from previous analyses by focusing on the state's role in shaping the relationship between the production of primary export commodities and conflict dynamics. What sets illicit drug production apart is that it is an economic activity that takes place in violation of the social order constructed and defended by the central state. The state's role in repressing illicit markets creates an opportunity for insurgents to join with - rather than coerce - the local population into giving up part of the economic surplus. My work breaks with the foremost theories on resources and war dynamics by bringing in the state. While providing highly valuable theoretical insights, scholars such

${ }^{69}$ Ross 2008 
as Weinstein, Ross, and Le Billion focus almost exclusively on the intrinsic qualities of resources and make little mention of the state as a key actor. ${ }^{70}$ Despite the central role of states in shaping economic relations, government policy is conspicuously absent from the literature on resources and conflict.

Finally, my research offers an analysis of the specific effects of illicit resources distinct from other types of natural resource commodities, something that most existing research does not attempt to do. ${ }^{71}$ Illicit drugs tend to be lumped in with other natural resources, which is problematic because those states that are most prone to internal conflict tend to have large illegal sectors and hence the effects of illicitness need to be explored. In fact, Hoffman and Centeno estimate that between 40 and 50 per cent of the population of Latin America works in the informal sector, including small illegal enterprises, street selling, and service provisions that take place without protection from the state. ${ }^{72}$ It is also problematic because even a superficial analysis reveals that illicit resources have a different effect on conflict dynamics. If nothing else, illicit resources are available only to non-state actors and hence tend to increase the military strength of the state's armed rivals relative to the state. Conversely, licit resources can be taxed by all armed actors, and tend towards a greater parity between state and insurgent military strength. $^{73}$

\footnotetext{
${ }^{70}$ Weinstein 2007; Ross 2003; 2004; Le Billion 2001

${ }^{71}$ Cornell 2005, 2007

${ }^{72}$ Hoffman and Centeno 2003: 372; also see Bulmar-Thomas 2003, and Oxhorn 2009: 217

${ }^{73}$ Cornell 2005, 2007; Richani 2005
} 


\section{Conclusion and Thesis Plan}

The relationship between resources and conflict dynamics is well studied and yet still poorly understood. Rich in quantitative studies, the existing literature lacks qualitative studies on how the presence of resources shapes outcomes at the local level, where insurgents interact with civilian populations. In Colombia, a puzzling pattern emerges in that insurgents operating in areas with illicit commodity production that is criminalized by the state exercise legitimate authority with the consent of the population. Legitimate authority in areas with illicit commodity production contrasts with the modal outcome, predatory authority, in regions where insurgents encounter oil and other natural resources that are legally extracted and produced.

The objective of this chapter has been to describe the development of legitimate and predatory authority in Colombia by contrasting the cases of the FARC and the ELN in coca and oil producing regions. In the following chapter, I propose a theory to explain the different outcomes. My argument focuses on the state's response to licit and illicit commodity production as the main factor shaping how insurgents extract resources and the nature of insurgent authority. I also provide a description of the qualitative comparative method that I use to test my hypotheses in chapters three through six. Chapters three and four provide empirical evidence of the ELN's interactions with the oil industry in Arauca. Chapters five and six provide empirical evidence for the FARC's interactions with the coca economy in Caquetá. Finally, chapter seven concludes with policy implications and brief narratives on Nigeria, Peru, and Bolivia to probe the external validity of my arguments beyond the Colombian case. 


\section{Chapter Two War Commodities and Insurgent Authority}

According to popular wisdom, the production of illicit commodities such as drugs during internal conflicts makes insurgents more violent toward civilian populations. ${ }^{1}$ After all, illicit drugs are highly lucrative and lootable, two commodity characteristics that are commonly linked to insurgent predation. ${ }^{2}$ However, in Colombia insurgents were less predatory in areas where illicit drugs were cultivated. ${ }^{3}$ In fact, as the previous chapter demonstrates, in areas with illicit commodity production FARC insurgents cultivated strong relations with local populations by providing public goods in exchange for access to part of the producers' incomes from illicit activities. With this chapter, I propose a theory to explain the link between illicitness and insurgent authority. I argue that state repression of illicit commodity production was the primary factor shaping opportunities for insurgents to bargain with public goods as an economic strategy.

My explanatory model begins with commodity type as the independent variable. My research is limited to only a subset of commodities that I call war commodities which are sufficiently lucrative and accessible to be a significant source of rents for insurgent groups. I divide war commodities into two broad types: licit and illicit. The two types

\footnotetext{
${ }^{1}$ Kaldor 1999; Dishman 2001

${ }^{2}$ Weinstein 2007; Collier, et al. 2003; Ross 2003, 2004

${ }^{3}$ Felbab-Brown 2009
} 
differ in terms of state policies that permit, protect, and encourage production and marketing of the former and repress the latter.

The state's choice to repress certain commodities is based on multiple factors. In Colombia, the policy came directly from the executive office with unanimous support from the country's political elite. A comparison of the coca-producing countries of Colombia, Peru, and Bolivia suggest that in Colombia coca is prohibited as a result of three key factors. First, coca is a source of power for criminal elites that threatened the existing order in Colombia. Second, coca production is a source of conflict with foreign governments in countries where drugs are consumed. Third, Colombia's coca producers are too organizationally weak to resist state repression.

Once the Colombian government made coca production illegal, I argue that state repression is the key mechanism linking illicitness to the development of legitimate insurgent authority. State repression threatens the economic security of illicit producers, thereby creating a space for insurgents to capitalize on insecurity by providing protection in exchange for a share of the profit. Populations that produce illicit drugs are better off under insurgent authority, even while losing part of their economic surplus. They will consent to the insurgents' imposed order, infusing insurgent authority with legitimacy. In comparison, state protection of other war commodities such as oil precludes cooperative exchanges between producers and insurgents resulting in the modal outcome. Insurgents rely on coercion to access rents and in so doing they become a predatory authority. 
Diagram 2.1, Summary of the Argument

\begin{tabular}{|c|c|}
\hline \multicolumn{2}{|c|}{ Commodity Type } \\
\hline Illicit & Licit \\
\hline & \\
\hline \multicolumn{2}{|c|}{ Economic Strategy } \\
\hline Coercion & Cooperation \\
\hline \multicolumn{2}{|c|}{5} \\
\hline \multicolumn{2}{|c|}{ Authority Type } \\
\hline Predatory & Legitimate \\
\hline
\end{tabular}

This chapter is divided into four parts. First, I provide the groundwork including the scope conditions, assumptions, and main actors in my argument. Part II contains the core material of the chapter. There, I develop my explanatory model beginning with the independent variable, commodity type, and ending with the outcome insurgent authority. Part III considers organizational structure and resource accessibility as two rival hypotheses, using evidence from Colombia to demonstrate the theoretical value of my research. Finally, Part IV provides a description of the methodology used to identify my case studies and test my claims with a sub-national level qualitative comparison of two Colombian regions.

\section{Scope Conditions, Actors, Assumptions}

\section{Scope Conditions}

The explanatory model that I develop with this research is tested with empirical evidence from Colombia. However, the causal logic and predictions should hold for other conflict settings with insurgent groups that fall within a set of scope conditions. There are four conditions that define the explanatory boundaries of the arguments presented here. Namely, my arguments apply where insurgents are organizationally 
autonomous, politically motivated, and dependent on local populations for resources, and operate in frontier zones where state capacity is relatively low. These scope conditions do not exclude the majority of the cases of rural insurgency since the end of the Cold War. Beyond Colombia, my arguments are applicable to insurgent groups operating in Peru, Afghanistan, Burma, Angola, Nigeria, and Sudan, to name a few. However, the purpose of the scope conditions are to distinguish these cases of contemporary rural insurgency - to which my arguments apply - from other types of armed actors beyond the scope of the study such as Cold War insurgencies that were wholly funded by foreign governments, urban insurgencies, paramilitaries, civilian militias, and criminal organizations.

First, some armed actors such as paramilitaries and most civilian militias fall outside the scope of this research because they are not organizationally autonomous, and hence are an appendage of the state's security apparatus. These organizations will interact with civilians differently from insurgents that have no formal ties to the state because they don't necessarily articulate any social interests, and certainly do not depend on popular support. Autonomous organizations are social movements that emerge from civil society to express a social grievance(s) and to use violence to contest political power. Autonomous insurgents include national insurgencies such as the FARC and ELN in Colombia and the Shining Path in Peru, or transnational terrorist organizations such as Al Qaeda or Hezbollah.

A second scope condition limits the generalizability of my argument to insurgents that depend on local populations not just for political support and recruits but 
also for resources to wage war. An insurgent group might receive external support, but if at least part of their resources come from rent-seeking activities vis-à-vis local populations then the condition is met. This scope condition is based on existing research that shows that insurgents with sufficient external support interact with civilians differently because they do not have to strategize to extract resources while maintaining a social support base. ${ }^{4}$ In contrast, insurgents that depend on local resources are constantly looking for ways to tap the surplus production of the local population. My argument is about how insurgents sometimes develop strong, mutually beneficial relations with populations that they depend on for resources. Therefore, it cannot apply where the economically dependent relationship does not exist.

This scope condition is not a very restrictive one because most contemporary insurgents depend on rent-seeking activities to endure. The end of the Cold War and the terrorist attacks of September 11, 2001, together caused a steep decline in external support for insurgent and terrorist organizations. After 1990, great powers stopped backing non-state allies in foreign countries, and the attacks of September 11, 2001, resulted in a crackdown on international funding for terrorist organizations. Hence, during the 1990s resources began to play a prominent role in determining the territories and populations that were the objects of war. ${ }^{5}$ The change in part explains the predominance of economic theories of civil war during that decade. Insurgent dependence on local population for resources coincided with an increase in insurgent

\footnotetext{
${ }^{4}$ Lidow 2010

${ }^{5}$ Le Billion 2005, 2007; Collier and Hoeffler 2005; Cramer 2002
} 
violence against civilians and stronger ties between insurgents and criminal organizations. ${ }^{6}$ Indeed, in most cases the presence of lucrative resources resulted in more predatory insurgents at the local level. Illicit drugs were an exception to that rule.

My third scope condition confines my arguments to insurgents that are engaged in organized violence with some political motivations, or "...a desire, conscious or unconscious, to obtain or maintain political power,"7 The intention here is not to limit the pool of potential cases to insurgents with purely political motives because there is hardly an empirical case of such a 'pure' insurgent organization. The condition is meant merely to distinguish insurgents with political goals (and perhaps also economic goals) from criminal organizations that engage in violence solely for profits. The distinction is important because in Colombia, and in Latin America more generally, criminal organizations and gangs operate in many contexts alongside insurgents, but their interactions with civilians are not limited by the same concerns for popular support. My argument assumes that insurgents care about civilian support, and will therefore prefer a less violent economic strategy. The assumption does not necessarily hold for criminal actors.

Finally, my arguments pertain to insurgents operating in rural areas or 'frontiers' where state capacity is weak, at least at the onset of commodity production. In general, low state capacity can be captured by the a low number of police posts, schools, roads, and hospitals per capita relative to the national average. In addition, low state capacity is

\footnotetext{
${ }^{6}$ Collier et al. 2003; Kaldor 1999; Dishman 2001

${ }^{7}$ Moser and Clark 2001: 14
} 
indicated by a lower percentage of homes with access to basic services such as running water, sewage, and electricity relative to the national average. Most contemporary rural insurgencies in the post-colonial world fit safely within this scope condition. Indeed, a major factor that contributes to the emergence and survival of insurgents is the weak presence of the state, which allows militant organizations to take advantage of rough terrain and local knowledge in order to elude the state. ${ }^{8}$

\section{The Actors: States, Insurgents, and Civilians}

My explanatory model theorizes about the interactions that take place among three key actors: the state, insurgents, and the civilian populations that inhabit the territories where insurgency and commodity production coincide. The logic of my argument rests on explicit definitions of the actors and their interests and preferences. At a basic level, I assume all actors to be rational, utility maximizing agents. Hence, my argument assumes that ideational and cultural factors are not significant determinants of behavioral outcomes and strategies.

First, I define the state as the armed organization externally recognized by the international community as the legitimate sovereign authority within a defined territory. I emphasis the external legitimacy of state power because in the context of internal conflict the state might not exercise legitimate authority in all of the national territory and among all social sectors, nor even 'monopolize the legitimate use of force.' As Michael Mann points out, "Most historic states have not possessed a monopoly of

\footnotetext{
${ }^{8}$ Fearon and Laitin 2003

${ }^{9}$ Weber 1958
} 
organized military force and many have not claimed it." ${ }^{10}$ By definition, internal conflicts emerge where sectors of civil society challenge state claims to legitimacy. Hence, what distinguishes the state from non-state armed actors that challenge state sovereignty is merely that state authority is externally legitimate. ${ }^{11}$

Second, I consider the civilian population to be the inhabitants of the region in which insurgents and commodity production collide and who are not members of any of the armed groups. ${ }^{12}$ In other words, civilians are all actors in the area under study that are not direct participants in the conflict. I consider civilians who regularly collaborate with insurgents as part of the civilian population. However, unarmed part-timers or political militants under the command of the insurgent military hierarchy are insurgents, not civilians.

For this research, I conceptualize civilians as agents pursuing autonomous interests in the context of war. The interaction between insurgents and civilians is indeed a two-sided interaction. The majority of research on insurgency characterizes civilians as passive targets of warring factions ${ }^{13}$. However, new research appropriately redefines civilians as agents in their own right that strategically pursue their autonomous interest vis-à-vis armed actors in the context of an internal war ${ }^{14}$.

\footnotetext{
${ }^{10}$ Mann 1986: 11

${ }^{11}$ The international community is a source of external aid and military support (not available to non-state actors) for states to defend against threats to sovereignty which can result in the perpetuation of civil war or 'never-ending wars'; see Hironaka 2005.

${ }^{12}$ Kalyvas 2006: 19

${ }^{13}$ Humphreys and Weinstein 2006; Weinstein 2007; Metelits 2010

${ }^{14}$ Kalyvas 2006: Kaplan (2012)
} 
Certainly, civilians are instrumental in their interactions with insurgent organizations and the state. Although the point is debated, the majority of studies show that civilian loyalty to one or another armed authority is determined by civilians' economic and security interests rather than moral or ideological affinity. ${ }^{15}$ For example, Stathis Kalyvas found that during the Greek civil war civilians took advantage of contestation between the state and insurgents to resolve personal vendettas by denouncing neighbors and even family members as enemy collaborators. ${ }^{24}$ Further, Wickham-Crowley argues that civilians will support insurgents that effectively provide a military defense, maintain order, and create economic security. However, when insurgents fail to meet these obligations, their authority becomes predatory and civilian support can more easily be won over by the state. ${ }^{25}$

In civil war we find countless examples of civilians 'switching sides' simply because the other side better served their interests. For example, in Peru the armed forces defeated the Shining Path insurgency by offering real political benefits to their peasant supporters. ${ }^{16}$ In Colombia, insurgents and their right wing paramilitary rivals actually recruited from the very same peasant populations, and insurgent combatants regularly 'switched sides' because the paramilitaries offered salaries and other benefits, such as family visits, which were prohibited by the insurgents. ${ }^{17}$

Third, I define insurgent organizations as non-state armed actors that collectively engage in violent contentious politics vis-à-vis the state. Contentious politics is defined as

\footnotetext{
${ }^{15}$ For example, Elizabeth Woods (2003) makes a strong case that civilian support for insurgents in El Salvador was based on moral considerations of the justness of the insurgent cause.

${ }^{16}$ Kay 2007: 7

${ }^{17}$ Guttiérrez 2008; Arjona and Kalyvas 2009
} 
"interactions in which actors make claims bearing on someone else's interest, in which governments appear either as targets, initiators of claims, or third parties." 18 Insurgents articulate the political grievances of some sector(s) of civil society, and engage in violence as a means to bring about political change. Hence, the purpose of organized violence is political change and resource extraction is therefore a means to an end and not an end in itself. When economic goals take over, the group crosses the line from insurgent to criminal organization.

I consider members of an insurgent organizations to be armed and unarmed political militants under the direct command of the insurgent military hierarchy as well as armed combatants. In many (though not all) instances members wear uniforms or some other visible indicator to distinguish them from the civilian population. Distinguishing FARC combatants from other actors is rather straightforward since the FARC is an organization in which all members have a place within the military hierarchy as armed and uniformed combatants. However, the membership of the ELN is less clearly defined. For a long time, the ELN operated by embedding members within legal civil society organizations and political movements. Hence, while some ELN members were armed and uniformed combatants, many others were unarmed political militants.

Finally, one critical assumption underlying my argument is that insurgents prefer strategies that limit the use of violence against civilians whose support is paramount to achieving political goals. Classic theories of guerilla warfare espoused by legendary

${ }^{18}$ Tilly 2003: 5 
revolutionaries such as Mao Zedong and Ernesto Che Guevara consider the support of the population to be the most critical tool for waging war. ${ }^{19}$ Vanda Felbab-Brown's more recent work demonstrates the continued importance of popular support or 'political capital' for insurgent organizations. She finds that political capital is perhaps more important than economic and military power for waging a successful revolution. ${ }^{20}$ Indeed, in almost all instances of civil war the state is militarily superior to insurgents and therefore insurgents need the support of at least one sector of the local population in order to resist the state. Fearon and Laitin identify civilian cooperation as a condition that ‘favors insurgency' precisely because civilians are a source of resources, recruits, and cooperation in avoiding state forces. ${ }^{21}$ Since violence against civilians undermines popular support, insurgent leaders will always prefer less violent strategies for extracting resources.

\section{The Argument}

My explanatory model tells a story about the interactions among states, insurgents, and civilian populations in conflict regions with lucrative and accessible war commodities. I begin with the independent variable, the type of war commodity. War commodities can be grouped into two discrete classes: licit and illicit commodities. Illicit commodities are illegal and therefore not a source of revenue for the state. In contrast to illicit commodities, licit war commodities are legal, and are in most cases an important source of government revenue. For this reason, states militarily protect licit commodity

\footnotetext{
${ }^{19}$ Tse-tung 2009; Guevara 2013; also see Wickham-Crowley 1986, 1987, and Woods 2003

${ }^{20}$ Felbab-Brown 2009

${ }^{21}$ Fearon and Laitin (2003)
} 
production in the context of an internal conflict. In particular, lucrative natural resources such as oil receive the highest level of state protection. Insurgents respond with different economic strategies.

Insurgent economic strategy is the intervening variable in my explanatory model. I argue that when the state, when it represses illicit commodities, contributes to the economic insecurity of populations engaged in illicit production. What is more, the state excludes that part of their territory from the state's provision of justice and order. This creates space for insurgents to benefit from a cooperative economic strategy accessing rents by offering protection and security. By deploying these goods, insurgents acquire resources and populations can produce illicit commodities under less risky conditions. The result is legitimate authority based on consensus.

Conversely, state protection of licit commodities ensures the economic security of populations engaged in or dependent on licit commodity production. The state incorporates these populations by using military force and providing security to protect their interests. In other words, the state builds a coalition with licit commodity producers which precludes cooperative exchanges with insurgents. Producers of licit commodities resist insurgent resource extraction leaving insurgents to follow a coercive economic strategy whereby resources are collected with the threat of violence. The coercive strategy generates rents for insurgents at the expense of the local population. The result is predatory authority or authority based on coercion. 
Diagram 2.2, Summary of the Argument with Causal Mechanisms

\begin{tabular}{|c|c|}
\hline \multicolumn{2}{|c|}{ Commodity Type } \\
\hline Illicit & Licit \\
\hline State Repression-exclude & Cooperation \\
\hline Coercion \\
\hline Economic Strategy Protection-incorporate \\
\hline Predatory \\
\hline \multicolumn{2}{|c|}{ Authority Type } \\
\hline & \multicolumn{2}{c}{ Legitimate } \\
\hline
\end{tabular}

\section{Independent Variable: Commodity Type}

For my argument, the type of war commodity is the causal variable that explains different insurgent authorities. War commodities are a subset of commodities commonly associated with internal war because they are both lucrative and accessible and therefore a good source of rents for militant groups. Most war commodities are natural resources. The four most common commodities associated with prolonged internal conflict are drugs, diamonds, oil, and timber. ${ }^{22}$ Paul Collier and Michael Ross argue that the presence of these natural resources constitutes a 'resource curse' that leads to unrestrained rent-seeking by insurgents thereby increasing the scale and duration of internal war. ${ }^{23}$ Moving the analysis to the local level, I argue that different types of war commodities have different effects.

22 Ross 2004; Le Billon 2001; Collier and Hoeffler 1999; Collier, et al. 2003

${ }^{23}$ Collier, et al. 2003; Ross 2003, 2004 
Rather than group war commodities together, I distinguish two discreet categories of war commodities: licit and illicit. Assignment to one category is politically determined as a matter of government policy. Licit commodities are legal and part of the formal economy. The state can levy taxes on the production of licit war commodities. Further, because war commodities are by definition highly lucrative, the state generates more revenue from war commodity production than in the case of other, less profitable economic activities. Hence, the state has a strong interest in protecting licit war commodities and incorporating the population sectors that produce them. In practice, state protection includes providing military security, maintaining order, and providing economic security through favorable contracts and regulation.

Conversely illicit commodities are, by definition, illegal and part of an informal shadow economy that operates outside the sphere of government control. The state cannot levy taxes on illicit commodity production, and nor can it regulate the illicit economy. ${ }^{24}$ However, enemies of the state can profit from illicit commodities, and use the revenues to undermine state institutions. Hence, states have a strong interest in repressing illicit war commodities and excluding the population sectors that produce them.

States repress illicit commodity production by sending in the state security apparatus - both military and police - to persecute illicit commodity producers, and to forcibly destroy the illicit commodity and the infrastructure and networks that make up

\footnotetext{
${ }^{24}$ Guáqueta 2003
} 
the illicit market. In Colombia, the state attacked illicit cultivation mainly with forced eradication, including glyphosate spraying of illicit crops.

Diagram 2.3, Typology of War Commodities

\begin{tabular}{|c|c|c|}
\hline War Commodities & Licit & \multicolumn{1}{c|}{ Illicit } \\
\hline Definition & Legal; taxable by state & Illegal; not taxable by state \\
\hline State Interest & $\begin{array}{l}\text { Source of revenue to build } \\
\text { Security }\end{array}$ & $\begin{array}{l}\text { Threat to security; source } \\
\text { of revenue for armed rivals } \\
\text { and criminals }\end{array}$ \\
\hline State Response & Protect & Repress \\
\hline
\end{tabular}

\section{Illicitness as a Policy Choice}

Since the state forgoes the ability to tax production, the question of why governments prohibit certain economic activities in the first place is crucial. Indeed, among the three Andean nations that produce coca, Colombia is the only one to consistently maintain a prohibition on coca production, and has adopted the most repressive policies toward coca producers. Bolivia has been the least repressive. With the exception of a brief period during the late 1990s, Bolivia has mostly tolerated if not outright allowed coca production. Peru has experienced significant policy shifts from prohibition and eradication to toleration. A comparison of Colombian drug policy with that of neighboring Peru and Bolivia reveals that Colombia's prohibition resulted from a combination of factors including the presence of drug trafficking organizations within the national territory, external pressure from consumer countries to curtail the drug trade, and 
the capacity of illicit producers to resist state repression.

A critical factor that distinguishes Colombia from its coca-producing neighbors is that Colombia had drug trafficking organizations within its national territory. Coca cultivated in Peru and Bolivia was mostly sold to Colombian traffickers. This shaped Colombia's strong stance against drug production. Colombia's drug market was dominated by drug barons from within who emerged from urban shantytowns to wield considerable power. The most notorious baron, Pablo Escobar Gaviria, is known to the world as a terrorist, but is a hero to the poor of Medellín that benefited from the free housing, soccer fields, and other public works projects that Escobar provided. ${ }^{25}$ In 1982 , Escobar won a seat in Colombia's Chamber of Deputies, although the Chamber refused to allow Escobar to take his seat. ${ }^{26}$ Hence, despite the flow of drug money to certain corrupt politicians, the drug trade ultimately posed a serious threat to Colombia's political class as a whole. Targeting drug cultivators was one way the Colombian political class attempted to suppress a popular threat to their monopoly on political power.

In addition to the threat from drug cartels, Colombia was also under strong pressure from the United States to curb the production of drugs within its territory. As early as 1978 , the U.S. government began using a carrot and stick approach to push their drug war agenda in producer countries. After 1986, the United States stepped up its efforts to identify and punish 'uncooperative' supplier countries with its decertification program. At that point, rising cocaine consumption in the United States was being defined as a matter of national security. In 1997, the United States decertified Colombia

\footnotetext{
${ }^{25}$ Thompson 1996

${ }^{26}$ Hinojosa and Pérez-Liñán 2003: 67
} 
based on evidence that President Ernesto Samper had taken a campaign contribution from the Cali cartel. Subsequently Samper stepped up eradication efforts in order to demonstrate Colombia's commitment to combating drugs. The threat of decertification which implied trade sanctions and a loss of foreign assistance was a major factor in pressuring Colombia not only to prohibit coca cultivation, but also ensuring that the Colombian government would use its biggest weapons, including military force, to eradicate coca. $^{27}$

The same threat of U.S. decertification was the main factor behind Peru's decision to implement forced eradication in the Upper Huallaga Valley in 1978. However, in 1989 Peruvian President Alan Garcia rejected U.S. anti-drug aid and halted all eradication efforts in the Upper Huallaga Valley largely because it was seen as ineffective, but also because it proved counterproductive to the war effort. ${ }^{28}$ Ultimately, relations with the U.S. were remedied when President Alberto Fujimori agreed to cooperate in a new interdiction plan that targeted narcotics traffickers. In 1998 Bolivia began forcibly eradicating coca in response to a U.S. threat to decertify the Andean country for tolerating coca production. Forced eradication in Bolivia quickly ignited a rebellion of sorts on the part of Bolivia's well-organized indigenous coca-producing communities. Indeed, Bolivia demonstrates the third factor that shapes the state's choice to make the production of a commodity illegal: the organizational capacity of illicit producers to resist.

Of the three Andean nations that produce coca, Colombia's coca farmers are the

${ }^{27}$ Ayling 2005; Dion and Russler 2008

${ }^{28}$ McClintock 1988: 130-134; Felbab-Brown 2009: 50-55 
weakest in terms of organizational capacity and access to political power. Until the FARC stepped in to organize coca producers, these sectors could do little to resist state repression of their economic activities. In Peru, coca farmers are somewhat more organized because of their indigenous identity. In Bolivia coca is produced by organized, cohesive, politically active indigenous populations. In response to the government's 1998 eradication policy, Bolivia's coca farmers mobilized behind Juan Evo Morales Ayma and his Movement Toward Socialism (MAS) in opposition to the government of President Carlos Mesa. Bolivia was on the verge of civil war primarily over the question of indigenous rights to cultivate and sell coca. Eventually, President Mesa ended the eradication programs, lifted the ban on coca production, and resigned from office, as did his successor. In 2006, Evo Morales, a coca farmer, was elected President of Bolivia. ${ }^{29}$

The decision to make drug production illicit in Colombia is an executive decision that comes from the office of the president but with practically no opposition from Colombian legislators. Strong executives and rule by decree are common characteristics of Latin American democracy, and Colombian drug policy has been no exception. ${ }^{30}$ The Colombian government began forced eradication of coca crops in 1986 . While there have been some changes in the policy across time, the most important being the shift away from manual eradication to reliance on aerial spraying with glyphosate, the Colombian government has not wavered in its policy of prohibition nor its resolve to eliminate illicit crops. Indeed, even while the government has entertained and even implemented experimental alternative development programs mostly with European support, the

${ }^{29}$ Kurtz-Phalen 2005: 106

${ }^{30}$ O’Donnell 1994 
programs are never sufficiently funded and mostly rejected as futile efforts by politicians in Bogota. ${ }^{31}$

\section{The Role of the State}

By distinguishing war commodities based on their legality, the focus of my research shifts to the state and the role of policy in shaping conflict dynamics. Indeed, a central claim of this research is that the politics of commodity production is an important omitted variable that affects insurgent behavior, sometimes with unintentional consequences. From this perspective, the presence of a commodity will have a different effect on conflict in different political settings, or in response to changes in government policy such as decriminalization of illicit drug production.

Again, a comparison of Colombia with neighboring Peru and Bolivia demonstrates the point. Colombia has been the most repressive toward coca producers and as a result faced a robust insurgent organization with strong popular support in certain territories. In Peru insurgents were the strongest in coca-growing regions during periods of forced eradication, when they could bargain with illicit producers and win their support. $=$ Bolivia has mostly tolerated coca production, and has not been challenged by any rural insurgency.

Indeed, the cases of Bolivia and also Peru suggests that drug cultivation on its own does not necessarily generate opportunities for insurgents to profit and construct political power. Rather, what matters is the politics surrounding economic activity. In Colombia, the national government not only branded coca production as an illegal

\footnotetext{
${ }^{31}$ Vargas 2002: 18
} 
activity, but actively pursued and attacked illicit cultivators, threatening livelihoods while at the same time neglecting the security needs and harsh economic conditions facing the coca cultivating communities. These policies are largely responsible for the powerful alternative orders that insurgents constructed in Colombian regions with illicit drug production.

\section{$\underline{\text { Illicit Commodities and State Repression }}$}

When a commodity is dubbed illicit, the state's interest vis-à-vis its production is distinct from that towards licit commodities. Illicit commodity production is a source of revenue only for enemies of the state, and there is no incentive for the state to provide protection. At the same time, repression is costly, and the best policy might be nonenforcement.

The problem with non-enforcement is that illicit commodity production generates security threats not just by financing insurgents, but also because it can support the presence of powerful criminal organizations. This was certainly the case in Colombia where drug production in frontiers led to drug violence in core economic regions. During the 1990s, the Colombian state could barely respond to the epidemic of drug violence in the city of Medellín, a center of industrial activity and the second largest city in the country. Moreover, in the regions where illicit drugs are cultivated the state's authority is weakened and the result is violent crime and general disorder that works to further undermine central state control. ${ }^{32}$

\footnotetext{
${ }^{32}$ Chouvy 2006; Dion and Russler 2008
} 
In his now classic portrayal of agrarian societies, Robert Bates describes what markets look like in the absence of an overarching authority. The outcomes, he says, are a trade-off between wealth and security. Prosperity in the absence of government protection makes one the target of violence since there is no authority to protect life and property. The result is a 'security dilemma' comparable to an anarchic international environment in which states (individuals) defensively build security, but nonetheless resort to offensive violence because of uncertainty about the intentions of others. ${ }^{33}$ Collier provides a just description of ungoverned economic activity:

To see the centrality of government in resource extraction, consider what happens in its absence. How would natural assets be exploited in a lawless society that lacks any capacity for making or enforcing property rights over natural assets so that physical control of the asset is all that matters? ... If we imagine the population distinguished in the two dimensions of strength and luck, the natural assets are acquired disproportionately by those who are lucky and strong. Rent-seeking comes about because if ownership is conferred by physical control of territory, people will divert their effort into violence. Since violence can be offset by counter-violence, in equilibrium the value of the rents from the natural assets will be dissipated by the costs incurred by the violence. Inefficiency comes about because of the uncertainty as to whether control can be maintained in the future. ${ }^{34}$

Areas where illicit commodity production takes place emulate Bates' agrarian society. The law of 'might makes right' reigns and state legitimacy declines as the security dilemma deepens. State security forces make conditions worse by targeting illicit producers. What is more, criminals and insurgents thrive off illicit rents. ${ }^{35}$ Insurgents are one of many non-state armed actors that use illicit resources to challenge

\footnotetext{
${ }^{33}$ Bates 2001

${ }^{34}$ Collier 2010: 1118

${ }^{35}$ Cornell 2007: 209-210
} 
state sovereignty. Even where criminal organizations do not necessarily pose a threat, their activities do undercut internal order and compromise the state's capacity to govern. The Mexican government's war against drug cartels is a case in point. ${ }^{36}$ The cartels are not attempting to usurp political power, but their activities nonetheless impede effective governance.

Under these circumstances, the state ends up repressing the illicit economy. Hence, the state is absent as a source of order and security, but present as a predatory force. In this way, the political context surrounding resource production and exchange becomes one in which the local population is a target rather than a beneficiary of the state's provision of order, security, and military defense - three public goods that the state deploys to incorporate populations engaged in licit commodity production.

\section{$\underline{\text { Licit Commodities and State Protection }}$}

In contrast to illicit commodities, the state is central in the governance and protection of licit commodity production, especially natural resources such as mineral wealth and oil. As David Collier explains, "because they are natural, the ownership rights to these assets must be assigned socially: for practical purposes government has custodial rights on behalf of citizens who are collectively the owners." ${ }^{37}$

The most important characteristic of licit commodity production is that it generates rents for the state. In the case of war commodities, the revenue generated for the state is significant because the commodities are, by definition, lucrative. Hence, it is

\footnotetext{
${ }^{36}$ See Snyder and Durán-Martínez 2009

${ }^{37}$ Collier 2010: 1117
} 
in the national interest to protect licit war commodities, not only to keep them out of the hands of rebels, but also to secure the state's economic base. In order to protect sources of revenue, the state incorporates populations that produce licit commodities by deploying public goods. Public goods are non-excludable and non-rivalrous . The three basic public goods that states supply are military defense, internal order, and economic security. 38

The power of the modern state over civil society lies in its' organizational capacity to provide public goods. ${ }^{39}$ What is more, as the source of public goods the state exercises legitimate authority. However, contemporary insurgents also demonstrate the capacity to provide public goods and thereby supplant the state at the local level. In this scenario, the insurgent becomes the legitimate authority. I argue that insurgents have opportunity to become legitimate authorities when lucrative commodities are present and economic activity generates demands for public goods, but the state fails to incorporate the population.

\section{Intervening Variable: Economic Strategy}

Modern day insurgents are commonly compared to early state-builders in fourteenth and fifteenth century Western Europe that extracted resources to wage war. ${ }^{40}$ In both cases the actors are intent on building military power, but sometimes end up with centralized rule. Nonetheless, insurgent resource extraction is distinct from the activities of early state builders because it takes place in the shadow of a pre-existing state. Even

\footnotetext{
${ }^{38}$ Samuelson 1954: 387

${ }^{39}$ Tilly 2003, 2005; Mann 1985, 1986

${ }^{40}$ see Tilly 1992; Porter 2005
} 
where states govern poorly, government policies shape the interests of populations targeted by insurgents for resource extraction. ${ }^{41}$ State repression of illicit commodity production leaves excluded populations in a position to benefit from insurgent authority. Conversely, state protection of licit commodity production makes cooperating with insurgents a high risk activity. The interests and 'availability' of civilian populations shape insurgent economic strategies. Insurgents respond to excluded populations with cooperative strategies, but interact with other populations with a coercive strategy.

\section{$\underline{\text { Economic Strategies }}$}

I define insurgent economic strategy as the repertoire of activities through which insurgents interact with civilian populations for the purpose of accessing rents. I identify two types of insurgent economic strategy: coercive and cooperative. With a coercive economic strategy, insurgents extract resources using only the threat of violence. Civilians obey out of fear of punishment by insurgents. Hence coercion works like a racket. Conversely, a cooperative economic strategy entails an exchange. Insurgents extract resources and in return use their organizational capacity to provide public goods. The threat of coercion is still present with a cooperative strategy, but most civilians obey because the benefits of cooperation outweigh the loss of part of their productive output.

\section{$\underline{\text { Coercive Economic Strategy }}$}

I argue that in the presence of licit war commodities, insurgents coerce populations into paying rents. Coercion is needed because licit commodity production is protected and regulated by the state, and populations engaged in the production and

\footnotetext{
${ }^{41}$ Wickham-Crowley 1986
} 
marketing of licit commodities are incorporated into and benefit from the state's provision of public goods. Licit commodity producers stand to lose by cooperating with insurgents since their economic security is based on an exchange with the state. Hence, insurgents take resources by threatening violence.

Therefore, one defining feature of a coercive economic strategy is a transfer of the economic burden of war onto some sector(s) of the local population against their will. The tactics of a coercive strategy include ransom kidnappings and extortions as 'rackets' wherein targeted civilians or organizations pay rents to insurgents in order to avoid insurgent attacks. Tactics can also escalate to attacking economic infrastructure. In some cases, the coercive strategy includes payoffs to social supporters and political allies among the civilian population. As long as insurgents and their civilian supporters benefit at the expense of some other social sector, the strategy is a coercive one.

\section{Cooperative Economic Strategy}

In the presence of illicit commodity production, insurgents use a cooperative economic strategy. State repression and insecurity creates local demands for public goods. Indeed, while licit commodity producers are incorporated into the national project, illicit producers are excluded. Based on their exclusion, illicit producers will cooperate with an alternate authority (such as an insurgent organization) that can achieve collective goals even if it means that civilians will hand over a part of their economic surplus. Insurgents respond by offering public goods in exchange for rents. As a result, the population is incorporated into an alternative political project in which insurgents supplant the state's authority. 
The cornerstone of the cooperative strategy is expanding the benefits of insurgent resource extraction to include the local population. Above all, through insurgent resource extraction, illicit producers gain economic security. The tactics of a cooperative strategy include payment of protection rents in exchange for security from a third party (distinct from a protection racket) and economic regulation to protect prices. Protection rents are levied as taxes and fees that are agreed upon and fixed so that market actors can calculate their costs of production. It is not necessarily the case that all sectors of the local population pay rents to insurgents; rents may only be paid by illicit producers and merchants. Moreover, the amount paid may vary according to production such that wealthier producers and merchants pay more. Nonetheless, all sectors benefit from public goods and all are subject to the insurgents' imposition of rules and punishments in the maintenance of order.

\section{Dependent Variable: Insurgent Authority}

Political scientists such as Paul Collier, Jeremy Weinstein and Phillipe Le Billion have long argued that the presence of natural resources during internal conflict gives rise to predatory insurgents. ${ }^{42}$ Indeed, there is near consensus among conflict scholars that lucrative and accessible resources have a destabilizing effect on insurgent-civilian relations. However, I find that insurgents sometimes construct legitimate authority vis-àvis local populations through rent-seeking activities. The key variable determining whether insurgent authority will be predatory or legitimate is the type of war commodity. Insurgents access licit rents with a coercive strategy resulting in predatory authority.

${ }^{42}$ Collier, et al. 2003; Weinstein 2007; Le Billion 2000 
Likewise, insurgents access illicit rents with a cooperative strategy resulting in legitimate authority.

\section{$\underline{\text { Coercion and Predatory Authority }}$}

First, the presence of a licit war commodity results in predatory authority because insurgents use a coercive economic strategy that generates rents for them at the expense of the local population. For civilians, paying rents to insurgents is a loss. The only value is avoiding insurgent retribution. In this context, civilian interests conflict with those of insurgents, and insurgents have to impose their will on an unwilling population. Indeed, when insurgents use a coercive strategy they end up exercising predatory authority.

In Colombia, the ELN's strategy of stealing from wealthy oil multinationals won the insurgents international recognition as the 'Robin Hood' of Colombia. However, in the oil-rich department of Arauca the ELN's coercive strategy resulted in predatory authority precisely because the ELN and a small group of peasant supporters benefited at the expense of the community as a whole. As a result of the cost of ELN activities, popular support for insurgents declined and a powerful opposition formed. The political wing of the ELN demobilized and popular organizations that were once part of the ELN's social base publically condemned the insurgents' tactics. Eventually civilians resisted by collaborating with the state and right-wing paramilitary forces, resulting in violent contestation over territory. 


\section{Cooperation and Legitimate Authority}

Illicit war commodities lead to legitimate authority because insurgents use a cooperative economic strategy that generates rents for insurgents and also generates collectively beneficial goods. ${ }^{43}$ As Timothy Wickham-Crowley explains, insurgent authority is legitimated when it produces three basic goods: defense from external enemies, maintenance of internal order, and protection of the material security of the populace. ${ }^{44}$ These three activities are identical to the three activities of modern states identified by Charles Tilly. ${ }^{45}$ When insurgents deliver collective goods, civilians believe that insurgent rent collection is just or fair and that their interests are served by conceding to the insurgents' authority. The result is legitimate authority based on voluntary obedience.

The process by which insurgents come to exercise legitimate authority in the presence of illicit commodity parallels the development of modern states. In fact, the arguments I develop with this research are informed by the work of development scholars like Barrington Moore and Charles Tilly. Barrington Moore argues that centralized authority develops when a ruler employs superior organizational capacity to deliver defense, order and material security in exchange for part of the population's economic surplus. ${ }^{46}$ He argues that resource extraction can be more or less coercive, but in all cases resource extraction generates more power when based on cooperation. ${ }^{47}$ As Charles Tilly

\footnotetext{
${ }^{43}$ Parsons 1960: 199-225; Mann 1986: 7

${ }^{44}$ Wickham-Crowley 1987

45 Tilly 1992

${ }^{46}$ Moore 1978: 20-23

${ }^{47}$ Bakonyi and Stuvøy 2005
} 
explains, it was precisely in those regions of Western Europe where centralized rulers bargained with populations for resources that modern states first emerged. ${ }^{48}$ Likewise, I find that when insurgents deploy a more cooperative economic strategy they increase their power by constructing legitimating authority.

When insurgents exercise legitimate authority they begin to look like modern states. In Chapter six, I show that FARC insurgents exercised legitimate authority in the coca-producing region of Caquetá based on a cooperative economic strategy. If coca were a licit commodity, the FARC's project in Caquetá would be viewed as 'developmental' rather than criminal. ${ }^{49}$ Nazih Richani explains, "By providing market stability and protecting peasant coca plantations, FARC made it possible for the subsistence economy to incorporate into the international markets with minimum 'structural adjustment' and economic dislocations as opposed to the experience of peasants subjected to the market forces of the legal economy," ${ }^{50}$ As a result, support for the FARC was highest in regions with illicit cultivation. ${ }^{51}$ These regions also proved the most difficult for state forces and right-wing paramilitaries to reconquer.

\section{III: Alternative Explanations}

Over the past two decades, a large subfield of conflict studies emerged with the explicit purpose of explaining the effects of resources on insurgent behavior. Most of this work deals with the question of violence, concluding that lucrative resources make

\footnotetext{
48 Tilly 1985, 1992

${ }^{49}$ Developmental states pursue effective economic policies such as Japan, South Korea, and Taiwan in the latter part of the twentieth century; see Johnson 1982.

${ }^{50}$ Richani 2002: 71

${ }^{51}$ Felbab-Brown 2009; Ramírez 2011
} 
insurgents more predatory. ${ }^{52}$ Other studies focus on how resources influence conflict duration by sustaining insurgents and making war profitable. ${ }^{53}$ Very few analyses address insurgent strategy or territorial control as a function of resources. What is more, only a handful disaggregate distinct types of resources beyond identifying primary (natural) resources as the main drivers of conflict. Finally, practically no existing studies on resources and conflict explicitly address the distinct effects of illicit commodities.

Due to the lack of studies on illicit commodities and insurgency, there are few rival theories to account for the different types of insurgent authority that we find in Colombia. Nonetheless, the literature offers two theories on the causes of insurgent violence toward civilians that are applicable to my research question. The first theory looks at resources as causes. Jeremy Weinstein argues that variation in resource accessibility accounts for insurgent violence toward civilians. The second theory looks at organizational discipline and insurgent violence. Paul Staniland argues that organizational discipline makes insurgents less violent even in the context of lucrative resources. I evaluate the resource and organizational theory as explanations for the correlation between drugs and legitimate insurgent authority in Colombia. I find that neither theory sufficiently explains the relationship in light of the empirical evidence.

\section{$\underline{\text { Resource Accessibility }}$}

First, in a now classic study of resources and insurgent violence, Jeremy Weinstein argues that the accessibility of resources determines when insurgents will inflict violence on civilian populations in order to access rents. Weinstein reasons that

${ }^{52}$ Collier, et al. 2003; Weinstein 2007

${ }^{53}$ Collier and Hoeffler 2009; Ross 2004; Keen 1998 
insurgents with access to natural resources recruit with material incentives. The result is less committed, economically motivated combatants that are difficult to control and therefore more predatory toward civilians. ${ }^{54}$ Conversely, in the absence of lucrative resources insurgent leaders recruit only true believers that are less likely to prey on civilians. $^{55}$

Weinstein's theory can account for national level trends in Colombia. Certainly, illicit drugs are a highly accessible resource, and as drug production increased in Colombia insurgent violence also increased. However, at the local level Weinstein's theory falls short for two reasons. First, and most problematically, illicit drugs correlate with legitimate authority and lower levels of violence compared to oil. Yet oil is not an accessible resource. To the contrary, oil is quite difficult to loot. Oil requires a complex and expensive infrastructure to be transported from the point of extraction. And yet oil correlated with a great deal of violence in Colombian conflict zones. Second, Weinstein's predictions about insurgent recruitment are not validated by the empirical record in Colombia. There is no evidence that the FARC recruits by offering material rewards. In fact, after three decades of extracting wealth from the illicit economy, the FARC still does not offer their combatants salaries. ${ }^{56}$

\section{Organizational Discipline}

A second theory looks at organizational discipline as a variable that explains insurgent violence. Paul Staniland argues that organizational discipline defined as a high

\footnotetext{
${ }^{54}$ Weinstein 2007; also see Lidow 2010

${ }^{55}$ Weinstein 2007

${ }^{56}$ Gutiérrez 2006; Guáqueta 2003
} 
degree of internal, hierarchical control determines whether insurgent rent-seeking will involve violence toward civilians. Disciplined insurgencies are less likely to become violent in response to lucrative and accessible commodities. ${ }^{57}$

Organizational discipline can better account for insurgent behavior in Colombia. The FARC is certainly more disciplined than the ELN, and used less violence in extracting illicit rents than the ELN did in extracting oil. However, a more careful analysis reveals the limits of organization as an explanatory variable. If we compare the FARC and the ELN in interactions with the same commodity we find that the two insurgencies were similarly violent despite their distinct organizational structures.

In fact, the FARC extended its disciplined organization across the Colombian territory, but legitimate authority only developed in zones with significant illicit drug production. In other regions, the FARC surpassed the ELN in coercive rent-seeking, including extortions and kidnappings. In Arauca, the FARC attacked the oil industry alongside the ELN. ${ }^{58}$ In Hocol, Huila, a traditional stronghold of the FARC and an area of oil exploration, the FARC attacked the oil infrastructure three times, in 1992, 1999, and 2001 as part of a larger strategy to collect 'war taxes' from oil multinationals. In Hocol, the oil companies resisted and suffered violent consequences. ${ }^{59}$

Table 2.4, FARC and ELN Rent-Seeking Activities, 1998-199960

\begin{tabular}{|l|l|l|l|l|}
\hline Source & FARC & \% & ELN & \% \\
\hline Tax on Narcotics Traffickers & 180 & $40 \%$ & 30 & $20 \%$ \\
\hline
\end{tabular}

\footnotetext{
${ }^{57}$ Staniland 2012

58 Pearce 1995

${ }^{59}$ Pearce 2005: 37

${ }^{60}$ In millions with exchange rate $\$ 1=1,800$ pesos; Richani 2002: 64
} 


\begin{tabular}{|l|l|l|l|l|}
\hline Ransom-kidnapping/ Extortion & 198 & $44 \%$ & 40 & $27 \%$ \\
\hline Extorting Government Resources & 40 & $9 \%$ & 60 & $40 \%$ \\
\hline Assaults on Financial Institutions & 30 & $7 \%$ & 20 & $13 \%$ \\
\hline Total & 448 & $100 \%$ & 150 & $100 \%$ \\
\hline
\end{tabular}

Moreover, the case of the ELN suggests that organizational discipline is a result (rather than a cause) of resource extraction. The ELN evolved from a more or less centralized organization to a conglomerate of regional bosses or 'warlords' in large part because of the territorial specificity of oil. Oil royalties concentrated in municipal government coffers, and ELN fronts with access to oil rents became increasingly autonomous from the ELN national leadership. ${ }^{61}$

In sum, the Colombian case does not fit with either a resource accessibility or organizational discipline account of insurgent behavior. The presence of an accessible, illegal commodity did not increase insurgent predation. Likewise, FARC discipline did not preclude more violent forms of rent-seeking. I argue that a critical variable is omitted from these theories and from the conflict literature as a whole: the state. After two decades of research, it is hard to find even one study of resources and conflict that problematizes the role of the state. Ostensibly, this is because the presence of insurgents is taken to mean the absence of the state. But rarely is the state completely absent. Even where states are weak, state policies toward conflict regions still shape actor interests and insurgent-civilian interactions. Insurgent strategies are more than just a product of the

${ }^{61}$ Pizarro Leongómez 2011: 213, footnote 7 
resources they encounter or the organizational capacity that they bring. Strategies are also a reaction to the broader political environment in which the state is the dominant actor.

\section{Methodology}

In the following chapters I establish the validity of my arguments with a qualitative comparative case study analysis of the ELN and the FARC in the Colombia departments of Arauca and Caquetá. I selected the cases of Arauca and Caquetá using a method of difference (MOD) approach which calls for matching cases on all theoretically important variables except the explanatory variable. I then constructed narratives to link different commodity types to different types of insurgent authority. My analysis is based on two trips to the field for a total of six months of research in Colombia working in archives and conducting interviews. In the concluding chapter, I supplement my research with brief analyses of commodity production and insurgency in Peru, Bolivia, and Nigeria to test the generalizability of my argument beyond Colombia.

\section{Qualitative Comparative Analysis}

For this research, I use a qualitative comparative analysis (QCA) approach to validate my arguments. The QCA approach is a small-n research design that is holistic and theory-based. As an aspect of the holistic approach, QCA is case-oriented. The cases are well known and considered as a whole complex combination of properties. As a theory-based approach, QCA is deductive. The choice of causal variables, control variables, and cases is informed by theory. Traditionally, QCA is considered a macrocomparative approach that is applied to 'big questions' that call for comparison of entire societies, states or cultures. However, more recently QCA has been used to compare 
collective actors at lower levels of analysis including comparisons between social groups and even individuals. For this research, I work at the sub-national level, comparing two insurgent groups operating in two different Colombian departments. ${ }^{62}$

I chose the QCA approach for two reasons. First, the objective of my research was to test, with high validity, a theory about the causal relationship between different war commodities and insurgent authority. Hence, my goal was to identify casual variables and mechanisms that 'activate' the causal chain, and to offer a rigorous test of my causal story. ${ }^{63}$ QCA is a holistic and deductive approach that is ideal for testing causal processes with detailed narratives. Second, while a statistical analysis would test for a correlation between commodity type and insurgent authority across a broad set of cases, there are too few conflict-affected countries that produce illicit drugs to carry out a large-n analysis. ${ }^{64}$

\section{Causal Narrative}

In order to control for alternative hypotheses and lurking variables, I use a 'casual narrative' approach. A causal narrative is a method for tracing a process from an independent variable to the outcome via within-case analysis. ${ }^{65}$ The causal narrative allows for testing not only the presence or absence of key variables, but also for analyzing the preferences and intentions of actors to see whether behavioral outcomes follow the logic proposed by the theory. Again, my objective was to test for causal

\footnotetext{
${ }^{62}$ Berg-Schlosser, et al. 2009

${ }^{63}$ Munck 2004: 112; George and Bennett 2005:8; Ragin 2000: 12-13, 33,72

${ }^{64}$ There are four conflict countries that produce illicit drugs: Colombia, Peru, Afghanistan, and Burma.

${ }^{65}$ Mahoney and Rueschemeyer 2003: 36; Hall 2003: 384
} 
process and the chain of causality which requires identifying real actors behaving in ways and with the intentionality that my argument predicts.

\section{Sub-national Level Analysis and the MOD Approach}

My empirical research is based on a 'within case' or sub-national design. I chose this design in order to take advantage of built-in controls. My sub-national design allowed me to compare insurgents acting within the same conflict and policy environment but in two Colombian departments (or 'states' within a federalized structure) with different types of resources. ${ }^{66}$ To select my departmental cases, I used a method of difference (MOD) approach. MOD is done by matching all circumstances except the independent variable to provide some control over lurking variables ${ }^{67}$ Mill explains, "if an instance in which the phenomenon under investigation occurs, and an instance in which it does not occur, have every circumstance in common save one ... the circumstance in which alone the two instances differ, is the effect, or the cause, or an indispensable part of the cause, of the phenomenon,"

The advantage of this approach is that it provides a rigorous test for internal validity, or confidence that the outcome is attributable to the independent variable. Indeed, internal validity is obtained by controlling for, and thereby ruling out, rival hypotheses. The weakness of this approach is that there is not a strong test of external validity, or generalizability of the arguments to other conflict settings. To probe the

${ }^{66}$ Colombian is divided into 32 departments that are administrative sub-divisions of the state.

${ }^{67}$ Schutt 2009: 441

${ }^{68}$ Mill 1967: 391 
external validity of my argument, I include brief narratives of conflict and commodity production in Bolivia, Peru, and Nigeria in the concluding chapter.

Another limitation of the MOD approach it that it is impossible to find two Colombian departments that are identical in all aspects except the one causal variable, commodity type. Indeed, an observational study simply cannot provide the control that is achievable with an experimental design. Nonetheless, theory can inform method. Based on existing theories that offer potential rival theories, I can know which variables are likely to be correlated with my outcome of interest and I control for those variables in my selection of cases. In this way, some control is possible. I discuss some of the lurking variables below in describing my case selection. Of course, causal variables not yet explored by theory leave open the possibility of omitted variable bias.

\section{The Cases}

Using the MOD approach, I selected two insurgent-department cases that were comparable in all theoretically important factors except commodity type: the FARC in the department of Caquetá and the ELN in the department of Arauca. I relied on previous studies to determine control variables. In addition to commodity type, the conflict literature identifies three plausible explanatory variables: state capacity, organizational discipline, and social networks. ${ }^{69}$

First, Arauca and Caquetá are comparable in terms of state capacity at the time of the commodity booms in drugs and oil. Both departments make up part of the national territory but constitute marginalized frontiers with very low state presence. There was

\footnotetext{
${ }^{69}$ Fearon and Laitin 2003
} 
little economic activity in either department prior to drugs and oil with the exception of a handful of ranching exploits. Populations were detached from regional markets due to a lack of infrastructure. Both departments are colonization zones settled by peasants in the 1950s and 1960s. Finally, in Arauca and Caquetá the state deployed similar mechanisms for controlling the colonization process through civil society organizations including the Colombian Institute of Agrarian Reform (INCORA) and the Community Action Boards (JACs). ${ }^{70}$ However, over time local organizations, especially the JACs, became increasingly autonomous in both cases.

The second 'lurking variable' is organizational discipline. The FARC and the ELN would both be considered relatively disciplined insurgent organizations. During the time period under study, the FARC and the ELN were hierarchically structured with a clear chain of command and internal disciplinary codes. In fact, Fernando Cubides describes the FARC and the ELN as 'armed bureaucracies' that mimic each other in their strict military structure. ${ }^{71}$ Further, Camila Medina Arbeláez finds that demobilized FARC and ELN combatants report similar processes of socialization, behavioral codes, and internal discipline. ${ }^{72}$ Neither group pays salaries to the rank and file, and in both cases combatants are uniformed and separated from community and family in guerilla camps. Moreover, both groups follow a strict daily regimen of tasks and training.

Nevertheless, there is some variation between the two insurgent groups. During the 1980s the FARC began exhibiting greater levels of military discipline than the

\footnotetext{
${ }^{70}$ Jaramillo, et al., 1989: 48-49

${ }^{71}$ Jaramillo 2005

${ }^{72}$ Medina Arbeláez 2009
} 
ELN. ${ }^{73}$ Within the FARC maximum control is exercised by national leaders while within the ELN power is concentrated in the front commanders. Moreover, the ELN is more political than the FARC. The ELN separates political and military tasks and includes unarmed political militants. The FARC fuses military and political functions and practically all members have a place in the military hierarchy. Perhaps these slight organizational differences affected FARC and ELN authority at the local level. To deal with this, I present data showing that the FARC and ELN deploy similar economic strategies in regions with the same resource, which suggests the organizational differences do not have much relevance to this study.

Finally, some political scientists theorize that social networks matter because more cohesive networks result in stronger ties between insurgents and local populations. ${ }^{74}$ The cases of the FARC and the ELN in Caquetá and Arauca control for social networks because both insurgent groups had similar ties to the local peasant sector. The FARC was an overwhelmingly peasant organization. ${ }^{75}$ The ELN has a more urban membership overall, but in Arauca it recruited from among peasant settlers.

\footnotetext{
${ }^{73}$ Medina Gallego 2005

${ }^{74}$ Reed 2007; Staniland 2012

${ }^{75}$ Richani 2002
} 
Table 2.5, Comparing the FARC and the ELN

\begin{tabular}{|c|c|c|c|}
\hline Insurgent & Social Roots & Organization & Community \\
\hline $\begin{array}{l}\text { Revolutionary } \\
\text { Armed Forces } \\
\text { of Colombia; } \\
\text { FARC }\end{array}$ & $\begin{array}{l}\text { 1964, rural } \\
\text { insurgency; } \\
\text { popular base } \\
\text { includes } \\
\text { peasants and } \\
\text { urban } \\
\text { intellectuals; } \\
\text { some students }\end{array}$ & $\begin{array}{l}\text { centralized; } \\
\text { hierarchical; } \\
\text { disciplined; } \\
\text { political- } \\
\text { military } \\
\text { functions are } \\
\text { fused }\end{array}$ & $\begin{array}{l}\text { Frontier, } \\
\text { southern and } \\
\text { eastern plains, } \\
\text { Amazon } \\
\text { Departments: } \\
\text { Caquetá, } \\
\text { Meta, } \\
\text { Guaviare, } \\
\text { Putumayo, } \\
\text { Arauca, } \\
\text { Bolívar }\end{array}$ \\
\hline \multirow[t]{2}{*}{$\begin{array}{l}\text { National } \\
\text { Liberation } \\
\text { Army; ELN }\end{array}$} & $\begin{array}{l}\text { 1964, rural } \\
\text { insurgency; } \\
\text { popular base } \\
\text { includes } \\
\text { peasants, urban } \\
\text { intellectuals, }\end{array}$ & $\begin{array}{l}\text { federalized; } \\
\text { hierarchical; } \\
\text { disciplined; } \\
\text { political- } \\
\text { military } \\
\text { functions } \\
\text { separate }\end{array}$ & $\begin{array}{l}\text { Frontier; } \\
\text { eastern plains } \\
\text { and Caribbean } \\
\text { Departments: } \\
\text { Santander, }\end{array}$ \\
\hline & $\begin{array}{l}\text { religious } \\
\text { groups, urban } \\
\text { working class, } \\
\text { students }\end{array}$ & & $\begin{array}{l}\text { North } \\
\text { Santander, } \\
\text { Bolívar, } \\
\text { Arauca }\end{array}$ \\
\hline
\end{tabular}

\section{The Data}

I test my hypothesis with evidence collected during a total of six months of field research in Colombia in 2011 and 2012. Because of the nature of my study, it was not possible to follow a strict methodology during my field work. I was conducting research on two clandestine organizations that were still active and operating mainly in 
marginalized territories where outsiders had little access. Particularly for coca-growing regions like Caquetá, there was no systematic record of events, and the information available was sometimes incomplete or subject to bias. Government sources tend to downplay state violence and repression of coca growers, while some human rights organizations have underestimated the human rights abuses committed by insurgent groups. To address these difficulties in data collection, I relied on multiple types of information and data for each case. Despite these limitations, the project is still worthy of pursuit given its theoretical and policy value.

I conducted my field work in two steps. First, I began with documentary and archival work at two research centers; the Center for Research and Popular Education (CINEP) in Bogotá, and the Regional Studies Institute (INER) at the Universidad de Antioquia in the city of Medellín. The archives include regional historiographies and field notes recorded by scholars and journalists, a newspaper archive, testimonies from civilians and members of insurgent groups, and databases on conflict events and human rights abuses. I used this information to reconstruct the histories of the FARC and the ELN in Caquetá and Arauca and to document interactions with local populations in response to the coca and oil booms. For data on the location and density of illicit crop cultivation, I relied on the United Nations Office on Drugs and Crime coca and opium cultivation surveys for Colombia between 2003 and 2012. ${ }^{76}$

\footnotetext{
${ }^{76}$ The UNDC data is based on SIMCI satellite imaging. It is subject to limitations, since the visibility of illicit crops varies according to location (they can be hidden by large trees or other crops) and also by the time of year (whether the image is taken just before or after a harvest). However, it is the most reliable information available on illicit cultivation and the most widely used.
} 
Second, I supplemented my archival research with 58 semi-structured interviews with a wide range of actors including civil society leaders, members of human rights organizations, church leaders, government officials, demobilized insurgents, and civilians whose collective testimonies added to my understanding of local events. Fifteen of these interviews were with members of human rights organizations and university faculty at the Universidad Javeriana, the Universidad de los Andes, the Universidad de Antioquia, the Corporación Arco Iris, and the Permanent Committee for the Defense of Human Rights $(\mathrm{CPDH})$. Expert interviews provided a more nuanced picture of state and insurgent activities.

Thirty-four of the interviews were with demobilized FARC and ELN combatants. Semi-structured interviews with demobilized combatants were carried out at Service Centers for the Demobilized in Ciudad de Bolívar in Bogotá, and in Medellín, Colombia. ${ }^{77}$ I conducted interviews with the assistance of three agencies; the Care Program for Demobilization and Reintegration Process administered by the city of Bogotá, the Peace and Reconciliation Program administered by the city of Medellín, and the High Council for Social and Economic Reintegration of Individuals and Armed Groups (ACR) administered by the Colombian national government.

The remaining nine interviews were conducted in January 2012 during a field visit to the community of Arauquita, Arauca. There I spoke with two government functionaries, six human rights workers, and one member of the local JAC about the effects of oil on community relations with the insurgents. Arauquita was one of the few

\footnotetext{
${ }^{77}$ see Appendix A
} 
conflict zones accessible during a return visit to Colombia in 2012. Due to ongoing conflict and local elections that took place at the end of 2012, I was not able to visit other communities. ${ }^{78}$ Nonetheless, Arauquita offered a wealth of useful information. Both the FARC and ELN are present in Arauquita, a municipality that was at the center of a petroleum discovery in 1983 and also the site of illicit coca cultivation.

\section{Supplementary Cases and External Validity}

Finally, the strength of the method of difference design is that it allows for a strong test of the internal validity of my argument by controlling for plausible alternative hypotheses. However, the weakness of the design is that it does not test for external validity. The logic of my argument might account for the Colombian case, but does it work for other cases? To address this weakness, I rely on the secondary literature to construct brief case study analyses of non-Colombian insurgent groups interacting with licit and illicit resources. My case studies include the Shining Path insurgency in the coca-producing upper Huallaga Valley of Peru and insurgent exploitation of oil extraction in the Niger Delta region of Nigeria.

\section{Conclusions}

With this chapter, I laid out the core theoretical material of my research. My main objectives were to present a theory about war commodities and insurgent authority, compare that theory to rival hypothesis, and provide a description of the methodology I use to validate my arguments. The following chapters present the empirical evidence. I

\footnotetext{
${ }^{78}$ Tension and violence increase in conflict regions of Colombia during local elections. Hence, a local election period was not an opportune moment to do research in Caquetá.
} 
divided the evidence into two parts each with two separate chapters for the independent variable, commodity type, and the dependent variable, insurgent authority. Part one looks at the case of the ELN in the oil-producing region of Arauca and Part two looks at the case of the FARC in the coca-producing region of Caquetá. 
Part I:

Oil and Predatory Authority: The ELN in Arauca 


\section{Chapter Three \\ Oil: State Response to a Licit Commodity}

With the discovery of petroleum, the central government started to turn its eyes to this region, not to create progress but to take the riches from the region, and the presence of the petroleum multinationals, instead of bringing progress and development, brought violence. ${ }^{1}$

In a classic study of resources and conflict, Michael Ross argues that oil exacerbates conflict because it is lucrative and obstructable. ${ }^{2}$ Oil is capital intensive in all stages of production, but once production starts it generates huge profits with low labor costs. ${ }^{3}$ Hence, insurgents can claim a large rent without causing exit or draining profits. Oil companies, already highly invested, could theoretically transfer rents to insurgents as just another a costs of doing business. Indeed, there is great potential for mutual gain and cooperation between insurgents and oil companies. And yet, we find violence and contestation in practically all instances in which oil and conflict collide-in settings as diverse as Colombia, Nigeria, Iraq, and Angola. ${ }^{4}$ Oil tends to transform even the least violent insurgents into a predatory authority. ${ }^{5}$ In Colombia there are no oil-producing departments without violence, and the two most violent departments during the 1990s, Arauca and Casanare, were also the largest oil producers. ${ }^{6}$

What explains the relationship between oil and predatory authority? The core argument of this dissertation is that insurgent authority differs between licit and illicit

\footnotetext{
${ }^{1}$ Author interview with community leader and teacher on January 22, 2012 in Arauquita, Arauca, Colombia

${ }^{2}$ Ross 2002: 29; Dube and Vargas 2009: 19

${ }^{3}$ Dunning and Wirpsa 2004

${ }^{4}$ Kaldor, Karl, and Said 2007; Holmes and Gutiérrez de Piñeres 2012: 100; Fearon and Laitin 2003; Le Billion 2005

${ }^{5}$ Dunning and Wirpsa 2004: 86

${ }^{6}$ Holmes and Gutiérrez de Piñeres 2012: 100
} 
commodities because the state reacts to the former with protection, and to the latter with repression. This chapter looks at a licit commodity as one outcome of my independent variable. It focuses on the Colombian government's policies toward the oil industry in the department of Arauca. The chapter is divided into three parts. First, I describe the Colombian oil industry and the conflicts that surround it. Second, I show how a national interest formed on protecting oil, a war commodity that generated huge revenues for the state. Third, I link the national interest to the state's deployment of military protection and public goods to Arauca. I base my narrative on published sources, unpublished regional ethnographies and testimonies, and interviews with civilians and state officials that took place in Bogotá, Colombia in late 2011, and in Arauquita, Arauca in January of 2012.

\section{Antecedents: Oil and Conflict in Arauca}

Colombia is not a major actor in the international petroleum market, nor is it a petro-state. In fact, at the height of conflict in 2001 Colombia's reserves were just 0.2 per cent of world reserves. ${ }^{7}$ However, oil is Colombia's most important export and largest source of foreign exchange accounting for 35 per cent of export revenues in $2000 .^{8}$ Royalties and taxes from oil together provide the largest source of funding for military and security expenditures in Colombia. Moreover, Colombian oil production attracts considerable foreign aid because of its strategic value to the United States. Colombia is

\footnotetext{
${ }^{7}$ Pearce 2005: 28; As a percentage of GDP dependence on primary commodity exports in Colombia falls well below the 30 percent 'danger benchmark' for natural resources and conflict risk (see Richani 2005:114), yet Colombia has suffered more than half of century of internal strife

${ }^{8}$ Dunning and Wirpsa 2004: 86
} 
the fourth largest Latin American supplier of crude oil to the United States, and the U.S. contributes counter-terrorism support to protect the oil infrastructure in Colombia. ${ }^{9}$

Oil not only generates revenue, but also a great deal of violence for Colombia as a source of revenue for all actors to the conflict, both state and non-state. Yet, the literature on the Colombian conflict has very little to say about oil as a war commodity. ${ }^{10}$ In this section, I describe the relationship between the state, oil companies, and popular forces effected by oil production in Arauca, Colombia between 1983 and 2004. I show that in Arauca state protected the oil industry against insurgents and popular forces because of its economic reliance on oil royalties. Oil profits reached government coffers as royalties, taxes, and through foreign aid from the United States. By the late 1990s, about 85 per cent of profits from the oil industry were claimed by the state. Hence, the location of a major oil fields in Arauca, a department with high insurgent activity, meant that the state's most important commodity was vulnerable to insurgent attacks and rent-seeking.

\section{Oil in Colombia: Foreign Actors and National Interests}

The discovery of oil in Arauca in 1983 occurred amid national-level conflicts between foreign and national interests over the distribution of oil royalties. More than any other Latin American oil producer, the oil industry in Colombia constitutes a foreign-

\footnotetext{
${ }^{9}$ U.S. GAO Report-05-97; According to Dunning and Wirpsa, Colombia vacillates between the fifth and tenth top foreign oil supplier to the United States. Approximately half of the oil extracted in Colombia is exported to the United States (2004: 86).

${ }^{10}$ In Colombia the focus is on the drug trade and conflict. Only three studies specifically address oil and conflict: Nazih Richani's work on the war system and multinationals (2002, 2005), Jenny Pearce's work on oil and conflict in Casanare (2005, 2007), and Dunning and Wirpsa's article on international linkages, oil, and conflict in Colombia (2004)
} 
controlled enclave. ${ }^{11}$ Hence, the conflicts generated by the oil industry are nationalist conflicts that evoke the state as the arbiter between foreign multinationals and popular forces most cogently represented by the Oil Trade Workers Union (Unión Sindicalista Obrera; USO). In this section I describe how the Colombian state has sided with the multinationals in these conflicts. Foreign companies provide most of the capital for exploration and infrastructure which generate royalties for the state. Indeed, association contracts between multinationals and the government claim 60 percent of oil royalties for Colombia. The state's deployment of resources and manipulation of association contracts to protect foreign multinationals has exacerbated local conflicts with popular forces, including peasants and workers that form part of the social base of insurgent groups.

Foreign control of Colombian oil has been in place since the country started exporting oil in the 1920s, and foreign oil companies have always clashed with popular forces. During the 1920s, Tropical Oil Company, a U.S.-based multinational, controlled Colombia's petroleum enclave in the Magdalena Medio region. During the 1930s, Texas Petroleum would become the dominant multinational in the Magdalena Medio oil enclave town of Puerto Boyacá. ${ }^{12}$ Tropical Oil and Texas Petroleum established purely extractive operations in Colombia resulting in conflicts with workers and communities. In the first place, the oil companies' exploration and extraction activities uprooted peasants from their lands, something the national government contributed to by ceding peasant lands to

\footnotetext{
${ }^{11}$ At the end of the 1970s nearly every major oil-producing country had at least partially nationalized oil production. The nationalization trend has progressively reversed in most countries alongside a reintensification of foreign direct investment; Dunning and Wirpsa 2004:81-82

${ }^{12}$ Medina 1990
} 
oil multinationals. ${ }^{13}$ Second, the oil companies maintained horrendous working conditions and wages, and invested little in local development. ${ }^{14}$ In time, oil workers organized and formed the Oil Trade Workers' Union (USO). The USO is the largest and most powerful workers' union in Colombia with headquarters in the city of Barrancabermeja, which is at the center of the vanguard territory of the ELN insurgency. Not surprisingly, early on organized oil workers made up a critical part of the ELN's urban social base.

In addition to improving wages and working conditions, the USO successfully pressured for the nationalization of the petroleum industry in 1951 with the founding of the state-owned oil company Empresa Colombiana de Petróleos (Ecopetrol). ${ }^{15}$ That year, Tropical Oil's thirty year concession in Colombia expired. To appease the USO, the Colombian government chose not to renew the concession, and control over the oil fields reverted to Ecopetrol, the largest state-owned company in Colombia, and the only one that owns a majority of any part of a natural resource industry. ${ }^{16}$ Nationalization of oil in Colombia lasted a mere two decades. Beginning in the 1970s, Ecopetrol's control over the oil industry was chipped away by a process of privatization through association contracts between Ecopetrol and two foreign multinationals: the U.S. Occidental Petroleum and British Petroleum (BP).

The association contracts, which began in 1969, are contracts through which Ecopetrol and the foreign companies share information and the costs associated with oil

\footnotetext{
${ }^{13}$ Richani 2005: 119

${ }^{14}$ Medina 1990

${ }^{15}$ Pearce 2005: 17

${ }^{16}$ Dudley and Murillo 1998
} 
exploration. The contracts split the profits between Ecopetrol and the foreign company while shifting the financial burden of exploration and infrastructural costs mostly on the foreign company. In this way, the association contracts seem favorable to the state. However, because foreign companies garner greater technological and financial resources than Ecopetrol, they have been able to crowd out Colombia's national oil company such that the company had 216 active wells in 1986 and only two in $1998 .^{17}$ In addition, Ecopetrol's exploration activities have significantly declined. Dudley and Murillo explain:

"...the association contracts with foreign companies have undermined Ecopetrol's ability to develop independently. With each successive renegotiation, the company's revenue base and its negotiating position vis-àvis the multinationals have deteriorated...By the 1960s [prior to the association contracts] Ecopetrol was drilling in previously unexplored areas and finding several large reserves that other companies had overlooked. It was so successful that the multinationals began to point Ecopetrol to areas that they knew were dry so that Ecopetrol would give up exploring...forcing Ecopetrol to phase out all exploration. In 1988, the company explored 3,245 square miles of territory, but by [the mid-1990s] that figure was down to 621, and in 1997 there was no exploration at 0. This has left Ecopetrol at the whim of the multinationals, which often use Ecopetrol's information and then apply their capital to get at the most profitable wells, "18

Large-scale privatization of the oil sector picked up during the 1990s, subsequent to discoveries in Arauca and Casanare. President Cesar Gaviria (1990-1994) passed a number of labor and tariff reforms to attract international investors. However, the first effort to fully privatize Ecopetrol took place under President Ernesto Samper (1994-

\footnotetext{
${ }^{17}$ Dudley and Murillo 1998; association contracts also resulted in a crowding out of Colombian investors. Today, there are few private Colombian investors in the petroleum industry, and the few that do exist are limited to marginal enterprises like fuel redistribution and pipeline construction.

${ }^{18}$ Dudley and Murillo 1998
} 
1998). Samper's privatization scheme failed, mainly due to the activities of the USO. Nonetheless, the Colombian government managed to expand the association contracts to attract foreign investment. Beginning in 1994, the state introduced several laws like FACTOR R, which divided production income between Ecopetrol and the foreign multinational taking into account the multinational's accumulated investment costs in exploration and operations. The share of profits claimed by the national company ECOPETROL was reduced from its previous full 50 per cent, to 50 per cent after the production of 60,000 barrels and after discounting 20 per cent for royalties to the government. ${ }^{19}$

In 2002, the association contracts were once again changed to reflect an even greater return for foreign multinationals. Rather than a twenty per cent flat rate for multinationals, a flexible rate was put in place that depended on production volume and changes in international prices. The new more flexible rates resulted in a new distribution such that the associated foreign entity received on average 30 per cent. The legislation was controversial and strongly opposed by the USO. Organized labor argued that Ecopetrol already claimed a much lower share of profits compared to other national oil companies in Latin America. ${ }^{20}$

Indeed, by 2003 Ecopetrol had become merely a 'contract manager' with scarce participation in the oil economy and without the right to undertake operations. The national company hardly produced but 18 per cent of Colombian petroleum, and even

\footnotetext{
${ }^{19}$ Pearce 2005: 24

${ }^{20}$ ibid: 22-23; Richani 2005: 116
} 
then foreign interests dictated the rate of petroleum extraction and exporting. ${ }^{21}$ Other oil producing states, such as Japan and the United States, regularly decrease the rate of petroleum extraction as a strategy for conserving energy so that the country is importing oil when prices are low, and extracting from the national reserve when prices are high. In Colombia, extraction was accelerating when prices were high so that the multinationals could take advantage of higher profits. ${ }^{22}$

The USO has been the main actor in opposing the association contracts that have shifted control of Colombia's oil industry to foreign companies. Indeed, the USO successfully blocked President Samper's privatization scheme by threatening a "slow shut-down of operations until a 'zero hour' when there would be a national strike," ${ }^{23}$ For their involvement in oil politics and historic links to the $\mathrm{ELN}^{24}$, USO leaders became targets of systematic violence by state and right-wing paramilitary forces that were at times working on behalf of the oil multinationals. ${ }^{25}$ Right-wing paramilitary groups, in some cases with lists of union leaders provided by the Colombian Administrative Department of Security (DAS), selectively disappear and assassinate USO members. ${ }^{26}$ Between 1987 and 1998, 80 USO leaders were assassinated by paramilitary forces

${ }^{21}$ Pearce 2005: 21-23

22 "Una Propuesta Energética del ELN" (1999), in El Mandato Ciudadano por la Paz, la Vida y la Libertad; Petróleo en las Conversaciones de Paz, Bogotá: 188

${ }^{23}$ Dudley and Murillo 1998

${ }^{24}$ Colombian President Samper publically denounced the USO as a 'terrorist cartel' and accused USO leaders of belonging to the ELN without evidence of a formal link. See Dudley and Murillo 1998

${ }^{25}$ In 1992, British Petroleum signed a protection contract with Defense Systems Limited (DSL), a private company that provides counterinsurgency services in 26 countries. DSL reportedly trained Colombian police in counterinsurgency techniques to protect the oil field in Casanare; Dudley and Murillo 1998

${ }^{26}$ Former Colombian DAS director Jorge Noguera Coce was accused of supplying paramilitaries with names of delinquents and trade unionists who were subsequently disappeared or assassinated; El Tiempo, section: justicia, March 10, 2007 
working in conjunction with the government. In December of 1996, twenty USO members were detained by military forces and charged with the crime of rebellion. ${ }^{27}$

For their part, oil companies organized their interest through the Colombian Petroleum Association (ACP) which was formed in 1965, but which has never obtained the authority of other organized sectors including the coffee producers' federation. ACP remained a relatively weak pressure group because the association is internally divided by national and foreign companies. While the industry is dominated by just two foreign 'mega-firms' BP and Occidental, Colombian efforts to attract foreign investment brought 70 foreign companies to Colombia by $2002 .{ }^{28}$ Despite internal conflicts, the ACP unites all oil companies in favor or government protection of the oil industry from insurgent predation. The state has responded favorably. Even while military efforts have not eliminated the threat, the state has dedicated the more resources to protect the oil industry than any other economic sector in Colombia.

\section{The Oil Windfall in Arauca}

Arauca is a frontier department to the east of the capital city of Bogotá that shares a frontier with Venezuela and makes up the extreme north of the eastern plains region of Colombia known as the llanos orientales (eastern plains). In Arauca, there is a strong llanero identity which places the region culturally and socially more with neighboring Venezuela than Colombia. ${ }^{29}$ When oil was discovered in Arauca in 1983, the then Commissary of Arauca had a population of less than 100,000 in a territory that spanned

${ }^{27}$ Dudley and Murillo 1998

${ }^{28}$ Pearce 2007: 247

${ }^{29}$ Author interview with Kyle Johnson, Research association with Corporación Nuevo Arco Iris, September 28, 2011, Bogotá, Colombia 
23,818 square kilometers. ${ }^{30}$ About sixty per cent of the population was made up of landless peasants, including subsistence farmers and newly arrived colonos.

Indeed, Arauca was part of the sparsely populated 'national territory'. The national territory included those peripheral regions of Colombia that were economically and politically marginalized. Prior to the discovery of oil, Arauca was hardly an interest for the central government in Bogotá. The territory had only been advanced from an Intendancy to the status of Commissary in 1955. Prior to that, Arauca was annexed to the departments of Cundinamarca and later Boyacá. Arauca was not recognized as a department of Colombia until 1991 when, under a new Constitution, all of Colombia's intendancies and commissaries became departments. ${ }^{31}$ Table 4.1 presents data on the presence of the State in Arauca in 1993 and 2005.

Table 3.1: State Presence and Development Indicators, Arauca ${ }^{32}$

\begin{tabular}{|c|c|}
\hline Indicator & 5.9 \\
\hline Average years of schooling, 1993 & 78 \\
\hline Percent homes with water, 2005 & 70 \\
\hline Percent homes with sewage, 2005 & 53.7 \\
\hline Percent living in Poverty, 1993 & \\
\hline
\end{tabular}

${ }^{30}$ Pearce 2005: 40

${ }^{31}$ Prior to 1991, there were four types of political divisions in Colombia: departments, commissaries, intendancies, and special districts. Most of the national territory was Intendancies and Commissaries, a label which distinguished these areas from the integrated core regions of the country; El Tiempo, July 7 , 1991, A partir de hoy, no más intendencias ni comisarías, eltimpo.com/archive/document/MAM-166769

${ }^{32}$ Holmes and Gutiérrez de Piñeres 2012: 101 
Although there is no data on state capacity available for the Intendancy of Arauca before 1993, local testimonies tell of the 'complete abandonment' of the state prior to 1983. The descriptions are consistent with the standard portrayal of Arauca as a 'disarticulated and politically marginal territory' with minimal state presence or interest. $^{33}$ As one local explains:

“...thirty years, thirty two years ago I came here [to Arauca]. The department of Arauca was what was called a commissary, it wasn't an intendancy but it also wasn't a department. In other words, the presence of the state was extremely weak. We say that it was a complete abandon, complete abandon in all aspects. In terms of the obligations of a State as such, in its presence. And the people that lived here, well, the people survived without the State, without government, without anything, and without having their basic needs met. There was no health care, no education, it didn't exist. So, I'd say that the root of things was state abandonment during the 1970s in these territories that they called 'national territory', ", 34

“...In order to make a telephone call it took three days, to make a call to Bogotá. One day traveling there [to the municipal center], another day there waiting five or six hours in order to make the call, and one day returning. So, it was three days to call your mother which cost $\$ 200$ pesos per minute, "35

During the 1950s and 1960s Arauca was affected by the same process of frontier colonization as the Western Amazon where the coca economy developed. The piedmont of Arauca was a vast plain of unclaimed public land and this is attracted the settlers. ${ }^{36}$ The Colombian government attempted to control the colonization process through

\footnotetext{
${ }^{33}$ For a history of Colombia's llanos frontier see Rausch, Jane M. (1999) Colombia: Territorial Rule and the Llanos Frontier, University Press of Florida

${ }^{34}$ Author interview with former government official, January 20, 2012, Arauquita, Arauca, Colombia

35 ibid

${ }^{36}$ ibid
} 
INCORA. ${ }^{37}$ Between 1970 and 1976, The Colombian Institute of Agrarian Reform (INCORA) provided assistance to about 8,000 families or 60,000 persons to settle public lands in the sparsely populated piedmont region of Arauca that bordered Venezuela called el Sarare. The Sarare region, including the municipalities of Fortul, Arauquita, Tame, and Saravena, became the hub of the U.S. private company Occidental Petroleum (Oxy) when oil was discovered there in $1983 .^{38}$

While Colombia has been an oil exporter since the 1920s, oil production was only a small part of Colombia's GNP prior to the discovery of oil in Arauca and a subsequent find in a neighboring department, Casanare. The boom in oil production in the 1980s and 1990s made Colombia a net petroleum exporter. ${ }^{39}$ Occidental Petroleum discovery of an oil field in Sarare was a windfall for the department. The field was at the mouth of the Caño Limón River about seven miles south of the Venezuelan border. At the time, it was estimated that Caño Limón had potential reserves of more than 1,000 million barrels. ${ }^{40}$ The discovery was followed by a three year construction project to build the Caño Limón-Coveñas pipeline, a 477 mile underground tube that transports pumped oil through seven Colombian departments from Arauca to the Caribbean port of Coveñas. ${ }^{41}$

\footnotetext{
${ }^{37}$ INCORA was tasked with resolving local conflicts and integrated the newly arrived peasant population by distributing land titles and credits. Nonetheless, while the central government provided the resources to INCORA, ultimately it was local power brokers, that controlled the distribution of resources. The ELN and the FARC controlled INCORA with 'pamphlets, phone calls, and death threats'; Peñate 1998: 21

${ }^{38}$ Richani 2005: 121

${ }^{39}$ Pearce 2005: 22; Colombia was a net petroleum exporter in the 1920s, but lost that status in the 1950s.

${ }^{40}$ The field runs north-south about 8,000 feet beneath the Arauca River

${ }^{41}$ From the field at Caño Limón the pipeline travels northwest 770 kilometers through the departments of Boyacá, Norte de Santander, Cesar, Magdalena and Bolívar to the Caribbean port of Coveñas in the department of Sucre.
} 
Ownership of the pipeline was split fifty-fifty between Occidental Petroleum and Colombia's national oil company, Ecopetrol, while the Caño Limón oilfield itself was operated by the Cravo Norte Association (CNA), which is a joint venture between Ecopetrol and Occidental. ${ }^{42}$ In this way, the national government shared the cost and profits of oil exploration. In addition, a small amount of production at Caño Limón was owned by a Spanish oil company, Repsol through a sub-contract with Occidental. ${ }^{43}$ In 1986, Caño Limón began to produce at a rate of 250,000 barrels a day. By 2005 the Araucan oil field was producing 20 per cent of Colombia's oil exports. ${ }^{44}$

While Arauca is the main focus of this chapter, it is worth mentioning that a second major oil discovery took place in 1991 in Casanare, a conflict region similar to Arauca. Casanare's Cusiana and Cupiagua oil field were discovered by British Petroleum (BP). As in Arauca, the discovery of oil in Casanare was a resource windfall for the marginalized, frontier community. ${ }^{45}$ BP's discovery was the largest finding of crude oil in the history of Latin America. ${ }^{46}$ It brought significant foreign investment and generated enormous revenue for the national and local government. Like Caño Limón, Cusiana and Cupiagua are operated by a foreign multinational, in this case British Petroleum, while the national company Ecopetrol owns 50 per cent of the infrastructure

${ }^{42}$ U.S. Dept. of State 2002; U.S. GAO Report GAO-05-971

${ }^{43}$ CNA owns the production facilities, the pipeline and Coveñas port terminal. Occidental manages the oilfield production and Ecopetrol operates the pipeline. The breakdown of membership within CNA is roughly fifty percent Ecopetrol, 44 percent Occidental, and 6 per cent Repsol; U.S. GOA Report GAO-05971; U.S. Dept. of State 2002

44 Peñate 1998:23; U.S. GAO Report GAO-05-971; U.S. Dept. of State 2002

${ }^{45}$ Pearce 2005: 29, 228

${ }^{46}$ Cuisana was first discovered by Ecopetrol in the early 1970s. At that time Ecopetrol lacked the resources for accessing the main deposits. In 1991, BP invested US\$140 million in order to exploit the wells; Dudley and Murillo 1998; Pearce 2005 
and production. ${ }^{47}$ Moreover, Casanare is also a conflict region occupied by multiple armed groups that fund themselves with oil rents including the ELN, the FARC, and right-wing paramilitaries.

\section{Oil and Conflict in Arauca}

The discovery of oil in Arauca generated conflicts. In the first place, oil jobs attracted a population explosion in region with scant resources and public services. In the second place, oil brought oil multinationals to Arauca whose interests and activities infringed on the peasant communities that had long since colonized the zone surrounding the oil field. At the same time, the department benefited from the economic windfall, and the state therefore protected the oil industry vis-à-vis popular pressures. Caño Limón brought a flood of capital to Arauca, producing \$195 million over five years for the regional government and royalties for the municipalities.

First, the rapid population increase threatened the well-organized and mostly selfgoverning peasant communities in the Sarare region. The population of Arauca increased from 100,000 to about 250,000 by $1993 .{ }^{48}$ New towns, roads and a service sector sprung up practically overnight. ${ }^{49}$ Richani describes a similar dynamic in neighboring Casanare: “...the rapid construction projects and a sudden huge cash flow of $\$ 100$ million in oil royalties into a peasant 'noncash economy' have radically transformed the socioeconomic structures in many of the departments' communities, ${ }^{50}$ The population of Casanare's oil-

\footnotetext{
${ }^{47}$ Pearce 2005: 29

${ }^{48}$ U.S. Dept. of State 2002

${ }^{49}$ Pearce 2007: 22

${ }^{50}$ Richani 2005: 119; also see McPhail 2000
} 
producing municipalities increased 150 per cent between 1993 and 1996, and neighboring municipalities saw population increases of 10 percent a year. ${ }^{51}$

Indeed, oil generated an explosion of people and economic activity in Arauca comparable to the illicit coca boom in the Western Amazon. The oil industry was less labor intensive than coca, but nonetheless offered high wages that attracted workers. The average oil worker earned three times the salary of a farm worker. ${ }^{52}$ Migrants arrived by the thousands. The oversupply of labor resulted in a large transient population of parttime and seasonal workers called malleros. ${ }^{53}$ The mallero can be likened to the raspachines who are temporary, contract workers that harvest coca in the Western Amazon. In both cases, lucrative employment opportunities in oil and coca brought an unstable populations without roots in the community and with interests different from the settled population.

Therefore, in addition to the inflationary pressures on the local economy and a significant increase in the cost of living, oil brought a population with "...heterogeneous social backgrounds... the type of political culture of those who are attracted to this type of life clashed with the traditional peasant values that previously had strengthened the region's social fabric," 54 In Arauca, conflicts between locals and migrants were exacerbated by the companies' preference for non-local hiring. Migrants arrived in

\footnotetext{
${ }^{51}$ Richani 2005: 120

${ }^{52}$ Reports that the average peasant laborer makes about US $\$ 4.00 /$ day, while the average oil worker makes about US\$6.50/day in addition to a subsidy for food and transportation which increases the oil worker's income to around US\$13.00/day; Richani 2005: 119

${ }^{53}$ In the main oil producing municipalities of Casanare about thirty to forty per cent of men over the age of 15 were out of work for 9 months of the year, and yet they maintained an annual salary higher than that of a minimum wage worker; Richani 2005: 119

${ }^{54}$ Richani 2005: 119
} 
droves hoping for gainful employment in the oil sector. Of Arauca's 250,000 people about 20,000 reside in the municipal capital where, according to local testimony, they had more access to jobs in the oil sector. A community leader in Arauquita, Arauca, explains:

...The petroleum multinationals and the contractors of those multinationals did not hire labor from Arauquita because of the threat of the guerillas. So, a local that wanted to work with a petroleum company had to move and live in Arauca [the departmental capital] and then do what was called a process that is an investigation of their origin to see who the person is and where they come from, and if they should be allowed or denied access to two weeks of work on average... 55

Some of the social and economic tensions caused by the oil boom were expressed through violence as indicated by rising homicide rates. In Casanare, the homicide rate rose from 48 per 100,000 in 1988 to 112 per 100,000 in 2001, which was far above the national rate of 63.7 homicides per 100,000. Between 1989 and 1994 Casanare experienced 1,115 documented political homicides, the highest of any department in Colombia during this time period. The vast majority of victims were peasants and especially colonos (recently settled peasants from other regions) that were targeted for forced evictions or assassinations due to the increasing value of land. By 2002, both Arauca and Casanare had been transformed from relatively peaceful and uninhabited frontiers to the two most violent departments in Colombia. ${ }^{56}$

Second, in Arauca oil extraction generated conflicts between the peasant sector and foreign and national oil companies. The peasant colonos who occupied the territories surrounding the oil installation were threatened by the construction of an oil infrastructure that encroached on their lands and generated profits for foreign

\footnotetext{
55 Author interview with a community leader and teacher in Arauquita, Arauca, January 22, 2012
}

56 Bejarano 1997: 116; Richani 2005: 120; Vicepresidencia 2002: 301 
multinationals at the expense of the community. Through protest and strikes, the peasants sought to secure a larger share of the royalties for community programs and local development. ${ }^{57}$ Despite a lack of resources, the peasant sector in Sarare held political sway in Arauca because their arrival had disrupted the traditional power balance between Liberal and Conservative forces. ${ }^{58}$ Meanwhile, the central government protected the oil industry against popular demands, since the activities of the foreign multinationals resulted in huge royalties and taxes that accrued directly to the Colombian state.

Even prior to the discovery of oil, the peasant sector in Sarare was a political force. Early on, the peasants formed civic boards and councils as vehicles for articulating their interests. When the German contractor Mannesmann Ltd. began construction on the Caño-Limón pipeline in 1983 the company came in direct conflict with the peasant settlers who claimed that the construction infringed on their properties. A small segment of the population reacted to the pressures on land by expanding the frontier, opening up new public lands. In some cases, this expansion led to new cultivations of illicit coca. Arauca was not a major source of illicit coca. However, by 2005 about 12,000 hectares of coca were cultivated in the area concentrated not coincidentally in the Sarare municipalities of Fortul, Arauquita, and Saravena. ${ }^{59}$

Nevertheless, most Sarare peasant settlers did not turn to illegal cultivation. Despite the high profits associated with coca, the risks were high. Hence, most of the

\footnotetext{
${ }^{57}$ Pearce 2005: 42

${ }^{58}$ The peasant colonizers in Sarare broke the near equal distribution of Liberal and Conservative support that characterized Arauca prior to the colonization. Since the peasant communities determined electoral outcomes, they capitalized on this scenario by bargaining with party patrons. Pearce 2005: 242

${ }^{59}$ Richani 2005: 121
} 
colonos in Sarare responded by pressuring for a greater share of the benefits of oil. They organized a series of civic strikes and popular protests, demanding a 'piece of the pie' so that oil royalties would be invested in local employment, infrastructural development, and community programs. Since they occupied the zone where the oil was extracted, the colonos argued that they should be included in a fair distribution of income in the interest of 'the common good'. ${ }^{60}$ The departmental government agreed to greater public investment of oil royalties, but this hardly appeased the protesting peasants. In addition to public spending, the peasants also sought local control over the contracts arranged to execute the public projects so that they could capture the contract jobs. ${ }^{61}$

In this way, the peasant colonizers of Sarare challenged the oil companies, the national government, and the local political elite and their control over the allocation of resources. With the support of the National Liberation Army after 1983, they were largely successful. Andrés Peñate calculates that by 1990, the Sarare region benefited from half of the oil royalties that remained with municipal and regional governments even though only one third of the population of Arauca lived there. ${ }^{62}$ Their success was linked to the ELN's 'Robin Hood' strategy which included a 'community tax' paid by oil companies to fund local projects, provide jobs to ELN supporters, and subcontract with companies that paid the ELN a percentage of the profit. At least initially, the peasant sector benefited from the ELN's activities.

\footnotetext{
${ }^{60}$ Pearce 2005: 45

${ }^{61}$ ibid

62 ibid
} 
In sum, the discovery of oil in the frontier department of Arauca was a windfall for the sparsely populated and marginalized region. However, the confluence of a population explosion and the arrival of foreign multinationals generated conflicts with local peasant communities. The Colombian government responded to these conflicts mostly by siding with the oil multinationals. In so doing, the state was acting on behalf of the national interest, since the activities of multinationals generated huge profits for the Colombian government. I show in the next section that, in the context of an ongoing internal conflict, oil royalties were indispensable for building and maintaining the state's security forces and for that reason the state deployed the military and earmarked public monies for social development projects to protect the oil sector.

\section{II. . Oil and the National Interest}

"...the income obtained from protection, taxes, and profits from the extractive sector was vital [for the Colombian state] to finance its war with the insurgency, and the insurgents menace made the state even more... dependent on the extractive sector, ",63

The critical difference between licit and illicit war commodities from the state's perspective is that the former provides the government with revenue while the latter does not. The presence of licit war commodities shapes the dynamic of conflict at the local level into one in which the state depends on the very same resources that insurgents target for rents. Oil exports make up a mere one third of Colombia's export revenue, yet in 1999 oil exports provided the central government with US\$3.2 billion, which was a quarter of the government's total revenue. Between July of 2001 and June of 2002 the Caño Limón

\footnotetext{
${ }^{63}$ Richani 2005: 128
} 
oil field specifically produced US\$ 500 million in revenues for the Colombian government despite the complete shutdown of the pipeline due to guerrilla attacks for seven of the 12 months. ${ }^{64}$ After the combined income from royalties, government taxes, Ecopetrol's remittances and taxes ${ }^{65}$, and transfers to the National Royalty Fund along with state and municipal funds, the Colombian government retained about 85 per cent of gross revenue from production at Caño Limón. ${ }^{66}$ Oil was therefore vital to the national interest defined as the state's interest in monopolizing and consolidating power within its territory.

Indeed, government dependence on oil revenue in Colombia is very high, especially since Colombia is not a petro-state. ${ }^{67}$ For this reason, repression is problematic as a strategy for undermining insurgents' access to oil rents, since the state is equally dependent on oil production and has a strong interest in encouraging greater production. There are three modes by which the state accesses oil rents: direct accrual of oil royalties, taxes, and foreign counterinsurgency and counter-terrorism aid from the United States with the explicit purpose of protecting Colombian oil, vital to the U.S. security agenda.

First, oil provides revenue to the state by way of direct transfer of royalties to national and local governments, and to the state's national oil company Ecopetrol. Petroleum is by far Colombia's most important export, even surpassing coffee exports in

\footnotetext{
${ }^{64}$ During that same time period, the Cravo Norte Association earned approximately US $\$ 331$ million, much less than the projected US\$840 million that would have been earned if the pipeline had been operational for the entire year.

${ }^{65}$ Ecopetrol earned a gross income of about US\$169 million in 2001 just production at Caño Limón. The revenue supports Ecopetrol's operating costs and materials, investment, in addition to remittances to its owner, the Colombian Government; U.S. Dept. of State 2002

${ }^{66}$ U.S. Dept. of State 2002

${ }^{67}$ Richani 2005: 127
} 
the 1990s. In 1999, petroleum exports were 32 per cent of total exports and 3 per cent of Colombia's gross domestic product. ${ }^{6}$ Income from oil has been particularly important for public finance in Colombia, producing for the state a net income of $\$ 2,000$ million dollars in 1990 which was about 25 per cent of total government income. ${ }^{69}$ Rents generated from oil exports accrue to the Colombian government by virtue of the state's sovereign jurisdiction over natural resources. ${ }^{70}$ While foreign multinationals control the exploration and extraction of oil in Colombia, the resource itself belongs to the state.

Indeed, the association contracts that give power to foreign multinationals ultimately favor the state in economic terms. The contracts essentially transfer most of the cost for exploration and infrastructure to the multinational oil companies while claiming 60 per cent of royalties for Colombia. Hence, between 1986 and 2002, the Caño Limón oilfield generated $\$ 800$ million in royalties for the national government and about $\$ 1.2$ billion in royalties for the regional governments in the seven Colombian departments it transverses. ${ }^{71}$ Meanwhile, oil multinationals risk large sums of money searching for new deposits that in about 80 per cent of cases are not found. Further, upon discovering a large field foreign multinationals have to negotiate with ECOPETROL such that ECOPETROL receives 15 cents on every dollar earned. ${ }^{72}$

\footnotetext{
${ }^{68}$ Dudley and Murillo 1998; Pearce 2005: 29

${ }^{69}$ Pearce 2005: 30

${ }^{70}$ Kaldor, Karl, and Said 2007: 12

${ }^{71}$ U.S. GAO Report GAO-05-917; The Caño Limón-Coveñas pipeline transverses the departments of Arauca, Boyacá, Norte de Santander, Cesar, Magdalena, Bolivar, Sucre

${ }^{72}$ El Tiempo, April 21, 1997, La guerilla nos acorrala: OXY, retrived from the CINEP newspaper archive, Bogotá, Colombia
} 
Under the contract agreements oil royalties are distributed 20 per cent to the national government along with the armed forces and municipalities, 40 per cent to the state-owned oil company ECOPETROL, and 40 per cent to the foreign company. ${ }^{73}$ However, in 1997 Stephen Newton, the President of Occidental in Colombia, reported that about 85 percent of the rents generated by their business in Colombia goes to the government of Colombia. "We [Occidental] pay 50 per cent of the costs to gain hardly 15 per cent of the profits" ${ }^{\text {74 }}$ Further, Newton said that idea espoused by insurgents and popular forces that foreign multinationals are 'stealing the oil' in Colombia is entirely unfounded. "The guerilla knows perfectly well that attacking the pipeline is costing the government a lot of money,",75

Since the early 1990s, a considerable share of oil royalties have been distributed from the so-called National Royalties Fund to the municipalities where oil is produced in an amount proportionate to local production. ${ }^{76}$ Fiscal decentralization is generally seen as part of a broader process of democratization and political integration that took place in Colombia between 1986 and 1991. In oil producing regions, the main intent of fiscal decentralization was to politically integrate the region by linking the interests of local elites and communities to the national interest in encouraging growth of the oil industry. What is more, decentralization left oil royalties in local coffers that were earmarked by national legislation for development spending. In 1991 Colombia established a new

\footnotetext{
${ }^{73}$ Dudley and Murillo 1998

${ }^{74}$ El Tiempo, 4/21/1997, La guerrilla nos acorrala: OXY; article retrieved from CINEP newspaper archives in Bogotá, Colombia

75 ibid

${ }^{76}$ Holmes and Gutiérrez de Piñeres 2012: 100
} 
Constitution that institutionalized the allocation of oil and other mineral royalties in favor of local governments.

Specifically, the 1991 Constitution allocated 9.5 per cent and 2.5 per cent of royalties respectively to the province and municipalities with active oil wells. ${ }^{77}$ However, a tiered system was later established that varied the percentage for municipalities in line with production. ${ }^{78}$ The result of the tiered distribution is 32.10 per cent of royalties for the central government and 42.7 percent for the departments and municipalities. ${ }^{79}$ As a result of fiscal decentralization, during the 1990s Arauca was among the wealthiest departments in Colombia with oil revenues contributing 70 per cent of the total budget. ${ }^{80}$ In addition to oil royalties, the Colombian government also taxes foreign multinationals operating in Colombia. Beginning in 1992, the Colombian government began collecting a 'war tax' from oil companies. The amount of the tax was US $\$ 1.50$ per barrel of oil to cover the additional costs of maintaining a military presence in oil producing regions. Occidental Petroleum reports paying a war tax of US\$17 million in 1997 alone. ${ }^{81}$ According to Occidental, in 1997 ten per cent of their operating budget in Colombia went to security expenditures-most to the Colombian army. In all, foreign

${ }^{77}$ Pearce 2007: 227

${ }^{78}$ A field producing up to 5,000 barrels per day (bpd)-about 85 per cent of fields in Colombia- claims 5-8 per cent of royalties for the municipality. Production between 5,000 and 125,000 bpd results in a higher percentage for the municipality that increases until it reaches 20 per cent. Finally, production of 125,000 to $400,000 \mathrm{bpd}$ results in a flat percentage rate for the municipalities of 20 per cent; Dunning and Wirpsa 2004: 106, footnote 25

${ }^{79}$ Additional royalties went to the National Royalties Fund at 22.04 percent, and 2.55 per cent to the Social Support Fund. Pearce 2005: 41, footnote

${ }^{80}$ Guáqueta 2003:84-85; fiscal decentralization empowered insurgents because under the 1991 Constitution the officials that controlled oil revenues were elected by local constituencies. Insurgents would provide votes to get candidate into office in order to access to oil royalties. Hence, decentralization served to further exposed oil rents to insurgent exploitation in the context of newly formed and fragile local administrations

${ }^{81}$ El Tiempo, 4/21/1997, La guerrilla nos acorrala: OXY; article retrieved from CINEP newspaper archives in Bogotá, Colombia; Richani 2005: 116 
multinationals working in extractive industries in Colombia paid US\$100 million in war taxes to the central government in 1997. Of course, the amount was far less than the US\$250 million paid by the state-owned company Ecopetrol, of which US\$2.5 million went to protect a single battalion in Casanare. The total of $\$ 350$ million in war taxes paid to the Colombian government in 1997 constituted about 8.14 per cent of government expenditures on defense. ${ }^{82}$

Importantly, oil multinationals succeeded in phasing out the 'war tax' beginning in 2001 based on the increasing security costs that the companies were directly taking on through contracts with local military units. ${ }^{83}$ However, the Colombian government in part substituted the war tax with other forms of taxation including income, transportation, and remittance taxes paid to the national government and a transport tax which was collected by municipal governments. The amount paid in local transport taxes is proportionate to the length of oil pipelines that transverses the municipality. ${ }^{84}$

Income from petroleum, more than any other export commodity, supports the Colombian government's efforts to expand and professionalize the military to consolidate control over territory and combat insurgent and criminal organizations. Military professionalization began under Colombian President Andres Pastrana (1998-2002) and was accelerated under the administration of Alvaro Uribe (2002-2010) as part of Uribe's militarized counterinsurgency plan, Plan Patriota (Patriot Plan). Plan Patriota was

\footnotetext{
82 Dunning and Wirpsa 2004: 91; Richani 2005: 128

${ }^{83}$ Pearce 2005: 32; Richani 2005: 116

${ }^{84}$ Holmes and Gutiérrez de Piñeres 2012: 100; U.S. Dept. of State 2002
} 
implemented in 2004 and largely targeted FARC-controlled territories in the southern plains and Amazon regions with military incursions.

Finally, Colombia's national interest vis-à-vis the oil sector cannot be understood outside of the international politics of oil, and in particular the economic and security interests of the United States. Colombia is the United States' most secure ally in South America. Colombia has long received U.S. aid to combat illicit drugs as part of the United States' 'War on Drugs'. However, after 2001 Colombia began receiving military and counterterrorism aid from the U.S. earmarked for protection of the oil industry. Colombian oil matters to the United States because it is central to U.S. efforts to diversify oil imports away from Middle Eastern and Venezuelan oil. ${ }^{85}$ Moreover, from the perspective of Colombia, roughly 85 per cent of exported Colombian oil goes to the United States. ${ }^{86}$ The codependent relationship has functioned to further influence Colombian policies in favor of foreign multinationals and has been a major contributing factor in the privatization of the oil industry since the late 1970s.

In late 2001, Colombian President Andrés Pastrana's (1998-2002) issued a request to the United States for increased military assistance beyond counter-narcotics to deal with the insurgent threat. On February 5, 2002, President George W. Bush outlined a new military doctrine that called for military protection of strategic foreign sources of

\footnotetext{
${ }^{85}$ Andean South America is an oil hub for the United States. Venezuela is the U.S.'s biggest supplier, and there is concern that instability in Colombia could spill over. On the other hand, Venezuelan hostilities toward the U.S. since the election of Hugo Chávez as President in 1998 led the U.S. to seek secure alternative oil sources in Colombia; Dunning and Wirpsa 2004: 93

${ }^{86}$ Pearce 2005: 28, footnote
} 
natural resources. Military aid for the protection of natural resources is justified as part of the war against terrorism launched by the United States in $2001 .^{87}$

At that time, Plan Colombia, a 1999 joint U.S.-Colombian security effort, was already in place. Plan Colombia was implemented as a counter-narcotics program, although there is speculation that Plan Colombia was as much about protecting oil as it was about getting rid of illicit drugs. ${ }^{88}$ Regardless, it's clear that military aid to Colombia was greatly expanded after 2002. For fiscal year 2003, the Bush administration asked Congress to send an additional \$US98 million for military aid to Colombia, an increase of 22.3 percent of the annual request for Colombia. ${ }^{89}$ By 2004 , Colombia was the third largest world recipient of U.S. military aid in the world..$^{90}$

The largest share of U.S. military aid to Colombia since 2002 has been strategically deployed to protect the oil infrastructure in conflict regions, most especially the department of Arauca. President George W. Bush's 2002 aid package included the 'Colombian Pipeline Program', a program that earmarked military aid to protect the oil pipeline. The Pipeline Program supplied equipment including helicopters, and some 70 U.S. military advisers to train a Colombian army brigade to protect the strategic Caño

\footnotetext{
${ }^{87}$ Prior to 2001, United States' military aid to Colombia was limited to counter-narcotics. Since 2001, U.S. assistance to Colombia has expanded to include counterinsurgency and counter-terrorism based on the classification of Colombia's insurgent groups as terrorist organizations by the U.S. department of State; see M. Hodgson (2002) Oil Inflames Colombia's Civil War; Bush Seeks US\$98 million to help Bogotá Battle Guerrilla Pipeline Saboteurs, in the Christian Science Monitor, March 5, 2002; also see C.I Rueda (2002) E.U. cuidará sus intereses en Colombia, in El Tiempo, February 10, 2002

${ }^{88}$ Retired U.S. Special Forces Sergeant Stan Goff, who was active in training Colombian anti-narcotics troops, stated that the aim of Plan Colombia was "defending the operations of Occidental, British Petroleum, and Texas Petroleum, and securing control of future Colombian oilfields - the main interest of the United States is oil,"; Dunning and Wirpsa 2004: 96

89 ibid: 95

${ }^{90}$ ibid: $84-85$
} 
Limón-Coveñas oil pipeline, the Andean country's economic lifeline. ${ }^{91}$ During that year, United States Special Forces Green Berets trained 1,600 Colombian army soldiers as an anti-terrorist unit. ${ }^{92}$ The program targeted the first 110 miles of the pipeline located in the department of Arauca since this is where the majority of insurgent attacks took place. To that end, the XVIII Brigade of the Colombian army stationed in Arauca received approximately 2,000 additional troops and a mobile infantry skilled in surveillance and rapid deployment tactics. The pipeline security program cost the U.S. government $\$ 99$ million between 2002 and 2003. ${ }^{93}$

Within U.S. and Colombian policy circles, proponents of U.S. military assistance and intervention in petroleum producing regions of Colombia base their arguments on the importance of oil to the war effort. They argue that oil extraction will bring economic development and, more convincingly, revenue to the Colombian government that in turn will allow Colombia to fight and win the war. During a testimony to the U.S. Congress, Occidental's Vice President Laurence Mariage argued that military assistance to oil regions would strength the presence of the state leading to stability and economic growth. ${ }^{94}$ Hence, protecting Colombian oil is 'in the national interest' of Colombia and

\footnotetext{
${ }^{91}$ The program design and implementation was a joint effort involving the Department of State's (State) Bureau of Western Hemisphere Affairs and State's Bureau for International Narcotics and Law Enforcement Affairs, and various components of the Department of Defense; U.S. GAO Report GAO-05971

${ }^{92}$ Pearce 2005: 32; U.S. GAO Report GAO-05-971

${ }^{93}$ The helicopters cost $\$ 71$ million, and the remaining cost were for training and equipment. The helicopters are State assets provided under a no cost lease to the Colombian government; U.S. GAO Report GAO-05971; also see Dunning and Wirpsa 2004: 94-95

94 'Testimony of Laurence P. Meriage, Vice President of Executive Services and Public Affairs Occidental Oil and Gas Corporation, before the United States House of Representatives Government Reform Subcommittees on Criminal Justice, drug Policy and Human Resources, Hearing on Colombia, February 15,2000
} 
'for the common good'. ${ }^{95}$ Ironically, insurgents justify attacks on multinationals by evoking the national interest, as does the USO oil workers trade union in their struggles against privatization of the industry. ${ }^{96}$

Such arguments about the national interest demonstrate a critical distinction between licit and illicit commodities: licit war commodities are a source of revenue for the state (both internal and external) and therefore vital to the state's defense in the context of internal strife. Conversely, the state does not have access to rents generated by illicit commodities - although these commodities are a potential source of revenue for non-state actors. Hence, when licit commodity production in oil concentrated in Arauca, a conflict zone where it is vulnerable to insurgent sabotage and rent-seeking, the state sent in the military to defend the national interest.

\section{III. . The State Response: Military Protection and Public Goods}

“...For the Colombian government, the 'national interest' in protecting a major source of state revenues has provided new forms of discursive legitimacy for counter-insurgency actions, and more importantly has reshaped forms of military deployment with an increasing number of troops and resources deployed to protect energy infrastructure, "97

Oil is a major source of revenue for the State, and a critical resource that links the security interests of the United States to continued military support in Colombia. To protect its interest, beginning in the mid-1980s the Colombian government deployed its security apparatus to oil rich regions to protect oil companies from insurgent rent-seeking and popular pressure, while supplying public goods to incorporate the communities that

\footnotetext{
95 Dunning and Wirpsa 2004: 96

${ }^{96}$ Unión Sindical Obrera, La USO y su Lucha por una Política Nacionalista, paper presented at the second National Petroleum Congress, Bogotá, April 22-23, 2002

${ }^{97}$ Dunning and Wirpsa 2004: 85
} 
occupy the territories surrounding the oil infrastructure. The effort followed on an initial round of kidnappings in Arauca in 1983 in which the German contractor Mannesmann Ltd. reportedly paid the Domingo Laín front of the ELN US\$4 million for the safe return of three of their employees. The employees were returned unharmed and construction of the Caño Limón pipeline continued unabated as long as Occidental and Ecopetrol regularly transferred rents to Domingo Laín. The \$US4 million that Domingo Laín acquired from just one kidnapping operation was sufficient to initiate the re-emergence of the ELN from a nearly annihilated force to a formidable guerilla organization.

\section{The Colombian State and Military Defense in Oil Zones}

"The [Colombian] state receives 85 per cent of profits in the association contracts and therefore has the obligation to provide security for an operation, "98

In 2003, Colombia's national military budget reached historical levels at 5 per cent of GDP, as 'roughly equivalent to the country's revenues from primary commodity exports' at that time. ${ }^{99}$ Not surprisingly, oil-rich regions of Colombia have disproportionately benefited from the increased military spending. The state's first response to the discovery of oil in conflict-effected regions was to deploy the military. Security spending and military presence in Arauca and Casanare between 1993 and 2005 was far greater than in the three departments with the largest areas of illicit crops: Caquetá, Guaviare and Putumayo. Military spending was earmarked to "help the army to

\footnotetext{
${ }^{98}$ Statement made by Occidental President Stephen Newton as reported by El Tiempo, 4/21/1997, La guerrilla nos acorrala: OXY; article retrieved from CINEP newspaper archives, Bogotá, Colombia ${ }^{99}$ Richani 2005: 127
} 
dramatically increase troop presence in oil-producing regions' to form a permanent presence especially in the areas around the oil pipelines. ${ }^{100}$

In Arauca, militarization began with the construction of permanent military bases in the municipalities of Saravena, Batayon, and the department capital of Arauca in the mid-1980s. In addition, municipal courts were established and offices for fiscalías (public prosecutor). ${ }^{101}$ The military base in Saravena, which was closest to the oil infrastructure, was expanded in 2002 to provide facilities to house additional equipment, including helicopters that were provided from the United States. ${ }^{102}$ The military bases are all home to Colombia's 18th army brigade which is headquartered in Arauca. The $18^{\text {th }}$ Brigade is charged with security provisions in three departments: Arauca, Boyaca, and Norte de Santander. They provide roadway security, border control, conduct counter-narcotics operations, defend public order, and provide direct security for the Caño Limón pipeline. ${ }^{103}$ In 2002 , the $18^{\text {th }}$ Brigade was augmented with the newly established $5^{\text {th }}$ Brigade. $^{104}$

Indeed, the $18^{\text {th }}$ Brigade's presence in Arauca went far beyond vigilance of the pipeline to include regulation of the daily lives of the local population. To formalize the military occupation, Colombian President Alvaro Uribe declared Arauca a 'special security zone' where 'political liberties and freedoms are restricted'. ${ }^{105}$ This militarized response is a sharp contrast from the coca producing departments of the Western Amazon

\footnotetext{
100 Pearce 2005: 32; Dunning and Wirpsa 2004: 91

${ }^{101}$ Author interview with former municipal official on January 21, 2013 in Arauquita, Arauca, Colombia

102 U.S. Gao Report GAO-05-971

103 ibid

${ }^{104}$ U.S. Dept. of State 2002

105 Richani 2005: 129
} 
which were formally demilitarized and left under FARC control between 1999 and 2002. In Casanare, the lessons of Occidental Petroleum in Arauca resulted in an even quicker and stronger military response. When BP began its operations in Casanare in 1986, they immediately sought assistance from the Colombian armed forces for protection in order to avoid brokering deals with insurgents that would cut their profit margins and draw them into local conflicts. ${ }^{106}$

While data on the number of troops stationed in Arauca and Casanare is difficult to find, reports from army leaders consistently suggest that oil regions received the largest number of troops. In 1996, Army Commander Harold Bedoya reported that half of Colombia's troops were engaged in protecting oil and mining installations full-time, and a 1997 report from the Office of the People's Ombudsman in Colombia said that public spending on military security for oil installations was 'enormous'. Finally, in 2001, the commander of the XVIII Brigade in Arauca, Brigadier General Carlos Lemus, said that two thirds of Colombian troops were charged with protecting oil facilities. ${ }^{107}$

Data on the geographic distribution of national government security spending supports these statements that the military presence in oil producing regions has been significantly greater than in other conflict departments. Following the discovery of Caño Limón, the frontier department of Arauca was prioritized for security spending precisely because of the presence of oil. Between 1993 and 2003, per capita justice and security spending in Arauca and Casanare was $\$ 1,700,000$ and $\$ 1,600,000$ Colombian pesos respectively compared to the national average for the country of $\$ 900,000$ pesos per

\footnotetext{
${ }^{106}$ Pearce 2007: 229

${ }^{107}$ Dunning and Wirpsa 2004: 91
} 
capita. ${ }^{108}$ In comparison, justice and security spending in conflict departments with coca such as Caquetá, Putumayo, and Guaviare was considerably below the national average despite the presence of a criminal economy and numerically larger insurgent fronts compared to oil producing departments. ${ }^{109}$

Table 3.2 Colombia Justice and Security Spending in Conflict Departments, 1993-2005 110

\begin{tabular}{|c|c|}
\hline Department & $\begin{array}{c}\text { Justice and Security Spending per capita, } \\
\text { Colombian pesos 1993-2005 }\end{array}$ \\
\hline Arauca (oil; some coca) & $1,700,000$ \\
\hline Casanare (oil) & $1,600,000$ \\
\hline Caquetá (coca; some oil) & 380,000 \\
\hline Putumayo (coca; some oil) & 255,000 \\
\hline Guaviare (coca) & 54,000 \\
\hline National Average & 900,000 \\
\hline
\end{tabular}

Indeed, oil-producing regions have been at the center of national security policy in Colombia since the early 1990s. In 1991, the Colombian government devised a National Rehabilitation Program (PNR) that targeted among others the oil-producing municipality of Yopal in Casanare, the site of BP's oil installations. ${ }^{111}$ In addition, to secure the Caño Limón-Coveñas pipeline, the Colombian government implemented an infrastructure security strategy focusing in its first phase on the 110 miles of pipeline that transverse the department of Arauca where most insurgent attacks occurred. ${ }^{112}$ The strategy is a coordinated effort between the Colombian Army, police, and the Colombian Ministry of Justice Prosecutors' Office. As part of the first phase, the government sought

\footnotetext{
${ }^{108}$ Holmes and Gutiérrez de Piñeres 2012: 100

109 ibid: 113

110 ibid: $101,113,118$

111 Pearce 2007: 245

${ }^{112}$ U.S. GAO Report GAO-17-971
} 
the assistance of the United States Special Forces in training a counter-terrorism unit of 1,600 army soldiers in Arauca.

Indeed, as of 2001 the Infrastructure Protection Program, including the Pipe-line protection in Arauca, was controlled by a working group co-chaired by the Vice Minister for Defense and the Deputy Chief of Mission of the U.S. Embassy. With respect to Arauca, according to a 2002 report by the U.S. Department of State, the group meets regularly with the goals of coordinating training, re-establishing a police presence and expand the presence of the national government and the security communications infrastructure. $^{113}$

Indeed, the protection program was intended to complement the security policy of Colombian President Alvaro Uribe (2002-2010) called 'democratic security' which emphasized establishing an effective state presence as the key factor in winning the war against insurgents. Hence, the national government is also providing assistance of US\$650,000 a year to support the presence of a Prosecutor's office in Arauca. The Department of State reported that the increased state presence of the state's legal arm was successful, having resulted in the arrest of 39 suspected terrorists (insurgents) for attacks on the pipeline in just the first six months of 2002 compared to only three arrests between 1986 and $2001 .^{114}$

Following the initial militarization, the state attempted to better target strategic oil-producing regions by subcontracting its armed forces to multinational companies.

${ }^{113}$ U.S. Dept. of State 2002

114 ibid 
This meant that the oil companies would directly finance the military units that were providing for their protection. The state made up for the additional costs of subcontracts for oil companies by phasing out the war tax in 2001. Under the new arrangement, the oil companies still shouldered the costs of defense, but now more directly. To that end, the oil companies developed their own security departments, which were predominantly staffed with former military and security agency employees. ${ }^{115}$

Stephen Newton, President of Occidental in Colombia reported that Occidental had cooperative contracts with the Colombian Minister of Defense Gilberto Echeverri and the Commander of the armed forces, Harold Bedoya under which the oil multinational provided additional funds to improve protection of oil installations. According to Newton, the cooperative contracts between Occidental and the Colombian military are "...simply a way of defining the level of support for the military. It's for improving the food, providing transportation, but we are not buying weapons and bullets...we are not giving military support, but improving mobility and the lives of the soldiers,",116

The contract provides Occidental with the direct protection of 200 armed troops from the military and 90 armed police. In addition, in October of 1997 the Colombian Defense Ministry provided Occidental with two new counter-guerilla units in Arauca. In exchange for military protection, the three oil companies Shell, ECOPETROL, and Occidental transferred some US\$13 million to the Colombian military in 1997 alone. For

\footnotetext{
${ }^{115}$ Richani 2005: 127-128

${ }^{116}$ El Tiempo, 4/21/1997, La guerrilla nos acorrala: OXY; retrieved from the CINEP newspaper archives in Bogotá, Colombia
} 
Occidental's part, Newton reports that the oil company paid US\$3 million that year to provide food and helicopter transport for those sent to repair the oil pipeline after insurgent attacks. Months after the interview with Newton, a civilian contractor was killed when the ELN shot down one such helicopter alongside 20 military soldiers. ${ }^{117}$ Newton says that 10 percent of Occidental's costs in Colombia go to pay for security provisions, which was at that time in addition to the 'war tax' that Occidental was still paying to the national government for military protection. In total, Occidental spent US\$20 million on the war tax and cooperative contracts with the military in $1997 .{ }^{118}$

The Colombian government also provided for the defense of the oil industry through the legalization and then tactical support for civilian self-defense groups. State support for locally formed self-defense groups was formalized with the legalization of the Convivir in 1994. Self-defense groups have a long history in Colombia, but they became particularly active in the period after 1983 in response to insurgent predation against rural elites. Later, the self-defense groups were declared illegal because of a high level of human rights abuses. However, the severing of formal ties did not put an end to the selfdefense movement. These groups formed the basis for the paramilitary organizations that formed and worked closely with the national military during the 1990s.

${ }^{117}$ El Tiempo, 7/14/1997, Arauca, en medio de la Guerra; retrieved from the CINEP newspaper archives in Bogotá, Colombia

${ }_{118}$ In 2005, the U.S. GAO reported that each year Ecopetrol and Occidental contribute about $\$ 8.65$ million to help secure the Caño Limón pipeline in monies that go directly to the army, air force, and the department Prosecutor's Office. The money is reportedly used for military housing, food, transportation, communication, gasoline, and medical assistance. Occidental also built barrack facilities on an army base near the town of Saravena; El Tiempo, 4/21/1997, La guerrilla nos acorrala: OXY, retrieved from the CINEP newspaper archive in Bogotá, Colombia; U.S. Gao Report GAO Report 05-917 
Links between the military, paramilitary, and oil multinationals in Arauca and Casanare is particularly well documented. ${ }^{119}$ However, in Casanare, paramilitary forces eventually usurped territorial control from insurgents and began to extort BP in a manner remarkably similar to the ELN in Arauca. ${ }^{120}$ In Arauca, one local explains the link between the paramilitaries and the state as follows:

...Paramilitary activity was very protected, directed, and connected by the state. In Saravena, the [paramilitaries' came and the police protected them. In Tame in the same way they pass through military bases without any problem. Without any problem. They do roadblocks between the small towns with the presence of the police and military personnel. When they go into rural areas they first go the military. There was a near total alliance between the state and the paras. Very strong... ${ }^{121}$

Finally, beyond informal ties between the military and paramilitary forces, oil multinationals have sometimes contracted privates U.S. security firms to supplement Colombian military protection of their installations. British Petroleum contracted the Security Company Defense Systems Limited and its Israeli counterpart, Silver Shadow, to help protect its installations in the department of Antioquia, Colombia. The arrival of Silver Shadow coincided with a period of intense paramilitary violence and civilian massacres in the area, which some locals believed resulted from the security contractors' training of paramilitaries to engage in military and psychological strategies 'against the base of the guerillas'. ${ }^{122}$

\footnotetext{
${ }^{119}$ Pearce 2007: 230

${ }_{120}$ Pearce 2007: 230

${ }^{121}$ Author interview with former municipal official on January 21, 2012 in Arauquita, Arauca, Colombia

122 Dunning and Wirpsa 2004: 90-91
} 
Indeed, the Colombian government was initially tolerant of the presence of private security firms, but this became increasingly difficult due to suspicions that the contractors' were targeting civilians. A notorious example is the case of AirScan in Arauca. In 1997, Occidental petroleum contracted AirScan to provide surveillance of the pipeline, working closely with the Colombian military. In December of 1998, AirScan pilots accompanied a Colombian air force helicopter crew that allegedly dropped a cluster bomb on the village of Santo Domingo, about 30 miles south of the Caño Limón oil field in Arauca. The bomb killed 17 civilians, including seven children. Later, the Los Angeles Times reported that Occidental Petroleum "...provided crucial assistance to the operation...directly or through contractors', including 'troop transportation, planning facilities and fuel to the helicopter crew accused of dropping the bomb,"123 Partly as a result of the incident, contracts with AirScan were later transferred to the Colombian air force - an arrangement paid for by the national oil company Ecopetrol.

\section{The State and Public Goods}

Without a doubt, the Colombian state's presence in oil producing regions was predominantly military and focused on protection of economic interests. In 1997, the governor of Arauca Vicente Lozano reported that 58 per cent of public forces in the department are sent to protect the pipeline. ${ }^{124}$ Nonetheless, the Colombian government has also grown politically in these regions to a greater extent than in other frontier departments, including departments with significant illicit drug production. As Kaldor,

\footnotetext{
${ }^{123}$ Dunning and Wirpsa 2004: 91

124 el Teimpo, 7/14/1997, Arauca, en medio de la guerra; retrieved from the CINEP newspaper archives in Bogotá, Colombia
} 
Karl and Said explain, "the major investments that are needed to explore, extract, transport and process oil, and the agreements required with various parties to carry out and safeguard these investments, mean that a modicum of rule of law and legitimate authority is necessary to ensure uninterrupted flow," 125 To that end, the national government passed the National Law of Royalties in 1994 specifying that oil royalties be used by local governments for the provision of health, education, and infrastructure. By incorporating the populations that occupy the areas surrounding the oil pipelines, the state hoped to protect oil by curtailing popular support for insurgents with legal channels through which local communities could benefit from oil production.

As part of the 1994 legislation, not only local but national royalties would be earmarked for development spending, targeting regions rich in natural resources. Indeed, the national government's share of oil royalties is maintained as a distinct line-item in the country's national budget called the "National Royalty Fund". The Fund combines earnings from all active fields with about 20 per cent coming from Caño Limón in 2002. The Fund is managed by the National Royalty Commission which includes 13-members from the National Planning Department including the Director of the National Planning Department and the Ministers of Transportation, Economic Development and Mines and Energy along with the Governors of the six Colombian departments where oil is produced, the Mayor of Bogotá and one member that represents the Colombian

125 2007: 13 
municipalities with ports that export oil. The National Royalty Commission holds a monthly meeting to review the balances of National Royalty Fund. ${ }^{126}$

The National Royalty Fund, in addition to promoting environmentally responsible mining, also includes a mandate to provide investment for projects determined to be priorities in the development plans of the requesting regions. All territorial entities, including municipal and departmental governments along with regional development corporations, can request support from the National Royalty Fund. However, the military cannot make a direct request for financing (though the military might be an indirect recipient called on to implement or protect a financed project). ${ }^{127}$ Through the Fund, national royalties flow to the departments and municipalities where oil is excavated, earmarked for local development projects. The primary focus has been on social development project, specifically schools and healthcare. ${ }^{128}$

In fact, the Cravo Norte Association provides the department of Arauca with 90 per cent of revenues. Of that, 90 percent of funds are targeted for social investment as determined by a departmental development plan. In 2002, about half of the department's oil royalties were used to for programs to reduce infant mortality and build a social infrastructure, including health, education, and clean water. The remaining 10 per cent of royalties covers the costs of administering these programs and oversight. Likewise, at the municipal level 90 percent of royalties are dedicated to social spending, with about 75 per

\footnotetext{
${ }^{126}$ U.S. Dept. of State 2002

127 ibid

128 The royalties are managed by the Governor of Arauca and Mayor of Arauquita. The national government oversees the local budget and expenditures through the National Royalty Commission.
} 
cent going toward projects to provide a social infrastructure and the remainder for oversight and administrative costs. ${ }^{129}$

During a 12 month period between July 2001 and June 2003, a study by the United States Department of State found that expenditures of health, education and other social programs in the department of Arauca totaled US\$3 million drawn from national, departmental, and municipality royalties. The study documented thirty-three new schools and 11 medical clinics along the pipeline's path. In addition, oil royalties supported regular hospital service for the neighboring communities at the Caño Limón field. Most of the local children born between 1986 and 2002 were born at the hospital at Caño Limón. ${ }^{130}$

In addition to the national and local governments, the oil companies themselves also contribute to the deployment of public goods in the regions where they operate. The Cravo Norte Association in Arauca has transferred about US\$40 million for community development projects between 1986 and 2001. The expense was divided among the three entities that make up Cravo Norte: Ecopetrol, Occidental and Repsol. The programs directly benefited about 20,000 locals and indirectly benefited an additional 80,000 residents or about 26.7 per cent of the department's population. What is more, Ecopetrol spent an additional US\$1.5 million on 'complementary social programs' in $2001 .{ }^{131}$

Among the oil companies, Occidental Petroleum has provided the largest direct investment in social projects in the department of Arauca. The oil multinational claims to

\footnotetext{
${ }^{129}$ U.S. Dept. of State 2002

130 ibid

131 ibid
} 
provide locals with clean water, education, and parks. In 2001, Occidental established the foundation El Alcaraván, a local non-profit organization that provides funding for local economic development projects, including grants for agricultural cooperatives and small businesses, and 'experimental farms' where locals are taught techniques for cultivating non-traditional crops and animal husbandry. The program also provides a small sewing facility in Arauca that targets women heads of household and orphaned girls for training in small business development. As of 2002, about 14,000 families benefited from the projects. On average, the participants saw their monthly incomes increase from \$US74/month in 2000 to \$US105/month in 2001. ${ }^{132}$

Some of the oil companies' social investment is a direct result of insurgent predation, since insurgents extort a 'community tax' from oil companies to fund social projects and provide jobs as a mechanism for legitimizing insurgent predation and building a social base. ${ }^{133}$ However, in good part the oil companies' social contributions are motivated by pressure from the Colombian government. In 2002, then Finance Minister Juan Manuel Santos (the current President of Colombia) implored Ecopetrol to increase the resources that it devotes to local development projects, and in particular education and health. In a letter written that year by Santos to the United States Ambassador the future Colombian President said that he envisioned "as much as US $\$ 50$ million a year" being transferred from Ecopetrol to social projects in Arauca. ${ }^{134}$

\footnotetext{
${ }^{132}$ Occidental Petroleum Corporation, Improving Housing and Living Conditions in Colombia

${ }^{133}$ Richani 2002, 2005; Pearce 1995, 2007

${ }^{134}$ U.S. Dept. of State 2002
} 
Given the loss of oil revenues to conflict and corrupt politicians, major gains in the provision of state services and infrastructure have been slow. Nonetheless, available data and local testimonies suggest an expansion of the political reach of the central government in oil-producing regions. No reliable data on state capacity exists for Arauca and Casanare prior to the oil booms. However, national census data from 1993 and 1995 show an increase in the presence of the state institutions alongside the expansion of the oil industry, especially in Casanare. During this time, in Arauca and Casanare school attendance and enrollment in the national social security plan increased while poverty declined significantly.

Table 3.3 State Capacity in Arauca and Casanare, 1993-2005 ${ }^{135}$

\begin{tabular}{|c|c|c|}
\hline Indicator & Arauca & Casanare \\
\hline $\begin{array}{c}\text { Avg. years of School } \\
(1993-2005)\end{array}$ & 5.9 to 7.0 & 5.5 to 6.7 \\
\hline $\begin{array}{c}\text { Population enrolled in } \\
\text { Social Security (\%) } \\
(1996-2005)\end{array}$ & 10 to 70 & 33.7 to 95.6 \\
\hline $\begin{array}{c}\text { Poverty (\%) } \\
(1993-2005)\end{array}$ & 53.7 to 35.5 & 52.1 to 35.5 \\
\hline
\end{tabular}

Despite social spending, most of the popular sector in Arauca remained critical of the oil multinationals and their agenda. Locals express doubt that oil extraction in their backyards is good for local development. As far as they've seen, oil royalties are lost to corruption. At the same time, local testimonies from Arauca demonstrate an acknowledgement that oil coincided with an improvement in the quality of life. The

\footnotetext{
${ }^{135}$ Holmes and Gutiérrez de Piñeres 2012: 101, Table 4.1
} 
populations now have greater access to state institutions and basic public goods and they

attribute this, in some cases, to oil. Here are some local testimonies:

...A material infrastructure emerged with the emergence of oil. People say that it [oil] hasn't helped, that it only brought more problems. I say no. Yes, we have problems like everyone. But oil, I believe that because of this oil today we have electricity, today we have roads, today we have high schools, today we have [primary] schools in the neighborhoods, today we have health clinics-even if they don't work well-,today we have a hospital that runs regularly. I believe we have all of this because we have royalties..." "136

...The kids here practically all go to school. As far as health goes, that too. Yes, we have access to health care...life here, so to speak, we have good work, and it's not so heavy... ${ }^{137}$

In addition, a former municipal official from Arauca explained that the economic and political development that came from oil, and particularly the increase in educational and work opportunity, is a major contributing factor in the decline of the FARC and ELN in Arauca in addition to the military presence of the state:

...There were much more FARC and ELN ten years ago than [there are] today because there were more available [recruits] because reality was painful. Today... if I am a young person I am going to do my schooling, earn my diploma, very likely when I've completed the $11^{\text {th }}$ grade I am going to think differently. Am I going to choose to catch a bullet? Or, am I going to study at a University and continue living and have a family? This is something that doesn't allow for a rapid strengthening of the armed struggle. If I am young and I have my little farm, I have some humble means, then, surely I am going to think really hard, right?.. ${ }^{138}$

The data and testimony do not necessarily indicate an intention on the part of the national government to build political capacity in Arauca and Casanare. However, the

\footnotetext{
${ }^{136}$ Author interview with former municipal official on January 21, 2012 in Arauquita, Arauca, Colombia

${ }^{137}$ Author interview with member of the community action board on January 22, 2012 in Arauquita, Arauca

${ }^{138}$ Author interview with former municipal official on January 21, 2013 in Arauquita, Arauca
} 
fiscal decentralization of oil royalties in 1991, along with the 1994 Law of Royalties which earmarks local royalties for schools and hospitals, together indicate government intention to incorporate the frontier populations by investing oil royalties into public goods.

The increase in enrollment in social security is particularly notable. Oil is not labor intensive and could not have generated enough formal sector jobs to account for increased enrollment in social security. The more likely scenario is that state was formalizing rural wage workers with contracts and social security taxes because these sectors make up the traditional support base of the insurgents. Moreover, while we would expect some development to follow the influx of oil revenue, we do not see similar development gains in the coca-producing regions despite an equally lucrative resource 'boom'. The explanation for this is clear. Illicit rents did not reach the state by way of formal mechanisms, though some public officials benefited from the illicit booms through corruption. This is precisely the point: illicit rents did not support state military or political goals which structured the state's response to repress rather than protect the illicit economy.

\section{Conclusion}

It is not uncommon for oil multinationals in Colombia to protest the failure of the Colombian government to protect their installations from insurgent attacks. And yet, violence has hardly discouraged multinationals from doing business in Colombia. During the most violent decade of the 1990s, foreign direct investment in Colombia increased at an average rate of 55 percent annually from about US\$500 million in 1990 to US\$3,038 
million in $1998 .{ }^{139}$ Hence, from the perspective of the Colombian state which is highly dependent on oil revenues, security policy has been a success. Oil continues to flow in Colombia and multinationals continue to explore and exploit new reserves, even in some of the country's least hospitable regions. This speaks to the tremendous profitability of oil, which can be exploited by states along with multiple non-state armed actors and yet still produce a profit for oil companies.

The purpose of this chapter was to show that state reliance on oil makes the licit commodity a vital part of the national interest in Colombia that the government sought to protect by militarizing the region and promoting local development. The state's objective was to reclaim the territory and the lucrative resources within it for the national government. Ultimately, state deployment of military protection and social development projects limits the scope of insurgent rent-seeking vis-à-vis the oil sector to more coercive methods.

Over time, insurgent coercion in Arauca led to predatory authority wherein the insurgents' enforced their will on an unwilling population. In the next chapter, I explore the link between oil as a licit war commodity and the predatory authority exercised by the ELN front Domingo Laín in Arauca. There, the ELN exploited the oil sector by extorting, kidnapping, and violently attacking the oil infrastructure. The loss of lives and government revenue, the environmental damage caused by oil spills, and the contestation brought by ELN coercion resulted in predatory authority. By 2003, Arauca, one of the

\footnotetext{
${ }^{139}$ Richani 2005: 115, 125
} 
wealthiest departments in Colombia, was economically insolvent and overwhelmed by violence. 


\section{Chapter Four The ELN and Predatory Authority}

In 1984, the nearly defeated National Liberation Army (ELN) revived its organization with one single act of extortion. That year, the German contractor Mannesmann Anlagenbau A.G paid US\$2 million to the ELN's Domingo Laín front in exchange for the safe return of three kidnapped Mannesmann employees. ${ }^{1}$ The event marked the beginning of the ELN's coercive relationship with the oil industry in Arauca. Mannesmann was subcontracted by Ecopetrol and Occidental to construct a pipeline to carry oil from the Caño Limón field in Arauca to the Caribbean port of Coveñas. During the construction phase, Domingo Laín kidnapped employees and extorted rents from Mannesmann, as well as the oil companies Occidental and Ecopetrol. After the completion of the pipeline in 1986, the ELN used explosives to damage the pipeline in order to continue extracting rents. The Caño Limón pipeline was attacked by insurgents more than 1,000 times between 1986 and 2004 resulting in a loss of 2.9 billion barrels of crude oil. ${ }^{2}$ About 60 per cent of the attacks took place along the first 110 miles of pipeline in Arauca.

Prior to the 1980 s, oil windfalls were rarely associated with rebel profiteering in Colombia. ${ }^{3}$ Yet, during the 1990 s Colombian insurgents reaped about US\$140 million a year form oil-related extortions and kidnapping. ${ }^{4}$ This is less than the estimated US\$200-

\footnotetext{
${ }^{1}$ Dunning and Wirpsa 2004: 87; Richani 2005: 125

${ }^{2}$ Dunning and Wirpsa, 2004

${ }^{3}$ Prior to 1983 there was one significant insurgent attack on oil installations by the ELN on August 15, 1965; Guáqueta 2003: 83

${ }^{4}$ Dunning and Wirpsa 2004: 87
} 
500 million that insurgents extracted from the illicit drug trade, but arguably more significant since oil was at the same time financing state efforts to build military capacity. Certainly, oil rents were sufficient for the ELN to grow from about 40 members in 1984 to an estimated 3-6,000 members in 2004. ${ }^{5}$ The relationship between the ELN and the oil companies was initially cooperative, albeit tense. However, after the state militarized the region in defense of oil, the ELN declared war on foreign oil firms and Ecopetrol “...turning civilian personnel and workers as well as installations into rebel military targets, $" 6$ The department of Arauca was crippled by the loss of oil royalties. A predatory relationship developed wherein the community suffered the enormous cost of the ELN's activities and support for the ELN eroded.

With this chapter I provide empirical evidence that the state's response to oil as a licit war commodity creates conditions for insurgents to act as a predatory authority. To continue the narrative from the previous chapter, I focus on the oil-rich department of Arauca and the activities of the National Liberation Army (ELN). I argue that events in Arauca cannot be understood outside of national policies that targeted the oil sector for state protection and favorable economic policies. The empirical evidence for the chapter is based on regional ethnographies and testimonies, interviews with non-government institutions, the published literature, and interviews with community leaders and government officials that took place in Arauca in 2012. ${ }^{7}$

\footnotetext{
${ }^{5}$ Dunning and Wirpsa 2004: 87

6 ibid: 88

${ }^{7}$ Arauca was the only conflict zone that I visited in Colombia. On-site research was necessary because in contrast to the Amazonian region, there are few empirical studies of Arauca.
} 
The chapter is organized as follows. First, I describe the context in which the ELN emerged in Arauca and their activities there prior to oil. Second, I describe how oil brought the national government to Arauca and impacted the ELN resulting in a coercive economic strategy. Finally I link ELN coercion to predatory authority, citing as evidence a lack of popular support for the insurgents, civilian collaboration with armed rivals, civilian opposition to the creation of an ELN demilitarized zone, and the demobilization of the ELN's militant political wing in 1991.

I. Antecedents: The ELN and Arauca, 1964-1983

\section{The National Liberation Army (ELN), 1964-1978}

The National Liberation Army (ELN) is a popular insurgent organization in Colombia that formed in the 1960s and remains active today. As with most Cold War insurgencies in Latin America, the ELN was inspired by the 1959 Cuban Revolution and the foquismo theory of guerilla warfare championed by Argentine revolutionary and hero of the Cuban insurgency, Ernesto "Che" Guevara. ${ }^{8}$ Indeed, the founding commanders of the ELN had direct connections to Cuba, having traveled to the small Caribbean island in 1962 to be trained in the techniques and theories of guerilla warfare. ${ }^{9}$

When the ELN declared guerilla war on the Colombian government in 1964, they claimed to represent Colombia's excluded popular sectors, both rural and urban. Like the

\footnotetext{
${ }^{8}$ Focalism, or foquismo in Spanish, was a revolutionary philosophy and strategy formulated by the French intellectual Régis Debray based on the success of Ernesto Che Guevara in Cuba in 1959. Focalism calls for a highly militarized approach whereby rural space is conquered and a peasant army is organized to encircle and then invade urban centers.

${ }^{9}$ The extent of the Cuban government's involvement in the formation of the Colombian ELN is unknown. Testimonies of founding ELN members suggest support was limited to military training and indoctrination.
} 
FARC, the so-called elenos advocate for social justice for the poor and politically disenfranchised. However, the ELN had a much more heterogeneous social base that included urban social sectors. Hence, in addition to peasants, the ELN recruited from the urban proletariat and even groups within the middle and professional sectors, and progressive forces within the Catholic community. The ELN's broad social base manifested in a broader political agenda compared to the FARC. The ELN's political goals went beyond rural reform to include political inclusion and empowerment of organized labor, leftist political parties, and social movements.

The ELN's more heterogeneous social base is the result of its urban, middle class roots. The ELN's founding leaders emerged out of student uprisings that took place at the Industrial University of Santander (UIS) in the city of Bucaramanga, Colombia, during the 1950s. Indeed, the ELN was founded by rebellious middle class youths and intellectuals that embraced Marxist ideologies, including Roman Catholic priests inspired by Liberation Theology. ${ }^{10}$ The influence of progressive Catholicism was strong within the ELN, and many of the insurgents' sympathizers argue that Catholic morality explains the ELN's distinct economic strategy, including delayed involvement in the drug trade. However, religious morality cannot be reconciled with the ELN's propensity for

\footnotetext{
${ }^{10}$ The most famous ELN Priest Commanders are Camilo Torres Restrepo and Manual Pérez Martínez. Camilo Torres is the symbol of revolutionary struggle in Colombia. Torres died in combat with state forces in 1966. Father Manuel Pérez joined the ELN alongside Torres, and was ELN top commander from 1973 until his death in 1998.
} 
kidnapping and assassinating unarmed civilians, including high ranking members of the Catholic Church. ${ }^{11}$

Historically, the territorial strongholds of the ELN span three Colombian subregions: the Magdalena Medio region of north- central Colombia where the first ELN foci emerged in the department of Santander, the Caribbean region and especially the department of Bolívar, and the eastern plains departments of Arauca and Casanare. All of these areas were sites of natural resource exploration and extraction in the late $20^{\text {th }}$ century. In the Magdalena Valley, Arauca, and Casanare, the oil industry dominated the local economy. Likewise, in the department of Bolivar, the local economy revolves around gold, though illicit crop cultivation is a secondary activity is the south of the department.

The areas under ELN control are also considered 'colonization zones' structurally similar to the Amazonian and southern plains regions that were strongholds of the FARC during the same period between 1964 and 2004. Both frontiers were settled by peasants fleeing political violence and economic hardship. The Liberal guerilla groups that settled in the department of Santander during civil war the 1950s were particularly active in organized armed self-defense. ${ }^{12}$ The first ELN guerilla foci was made up of 16 peasant combatants in the rural municipality of San Vicente de Chucurí, Santander, a community

\footnotetext{
${ }^{11}$ On October 2, 1989 the ELN assassinated the Bishop of Arauca, Father Jesús Emilio Jaramillo Monsalve; El Tiempo, May 5, 1996, Radiografía del Domingo Laín, retrieved in the CINEP newspaper archives

${ }^{12}$ Rodríguez and Pizarro, 2005: 137
} 
well known in Colombia as home to some of the most well organized and militarily capable peasant self-defense groups of the La Violencia period. ${ }^{13}$

The ELN suffered early on from resource scarcity. Access to resources-or lack thereof- contributed to the ELN's military defeat in 1973 and re-emergence after 1983 with oil rents. Prior to oil, the ELN relied mostly on the peasant social base for 'revolutionary taxes' and supplies. In exchange, the elenos distributed Bonos de Esperanza Revolucionaria (Revolutionary Hope Bonds) worth twenty to thirty pesos per yucca or plantain to be paid after revolution was achieved. The bonds were worthless, and as the ELN grew the financial burden exceeded local resources and peasant communities began to resist. ${ }^{14}$ The ELN resorted to violence. Insurgent-civilian relations were 'based on fear, not respect'. ${ }^{15}$ If the peasants cooperated it was merely because “... they lived with the fear that the guerillas would hurt their families,"16

Hence, contrary to Jeremy Weinstein theory that resource accessibility causes insurgent predation toward civilians, the ELN demonstrates that resource scarcity can just as easily result in predatory resource extraction. Predatory relations with civilians left the ELN militarily and politically weak because it was impossible to gain the social support necessary for the ELN to remain in one area for any length of time. As a mobile guerilla organization, ELN fronts were loosely tied to regions, but within those regions they constantly moved in small groups. ELN leaders describe the early years of their

\footnotetext{
13 ibid

14 The ELN collected some additional rents by attacking local branches of the Agrarian Bank and robbing public entities. However, these were considered extraordinary financial resources that could not be counted on as regular income; Peñate 1998: 11; Medina 1997: 233

${ }^{15}$ Peñate 1998: 11-13

${ }^{16}$ Medina 1997: 238
} 
organization as 'extremely militaristic'. The lack of territorial specificity meant that the elenos were limited to attacking military and police targets. There was little interaction with local populations beyond the collection of rents, and practically no political mobilization. ${ }^{17}$

Without resources and popular support, the ELN experienced a major military defeat at the hands of the Colombian military in 1973 in the town of Anorí, Antioquia. The ELN entered Anorí as an invading force in search of resources and military targets. The ELN front that led the arrival into Anorí was the brothers Vásquez group, which included more than half the ELN's armed combatants. The brothers Vásquez launched an attack on the police posts and the local Agrarian Bank. ${ }^{18}$ But the military had been warned of the ELN's arrival by civilian collaborators and was able to overwhelm ELN forces. The critical point is that the peasant communities turned against the ELN, becoming informants for the state in order to avoid ELN predatory rent-seeking. After Anorí, the ELN suffered a series of military defeats reducing the insurgent organization from about 270 armed fighters to less than 70 dispersed into 4 or 5 self-directed fronts. ${ }^{19}$

The period following Anorí between 1974 and 1978 was the most violent in ELN history. Top Commander Fabio Vásquez understood the military defeats as the result of duplicity within the ranks. Capitulating on conspiracy theories, Vásquez began in a rather arbitrary manner to purge internal traitors. Following each military defeat, a meeting was called to identify the guilty and execute them. In the end, Vásquez ended up executing

\footnotetext{
17 Peñate 1998: 11

18 The Agrarian Bank (Caja Agraria) is a state-owned development bank that served as the primary conduit through which government loans and assistance were distributed to peasants.

${ }^{19}$ Medina 1997: 314
} 
most of the ELN founding leadership. ${ }^{20}$ Not surprisingly, the purging further weakened and divided the insurgent organization. An internal war ensued that resulted in Vásquez's departure to Cuba where he was officially relieved of his duties in 1976 . However, even in the absence of Vásquez the purging continued until 1978. The ELN practically annihilated itself. $^{21}$

After 1978, the remaining members of the ELN dispersed and fled to jungle regions of Bolivar, North Santander, and Arauca to hide amongst the peasant population and remain dormant for half a decade. With little resources and almost no social support, the guerilla group could hardly overcome internal divisions. ${ }^{22}$ However, after 1983, the ELN reemerged practically overnight from a loose network of guerilla fronts to a militarily formidable guerilla organization of over 5,000 members. The ELN's transformation is linked to the discovery of crude oil in Arauca where the local ELN front Domingo Laín kidnapped, extorted and attacked in order to access oil rents. To explain the transformative effects of oil on Domingo Laín and the development of predatory relations, I begin with the department of Arauca and the insurgents activities there prior to oil.

\section{Domingo Laín, 1980-1983}

The ELN first announced its presence in Arauca in 1980. After the period of military defeat and internal purging between 1973 and 1978, the remaining ELN

\footnotetext{
${ }^{20}$ Among the executed where the ELN's original founders Victor Medina Mora, Heliodoro Ochoa, Julio Cesar Cortes, and Jaime Arenas; Harnecker 1988: 27-28; Ruiz 2001: 188

${ }^{21}$ Peñate 1998: 14

${ }^{22}$ The urban faction favored political work while the rural faction favored military struggle based on the foquista theory. After 1983, the ELN adopted both approaches, increasing political work within legal organizations while expanding military activities; Peñate 1998: 14-16
} 
members dispersed into 36 autonomous units occupying the jungle areas of the Caribbean and Eastern plains of Colombia. One group of about fifteen ELN combatants arrived to the region of Sarare, Arauca, where they formed the Domingo Laín front. In 1980, Domingo Laín carried out their first military operation by taking over a small inspection station in the municipality of Tame, Arauca. ${ }^{23}$ By 1983 Domingo Laín had developed a considerable peasant following in the four municipalities that constitute the Sarare region: Tame, Saravena, Fortune, and Arauquita. ${ }^{24}$

Prior to the advent of oil production, Domingo Laín financed their operations in Arauca with small-scale kidnappings of ranchers and traditional elites called llaneros in the more affluent llanos plains region adjacent to Sarare and in Venezuela. State presence, including the police and military, was scant. In fact, Venezuela maintained a stronger military presence at the border, although even this was insufficient to protect the local population from insurgent kidnappings. The limited resources obtained by Domingo Laín based on this strategy were not remitted to help the organization as a whole, but instead were used to grow and expand the Domingo Laín front in Arauca. However, growth in Arauca and at the national level was very modest prior to 1983. In fact, the ELN was so poor that the organization had to request funds from another insurgent group, the $19^{\text {th }}$ of April Movement (M-19), in order to subsist. ${ }^{25}$

\footnotetext{
${ }^{23}$ The small inspection stations were sometimes the only local state institutions in parts of Colombia's national territory; El Tiempo, May 5, 1996 from CINEP newspaper archives

${ }^{24}$ Author interview with former municipal official, January 20, 2012, Arauquita, Arauca, Colombia

${ }^{25}$ The M-19 was a Colombian insurgent group with an urban, intellectual, and middle class base that demobilized in 1991; Harnecker 1988: 23
} 
However weak, Domingo Laín nonetheless obtained a foothold in Arauca prior to oil by embedding within traditional patron-client political networks and forging a coalition with the peasant colonos in Sarare. A newly arrived population, the colonos of Sarare broke the balance of power between Liberal and Conservative forces in the region. Hence, the peasants' electoral influence was considerable despite their lack of resources. Domingo Laín successfully formed a coalition with the peasant sector in order to exercise bargaining power vis-à-vis regional political elites.

To win over the peasants, Domingo Laín imitated the FARC's longtime strategy of trabajo de masas (mass works). In essence, Domingo Laín influenced (with guns) INCORA's distribution of public investment and credit in the colonization zone of Sarare. The insurgents also helps peasant leaders to organize civic strikes and land invasions, and used the threat of force to control local Community Action Boards (JACs) so that resources were distributed in favor of the peasant colonizers. ${ }^{26}$ Hence, in the beginning the peasants of Sarare benefited from Domingo Laín activities and were a strong local support base for the emerging insurgent front. The peasant communities provided Domingo Laín with food, supplies, information, and recruits. Indeed, with the exception of the first fifteen urbanites who arrived as outsiders, most members of Domingo Laín were local recruits. They were, as one local explained, 'sons of Arauca':

"the colonizers considered the guerilla the only [authority], it was like the foundations of a state or government...It was the guerilla that always solved problems within families, marital problems, mediocrities, conflicts, crime, credit, roads, public works, and all. You see? And they had a strong influence because they organized economic development. They organized the

${ }^{26}$ Peñate 1998: 20-21 
community, coming out of the gaps, constructing roads and schools strengthening education. They led powerful strikes and they organized civil society. There was at one time 15 or 10 thousand people in the town center asking for communication and roads and there was nothing. In a way they [the insurgents] were instrumental in this sense. Well, then, the other side was that this generated an air of respect. They did not permit common crime. They did not permit common crime because they [the insurgents] would find and punish them. There was a death penalty. In some cases for example, for killing. Yes. In some way it was like a State like the United States, no? All of this obliged a respect [for the insurgents] that eliminated social problems, "27

Indeed, insurgent relations with the peasant sector were good prior to oil. Moreover, Domingo Laín also forged cooperative relations with the political elite. Liberal party bosses exchanged private goods and programs to benefit the peasant sector in exchange for the ELN's mobilization of the peasant vote. ${ }^{28}$ In this way, Liberal party candidates capitalized on the presence of insurgents for political gain and in exchange ensured popular support for the insurgents. ${ }^{29}$ Later, the FARC entered Arauca and began to co-opt the political opposition, which often turned political competitions violent. ${ }^{30}$ In this scenario, Sarare was the critical zone because it is the region with the fastest growing population. As long as Domingo Laín controlled Sarare, which it did until the early 1990s, the ELN was the dominant armed actor in Arauca.

Indeed, when oil was discovered in Arauca in 1983, Domingo Laín already formed strong ties with both peasants and a faction of the political elite. However, oil

${ }^{27}$ Author interview with former government official on January 20, 2012, in Arauquita, Arauca, Colombia

${ }^{28}$ Pearce 2005: 40

${ }^{29}$ Kalyvas (2006) finds that civilian populations capitalize on contestation between state and insurgent forces by denouncing local enemies and neighbors as supporters of the other side in order to carry out personal vendettas.

${ }^{30}$ The FARC competed against the Liberal party for political control through an alliance with the Patriotic Union (UP). During the 1990s, the FARC and the ELN battled each other through violent electoral competition for control of the Sarare region while at the same time forming a solid block against traditional elites; Pearce 2005: 43-45 
transformed and corroded insurgent-civilian relations. The impact of oil rents on Domingo Laín was rapid and profound. The insurgent front grew from just 15 members in 1979 to the most powerful ELN war front. ${ }^{31}$ As of 1996, Domingo Laín had150 armed combatants divided into nine commissions and a special group called the Simacota Company with an additional 90 to 120 combatants. By that point, Domingo Laín was highly capable of attacks on military posts, including an attack across borders on a military installation in Cararabo, Venezuela in March of 1995. As of 1997, it was reported that ELN forces in Arauca had reached 300 armed combatants with a presence in all seven of the department's municipalities as well as parts of the neighboring departments of Boyacá and Casanare, Colombia’s other oil rich department. ${ }^{32}$

During the critical decade of the 90s, Domingo Laín was under the leadership of Armel Robles Riaño (alias El Chino), a local recruit from Arauca who joined the organization in 1986. El Chino led Domingo Laín during its most violent period. He oversaw a critical shift in the insurgents' economic strategy in which violent targeting of the oil industry, including the oil companies and their employees, was central to resource extraction. Indeed, oil was a tremendously lucrative and obstructable resource, and in Arauca it was discovered practically on the doorstep of Domingo Laín.

\section{II. . Domingo Laín and Coercive Rent-Seeking in Arauca}

In 1983, the ELN came together to hold the National Reunion of the Heroes and Martyrs of Anorí meeting, which marked the beginning of a new phase of growth and re-

\footnotetext{
${ }^{31}$ Peñate 1998: 19

${ }^{32}$ El Tiempo, 7/14/1997, Arauca, en medio de la guerra; retrieved from CINEP newspaper archives; El Tiempo, Radiografía del Domingo Laín, May 5, 1996 retrieved from CINEP newspaper archives
} 
consolidation for the defeated insurgent organization. ${ }^{33}$ As part of their new strategy, the ELN was committed to not repeating mistakes. Above all, the remaining ELN members understood the 1973 defeat at Anorí as the result of bad relations with the local populations who had turned on the ELN because of the insurgents' predatory resource extraction prior to 1978 . Hence, the discussion in 1983 revolved around finding new ways to finance the insurgency without relying on peasant support. Indeed, the 'new' ELN put special emphasis on good relations with the civilian populations as a matter of survival, which in turn meant devising an economic strategy that would eliminate dependence on the insurgents' social base.

Certainly, the ELN and Domingo Laín never explicitly embraced coercion or violence as part of their economic strategy. Quite the opposite. Domingo Laín justified targeting the oil industry by framing violence as an attack on the state and imperialism in defense of the interests of the local population. Yet, Domingo Laín's activities in Arauca turned coercive and ended up corroding the insurgents' relationship with the civilian population. Domingo Laín's approach to oil was not always so violent. In the beginning, Domingo Laín established a protection racket with only isolated incidences of violence. Between 1983 and 1986, the oil companies cooperated in paying rents to insurgents. However, when state security forces forged ties with the oil companies and militarized Arauca on their behalf, cooperative relations between the oil companies and insurgents collapsed. The oil companies began paying protection rents to the state and resisting insurgent extortions with violent consequences.

\footnotetext{
${ }^{33}$ Ruiz 2001: 187
} 


\section{The Protection Racket, 1983-1986}

In a classic study of conflict in Arauca, Colombia, Andrés Peñate argued that the ELN found in the petroleum sector "...the form, although corrupt, of bringing together the armed struggle with the interests of a sector of the population," ${ }^{34}$ Access to oil rents eliminated the need to forcibly extract resources from the peasant social base. At the same time, the elenos were able to justify their actions by appealing to the nationalist conflicts surrounding foreign-controlled oil, arguing that they were not stealing but actually protecting Colombia's natural resources from imperialist tendencies. Between 1983 and 1986, Domingo Laín's relations with the oil companies was relatively cooperative, albeit tense. The companies paid rents to the insurgents and in exchange they were able to do business in the zone and still secure enormous profits.

Nazih Richani identifies four modalities of rent extraction used by insurgents to exploit the oil industry in Colombia: a direct tax, a community tax, subcontracts, and the retention tax. ${ }^{35}$ The direct tax is essentially a racket through which oil companies pay insurgents and in turn expect that the insurgents will not attack their installations and personnel. The community tax forces oil companies to fund local development initiatives. In essence, it is a transfer of royalties to the peasant sector. Subcontracts force oil companies to favor certain contractors for public works and installation repairs projects. In turn, the contractors provide employment to insurgent supporters and a payoff to the

\footnotetext{
${ }^{34}$ Peñate 1998: 16

${ }^{35}$ Richani 2005
} 
insurgents. Finally, the retention tax is the most lucrative mode of resource extraction wherein insurgents kidnap high ranking employees of the companies for ransom. ${ }^{36}$

Between 1983 and 1986, Domingo Laín captured rents vis-à-vis the oil industry in Arauca using all four of Richani's methods. Rents from direct and retention taxes generated by far the most income for the insurgents. Domingo Laín began collecting direct taxes from the oil multinationals and their subcontractors as early as 1983 . To do so, the insurgents strategically mediated between multinationals and the local peasant sector, two groups with conflicting interests with regards to the distribution of oil royalties and land use.

Violence erupted in Arauca as soon as the German engineering firm Mannesmann Anlagenbau A.G, a subcontractor of Occidental petroleum and Ecopetrol, began construction on the Caño-Limón pipeline in 1983. To avoid entering Venezuelan territory, the oil companies were obligated to design the route of oil excavation through Sarare, the territory of Domingo Laín. ${ }^{37}$ Before any pipeline was even laid, local strikes and protests in Sarara resulted in the deaths of four peasants and the retributory assassination of four oil workers. ${ }^{38}$

Domingo Laín intervened in the conflict in defense of the peasants, but in a way that generated rents for the insurgent organization. In this way, Domingo Laín's strategy was remarkably similar to the FARC's initial interactions with the drug trade. The FARC was also as an arbiter between economic elites and popular forces, though in coca regions

\footnotetext{
36 ibid: 125-126

${ }^{37}$ Peñate 1998: 24

38 ibid: 19
} 
the main conflict was between peasant cultivators and drug traffickers. In both cases, the ELN and the FARC accessed rents by resolving conflicts in favor of the disadvantaged peasants and in return claiming a share of profits.

Domingo Laín's first intervention took place in 1984, shortly after violence erupted between peasants and the oil companies. Domingo Laín kidnapped four Mannesmann employees, and released them only after Mannesmann paid an estimated US\$2 million dollars retention tax. In one act of extortion, Domingo Laín demonstrated their capacity to inflict harm on the company's project and employees. Between 1984 and 1986 Domingo Laín successfully convinced Mannesmann to transfer an additional US\$18 million in direct taxes to the insurgents. In exchange, Domingo Laín allowed Mannesmann to complete the Caño Limón pipeline, a project worth US\$169 million, without interference from insurgents or peasant protestors. ${ }^{39}$ Mannesmann also agreed to pay a community tax for local programs and even give preferential treatment for jobs to ELN supporters. As long as Mannesmann cooperated in meeting the demands, the work was unobstructed. ${ }^{40}$

As the first multinational to begin constructing the oil infrastructure, Mannesmann was the first target of ELN rent collection in Arauca. However, in the long term, it was the state-owned oil company Ecopetrol and the multinational Occidental that provided a regular source of income for Domingo Laín. Occidental had long time horizons in Arauca, and regularly paid a direct tax to Domingo Laín in exchange for the safety of its installations and employees. In fact, evidence suggests Occidental was pro-

\footnotetext{
${ }^{39}$ Richani 2005: 126

${ }^{40}$ Peñate 1998: 24-25
} 
active in seeking out the insurgents to offer a payout. In early 1984, the petroleum multinational sent representatives to transact with representatives of Domingo Laín, and speculation suggests Occidental may have paid the insurgents 4 million dollars to guarantee the safety of their installations in Arauca. In addition, Occidental reportedly agreed to make an annual 'charity donation' to the local Church for social projects. ${ }^{41}$

Hence, less than a year after the discovery of oil at Caño Limón, Domingo Laín had established a profitable protection racket in Arauca collecting direct taxes from both Occidental and eventually Ecopetrol. Arguably, Domingo Laín was providing the oil companies with legitimate protection against the insurgent mobilized peasant groups that were opposed to the oil companies' activities in Arauca. Indeed, in 1984 oil production was brought to a halt by a civic strike in which the peasant community demanded all types of infrastructure. In response, Occidental organized a community program office, but the office very quickly began to receive threats. Domingo Laín mediate the conflict, protecting the oil installations from peasant strikes as long as the insurgents received some payoff from the oil companies. Occidental Petroleum's Vice-President for Executive Services and Public Affairs, Lawrence P. Meriage, testified that the company's contractors pay a regular 'war tax' to the rebels. ${ }^{42}$

For their part, the peasant communities discovered that the elenos were the best means to secure benefits from the oil industry, and they were willing to abide by some of Domingo Laín's rules in exchange. Indeed, Domingo Laín attempted to deliver public goods in order to build local support, but in a manner that was indirect and coerced. After

\footnotetext{
${ }^{41}$ ibid

${ }^{42}$ Dunning and Wirpsa 2004: 87; Richani 2005:125
} 
1983, the 'community tax' was a regular expenditure for Occidental and Ecopetrol in Arauca that secured the support and cooperation of the peasant sector for Domingo Laín. In Sarare, Occidental's 'community tax' funded a number of local public works projects including schools, clinics, supplying computers, children's playgrounds, and paved roads. One research reports that the oil companies were forced to fund "everything from chess tournaments and fish ponds, to housing projects and University scholarships," ${ }^{43}$ The amount and nature of the community tax varied and was negotiated by the oil company and a 'targeted community representative' who was an associate of the ELN. ${ }^{44}$ To carry out the public works projects, the oil companies subcontracted to ELN-owned enterprises or else the guerillas received five per cent on subcontracts with other enterprises. ${ }^{45}$

By 'intermediating' the transfer of resources for public works projects from the oil companies to the communities affected by the pipeline, Domingo Laín expanded their territorial domain along the extension of the pipeline from Arauca to the department of César in the Caribbean region. Along the way, Domingo Laín formed new fronts that together formed the Northeast War Front, largest and most powerful regional bloque of the ELN. ${ }^{46}$

In sum, during the first three years following the discovery of the oil field in 1983 the ELN front Domingo Laín had established a cooperative, albeit fragile, relationship with the oil industry. Based on the arrangement, Domingo Laín secured regular 'protection rents' and services for the peasant sector in exchange for allowing the oil

${ }^{43}$ Dunnig and Wirpsa 2004: 101

${ }^{44}$ Richani 2004: 70

${ }^{45}$ ibid

${ }^{46}$ Peñate 1998: 25-26 
multinationals and their subcontractors to do business in the zone. In this way, the ELN arbitrated the conflict between peasants and the oil companies in a manner that paralleled the FARC's arbitration between peasant cultivators and narcotics traffickers. However, while the FARC provided economic and military protection as a public good, Domingo Laín did not provide protection nor directly provide public goods. Instead, Domingo Laín embedded within existing power structures to influence the distribution of oil royalties, thereby creating private goods for peasant supporters. Meanwhile, the Colombian government militarized by levying its own direct tax, the war tax, on oil companies. The state's strategy in Arauca broke the cooperative exchange between foreign multinationals and insurgents resulting in greater violence.

\section{Increased Violence, 1986-2004}

In 1986 the ELN launched a campaign called 'Wake up Colombia, they are stealing the petroleum' ${ }^{47}$ With their campaign, the ELN constructed a national discourse over petroleum, justifying violence against the oil industry as a form of political protest against foreign control of Colombia's national resources. ${ }^{48}$ Indeed, after 1986 Domingo Laín stepped up their strategy for exploiting the oil industry to include more violent tactics, most especially attacking the oil infrastructure with explosives. In addition, Domingo Laín began to target contract workers sent to repair the pipelines, and to extend their kidnapping activities to include 'large scale' operations of dozens and sometimes hundreds of oil company contractor employees.

\footnotetext{
${ }^{47}$ Pearce 2005

${ }^{48}$ Pearce 2005: 25-26; Guáqueta 2003: 84
} 
Domingo Laín needed to reconcile violent rent-seeking with their political goals in order to maintain legitimacy vis-à-vis their social support base which included peasants, organized workers, and religious communities. To that end, the insurgents argued that it was better to spill the oil than allow Colombia's riches to be controlled by imperialists. However, Domingo Laín's predacious rent-seeking generated costs paid by multiple actors, not just foreign multinationals. As a result of Domingo Laín, the national government lost billions in royalties, and departmental and municipal governments went bankrupt due to the exacerbated problem of corruption. In addition, unarmed civilians lost their lives as a result of the explosions, and sometimes their livelihoods due to oil spills that polluted river water and left farm lands unproductive.

Under the initial arrangement in which oil multinationals transferred protection rents and community taxes, the costs of the ELN's rent-seeking were mostly limited to the oil sector while in fact local communities benefited. However, once the ELN began attacking the oil infrastructure, the costs extended to other social sectors, including the insurgents' support base. Between 1986 and 1998 the infamous Caño Limón-Coveñas pipeline was attacked by insurgents 450 times. Of the 450 attacks, 216 or 40 percent occurred in the department of Arauca. ${ }^{49}$ The insurgents attacked the pipeline by planting dynamite underground that would explode and produce damage and leaks that needed repairs. The repairs brought new subcontractors to the region that were then targeted by the ELN for rents.

${ }^{49}$ El Tiempo, 7/1/1998, Arauca está al borde de la quiebra: gobernador; retrieved from CINEP newspaper archives in Bogotá, Colombia; *statistics reported by ECOPETROL 
Chart 4.1 Oil Production and Insurgent Attacks in Colombia, 1986-1997

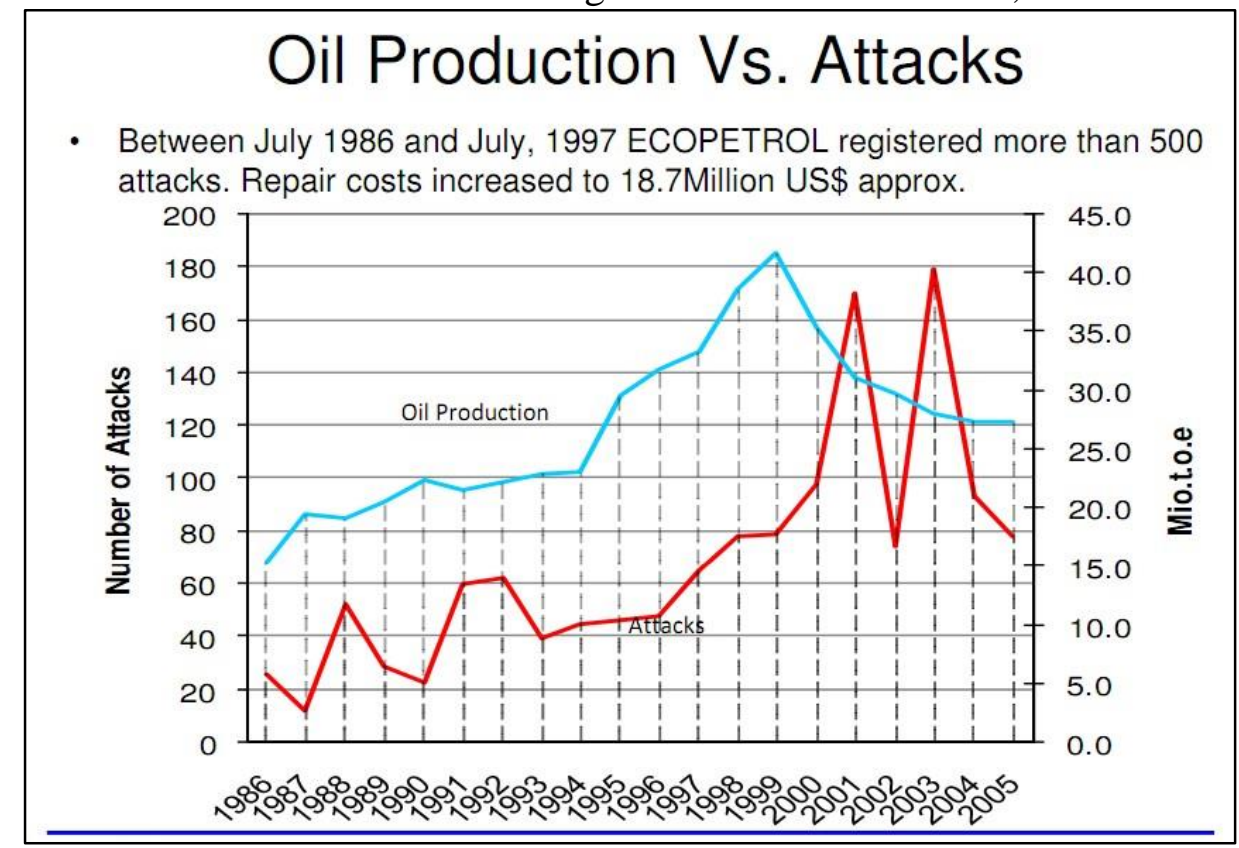

Indeed, the attacks on the pipeline that began in 1986 represented a qualitative change in the way Domingo Laín accessed oil rents. The new strategy was in part a reaction to increased military protection of the oil companies, which had successfully undermined the cooperative protection racket through which Domingo Laín initially secured direct taxes.

${ }^{50}$ Occidental Petroleum: http://www.plawlotic.com/?p=442 
Chart 4.2 Insurgent Attacks on the Caño-Limón Pipeline, 1988-1997 ${ }^{51}$

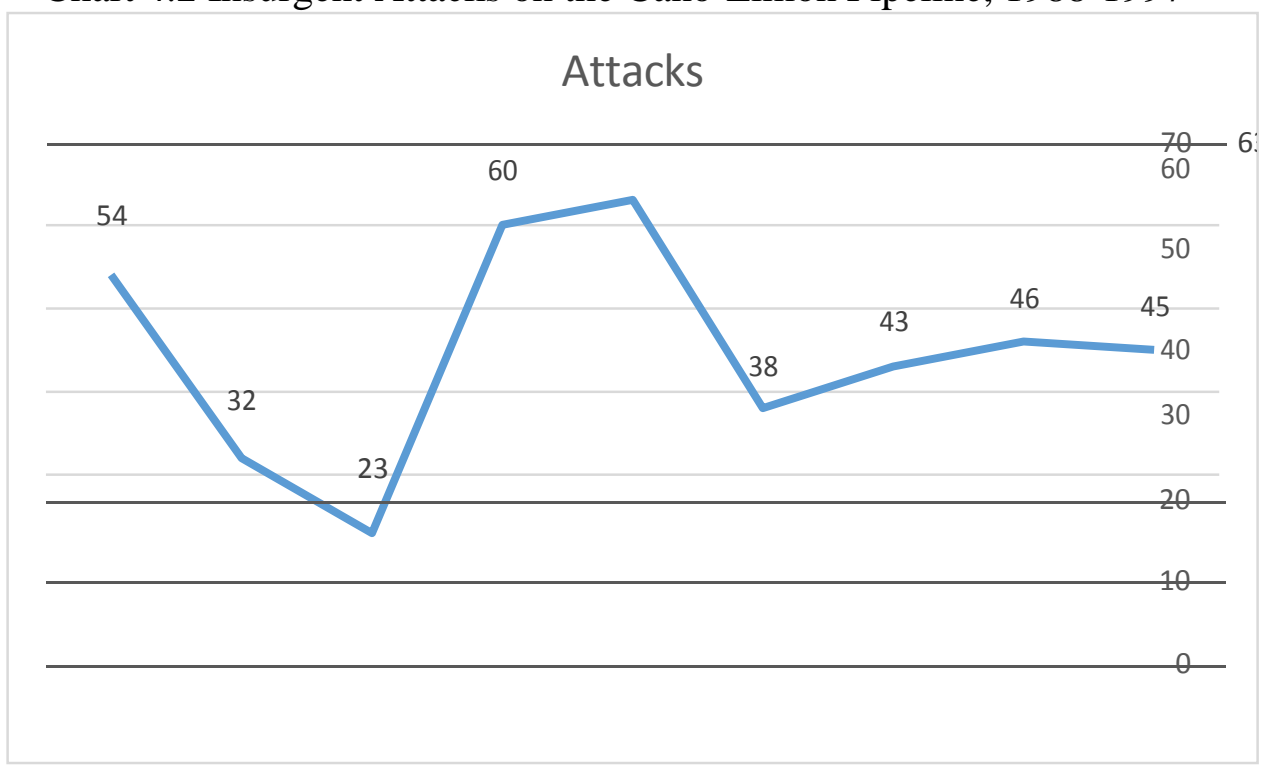

Domingo Laín's relationship with the subcontractors hired to repair the damaged pipeline was at the center of their economic strategy. After attacking the pipelines, Domingo Laín influenced which companies were subcontracted to prepare the pipeline via two routes: government insiders and violence. First, Domingo Laín planted insurgent informants inside the public offices that controlled public works contracts. After receiving the job with the help of Domingo Laín, the subcontractors paid a percentage to the insurgents and also to the public official. A 2003 investigation by the National Royalties Commission and the Prosecutor General's Office revealed that these types of 'deals' between insurgents and contractors carried out by way of corrupt public officials were alarmingly regular. The investigation led to federal intervention in the management

${ }^{51}$ El Tiempo, 4/21/1997, La guerrilla nos acorrala: OXY; retrieved from CINEP's newspaper archives in Bogotá, Colombia 
of royalty payments to Arauca. ${ }^{52}$ According to a local government official, Occidental Petroleum paid US\$1.3 billion in royalties to municipal governments between 1986 and 2005 of which US\$390 million ended up going to insurgents through subcontracts. ${ }^{53}$

One contributing factor behind the ELN's infiltration of local government after 1986 is institutional and therefore exogenous to my argument. Between 1986 and 1991, Colombia underwent a process of electoral and fiscal decentralization. A new Constitution went into effect in 1991 that decentralized power to municipal and departmental governments by allowing for local election of mayors and governors (previously appointed by Congressional Representatives in Bogotá) and decentralizing fiscal control, which meant the departments and municipalities would have access to oil royalties and decisions on public expenditures. ${ }^{54}$ The confluence of traditional clientelism, petroleum wealth, fiscal and electoral decentralization, and insurgency created perfect the conditions for armed clientelism to develop in Colombian regions rich in natural resources. "Funds were suddenly available in a territory where the politics of wealth and power was based in clientelistic relations with the right to vote,"

Nonetheless, while fiscal decentralization contributed to the ELN's infiltration of the public sector, military protection of oil multinationals was a major factor in sending the insurgents searching for other means to access oil rents. What is more, decentralization alone does not explain why the ELN became increasingly violent against

\footnotetext{
${ }^{52}$ Dunning and Wirpsa 2004: 88

${ }^{53}$ Richani 2005: 125

${ }^{54}$ Guáqueta 2003: 81

55 Pearce 2005: 41; Guáqueta 2003: 84; the term armed clientelism was coined by Colombian scholar Malcolm Deas
} 
public officials who failed to meet expectations. According to local testimony, Domingo Laín targeting of political leaders went beyond the logic of clientelism. The ELN began kidnapping and assassinating elected officials in Arauca, even the insurgents' own political allies, for their role in supporting militarization or for supposed misuse of public monies. ${ }^{56}$

Hence, not only did Domingo Laín control subcontracts, but they also controlled political candidates as a means to influence subcontracts, access oil royalties, and control public expenditures such that the peasant sector continued to receive a greater share of the benefits of oil extraction. After all, Domingo Laín's power in the region was based on their influence over the peasant sector and, by extension, the peasant vote. Hence, the elenos had to continue providing material goods to the peasant social base which required some influence over the use of oil royalties at the local level. In essence, Domingo Laín commanders transformed into local patrons that mobilized peasant support behind candidates and officials in exchange for a share of oil royalties and influence over public spending on small public works projects in favor of families, Community Action Boards, and neighborhoods that were loyal to the ELN. ${ }^{57}$

Second, the elenos used violence against unarmed civilian contractors and workers to influence subcontracts for pipeline repairs. To secure the labor contracts for their supporters, part of Domingo Laín's strategy was to threaten and attack civilian

\footnotetext{
${ }^{56}$ In 1995, the ELN kidnapped the Mayor of Tame, María Helena Molina and held her for several days as part of a 'political trial' against the Mayor for supposedly robbing 1,200 million pesos from the municipality. Molina was eventually turned over to the Red Cross having demonstrated her innocence; $E l$ Tiempo, April 12, 1996, El Eln 'enjuiciará' a alcaldesa de Tama; El Tiempo, October 12, 1996, Eln le hizo un 'juicio' a alcaldesa'. Both articles retrieved in the CINEP newspaper archives.

${ }^{57}$ Guáqueta 2003: 84; Peñate 1998:17
} 
contractors sent to do repairs. Domingo Laín was notorious for shooting down helicopters and trucks with civilian and military personnel en route to repair installations. During a 1997 investigation by El Tiempo, the Mayor of the municipality of Saravena, José Arévalo, reported that officials had deactivated a bomb and discovered five more that were destined for attacks on machinery for repairing the pipeline. One local truck driver that transported machinery for repairs told reporters he often confronted ELN roadblocks set up to detain contract workers. The driver further reported the elenos recently assaulted him on the way to a job site, and attempted to set fire to his truck. ${ }^{58}$

In addition to receiving payoffs, controlling subcontracts also allowed Domingo Laín to regulate the need for labor to carry out the reconstruction, offering these jobs to their supporters and in turn gaining more support from the peasant sector. In other words, Domingo Laín found that attacking the oil pipelines benefited them politically and financially. ${ }^{59}$ But as a strategy it was not sustainable over the long-term. The costs incurred to the community in losses of royalties and oil, damage to waterways and land caused by the spills, and the loss of human life due to the explosions, retentions, and targeting of subcontractors was far greater than the gains, even for the peasant communities.

Finally, the ELN's reliance on kidnapping expanded. Losses in direct taxes were replaced by increased retention taxes in response to militarization of the region. A study carried out between 1995 and 2000 shows that in Colombia insurgents obtained about

\footnotetext{
${ }^{58}$ El Tiempo, 7/14/1997, Arauca, en medio de la guerra; retrieved from CINEP's newpaper archives in Bogotá, Colombia

${ }^{59}$ Peñate 1998: 25-26
} 
US\$632 million from ransom kidnappings of foreigners, the vast majority of whom were the employees of multinational corporations with operations in Colombia. ${ }^{60}$ As of 2004 , half of the world's kidnappings were taking place in Colombia. ${ }^{61}$ More than any other non-state armed actor in Colombia, kidnapping was central to the ELN's rent-seeking. ${ }^{62}$ By the late 1990s, the ELN had half the men in arms of that of the FARC and yet kidnapped about the same number of victims a year. While contrary to revolutionary ideals, the elenos justified kidnapping operations based on the premise that to not kidnap on a large scale would force them to burden the peasant population with the costs of the organization. ${ }^{63}$

The ELN's kidnapping activities were not evenly distributed throughout the insurgent group's area of influence, but rather concentrated in regions with oil production. For example, in 2001, the ELN abducted (and later released) 100 Occidental workers who were leaving the Caño Limón in Arauca. ${ }^{64}$ The workers were released upon collection of a retention tax. However, during this period the elenos increasingly resorted to assassinating their victims because the oil multinationals, now relying on the State for protection, would not negotiate payment. In April of 1997, the President of Occidental Petroleum in Colombia, Stephen Newton, reported that five contract employees had been killed by insurgents so far that year, and 14 employees were killed the year prior. ${ }^{65}$

\footnotetext{
${ }^{60}$ Richani 2005: 126

${ }^{61}$ Dunning and Wirpsa 2004: 88

62 The ELN carried out its first ransom kidnapping on February 5, 1970; Peñate 1998: 18

${ }^{63}$ Peñate 1998: 18

${ }^{64}$ Dunning and Wirpsa 2004: 88

${ }^{65}$ El Tiempo, April 21, 1997, La guerrilla nos acorrala: OXY retrieved in CINEP newspaper archives
} 
It was also during this period that the ELN extended their kidnapping activities beyond the oil companies, to include other local actors such as farmers, small miners, individual employees of firms contracted by mining companies, energy and public works companies, and even some politicians in charge of local expenditures. ${ }^{66}$ Many of the victims were not among the economic elite, but were from the middle and professional sectors. Finally, the de-forestation that occurred during the construction of oil installations resulted in the formation of a large prairie and a growing ranching industry. The ranchers also became targets of insurgent kidnappings. ${ }^{67}$

In sum, state protection of the oil industry destabilized the cooperative relationship that the elenos had established with oil multinationals and subcontractors in the period between 1983 and 1986. Initially, violence was limited to isolated situations, and rents were secured through direct taxes disguised as 'protection rents'. In exchange for the taxes, Domingo Laín refrained from attacking the oil infrastructure, kidnapping employees, and kept their peasant social base from demonstrations and strikes that would interfere with oil extraction. The cooperative relationship between Domingo Laín and Occidental and Ecopetrol would have remained stable had the national government not intervened, levying its own 'protection tax' on the oil multinationals and sending in military allies. The state's relationship with the oil industry impeded cooperative exchanges with the elenos, and the result was a more coercive and costly form of rentseeking.

\footnotetext{
${ }^{66}$ Peñate 1998: 18

${ }^{67}$ Author interview with community leader and former government official, January 20, 2012 in Arauquita, Arauca, Colombia
} 


\section{Predatory Insurgent-Civilian Relations}

Domingo Laín's coercive economic strategy resulted in predatory insurgentcivilian relations in Arauca defined as relations in which insurgents benefit at the expense of the local population. Domingo Laín's attacks on the oil infrastructure and related government corruption cost Arauca enormous losses in royalties and the department went bankrupt. This undermined local support for the elenos, even from the peasant sector. Indeed, the municipal governments were insolvent and Domingo Laín could not 'feed' their social base with jobs and programs. In addition to these direct costs, Domingo Laín's strategy created indirect costs including distorting the local economy, environmental population that undermined agricultural production, and the loss of life including hundreds of disappeared kidnap victims and targeted contract workers. The local opposition grew and forged alliances with FARC and paramilitaries to contest Domingo Laín's control. The resulting contestation brought unprecedented violence to Arauca.

Here, I provide evidence of predatory insurgent authority in Arauca. I define predatory authority as based on coercion or that 'enforces a group interest on an unwilling population. ${ }^{68}$ I capture ELN predatory authority with evidence of declining civilian support in Arauca. I use the following indicators. First, indicators of the high costs of the ELN's economic strategy in Arauca shows that insurgent authority was detrimental to the population's material security. Second, the demobilization of ELN militants in 1991 and the loss of key political allies such as unions indicates declining

\footnotetext{
${ }^{68}$ Wickham-Crowley 1987: 475
} 
civilian support consistent with predatory authority. Third, civilian cooperation with the ELN's armed rivals (paramilitaries, FARC, and state) is also consistent with predatory authority. Indeed, in 1998 there were massive popular demonstrations in ELN-controlled zones against the government's consideration of a demilitarized zone for negotiations with the ELN.

\section{The Cost of Domingo Laín's Economic Strategy}

Perhaps the clearest evidence of predatory authority in Arauca is the decline in the material security of the local population. Domingo Laín's coercive tactics resulted in the loss of millions of dollars in oil royalties for the local governments. The costs were significant, and spread across all sectors of the population. Beyond the loss of royalties and spilled oil, the local population absorbed the cost of repairing the pipeline, of polluted river water, of farmland that did not produce because of contamination, and of the human costs in deaths and injuries directly linked to attacks on the pipeline (and not including kidnappings and targeted assassinations).

These losses directly resulted from attacks on the oil infrastructure between 1986 and 2004. My argument is that the losses were avoidable had Domingo Laín maintained the protection racket and the cooperation of the oil companies in paying direct taxes. However, state policies that militarized the region and brought public goods such as schools and infrastructure previously supplied by the elenos, undermined cooperation between the insurgents and the oil companies, causing a shift in Domingo Laín's strategy toward greater coercion resulting in the losses listed in Table 4.3. 
Table 4.3, Costs of Attacks on Caño Limón-Coveñas Pipeline, 1986-1998 ${ }^{69}$

\begin{tabular}{|c|c|}
\hline Barrels of Oil Spilled & $1,634,920-1,785,000$ \\
\hline Loss of Government Royalties & $94,000-100,000$ million pesos \\
\hline Loss due to cost of Repairs & $58,000-70,000$ million pesos \\
\hline Water contamination (oil spills) & $\sim 1,800$ kilometers of river \\
\hline Land contamination (oil spills) & $\sim 1,500$ hectares of land \\
\hline Human Costs: Deaths and Injuries & $\sim 50$ deaths; $\sim 100$ injuries \\
\hline
\end{tabular}

Indeed, by 2001 the cost of repairs and lost oil as well as the complete shut-down of the pipeline operations for seven months reduced royalties from Caño Limón far below expectations. The National Royalty Fund suffered an estimated loss of \$32.6 million in royalties from Caño Limón in 2001 alone. But most critical in terms of insurgent-civilian relations, the department of Arauca lost an estimated $\$ 38.7$ million in expected royalties, and the municipalities lost out on an additional $\$ 10.2$ million. $^{70}$

For Arauca, the loss of oil royalties amounted to a social and economic crisis for the oil rich department. By 1998, the department was bankrupt with a public debt of

${ }^{69}$ El Tiempo, 7/1/1998, Arauca está al borde de la quiebra: gobernador; El Espectador, 7/5/1998, Lo que el petróleo se llevó; retrieved from CINEP newspaper archives in Bogotá, Colombia. The newspapers $E l$ Tiempo and El Espectador reported different numbers for barrels, royalties, and repair losses. El Tiempo's source was ECOPETROL. El Espectador did not name their source. I report both numbers here as a range. In all cases, El Tiempo gives the more conservative estimates. Also see J.F. Castro Caycedo (1997) Defensor del Pueblo, En Defensa del Pueblo, Acuso: Informe sobre impactos ambientales, económicos y sociales de la voladura de oleoductos en Colombia. Bogotá: Defensoría del Pueblo

${ }^{70}$ U.S. Dept. of State 2002 
$\$ 34,500$ million pesos. That year, the department's political leaders solicited the National Planning Department (DNP) and the National Education Ministry for assistance in meeting public expenditures. A major concern was meeting the costs of education in Arauca. Local resources did not cover the salaries of 1,600 teachers that year who went without pay, in addition to other expenditures that added up to $\$ 12,000$ million pesos annually. In addition to not paying teachers, three hundred local government functionaries in Arauca lost their jobs, and the departments three hospitals were preparing to shut down. ${ }^{71}$

Without a doubt, several factors contributed to the debt including government corruption, poor planning, and the fall in international oil prices. However, insurgent attacks on the pipelines played no small part in the impending economic crisis. ${ }^{72}$ This was by far the most critical factor, and a major contributor to poor planning and local corruption. ${ }^{73}$ Indeed, the attacks caused the pipeline to produce far below expectation and local budgets that were based on the projected production levels could not be supported. What is more, the insurgents were direct players in the corruption schemes that burdened local coffers.

The national government was slow to respond to the department's demands, and when the response came it was not as expected. In January 2003, Bogotá actually stripped the department of Arauca of control over its oil royalties in an effort to remedy the fiscal

\footnotetext{
${ }^{71}$ el Espectador, 7/4/1998, Se agrava crisis social y económica de Arauca; retrieved from CINEP newspaper archives in Bogotá, Colombia

${ }^{72}$ El Espectador, 7/5/1998, Lo que el petróleo se llevó; retrieved from CINEP newspaper archives in Bogotá, Colombia

${ }^{73}$ In the second half of 2001, the national prosecutor's office opened 20 investigations involving misuse of over 400 million pesos in Arauca; U.S. Dept. of State 2002
} 
crisis and take oil monies out of local coffers where it was being exploited by insurgent groups. ${ }^{74}$ In Bogotá it was argued that oil royalties should have created social and economic progress and the extension of state services, but chronic corruption impeded these efforts. And yet, the municipalities did invest in social infrastructure. Between 1987 and 2002, Arauca's per capita spending on social infrastructure was per capita US\$600, the highest in Colombia. ${ }^{75}$

Even so, Bogotá chastised the departmental government of Arauca for improperly monitoring the funds. In 2003, the national government passed a 'fiscal responsibility law' to hold local officials accountability for the misuse of royalties. ${ }^{76}$ In 2002 , Colombian President Alvaro Uribe criticized the department for its inefficiencies and told U.S. officials that Colombia was committed to improving social and economic development in strategic regions with oil and other valuable natural resources, even if it means taking direct control of oil royalties in departments like Arauca. ${ }^{77}$ Hence, the department and municipalities not only endured economic losses but also political losses as a direct result of Domingo Laín's coercive rent-seeking.

\section{Cooperation with Rivals}

Predatory insurgent-civilian relations are also evidenced by the formation of a popular opposition to the elenos and territorial contestation between Domingo Laín and

\footnotetext{
${ }^{74}$ U.S. GAO Report GAO-05-917

${ }^{75}$ U.S. Dept. of State 2002

76 See Steven B. Webb, Fiscal Responsibility Laws for Subnational Discipline, The Latin American Experience, World Bank Policy Research Paper 3309, May 2004

${ }^{77}$ U.S. Dept. of State 2002
} 
new armed actors. ${ }^{78}$ Beginning in 1997 , the ELN suffered some important setbacks as paramilitaries and the FARC constructed territorial footholds by forging alliances with those sectors that opposed the ELN, or were left out of the elenos patron-client networks In 1997 alone, the elenos lost 477 combatants and several hundred more due to capture by state and paramilitary forces. The elenos lost strategic areas such as San Vicente de Chucurí (Santander), parts of northeast Antioqueño and of south Bolívar, and the Serranía de San Lucas, and in the oil capital of Barrancabermeja. ${ }^{79}$ Finally, in Arauca, the ELN lost territorial control to the FARC and ultimately to paramilitary forces. ${ }^{80}$

Not surprisingly, the oil companies were the direct targets of Domingo Laín's attacks and therefore the first to seek allies from among the ELN's armed adversaries to drive the insurgents out. At first, the companies collaborated with legal national and local security forces to protect their oil infrastructure. ${ }^{81}$ However, after 1997 the oil companies began mixing with more dangerous allies, the right-wing paramilitary organization United Self-Defense Forces of Colombia (AUC). The role of multinational oil companies in allegedly funding paramilitary activities is controversial because of the paramilitaries' horrendous human rights record. In Arauca, paramilitaries targeted not just ELN combatants but of their supposed civilian supporters and collaborators.

\footnotetext{
${ }^{78}$ Oil also increased contestation by providing rents for military build-up to opposing sides: the state and insurgents. Both armed actors expanded their military capacity with oil rents and the ratio of insurgent and national military war fatalities reflects this military balance. In 1986, the ratio was 1:1.52 in favor of the state, and in 1999 that ratio was 1:1.59 in favor of the state; Richani 2005

${ }^{79}$ Richani 2002: 87

${ }^{80}$ Sánchez and del Mar Palau 2006: 10

${ }^{81}$ Guáqueta 2003: 85
} 
The paramilitary movement in Arauca was not homegrown, but an external force that arrived from the Caribbean coast. ${ }^{82}$ In 1997 the infamous paramilitary leader Carlos Castaño Gil created the United Self-Defense Forces of Colombia (AUC), a national umbrella organization that united several regional paramilitary movements. In 1998, the AUC deployed a force of 800 combatants to Arauca. The AUC Bloque Vencedores de Arauca had financial backing from the oil multinationals. ${ }^{83}$ At one point, Occidental transferred US\$2 million to Castaño for pipeline protection. Castaño later reported that the AUC 'taxed the multinationals like the guerillas did'. ${ }^{84}$ The AUC conquered significant territory through which the oil pipeline passed.

Arauca was among the most difficult zones for the paramilitaries to conquer owing to the strong patrimonial links between the peasant sector and the elenos. Arauca was "... donde la guerrilla era amo y señor," 85 The AUC's success is attributed to their powerful alliance with oil multinationals, and also to their brutality. The national military was constrained by international human rights norms. However, the paramilitaries were able to fight a dirty war in Colombia.

In Arauca, they targeted the insurgents' civilian support base, and most especially members of the peasant organization National Association of Rural Peasants (Asociación Nacional de Usuarios Campesinos; ANUC). In Sarare, most peasants were members or supporters of ANUC. Domingo Laín's failure to protect the peasants from paramilitary

\footnotetext{
${ }^{82}$ Locals report that the paramilitaries are identifiable by their distinct costeño (Caribbean) accents.

${ }^{83}$ Richani 2002; Richani 2005: 122

${ }^{84}$ Dunning and Wirpsa 2004: 88-89

85 Even Colombia's most powerful paramilitary bosses did not want the Arauca misión including commanders like Ramón Isaza from Antoquia, Botalón from Puerto Boyacá, and even el Señor Don Berna of Medellín. Eventually, Pablo Mejía (Víctor Mejía Munera) took the mission; Ávila Martínez 2011: 24
} 
violence further contributed to declining support from the peasant sector. Finally, the paramilitaries also targeted local political leader with suspected links to the ELN and also the $10^{\text {th }}$ front of the FARC, which had a presence in the region. ${ }^{86}$

To further undermine the elenos control over oil royalties, the paramilitaries launched a violent campaign in 2001 to run the insurgents out of the city of Barrancabermeja, home to Colombia's largest oil refinery. There, the AUC targeted and annihilated the leadership of the Oil Workers Union (USO). Since the ELN's founding in 1964, the USO was part of the insurgents' urban coalition. Between 1998 and 2004, eighty five USO members were assassinated and two more disappeared. ${ }^{87}$

After conquering the ELN's historic stronghold in oil-rich regions of the Magdalena Medio and eastern plains, the paramilitaries began to exploit the oil industry. A large part of this was extorting oil multinationals and capturing construction contracts in oil zones as did the ELN had done before. However, the paramilitaries were also able to developed a 'cottage industry' around stealing gasoline by drilling holes in the pipelines that transported fuel, costing ECOPETROL an additional US\$5 million a month between 1998 and 2005. The paramilitaries reportedly sold the stolen fuel to service stations or along major departmental thoroughfares at reduced prices. ${ }^{88}$

Importantly, the paramilitaries were not the only challenge to Domingo Laín's territorial control in Arauca. Other sectors of the population left out of the elenos patronclient networks suffered the costs of Domingo Laín predation and forged an alliance with

\footnotetext{
${ }^{86}$ In 1994 the Colombian government's legalization of armed civilian self-defenses groups legitimized the paramilitary movement; Pearce 2005:49

${ }^{87}$ Dunning and Wirpsa 2004: 88

88 ibid: 90
} 
the FARC. Among them were the region's small sector of coca-growing peasants. The FARC's $10^{\text {th }}$ front Guadalupe Salcedo entered the department of Arauca in 1982 and began mobilizing the coca-growing peasants that were left out of the ELN's clientelistic bargains. The FARC protected the coca growers while collecting a per kilogram tax on coca sales paid by the buyer. ${ }^{89}$ "The coca bonanza allowed the advance of the FARC [in Arauca], and they survived collecting taxes, ${ }^{90}$ By the late 1980s the FARC's presence in Arauca numbered just 200 fighters, but by the mid-1990s the FARC, an outside force in the region, had increased their presence to about 1,000 fighters, at least 500 more than the ELN. $^{91}$

The FARC entered Arauca as part of a national strategy to increase their territorial presence across Colombia. In 1984 during the peace talks with President Belisario Betancur (1982-1986), the FARC created their own political party, the Unión Patriótica (Patriotic Union; UP). The UP ended up playing a central role in the politics of Arauca. ${ }^{92}$ Indeed, the FARC first won over the territory politically, by supporting UP candidates who delivered goods to peasant communities. In exchange, those communities supported the FARC and the UP. By 1997, the FARC maintained two fronts, the $10^{\text {th }}$ front Guadalupe Salcedo and the $45^{\text {th }}$ front, in Arauca with about 500 armed combatants or roughly 200 more combatants than the ELN. ${ }^{93}$

\footnotetext{
${ }^{89}$ Author interview with former municipal official on January 20, 2012 in Arauquita, Arauca, Colombia 90 ibid

${ }^{91}$ Richani 2005: 122

92 Pearce 2005: 43

93 El Tiempo, 7/14/1997, Arauca, en medio de la guerra; retrieved from CINEP newspaper archives in Bogotá, Colombia; Author interview with community leader and former government official, January 20 ,
} 
According to local testimonies, the internal war that ensued between the FARC and the ELN in Arauca between 1997 and 2004 claimed more lives than all previous fighting between the elenos and the military and even the activities of right-wing paramilitaries. $^{94}$ They recall this period as one of extreme and unprecedented violence in Arauca, in which the peasant population became divided between FARC camps and ELN camps wherein each group targeted the other's social base.

By most accounts, the ELN was portrayed as most culpable for targeting civilians. The result of violence, which principally took place in the municipalities Tame, Fortun, Arauquita y Saravena, was massive internal displacement, economic stagnation, and a concentration of land as peasant families under-sold their properties and fled. ${ }^{95}$ As of 2012, the municipal center of Arauquita was surrounded by hundreds of make-shift lots with homes constructed from plastic and paper with dirt floors. ${ }^{96}$ These are the displaced communities driven out of rural zones by the violence between the FARC and Domingo Laín. They occupy public lands outside of the town center, and pressure the local government to title the land to them because they have no intention of returning to their place of origin. ${ }^{97}$ A victim of displacement in Arauquita, Arauca explains:

...Here practically all the displacement was because of the conflict between the two groups, the FARC and the ELN, or because, well, if you aren't with

2012, Arauquita, Arauca, Colombia; Guadalupe Salcedo was a famous leader of the Liberal Guerillas during the era of La Violencia (1948-1963). Salcedo was from Fortun, Arauca.

${ }^{94}$ Author interview with community leader in Arauquita, Arauca, January 20, 2012

95 Author interview with former municipal official in Arauquita, Arauca, January 20, 2012

${ }^{96}$ During one interview with a displaced civilian, I was told that in that neighborhood alone (one of dozens) there were 83 lots. Each lot was occupied by a family as large as 13 individuals; Author interview, Arauquita, Arauca, January 21, 2012

${ }^{97}$ Author interview with member of community action board in Arauquita, Arauca, January 21, 2012 
one side you are with the other. So, those that didn't want to be on either side had to leave...the guerilla enters and the people, what they do is run... ${ }^{98}$

...the confrontation between the ELN and the FARC killed a lot of people because there is a false concession for the ELN, or the elenos as they say. They say that if you are not with them you are against them. The same for the FARC, those that aren't with the FARC are against them. Many innocent people died that weren't for one or the other. Many leaders. Many social and labor leaders. And those that didn't die, many left, many fled to Venezuela... ${ }^{99}$

In 2004, the two insurgent groups signed a truce and the violence declined significantly. However, during my visit in 2012 the local community remained skeptical that the truce would not be broken. The FARC's foothold in Arauca demonstrates the ELN"s weak hold on territory and the strength of the popular opposition to the elenos. Domingo Laín's economic strategy marginalized large sectors of the peasant population, making them available to the FARC. What is more, the FARC's economic strategy supports my argument that the politics of resources explains a great deal in the way of insurgent rent-seeking and relations with populations. The FARC's organizational structure was much more disciplined and centralized than the ELN. And yet, the FARC eventually exploited the oil sector in Arauca using tactics remarkably similar to Domingo Laín's tactics a decade prior. By 1998 the FARC was claiming responsibility for numerous attacks on the pipeline, including seven threats that took places between July 19 and 21, 1998. In several public declarations the FARC announced that the petroleum industry represented a legitimate military-target. ${ }^{100}$

\footnotetext{
${ }^{98}$ Author interview with member of community action board in Arauquita, Arauca, January 21, 2012 ${ }^{99}$ Author interview with former municipal official in Araquita, Arauca, Colombia, January 20, 2012 ${ }^{100}$ El Tiempo, 7/1/1998, Arauca está al borde de la quiebra: gobernador; retrieved from CINEP newspaper archives in Bogotá, Colombia
} 


\section{Declining Peasant Support in Sarare}

Third, the decline in peasant support for the ELN is evidence of predatoryinsurgent relations. In 1998, greatly weakened by paramilitary incursions, the ELN sought a National Convention with the government to negotiate the terms of the insurgents' demobilization. ${ }^{101}$ As part of the negotiation, the elenos requested a demilitarized zone centered on the gold mining region of Serranía San Lucas in Bolívar. As proposed by the ELN, the Serranía zone would be similar to the demilitarized zone created for the FARC in Caquetá. Bogotá was willing to grant the request, but massive popular protests in ELN-controlled territories convinced the government to suspend plans. While the popular protests were perhaps organized and supported by paramilitary forces, there is also evidence that the peasant sector participated voluntarily.

The loss of peasant support powerfully demonstrates that the even the ELN's social allies felt the weight of the elenos economic strategy. It also matters that Domingo Laín won the support of the peasants by influencing the use of royalties and public expenditures in favor of the peasant sector. Hence, peasant support for Domingo Laín was contingent upon the peasants benefiting with private goods, and once the insurgents could no longer deliver these goods peasant support diminished.

From the beginning, Domingo Laín claimed to represent the interests of the peasant communities in Sarare by 'justly' redistributing oil royalties and forcing the oil multinationals and the state finance social programs in the area and provide jobs. However, the activities of the ELN significantly reduced oil revenues earmarked for

${ }^{101}$ Rodríguez Pizarro 2005: 138 
social infrastructure to development to benefit the people of Arauca. ${ }^{102}$ What is more, the attacks led to oil spills that polluted water, left farmland unfertile and led to additional explosions and 'collateral damage'.

Indeed, the peasant communities were not secure from the negative externalities of attacks on the oil pipelines. A major event that contributed to declining peasant support for the elenos was the tragedy of Machuca in 1998. The ELN attacked a pipeline in the early morning, causing a petroleum leak that descended down a river toward a peasant community situated on a river bank. The petroleum mixed with candela that had been disposed of in the river after being used for cooking. The result was a deadly explosion that killed 73 civilians, all of them were peasants and 36 of them were children. $^{103}$

Moreover, the militarization of the region and ensuing contestation resulted in more direct targeting of civilians suspected of being military collaborators. In a notorious example of insurgent violence in Arauca, Domingo Laín targeted and assassinated more than eight girls ranging in age from 14 to 23 between 1994 and 1995 . The girls were suspected of being 'friends of the police and paramilitary' based on rumors that the girls had romantic relationships with soldiers or police. The girls were assassinated publically getting off of buses or walking in the town center. The ELN openly accepted responsibilities for the killings. ${ }^{104}$

\footnotetext{
102 Holmes and Gutiérrez de Piñeres 2012: 102

103 Pearce 2005: 26

${ }^{104}$ El Tiempo, May 5, 1996, Radiografía del Domingo Laín, retrieved in the CINEP newspaper archives
} 
Even beyond the peasant sector and the department of Arauca, Domingo Laín's activities contributed to a declining support for the ELN at the national level. In the cities, the ELN's kidnapping activities were abhorred by urbanites. The Oil Worker's Trade Union (USO), a longtime political ally of the ELN in the Magdalena Valley region, publically denounced the ELN's activities citing the cost to the industry which in the long term translated into a loss of resources and therefore revenues for the communities and for Colombia. ${ }^{105}$

Indeed, almost all legal organizations on the left rejected the ELN's strategy of attacking the oil pipelines and extorting oil companies. This included a large faction of the Catholic community, once a powerful supporter of the elenos. In the department of Arauca, the ELN's fear of civilian collaboration with the military and paramilitary led to the assassination of prominent local Priests, including the high profile assassination of the Obispo of Arauca Father Jesús Emilio Jaramillo in 1989. ${ }^{106}$

In 1999, Domingo Laín announced that they would not permit the construction of new churches, nor admit religious persons or unknown pastors in Sarare because of suspicions that the new sects were financed by multinationals and foreign movements that are attempting to launch a counter-insurgency in Arauca. ${ }^{107}$ However, at that point the insurgents' predacious policies and violence had already caused the demobilization of most of the ELN's political wing in 1991. After demobilizing, the former ELN militants

\footnotetext{
105 Pearce 1995: 19, footnote

${ }^{106}$ El Tiempo, 10/10/1999, Eln amenaza los cultos evangélicos en Saravena; retrieved from the CINEP newspaper archives.

107 ibid
} 
formed the Corriente de Renovacion Socialista (CRS), which is today a legitimate political party in Colombia. ${ }^{108}$

In sum, the ELN's coercive tactics against oil companies generated local support based on the transfer of private goods rather than legitimate authority. Over time, the costs of the ELN's strategy and their inability to protect their social base from a powerful and violent opposition resulted in lost credibility particularly after the Machuca massacre. This only increased local support for the FARC and right-wing paramilitaries that were attempting to usurp control in the region. ${ }^{109}$

By the mid-1990s the FARC had appropriated the support of most of the peasant sector in Sarare. In Sarare, the FARC used many of the same tactics that the ELN employed in the early 1980s such as threats of violence to force entities such as INCORA to deliver public resources paid for with oil royalties to the neighborhoods. The FARC's support for the Patriotic Union (UP), a leftist party that emerged in the 1980s as result of negotiations between the insurgents and President Belisario Betancur (1982-1986) resulted in UP victories for Congress and local Council in three municipalities of Sarare. The Conservative party practically disappeared from the region and the Liberals, allied with Domingo Laín, lost considerable control. Some traditional politicians actually joined the UP, while others were killed or fled the zone. ${ }^{110}$

\footnotetext{
${ }^{108}$ Ruiz 2001: 188

${ }^{109}$ Pearce 2005: 37

${ }^{110}$ Peñate 1998: 21
} 


\section{Conclusion}

In a now classic study on oil and conflict in Colombia, Jenny Pearce argues that it was not inevitable that petroleum would play the role that it did in generating violence. She says that it's not just the presence of a lucrative resource that matters, but the politics that surrounds it. ${ }^{111}$ My research supports Pearce's conclusion. The state's militarization of Arauca was a central factor in the breakdown of order and ensuing violence. One could argue that the State was successful since the ELN no longer has a strong presence in Arauca. However, local populations paid a high price for that success. Moreover, the state's policy of fiscal decentralization was intended to increase the use of royalties for local development and public goods, but more centralized control was needed given weak local political institutions. In both Arauca and Casanare the oil bonanza failed to generate self-sustaining economic development. ${ }^{112}$

Hence, Arauca offers some important lessons for Colombia and for addressing the confluence of oil and conflict in other settings. As coca-cultivation declines in Colombia, oil exploration and extraction is increasing and exacerbating the armed conflict in other Colombian regions. ${ }^{113}$ The oil fields in Arauca and Casanare dried up in the early 2000s, and as a result the Colombian government has opened up even more to attract foreign investment in exploration and exploitation of new reserves. Based on new discoveries,

\footnotetext{
${ }^{111}$ Pearce 1995: 10

112 Pearce 2007: 225

${ }^{113}$ The United Nations Office on Drugs and Crime (UNODC) notes a significant and consistent decline in coca cultivation in Colombia since 2007. In some U.S. and Colombian policy circles the outcome is cited as evidence that aerial fumigation works as a counter-narcotics policy. Unfortunately, the decline in Colombia has coincided with an equal increase in cultivation in Peru.

http://www.unodc.org/unodc/en/press/releases/2009/june/unodc-reports-steep-decline-in-cocaineproduction-in-colombia.html
} 
most petroleum extraction today takes place in the department of Meta and Caquetá, where the presence of Canadian multinationals exacerbates the ongoing armed conflict.

Beyond oil, the Arauca experience is also applicable to regions with other types of lucrative and licit war commodities that demonstrate a remarkably similar effect on state policies, insurgent strategies, and conflict dynamics. For example, about half of coal excavation in Colombia takes place in the Cerrejón Norte region where coal excavation is a joint venture between the government and the U.S.-based Exxon Corporation. The Colombian military provides constant security for the mining sector, Colombia's third most important source of foreign export income. Insurgents target the trains that transport the coal with explosions, sometimes extorting Exxon in order to avoid the attacks. ${ }^{114}$

Today, the National Liberation Army exists as an insurgent organization, albeit extremely weak and on the verge of defeat. The ELN suffered tremendous losses in social support, territorial control, and military capacity during the period between 1991 and 2002. The defeat of their strongest front, Domingo Laín, in the department of Arauca was a major setback. By 2004, the ELN expressed willingness to negotiate their demobilization with the national government. In 2011, the insurgents began taking serious steps to initiate that conversation with Bogotá. The ELN persists in some regions through alliances stronger armed actors. In regions with illicit cultivation, the ELN allied with the FARC as the dominate actor. However, in the (former) oil producing regions of Arauca and Casanare the ELN and the FARC are enemies. In fact, in Arauca the ELN is

\footnotetext{
${ }^{114}$ Richani 2005: 124
} 
allied with the national military against the FARC. In other regions, such as Nariño, the ELN has an alliance with neo-paramilitary groups.

Meanwhile, the FARC persists as the stronger insurgency at the national and local level. Despite persistent attempts, paramilitary forces failed to gain significant ground in the Western Amazonian departments where coca cultivation concentrated in the 1990s. Caquetá and Guaviare remained FARC strongholds, and the paramilitaries were literally driven out of Putumayo by local peasants. The paramilitaries did form strongholds in Meta, a coca-growing department with significant oil extraction, and in some parts of Putumayo. Paradoxically, the FARC cultivated much stronger ties with local communities despite a longer and more profound relationship to the drug trade. The following chapters demonstrate how coca cultivation was the basis for a cooperative relationship between the FARC and the peasant populations. 
Part II

Coca and Legitimate Authority: The FARC in Caquetá 


\section{Chapter Five \\ Coca: State Response to an Illicit Commodity}

"In the evolution of internal war, it may be that policy failure, of will and of omission, account for missed opportunity as much as does the presence of economic resources."

"Aerial spraying [of illicit crops] is said to belong to the realm of national security. Under this guise, it is exempt from any demands to curb the indiscriminate use of chemical agents. In effect, its permissiveness in implementing this policy not only detracts from the state's own legitimacy, it turns the Colombian State into one of the main generators of environmental insecurity. ${ }^{2}$

Illicit drug cultivation correlates with the development of strong insurgent "protostates' in practically every instance in which illicit production and conflict collide, across countries as far-flung as Colombia, Peru, Afghanistan, and Burma. ${ }^{3}$ In Colombia FARC guerillas exercised legitimate authority vis-à-vis local populations precisely in those regions where one finds the highest concentration of coca farms. What explains the link between illicit commodity production and legitimate authority? Coca is a raw material export. It is not intrinsically different from any other war commodity, except that coca is illicit and this merits a distinct response from the state. In the context of internal war, states attempt to repress illicit war commodities and exclude the 'criminal' communities that participate in their production. Insurgents can capitalize on state exclusion by incorporating illicit producers with public goods as a method for accessing illicit rents. The result is legitimate authority or power by consent.

This chapter links the presence of illicit coca to a national government policy of repression in the department of Caquetá, Colombia. The chapter is divided into three

\footnotetext{
${ }^{1}$ Pearce 2007:226

${ }^{2}$ Vargas 2002: 33

${ }^{3}$ Felbab-Brown 2009
} 
parts. First, I describe the illicit economy in Colombia and the local conflicts it generated in the department of Caquetá during the first coca bonanza that began in 1978. Second, I show how a national interest formed around repressing the illicit economy and politically abandoning the region as a counterinsurgency tactic. Last, I link the national interest to the state's political neglect of Caquetá and the repressive tactics used to ostracize the peasant population of that region. I draw evidence from published historiographies of Caquetá, unpublished regional ethnographies and testimonies, and interviews conducted in Bogotá, Colombia in 2011 with academic experts, community and church leaders, and human rights organizations.

\section{Antecedents: Coca and Conflict in Caquetá}

Coca is not a traditional Colombian crop. In fact, most illicit drugs that passed through Colombia during the twentieth century were processed from coca leaf grown in Peru and Bolivia. ${ }^{4}$ In these two countries, indigenous communities have cultivated coca for centuries. Nonetheless, during the 1980s and 1990s Colombia became the world's largest coca leaf producer. In Colombia most coca is grown illegally for processing cocaine. In the beginning, coca production had only a small impact on Colombia's core regions. Even while Colombian cities were consumed by drug cartel violence in the 1990s, these populations were barely affected by illicit cultivation. However, Colombia's vast and marginalized frontier regions were transformed by coca production. Indeed,

\footnotetext{
${ }^{4}$ Gootenberg 2008: 291-324; Thoumi 1995: 79
} 
entire peasant communities of the Western Amazon and llanos frontier became directly involved and dependent on the illicit coca economy.

One of the Colombian communities most affected by the coca bonanza was the lower Caguán region of the department of Caquetá. In El Caguán, coca cultivation increased the incomes of thousands of poor subsistence farmers. Coca broke a treacherous cycle of poverty and debt that characterized the colonization of a region isolated from regional markets. However, the cost of prosperity was crime and violence. For Caquetá, the coca bonanza brought extreme disorder to a formerly tranquil peasant community. Within this context, local community organizations in Caquetá asked for national government support in order to eradicate coca through economic development. However, the government neglected the region's development problems and instead repressed coca producers with forced eradication policies. In order to explain the state's repressive reaction to coca cultivation in Caquetá, I start with a description of the illicit drug trade in Colombia, including the actors involved and the conflicts that emerged.

\section{Coca Cultivation in Colombia}

Despite Colombia's reputation as a source of cocaine, very little drug cultivation actually occurred in Colombia until the 1980s. Early on, the Upper Huallaga Valley of Peru, and to a lesser extent the Chapare region of Bolivia, were the main sources of illicit coca for processing cocaine..$^{5}$ Colombia's traditional role in the Andean drug trade is in coca processing and trafficking. In the 1970s, the Peruvian market was monopolized by a dozen or so Colombian drug traffickers. The traffickers purchased raw coca or coca paste

\footnotetext{
${ }^{5}$ Gootenberg 2008
} 
(the base for cocaine) from Peruvian cultivators and then transported their merchandise across the border, usually by plane. In Colombia, the traffickers set up hidden laboratories where the coca was refined into cocaine and exported to North American and European markets ${ }^{6}$.

However, beginning in the late 1970s, coca cultivation shifted across the border and into Colombia. The steady increase in coca cultivation in Colombia between 1978 and 2004 was due to three factors. First, in 1978, Colombian President Julio César Turbay Ayala, under strong pressure from the United States, implemented a marijuana eradication campaign. During the 1970s, a thriving marijuana trade had developed in the Sierra Nevada de Santa Marta region on the Caribbean coast of Colombia. As a result of Ayala's crackdown, marijuana smugglers turned to the more lucrative cocaine trade. ${ }^{7}$ The decline of the marijuana trade and the subsequent shift to cocaine was the main factor leading to the first Colombian coca bonanza in Caquetá as well as in neighboring Guaviare and Meta between 1978 and 1982. Drug smugglers from Medellín first introduced coca seeds to peasant settlers in the Amazonian and llanos regions far beyond the reach of the state. ${ }^{8}$ Caquetá was one of the regions where coca seed was introduced.

However, while the decline of the marijuana trade contributed to the first coca cultivations, other factors caused a steady increase in coca cultivation in Colombia up to 2007. The second factor contributing to cultivation in Colombia was the successful interdiction efforts in Peru. In the early 1980s the United States war on drugs began to

\footnotetext{
${ }^{6}$ McClintock 1988: 128-129

${ }^{7}$ Felbab-Brown 2009: 71

${ }^{8}$ Thoumi 1995: 125-128
} 
favor supply-side antinarcotics policies in the Andean region, targeting the Peruvian coca market. As a result, the U.S. and Peru stepped up efforts to interdict the 'air bridge' between Peru and Colombia by forcing down or shooting down planes suspected of carrying coca base. ${ }^{9}$ The policy was successful if measured by the decline in coca production in the Upper Huallaga Valley of Peru. However, the interdiction efforts and the U.S. 'War on Drugs' more broadly did not curtail the flow of illicit drugs into the U.S. market. Rather, interdiction in Peru merely shifted some of the illicit production to Colombia.

Decentralization of the Colombian illicit market was the third factor that caused the acceleration of coca production in Colombia during the 1990s. In 1989 liberal politician Luis Carlos Galán was assassinated by the Medellín drug cartel, prompting the state to declare war on drug traffickers. In response to the government crackdown, the Medellín and Cali drug cartels began to break their operations down into smaller, more networked cartelitos (baby cartels). ${ }^{10}$ The international networks that facilitated the purchase of coca from Peru broke down along with the two-cartel system. ${ }^{11}$ Hence, the leaders of the cartelitos bolstered cultivation in regions such as El Caguán, Caquetá, where the Medellín Cartel had introduced coca seed a decade prior.

\footnotetext{
${ }^{9}$ A mere 13 per cent of planes transporting illicit drugs between Peru and Colombia were interdicted. Nonetheless the policy deterred traffickers as indicated by a sharp reduction in aerial transport of illicit coca paste to less than 10 per cent of pre-1995 levels. The result was a severe contraction of the Peruvian illicit coca business. Within four months, Peruvian producers suffered a 75 per cent decrease in coca prices followed by a 66 per cent drop in cultivation; see Anthony et al. 2000: III-7.

${ }^{10}$ During the 1980s and early 1990s, the Colombian illicit export market was monopolized by the Medellín Cartel and the Cali Cartel.

${ }^{11}$ Thoumi 1995: 98-99
} 
In the Western Amazonian and llanos regions cocaine traffickers found many impecunious and indebted peasant settlers or colonos eager to grown illicit crops because of the lack of viable legal economic alternatives. The traffickers provided the seeds for the first production cycle, and sent intermediaries to purchase the product, thereby eliminating economic risk and transportation costs for the peasants. ${ }^{12}$ Indeed, Colombia has the perfect conditions for a flourishing drug trade; well-established drug trafficking syndicates and a vast 'stateless' frontier inhabited by economically marginalized peasants. As a result of these conditions, illicit cultivation increased in Colombia by 500 percent between 1978 and 1998 to an estimated 169,800 hectares. $^{13}$

Cocaine exports from Colombia to the United States increased from an estimated six tons in 1973 to five hundred tons in 1999, which made Colombia the world's top producer and exporter of illicit coca and its psychoactive derivative, cocaine. ${ }^{14}$ Since 2007, coca production has declined in Colombia. The decrease in coca cultivation in Colombia has coincided with a revival of the coca market in Peru. However, as of 2008, Colombia was still producing an estimated 430 metric tons of cocaine using raw coca grown in Colombia. ${ }^{15}$

\footnotetext{
${ }^{12}$ McClintock 1988: 131; Perl 1992

${ }^{13}$ Felbab-Brown 2009: 72

${ }^{14}$ Thoumi 1995: 88; Richani 2002: 96, footnote

${ }^{15}$ Mejía and Rico 2011: 16
} 
Graph 5.1 Coca Cultivation (ha.) in the Andes, 1994-2010 ${ }^{16}$

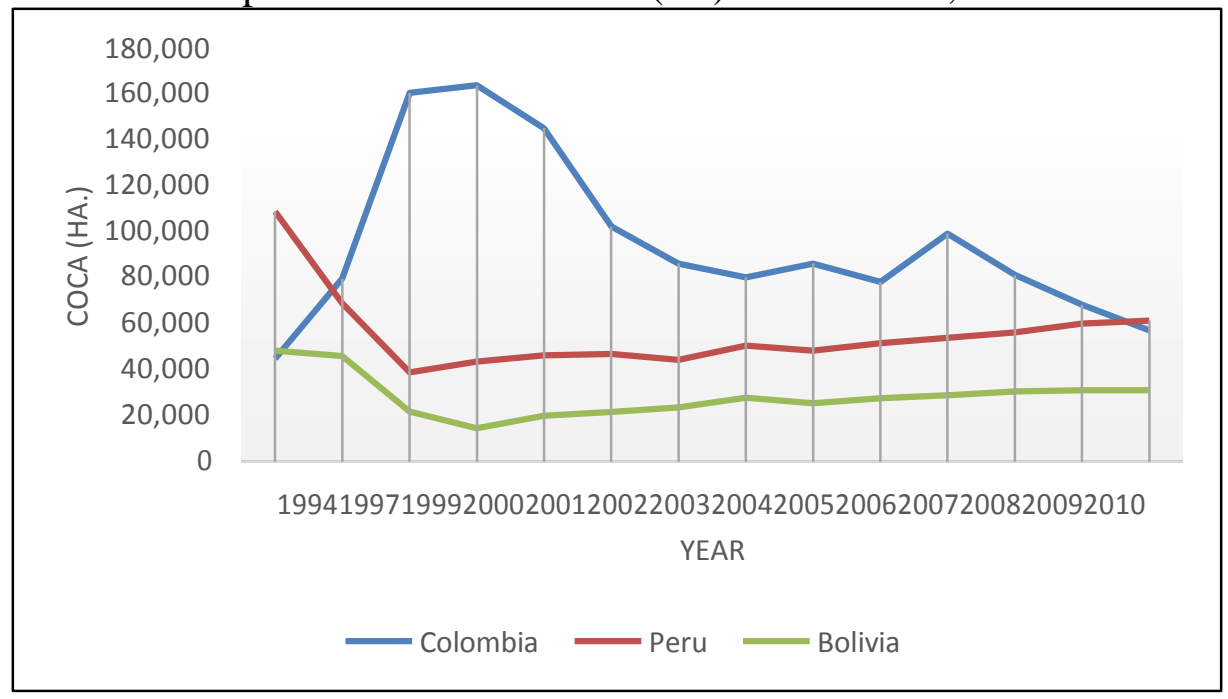

\section{The Coca Commodity Chain: Actors and Interests}

State repression of coca was a response to the enormous threat posed by illicit production within Colombia's borders. In Colombia, illicit drug production was the first and most important link in an elaborate shadow economy that benefited criminals and insurgents at the expense of the state. Coca profits were in the hands of private actors that attacked, undermined, and corrupted state institutions. While drug traffickers had long operated in Colombia, coca production greatly increased the threat by incorporating new actors including insurgent groups into the shadow economy. Indeed, drug trafficking involved only a handful of individuals since it was carried out by small networks of smugglers. However, illicit drug production was a labor-intensive, multi-step process that incorporated entire sectors of Colombia's rural population. Hence, when coca cultivation

\footnotetext{
${ }^{16}$ UNODC Coca Cultivation Survey, Andean Region 2010
} 
expanded across the Colombian frontier, thousands of Colombians became direct participants in an illicit shadow economy that the state could neither tax nor regulate.

Indeed, in Colombia the growth of the illicit economy had an immense social impact, particularly in rural areas. A wide range of social sectors became directly involved, including peasants and small farmers, chemists, chemical suppliers, smugglers, merchants, pilots, bodyguards, front men or testaferros, narcotics traffickers, and money launderers. In addition, a much more extensive group indirectly participated, functioning as a social support network. The illicit market required the participation or at least complicity of political elites, police and members of the armed forces, public employees, and lawyers. ${ }^{17}$ Finally, beyond the production stage, the illicit economy employed tax advisers, financial advisors, and bankers to help manage the elaborate money-laundering system that was needed to hide enormous illicit profits. ${ }^{18}$

Among these actors, illicit producers received the smallest share of the profits generated by illicit cultivation. Coca production and trafficking are high risk economic activities. For this reason, considerable resources went to pay off the various actors in the social support network. The result was high value added to each kilogram of cocacocaine moving up the commodity chain and a concentration of profits at the top. Table 5.2 demonstrates the high percentage of total profits captured by narcotics traffickers. Hence, a relatively small and powerful group of narcotics traffickers benefited at the expense of an extensive but powerless group of peasant illicit cultivators. Narcotics traffickers monopolized local markets, keeping the price of raw coca low. However, the

\footnotetext{
17 Thoumi 1995: 96-97

${ }^{18}$ Krauthausen and Sarmiento 1991
} 
FARC later intervened on behalf of producers to protect prices, even displacing the intermediaries who worked for narcotics traffickers, becoming the sole purchaser of coca in some communities.

Table 5.2 Distribution of Value of Production of Cocaine in Colombia, $2008^{19}$

\begin{tabular}{|c|c|c|}
\hline Production Phase & Value & $\begin{array}{c}\text { Principal Actors } \\
\text { Involved }\end{array}$ \\
\hline Production of coca leaf & $\$ 1.2$ billion & $\begin{array}{c}\text { Peasants, Small } \\
\text { Farmers }\end{array}$ \\
\hline $\begin{array}{c}\text { Production of coca base } \\
\text { Production of cocaine } \\
\text { hydrochloride } \\
\text { (crystalizing) }\end{array}$ & $\$ 0.8$ billion & $\begin{array}{c}\text { Peasants, Small } \\
\text { Farmers/Merchants }\end{array}$ \\
\hline $\begin{array}{c}\text { Wholesale trafficking of } \\
\text { cocaine to coast and } \\
\text { frontiers (domestic) }\end{array}$ & $\begin{array}{c}\text { Chemists, labs } \\
\text { controlled by } \\
\text { Narcotics } \\
\text { Traffickers }\end{array}$ \\
\hline $\begin{array}{c}\text { Total Value } \\
\text { Thion billion }\end{array}$ & $\begin{array}{c}\text { Narcotics } \\
\text { Traffickers }\end{array}$ \\
\hline
\end{tabular}

The first two phases of illicit production were peasant economies. The production of coca and coca paste was mostly carried out by peasants and small farmers in the most marginal regions of Colombia, including the departments of Guaviare, Caquetá, Meta, Nariño and Putumayo south of the capital city of Bogotá, and North Santander, Arauca

\footnotetext{
${ }^{19}$ Mejía and Rico 2011: 16

${ }^{20}$ This does not include the supply phases: international trafficking, retail distribution in consumer countries and money laundering.
} 
and Bolívar in the eastern plains and Caribbean regions. Among these departments one finds 47 per cent of the total coca cultivation in Colombia concentrated in just 10 municipalities. ${ }^{21}$ FARC guerillas were active in all 10 municipalities during the height of illicit cultivation in the 1980s and 1990s.

Most illicit cultivators were permanent frontier settlers who grew foodstuffs and devoted about a quarter of their land to cultivating illicit drugs for profit. Between 1978 and 2007, the average plot was only 1 hectare and most labor was family labor. ${ }^{22}$ In addition to settled peasants, recent migrants - some from urban areas - also engaged in coca farming, but devoted more of their time and resources to producing coca paste. ${ }^{23}$ In 2005, an estimated 68,600 Colombian households were involved in coca cultivation. ${ }^{24}$ By 2008, despite the decline in the area of illicit coca cultivation, the number of households involved had increased to $166,000 .^{25}$ Approximately two thirds of these household were engaged in the relatively simple craft production of coca paste, the base for cocaine ${ }^{26}$.

\footnotetext{
${ }^{21}$ Production has become more decentralized in response to law enforcement initiatives and especially counternarcotic aerial spraying with glyphosates. Hence, while most production is concentrated in small zones, these zones are spread out across 200 municipalities in 23 of Colombia's 32 departments; Mejía and Rico 2011: 19.

${ }^{22}$ The average plot size in 2002 was 2.2 hectares and 0.6 hectares in 2008; Mejía and Rico 2011: 22.

${ }^{23}$ González-Arias 1998: 52-54; Vargas 1999: 83

${ }^{24}$ UNODC World Drug Survey 2007, p. 176

${ }^{25}$ The increase in households does not indicate an increase in area of cultivation. In fact, UNODC data shows the area of illicit cultivation in Colombia decreased; Mejía and Rico 2011: 17.

${ }^{26}$ ibid
} 
Table 5.3, Structure of Coca Cultivation in Colombia ${ }^{27}$

\begin{tabular}{|c|c|c|c|c|c|c|}
\hline Year & 2000 & & 2001 & & 2002 & \\
\hline & \#Farms & Hectares & \#Farms & Hectares & \#Farms & Hectares \\
\hline Fields $<3$ hectares & 61,109 & 65,989 & 63,233 & 68,615 & 56,664 & 58,785 \\
\hline Fields $>3$ hectares & 11,956 & 84,919 & 10,413 & 67,724 & 6,292 & 35,687 \\
\hline
\end{tabular}

While most coca was grown on small farms, there were some commercial farms with illicit plantings of 25 to 200 hectares harvested by a transient population of paid laborers called raspachines. Planting, maintaining, and harvesting coca was a laborintensive activity. In 2008, an estimated 9,708,848 rural laborers worked in some activity having to do with illicit drug cultivation. The total value of this labor was estimated at $\$ 250,000$ million Colombian peso in 2008 . To give a sense of the economic impact of illicit drug production in Colombia, Table 5.4 provides more recent estimates of labor participation and the costs of production.

Table 5.4 Estimated Labor and Costs of Coca Production in Colombia, $2008^{28}$

\begin{tabular}{|l|c|c|}
\hline \multicolumn{1}{|c|}{ Task } & Estimated \# of laborers & $\begin{array}{c}\text { Cost } \\
\text { (millions of CO pesos) }\end{array}$ \\
\hline Land Preparation & 764,940 & 13,385 \\
\hline Planting & 823,781 & 15,240 \\
\hline Maintenance & $3,530,490$ & 76,612 \\
\hline Harvest & $4,589,637$ & 145,262 \\
\hline
\end{tabular}

${ }^{27}$ UNODC (2003) Colombia Coca Survey, p. 20

${ }^{28}$ Mejía and Rico 2011: 23 
Commercial farmers and peasant producers had different interests because the former had direct links and even some bargaining power vis-à-vis narcotics traffickers while the latter were at the mercy of chichipatos (merchant intermediaries or middle men) who would largely determine prices, then sell to traquetos. The traquetos are the links between the primary production stage and the drug trafficking syndicates. The loyalty of traquetos was to their employers, the narcotics traffickers. ${ }^{29}$

The traquetos delivered illicit coca to mobile laboratories called cocinas (kitchens) to be crystalized into cocaine proper. The process was carried out by specialists in laboratories that were owned and operated by drug traffickers. Processing cocaine required a large initial investment of upward of a million dollars for chemical inputs and equipment. ${ }^{30}$ Traffickers typically maintained multiple laboratories as a strategy for hedging against government suppression. In 2004, the Colombian government destroyed 243 cocaine laboratories in 21 Colombian departments and 163 in 19 departments in 2005. The Colombian Antinarcotics Division (DIRAN; Spanish acronym) estimated that the average cocaine laboratory produces between 300 and 500 kilograms of cocaine hydrochloride a week, or 26 metric tons a year. ${ }^{31}$

Finally, at the top of the illicit commodity chain are the Colombian crime syndicates that export cocaine to foreign markets. Powerful drug trafficking cartels have

\footnotetext{
${ }^{29}$ González-Arias 1998: 54

${ }^{30}$ The demand for chemical precursors to process coca paste and especially cocaine hydrochloride created a black market in chemical inputs such as acetone and ether, and the import of contraband fertilizers, herbicides and weapons. Mejía and Rico 2011: 17

${ }^{31}$ United Nations Office on Crime and Drug Control, 2007 World Drug Survey, p. 176
} 
operated in Colombia since the 1970 s when they were involved in the marijuana trade. ${ }^{32}$ The first cocaine export syndicates were loosely organized to minimize risk. However, in the 1980s control of the markets was consolidated under two mega-cartels in Medellín and Cali. ${ }^{33}$ A state crackdown in the early 1990s once again decentralized control. The two-cartel system broke down into a proliferation of smaller operations, the cartelitos. The 'baby cartels' could more effectively evade government suppression. From the baby cartels, the Norte del Valle network emerged from the remains of the Cali cartel as the largest and most powerful drug trafficking organization in Colombia. ${ }^{34}$

Colombian drug traffickers held control over most of the illicit drug market including international smuggling networks, money laundering operations, and even some distribution networks in the United States. However, narcotics traffickers have not monopolized control of the first and most important link in the illicit commodity chain, coca production. Rather, most illicit drug cultivation in Colombia fell under the control of insurgent organizations, most especially the FARC. ${ }^{35}$ During the 1980s, the FARC established strong ties with the peasant communities that cultivated coca by responding to the peasants' demands for protection against the ills of the drug trade, including breakdown of communities, violent crime, predatory traffickers, and aggression by the

\footnotetext{
${ }^{32}$ Illicit cultivation in marijuana preceded coca and opium poppy by a decade, and was concentrated in the Sierra Nevada de Santa Marta on the Caribbean coast; Thoumi 1995: 81.

${ }^{33}$ The Medellín cartel was controlled by six drug lords; the Ochoa Vasquéz brothers Jorge, Fabio and Juan David; Pablo Escobar Gaviria; Carlos Lehder Rivas; and José Gonzalo Rodríguez Gacha. The Cali cartel was led by two drug lords, Gilberto Rodríguez Orejuela and José Santacruz. Londoño; Felbab-Brown 2009: 76

${ }^{34}$ Decentralization of the Colombian illicit economy facilitated the dominance of Mexican drug trafficking cartels in the Western Hemisphere because the smaller cartels depended more on international networks to get their products to market.

${ }^{35}$ Thoumi 1995: 85, 94
} 
state. Caquetá was one community in which the FARC played a central role in the illicit economy.

\section{Caquetá and the Coca Bonanza}

The first boom in coca production in Colombia took place in the southeastern frontier region between 1978 and 1982. The department of Caquetá was at the center of the first coca bonanza. Caquetá was part of Colombia's vast unexplored national territory. During the 1940s and 1950, Caquetá was a colonization zone where thousands of Liberal and Communist peasants found refuge from economic hardship and violence in the more economically integrated central Andean departments. ${ }^{36}$ Most of the settlers that came to Caquetá were from the coffee-producing departments of Huila and Tolima. ${ }^{37}$ Between 1938 and 1951 the population of Caquetá grew 122 per cent from just 20,000 inhabitants to 46,588 . The colonists arrived to a virtually stateless region that was part of the vast Amazon, the slowest of all Colombian regions to incorporate into national markets. The Amazon region is isolated from the center of the country by economic and infrastructural barriers, and also by an enormous physical barrier; the mountains of the Cordillera Oriental. $^{38}$

Prior to colonization, most of Caquetá was controlled by one powerful family. The Lara family owned the Hacienda Lara, a 40,000 hectare ranch that provided almost

\footnotetext{
${ }^{36}$ It is estimated that a little more than half the peasant population that settled in Caquetá was from Huila, a department affected by civil disturbances during La Violencia. Other colonizers came from regions that experienced more intense and prolonged violence, including Tolima, Caldas and part of Valle and Cauca; Jaramillo, et al. 1989: 14; Uribe 2002.

${ }^{37}$ Uribe 2002: 205

${ }^{38}$ Author interview with Graciela Uribe in Bogotá Colombia, November 2011; Jaramillo, et al. 1989: 5
} 
all the employment in the region. The Laras resisted the colonization process, expelling peasant settlers from the most productive public lands surrounding their hacienda. As a result, the colonization process extended further and further into the jungles of the lower Caguán region, far from regional markets. Meanwhile, the government encouraged settlement to alleviate conflict in more integrated parts of the country. In 1958, a Rehabilitation Office was created that worked with the Agrarian Bank to title some 698,000 hectares of public land in Caquetá. Thousands of peasant settlers took advantage. However, without sufficient money for roads and communication infrastructure the colonists could not produce for markets. ${ }^{39}$

The way in which Caquetá was colonized explains why coca was such an attractive crop to the communities in the region. Indeed, the colonos took on debt when they settled in Caquetá, receiving loans from INCORA or the Caja Agraria for land and supplies. Economic conditions were harsh, and most families could not generate a surplus with traditional crops to pay their loans. Reliance on slash-and-burn methods to clear the dense jungle depleted soil fertility, and there was no money to purchase fertilizers to revitalize the soil. Hence, land quickly became unproductive, and the colonizers continuously moved to new plots, taking on more debt to start the process again. The

\footnotetext{
${ }^{39}$ Roughly 20,000 families were settled by direct government initiative, of which 15 per cent were sustained by INCORA. The other 85 per cent were spontaneous colonizers fleeing the violence and seeking to take advantage of the titling of public lands; Jaramillo, et al. 1989: 15-17.
} 
result was a vicious cycle of debt and migration deeper into the jungle and further from markets and the state. Illicit coca would later break that cycle. ${ }^{40}$

Despite economic hardship, the peasant communities that emerged from the colonization process were well-organized self-governing societies of small and medium holders. ${ }^{41}$ Prior to the arrival of the guerillas, two national peasant organizations were active in Caquetá; the National Agrarian Federation (FANAL) and the National Peasants Association (ANUC). Through ANUC, the colonos autonomously pressured for credit, debt relieft, land titles, and adjudication of conflicting land claims. In 1972, the peasants applied for and won a permanent banking presence (Agrarian Bank and INCORA). ${ }^{42}$ The peasants also organized through local Community Action Boards (JACs). The neighborhood JAC was the center of civic and political life. ${ }^{43}$ However, the authority of the JACs would later be challenged by the coca bonanza, which brought an influx of capital, crime, and violence to Caquetá.

It was in the context of recent settlement, debt, and strong community organizations that coca cultivation took root in Caquetá. In the late 1970s, narcotics traffickers from Medellín arrived in the lower Caguán region to distribute coca seeds to

\footnotetext{
${ }^{40}$ Author interview with Kyle Johnson, research associate with Corporación Nuevo Arco Iris, September 28, 2011 in Bogotá, Colombia; Author interview with Graciela Uribe, November 7, 2011 in Bogotá, Colombia.

${ }^{41}$ In 1983, INCORA sampled 25 per cent of the population in the municipality of Cartagena de Chairá in Caquetá and found that 44 per cent owned properties of less than 100 hectares, 31 per cent had properties between 100 and 200 hectares, and only 7 per cent had a property of more than 200 hectares; Jaramillo, et al. 1989: 39-41.

42 Uribe 2002: 215; Author interview with Kyle Johnson, research associate with the Corporación Arco Iris, September 28, 2011, Bogotá, Colombia.

${ }^{43}$ In Colombia the political party was a basic unit of political socialization and electoral recruitment within an institutionalized bipartisan system. However, in Caquetá there is no evidence of political organization along party lines. Author interview with Graciela Uribe, November 7, 2011 in Bogotá, Colombia.
} 
communities of peasant settlers. ${ }^{44}$ Coca cultivation was at first undertaken very quietly. According to local testimonies, the first seeds were supplied to the peasants at no cost, and the traffickers returned and paid 1,200 pesos per gram of raw coca leaf. After the initial cultivation and profits, the settlers began to sell what they had in order to afford more seed. They sold their poultry, livestock, and even their parcel of land. New jungle was cleared and burned explicitly for the purpose of planting more coca. ${ }^{45}$

Even in isolated Caquetá, illicit cultivation was risky business. However, the peasants accepted the risk because coca was a way out of extremely harsh economic conditions. The average coca cultivator invested roughly 200,000 pesos to produce a few hectares of coca that they then sold for about 1,000,000 pesos in 1978, an unimaginable profit margin for a subsistence peasant farmer. ${ }^{46}$ As one scholar and expert on Caquetá explained, "A new coca plant in full production can provide between 5.4 and 6.7 kilograms of [coca] paste a year, with a price that varies [in 1978] from 800,000 to $1,200,000$ pesos per kilogram. Based on these estimates, the profitability of one hectare a year during the period of the bonanza ranged from 3.8 to $\$ 5.9$ million pesos." ${ }^{\prime 4}$

By the late 1970s, peasant coca cultivators were selling directly to merchant intermediaries who worked for powerful drug capos like Gonzalo Rodríguez Gacha (El mexicano) and Carlos Leder. For the most part, the drug traffickers remained outside the

\footnotetext{
${ }^{44}$ Puentes Marín 2006: 25. According to the testimonies of illicit coca farmers in El Caguán, narcotics traffickers provided seed and then paid illicit cultivators COL $\$ 1,200$ per gram of coca leaf; Jaramillo, et al. 1989: 42, footnote 10 .

${ }^{45}$ Author interview with Graciela Uribe, November 7, 2011 in Bogotá, Colombia; Author interview with Kyle Johnson, research associate with the Corporación Nuevo Arco Iris, September 28, 2011 in Bogotá, Colombia; Jaramillo, et al. 1989: 42, 141.

46 Author interview with Kyle Johnson, research associate with the Corporación Nuevo Arco Iris, September 28, 2011, Bogotá, Colombia.

${ }^{47}$ Jaramillo, et al. 1989: 145
} 
areas where coca was cultivated. Traffickers tended to launder their illicit profits outside of cultivation zones, purchasing land in more economically active regions of Colombia such as the Magdalena Medio and Caribbean. However, traffickers set up laboratories and airfields close to the cultivation zones including large haciendas in Meta and Vichada. Perhaps the most famous coca plantation south of Bogotá was Tranquilandia which was established by the Medellín cartel in Caquetá in the 1980s but then later abandoned. The traffickers had private armies to protect the illicit crops, laboratories, and properties.

\section{Coca and Social Transformation in Caquetá}

The coca bonanza initiated a socio-political transformation in Caquetá that created tremendous social turmoil. Practically overnight, the region of the lower Caguán was flooded with fortune seekers, guns, and rapidly escalating crime and violence. Most came to cultivate coca, others to work the coca fields. According to the 1993 population census, there were 105,513 immigrants from other departments in Caquetá, whomade up 33.9 per cent of the total population of the department. An additional 63,385 inhabitants or 20.3 per cent of the population were identified as 'internal immigrants' moving from one municipality to another. ${ }^{48}$

Indeed, the intense migration from towns to rural areas resulted in a true 'demographic revolution' in the lower Caguán that transformed the socially and economically homogenous region into a stratified society. The growth of the coca economy marked the integration of frontier communities into the globalized economy.

${ }^{48}$ National Administrative Department of Statistics (DANE) in Colombia, National Census 2003: www.dane.gov.co 
Capitalist relations created social differentiation expressed through a division of labor; jornaleros, peasant land owners, and medium producers. ${ }^{49} \mathrm{~A}$ booming tertiary sector also developed, with a class of merchants who were the owners of stores, dance clubs and bars. Finally, a speculative comercial sector resulted in numerous comercial centers supported by the investment of coca money by newly arrived merchants, coca growers, and jornaleros. ${ }^{50}$

The socio-economic changes that accompanied coca dramatically increased the incomes and living standards of the local population in El Caguán, Caquetá. However, the overall economic outcome was indisputably negative. Within the first two years, local farmers had replaced all of their subsistence crops with coca, creating a dependence on imported food at inflated prices due to the excessive liquidation and pressure on the incipient commercial sector. Even river transport became commercialized as paddle canoes operated by individuals were replaced by motor boats operated by businesses. ${ }^{51}$ Finally, the demographic revolution brought new interests to the region, and conflicts emerged. Some of these conflicts turned violent and the peasant communities had little recourse.

\section{Coca and Conflict in Caquetá}

Coca generated two types of conflict in Caquetá that caused tremendous violence in the region and threatened to undermine the solidarity of the peasant communities.

\footnotetext{
${ }^{49}$ The division of labor did not result in significant land concentration until a fall in coca prices after 1982 led many smallholders to sell their properties at low prices; Uribe, 2002: 204, 217; Jaramillo, et al. 1989:58; Author interview with Graciela Uribe, November 7, 2011 in Bogotá, Colombia.

${ }^{50}$ Jaramillo, et al. 1989: 60

${ }^{51}$ ibid: 147
} 
First, coca attracted a new population of fortune seekers who had no roots in the region and whose interests conflicted with those of the settled peasant population. Second, coca brought narcotics traffickers and their merchants to Caquetá. The narcotics traffickers monopolized the local coca market unrestrained by state institutions. Hence, traffickers often used threats and intimidation to exact lower prices from producers.

First, conflicts emerged between the distinct social groupings that developed in Caquetá as a result of the coca boom. Prior to coca, the lower Caguán region was a homogenous society of subsistence peasants. After coca, four distinct social sectors coexisted in the region: traditional settlers with a permanent homestead who engaged in coca as part of this economic establishment alongside legal cultivation and ranching; settlers who had come because of the coca business whose only objective was fast enrichment in order to later establish themselves outside of the zone; merchants linked to coca paste trafficking rings who remained only for the duration of the bonanza; and coca harvesters who had no roots in the zone. ${ }^{52}$

Not surprisingly, the temporary workers and merchants that made up the 'floating population' behaved in ways that reflected their short time horizons, which put them in conflict with the settled peasant communities. The floating population, or flotadores as they were called, cleared the jungle without any interest in local conservation efforts. While INCORA was offering free land titles, hardly any flotadores were interested in permanent settlement. These proprietors, harvesters, merchants, and domestic workers simply moved in, constructed temporary makeshift dwellings and remained only long

\footnotetext{
${ }^{52}$ Author interview with Graciela Uribe, November 7, 2011 in Bogotá, Colombia
} 
enough to make money. They were in many cases people with urban backgrounds and a speculative mentality that contrasted with the peasant entrepreneur investing in land and agricultural production to build a permanent home and live in a community with schools, roads, security, and health clinics. ${ }^{53}$

The consumption habits of the floating population were of particular concern for the settled population. There was a proliferation of night clubs and bars with all the undesirable social behavior that followed. Alcohol consumption was on the rise, as was prostitution. Cartagena del Chairá, the main town in the lower Caguán region, was 'literally inundated with bars and dance clubs.' In 1986, there were only about 500 households in Cartagena del Chairá, yet there were an estimated 400 prostitutes in the town center. ${ }^{54}$ The floating population frequented the bars and brothels, and settled disputes with neighbors and workers with violence. ${ }^{55}$ The tremendous increase and crime and violence during the first coca bonanza was attributable to the activities of this population.

Second, conflicts developed between peasant cultivators on the one hand and narcotics traffickers, intermediaries and commercial coca farmers on the other. The exchange between peasant cultivators and merchants was highly asymmetrical. Narcotics traffickers monopolized markets and set prices. The intermediaries that purchased raw coca worked for the narcotics traffickers. Coca had little value unless it was chemically process into coca paste, the base for cocaine. Narcotics traffickers cartelized knowledge

\footnotetext{
${ }^{53}$ Author interview with Graciela Uribe, November 7, 2011 in Bogotá, Colombia

${ }^{54}$ Jaramillo, et al. 1989: 62-63

55 Author interview with Graciela Uribe, November 7, 2011 in Bogotá, Colombia
} 
of the relatively simple steps by which coca became coca base as a method for keeping prices low. Later on, the FARC trained peasant cultivators to make coca base, and turned base production into a peasant cottage industry. ${ }^{56}$

For their part, the commercial coca farmers were not formally linked to the narcotics traffickers. However, the interests, external attachments, and economic force of commercial coca farmers put this sector in conflict with local community organizations that represented the interest of settled peasants. Commercial coca farmers were an emerging power in the region that was reluctant to contribute capital or participate in the community organizations that were attempting to overcome collective action problems in order to achieve development through self-governance. ${ }^{57}$

Of course, all of these conflicts were exacerbated by the volatility of coca prices. Coca behaved like an extractive economy and hence while the social impact was clear from the beginning, the economic dangers of coca only became apparent in the wake of the first price bust. In 1982, the price of coca in Caquetá plummeted because of a myriad of factors including increased in production in other Colombian regions, the dismantling of some narcotics trafficking chains due to state crackdowns, and the growing threat of military takeover in the region, which restricted transport and increased the cost of bribes that had to be paid to local authorities. ${ }^{58}$

\footnotetext{
56 Author interview with Kyle Johnson, research associate with the Corporación Nuevo Arco Iris, September 28, 2011, Bogotá, Colombia

57 Jaramillo, et al. 1989: 125

${ }^{58}$ Author interview with Graciela Uribe, November 7, 2011 in Bogotá, Colombia; Jaramillo, et al. 1989: 148
} 
What is more, coca price fluctuations were accompanied by massive population movements in and out of the lower Caguán. Migration coupled with speculation and narcotics traffickers' tendencies to launder their profits elsewhere, meant that most of the capital generated by coca did not remain in the El Caguán region. The exit of the floating population during price busts was particularly devastating because this population was spending and investing in leisure activities. When they left, they took a lot of capital out of the local economy and left behind only inflated food prices and disorder. Crops were abandoned, and the inability to pay workers resulted in homicides and forced disappearances. To make matters worse, the communities no longer produced their own food and so had to purchase imported food at inflated prices. Large sectors of the population who had previously enjoyed unprecedented wealth were suddenly impoverished. ${ }^{59}$

In 1984, Colombian Minister of Justice Rodrigo Lara Bonilla was assassinated by the Medellín drug cartel. The event marked a turning point in the state's approach to drug traffickers. A heavy state crackdown dismantled supply routes, generating a rapid increase in the price of coca to 500,000 pesos per kilogram. In Caquetá, conditions improved. The population returned to the lower Caguán, as did commerce, services, and the transportation sector. ${ }^{60}$ Nevertheless, community leaders in El Caguán understood that the community remained in a precarious position. In addition, even as coca prices improved, crime and social disintegration had transformed the region into a Colombian

\footnotetext{
${ }^{59}$ Author interview with Kyel Johnson, researcher at Corporación Nuevo Arco Iris, September 28, 2011 in Bogotá, Colombia

${ }^{60}$ Jaramillo, et al. 1989: 151-152
} 
'wild west.' Community leaders organized and began soliciting the national government for support in implementing a development plan for the lower Caguán that would replace coca with profitable and licit alternatives.

After a promising period of open talks between community leaders in Caquetá and Colombian President Belisario Betancur, the national government rejected the El Caguán development plan. In place of aid, the government declared Caquetá a 'red zone' (high-conflict zone) and formally excluded the department from government assistance. The military was sent in and a campaign of forced eradication of coca crops was soon underway. Caquetá and similar regions were defined as a threat to the national interest. Before turning to an explanation of the state's repressive policies, the following section describes the forces driving the state's interest in repressing coca.

\section{II. . The National Interest: The Securitization of the Coca Problem}

In this section, I describe the two key factors that contributed to the state repression of coca producers in Colombia. First, precisely because it was illicit, coca was a source of rents and political autonomy for insurgents at war with the state, but the state could not access licit rents to build a defense. Further, legalizing coca in order to access rents was problematic because of the security agenda of the United States. Hence, the second factor that led to repression of coca in Colombia was the United States' use of carrot and stick policies to pressure foreign governments into cooperating with the U.S. supply-side war on drugs. From the perspective of the U.S., there was no distinction between the cartels at the top of the illicit commodity chain and the illicit producers at the bottom; both were criminal actors. U.S. pressure significantly narrowed the set of 
practicable policy options available to the Colombian government to address illicit drug production.

\section{The Coca-Security Nexus}

If the Colombian national interest vis-à-vis oil was shaped by the tremendous wealth that flowed back to the state, then it was the tremendous wealth flowing to insurgents that shaped the national interest with respect to coca. Mejía and Restrepo estimate that between 2000 and 2008 the Colombian government spent $\$ .032$ on security measures to combat the insurgents for every dollar that the FARC gained from drug production. Conversely, the government spent only $\$ 0.13$ for every dollar obtained by drug traffickers. Hence, the Colombian government calculated that illicit production cost the government more than drug trafficking and this shaped state policy in favor of targeting producers. ${ }^{61}$

The illicit economy is at the center of the 'economic war system' that actually makes war and violence a profitable activity in Colombia. ${ }^{62}$ Hence, one cynical interpretation of the reluctance of Colombian insurgents to demobilize after sixty years of war is that there is a strong economic incentive to keep on fighting. It is certainly the case that the FARC has gained military and political power at the expense of the state because of the presence of illicit coca. Coca has supplied the FARC with resources to purchase arms and bring in new recruits. Coca was also the basis for the FARC's unusual level of political autonomy since the insurgents did not depend on alliances with legal actors and

\footnotetext{
${ }^{61}$ Mejía 2012: 26
}

${ }^{62}$ Richani 2002 
institutions for access to rents. Meanwhile, the drug trade brought the Colombian state to the brink of collapse in the early 1990s.

In 1999, FARC leaders sat down at the negotiating table with Colombian President Andrés Pastrana (1998-2002) having the upper hand. They were a militarily formidable force that dominated the state on the battlefield. Had they demobilized in 1998, it is likely the FARC would have won significant concessions including amnesty, protected reintegration back into civilian life, and perhaps even some of the social and economic reforms that they were purportedly fighting for. And yet, in 1998 the FARC went back to waging war. The FARC's decision to continue the war may have been partly motivated by economic factors. However, Mauricio Romero argues that a major contributing factor was the FARC's fear that the state was too weak to offer protection against paramilitaries and their drug trafficking allies. ${ }^{63}$ Both groups had infiltrated the state at all levels, controlling officials and policy agendas with drug money and threats of violence. Indeed, the very same economic forces that made the FARC strong had undermined the capacity of state institutions to enforce the law and subsequently to protect a demobilized FARC against their narcotics trafficking and paramilitary enemies.

After the first coca boom began in 1979, the FARC transformed into a remarkable military machine. This transformation was not limited to an increase in the number of weapons and combatants, but also included real gains in military capacity owing to the militarization of organizational objectives. ${ }^{64}$ Twenty years after the attack on

\footnotetext{
${ }^{63}$ Romero 2003

${ }^{64}$ Ferro and Uribe 2002; Ortiz 2002; Pécaut 2008; Pizarro 2011
} 
Marquetalia, the 48 men who made up the original FARC had grown into 45 fronts. Armed with illicit rents, the growth and territorial expansion of the FARC continued unabated until 2004. The FARC grew from 32 fronts and 3,600 fighters in 1986 to 60 fronts and 7,000 fighters in 1995, and finally 18,000 fighters in 2001 with control over about 40 per cent of Colombian territory. To be sure, the FARC is by far the largest guerilla organization in the history of Latin America and one of the largest in the world. ${ }^{65}$ The FARC's growing military capacity was evident as early as 1988 when the insurgent group resisted state incursions against their stronghold in the lower Caguán region of Caquetá as part of Operation Alfa Justiciera which was launched on June 30 of that year. During Operation Alfa Justiciera, the military hierarchy announced their intention to eliminate coca from the lower Caguán. ${ }^{66}$ However, it was not until the early 1990s after another failed round of peace negotiations that the FARC really began to demonstrate military power. In 1991, Colombian President César Gaviria (1990-1994) successfully negotiated the demobilization of several Colombian insurgent groups, including the $19^{\text {th }}$ of April Movement (M-19), the Popular Liberation Army (EPL), and the Corriente Socialista, the political wing of the ELN. ${ }^{67}$ The FARC participated in the peace talks, but did not demobilize.

\footnotetext{
${ }^{65}$ No other Latin American insurgent organizations is comparable to the FARC in terms of number of combatants. Other significant organizations include the Guatemalan National Revolutionary Unity (URNG) which peaked at 6,000 fighters, the Salvadorian Farabundo Martí National Liberation Front (FMLN) with 8,000 combatants, and the Peruvian Shining Path (SL) with 10,000 fighters; Richani 2002: 74; McClintock 1998: 73.

${ }^{66}$ Uribe 2002: 222

${ }^{67}$ Celis 2010
} 
In response to the FARC's return to the battlefield, Gaviria stepped up the state's military campaign against the insurgents. The FARC responded by carrying out large scale military operations involving 300 to 600 combatants against military bases in Las Delicias, Patascoy, San Miguel, and Puerres between 1996 and $1997 .{ }^{68}$ Between 1998 and 2000, the FARC had uncontested control over a demilitarized zone in Caquetá and Meta as a condition for yet more talks with the government. However, even while peace and disarmament discussions were taking place, the FARC used their position in the demilitarized zone to attack surrounding police and military installations, and to take military 'prisoners of war.'

In 2000, in an outstanding display of FARC bargaining power vis-à-vis the state, the insurgents negotiated the release of 452 captured FARC combatants in exchange for 528 military and police held by the FARC in the demilitarized zone in Caquetá. ${ }^{69}$ In contrast, the ELN, an insurgent group armed with oil rents, was hardly a match for the State. The ELN targeted police posts far more than it did military outposts.

Table 5.5, FARC Attacks against Colombian Military, 1996-199970

\begin{tabular}{|c|c|c|c|c|c|}
\hline Year & Location & $\begin{array}{c}\text { FARC } \\
\text { fighters }\end{array}$ & $\begin{array}{c}\text { FARC } \\
\text { deaths }\end{array}$ & Army deaths & $\begin{array}{c}\text { Army } \\
\text { prisoners }\end{array}$ \\
\hline 1996 & Puerres & 300 & $n a$ & 31 & \\
\hline 1997 & Delicias & 1000 & $n a$ & 62 & 32 \\
\hline 1997 & Delicias & 400 & $n a$ & 27 & 60 \\
\hline 1997 & San Juanito & 300 & 12 & 16 & \\
\hline
\end{tabular}

\footnotetext{
${ }^{68}$ Richani 2002: 77

${ }^{69}$ Currea-Lugo 2007: 108-109

${ }^{70}$ Richani 2002: 130
} 


\begin{tabular}{|c|c|c|c|c|c|}
\hline 1997 & Patascoy & 400 & $n a$ & 17 & 18 \\
\hline 1998 & Juan Jose & 300 & 15 & 35 & \\
\hline 1999 & Gutierrez & 500 & 35 & 37 & \\
\hline 1999 & Casanare & 300 & 50 & $n a$ & \\
\hline
\end{tabular}

In addition, beyond military power, coca also provided the FARC with a great deal of economic and therefore political autonomy to supplant the state at the local level. Rather than exercise power through existing institutions, in coca-growing regions the FARC constructed autonomous institutions through which they controlled the locals. The FARC's autonomy was the result of their involvement in an informal economy because accessing rents did not require alliances with legal actors or institutions. Contrast this with the ELN's strategy in Arauca. To access oil rents, the ELN embedded within local state institutions in order to control public coffers because that was where oil royalties were located. Hence, oil bred corruption between local officials and insurgents. Conversely, the FARC, armed with illicit rents, explicitly adopted a law against corruption that threatened to punish corrupt officials with expropriation of property or kidnappings. $^{71}$

The FARC's capacity to autonomously and directly govern, which derived from the insurgents' relationship with the coca economy, made the FARC a far greater threat to the Colombian government. Where the FARC has participated in politics, they have done so through autonomous organizations and political parties such as the Patriotic Union. The Patriotic Union was electorally successful until the party's membership was

${ }^{71}$ Currea-Lugo 2007:113 
annihilated by paramilitaries in the late 1980s for being the party of the FARC. On April 29, 2000, the FARC officially launched a new party, the Bolivarian Movement, in Caquetá. Reportedly, more than 31,000 locals attended the event despite the efforts of the $7^{\text {th }}$ Military Brigade to set up roadblocks. ${ }^{72}$ The most recent version of the Bolivarian Movement is the Clandestine Colombian Communist Party (PCCC) which is entirely under the control of the FARC military hierarchy. ${ }^{73}$

Due to their greater autonomy, the FARC has been far more likely to use violence to evict the state from their areas of influence than other insurgent groups in Colombia. Popularly elected local officials have been forced to renounce their office to be replaced by FARC-appointed leaders. Following the dissolution of peace talks between the FARC and the government in 2000, a number of high profile political assassinations and kidnappings took place that were attributed to the FARC. In December 2000 congressman and head of the congressional peace commission Diego Turbay Cote was assassinated along with five companions while traveling to a political meeting in Puerto Rico, Caquetá. Not long after, ex-minister Fernando Araújo and the daughter of the President of the National Association of Entrepreneurs (ANDI) Luis Carlos Villegas were kidnapped in Caquetá. ${ }^{74}$ The distinct effects of oil and illicit coca on insurgent relations with the state is captured by the data on FARC and ELN violence toward the political class. $^{75}$

\footnotetext{
${ }^{72}$ Lozano (2000) Por aquí viene mucho pueblo, in VOZ No. 2037, March-April 2000

${ }^{73}$ Currea-Lugo 2007: 109

${ }^{74}$ Lozano (2001) Las acusaciones de los altos mandos militares son temerarias, in VOZ no. 2077, pp. 17-23, January 2001

${ }^{75}$ Ávila Martínez 2011: 17
} 
Table 5.6, Violence against Political Class by FARC and ELN, 1997-2007 ${ }^{76}$

\begin{tabular}{|c|c|c|}
\hline Year & FARC & ELN \\
\hline 1997 & 505 & 75 \\
\hline 1998 & 217 & 139 \\
\hline 2000 & 71 & 49 \\
\hline 2002 & 207 & 36 \\
\hline 2003 & 108 & 13 \\
\hline 2006 & 49 & 3 \\
\hline 2007 & 83 & 3 \\
\hline Total & 1240 & 318 \\
\hline
\end{tabular}

\section{The United States War on Drugs}

The second factor contributing to government repression of illicit drug production in Colombia was the security agenda of the United States regarding the international drug trade. On October 14, 1982, United States President Ronald Reagan declared illicit drugs and their production a threat to the security of the United States. Reagan's declaration and the policies that followed ignited President Richard Nixon's 'War on Drugs' that had begun a decade earlier but without a clear strategy. ${ }^{77}$ Reagan's decision to target the drug problem was a response to a deepening public fear in response to the so-called 'scourge of crack cocaine' that was sweeping across the United States. By 1988, 48 per cent of Americans considered combating drugs to be the most important challenge facing the United States, even more important than combating communism. ${ }^{78}$ In response, Reagan created the Office of National Drug Control Policy to coordinate the fight against illicit

\footnotetext{
76 ibid; data from the Colombian National Police

77 Ayling 2005: 376

${ }^{78}$ Crandle 2001: 100
} 
drugs both domestically and internationally. The director of the Office was dubbed the drug czar, and the position was elevated to cabinet level under President Bill Clinton. ${ }^{79}$

During the 1980s, the problem of drug abuse in the United States was a domestic issue, but one with foreign origins. The most commonly used drugs, including cocaine and heroin and to a lesser extent marijuana, were cultivated and processed outside of the United States. Hence, drugs and drug-related crime constituted a foreign-born security threat to U.S. public health and safety. The drug problem was defined as a national security issue and this justified a policy of U.S. pressure and interference in the drug policies of producer and transit countries. Moreover, because drugs were a threat to national security, the U.S. was committed to combating the problem with economic and military coercion. Hence, by the mid-1980s the drug war had shifted from demand-side to supply-side solutions. ${ }^{80}$ The linchpin of supply-side drug policy was the Certification Process, which began in 1986.

The Certification Process was a tool used to ensure the compliance by drug producer and transit countries in the war against drugs. Certification worked (and continues to work) as follows. Every November, the President of the United States was required to provide a list to Congress. The list was known as the 'Majors List' and it included all of the major drug-producing and drug-transiting countries. Between November and March, the executive branch prepared an International Narcotics Control Strategy Report (INCSR) for Congress that identified each of the countries on the Majors List and included information on illicit drug cultivation, manufacturing, and trafficking in

\footnotetext{
${ }^{79}$ Politico, October 14, 2010, Retrieved online: http://www.politico.com/news/stories/1010/43552.html
}

${ }^{80}$ Fukumi 2008: 77-106 
those countries. The INCSR also included an assessment of the country's efforts to combat illicit drugs, and to address drug-related government corruption. After 1988, country efforts were measured by the objectives of the United Nations Convention against Illicit Traffic in Narcotic Drugs and Psychotropic Substances that went into effect that year. ${ }^{81}$

By submitting the INCSR report to Congress each year, the President 'certified' that during the previous year each country on the list "has cooperated fully with the United States, or has taken adequate steps on its own to achieve full compliance with the goals and objectives of the 1988 Convention." 82 Beyond the Convention, the President also considers the country's performance on anti-narcotics goals set by bilateral narcotics agreements. A handful of countries found not in compliance can be certified by applying the 'national interest waiver' which says that a country not meeting standards could be certified if the President determined that it was vital to U.S. interests. ${ }^{83}$ However, all decertified countries faced harsh economic consequences.

The main tool used in the certification process was economic coercion. Decertified states were subject to a long list of economic penalties for not complying with U.S. drug war policies. First, a decertified country lost bilateral assistance from the United States. In fact, the U.S. withheld 50 per cent of bilateral assistance to all countries on the Majors List until the country was certified. Second, the decertified country lost

${ }^{81}$ Fukumi 2008: 143; Ayling 2005: 377

82 There is a long list of international agreements, conventions and declarations through which the U.S. has expressed or enforced its drug war agenda on producer countries including the Commission on Narcotics and Drugs (CND), the UN office on Drugs and Crime (UNODC), and the World Health Organization (WHO); Ayling 2005: 377; Fukumi 2008: 142-144.

${ }^{83}$ Ayling 2005: 377 
multilateral development assistance. The U.S. would instruct their representative at the multilateral development banks to vote against any loan to or other utilization of the bank's funds for decertified countries. Aid sanctions would be lifted only when the country was once again certified. ${ }^{84}$

Finally, the United States punished decertified states with trade sanctions. Under the Narcotics Trade Act of 1974, the President is required to do all or the following in the case of a decertified country on the Majors List: deny preferential tariff treatment, curtail air transport between the United States and the decertified country, withdraw United States customs resources from the country, and apply up to 50 per cent additional duties on duty free and dutiable products. ${ }^{85}$

Between 1986 and 1996, Colombia was consistently certified by the United States as a complying country. Despite the increasing amount of cocaine entering U.S. markets from Colombia, the United States government considered that Colombia was its best ally in the war against drugs. ${ }^{86}$ However, in 1996 and 1997 Colombia was decertified because of evidence that Colombian President Ernesto Samper (1994-1998) had received campaign contributions from the Cali Drug Cartel. In response, the U.S. came down on

\footnotetext{
${ }^{84}$ The multilateral banks included the International Bank for Reconstruction and Development, the International Development Association, the Inter-American Development Bank, the Asian Development Bank, the African Development Bank, and the European Bank for Reconstruction and Development; Ayling 2005: 377-378.

85 Ayling 2005: 378; also see K. Larry Storrs "Drug Certification/Designation Procedures for Illicit Narcotics Producing and Transit Countries" Congressional Research Service Report for Congress, September 22, 2003

${ }^{86}$ See comments from the United States General Accounting Office (GAO), The Drug War: Counternarcotics Programs in Colombia and Peru, Statement of Joseph E. Kelley, Director of Security and International Relations Issues, National Security and International Affairs Division before the Subcommittee on Terrorism, Narcotics and International Operations, Committee on Foreign Relations, U.S. Senate, on February 20, 1992
} 
Colombia in full force, cutting Colombia off from U.S. bilateral aid and even revoking President Samper's visa in July of $1996 .^{87}$

The loss of U.S. assistance was devastating for Colombia because the country depended on U.S. aid in their war against insurgents. Mejía and Restrepo estimate that between 2000 and 2008, the United States was funding about 57 per cent of the costs of eradication of illicit crops and about 64 per cent of the cost of interdiction efforts in Colombia. ${ }^{88}$ In addition, the United States was quite flexible in allowing Colombia to use counter-narcotics aid to fight insurgents. Beginning in 1989, the U.S. provided direct military, law enforcement, and military aid to Colombia, Peru, and Bolivia as part of President George H. Bush's anti-narcotics plan, called the Andean Strategy. Between August 1989 and September 1990, Colombia received \$271 million in counter-narcotics aid for military and law enforcement which included \$65 million in emergency aid, \$122 million in grant aid, and $\$ 84$ million in loan guarantees. In a 1992 statement before the U.S. Senate, the United States General Accounting Office noted that Colombia was given considerable flexibility to use U.S. narcotics aid against insurgents:

The policy of using counternarcotics aid against the insurgents involved in drug trafficking activities has been reasonable. The Defense and State Departments have sufficient evidence that insurgent groups are linked to the drug trade. In addition, Colombian and U.S. officials believe it would be difficult to achieve U.S. counternarcotics objectives if they could not use the aid to stop insurgents' drug related activities. Colombian police told us that they had frequently used U.S. aid against insurgents during drug raids. ${ }^{89}$

${ }^{87}$ Crandall 2001: 95

${ }^{88}$ Mejía 2012: 25-26

${ }^{89}$ U.S. GAO, The Drug War: Counternarcotics Programs in Colombia and Peru, Statement of Joseph E. Kelley, Director of Security and International Relations Issues, National Security and International Affairs Division before the Subcommittee on Terrorism, Narcotics and International Operations, Committee on Foreign Relations, U.S. Senate, on February 20, 1992 
Indeed, decertification by the United States threatened to undermine the war effort against insurgents in Colombia. Hence, following decertification the Colombian government stepped up efforts to combat the drug trade to demonstrate compliance with the U.S. war against drugs by cracking down not just on narcotics traffickers, but also illicit drug cultivators. Hence, as a direct response to the U.S. decertification in 1996 and 1997, the Samper administration increased aerial spraying of coca farms in the Amazon region. The department of Caquetá was among the zones targeted for aerial spraying. This increased enforcement devastated the region economically, and was the main precursor to a ten-month period of protests in which 200,000 peasants demonstrated against government forced eradication efforts in Putumayo, Caquetá, and parts of Amazonian Cauca. ${ }^{90}$

The Colombian government's crackdown on illicit producers resulted in the certification of Colombia by the U.S. government in 1998. Moreover, in the summer of 2000, the United States approved a $\$ 1.3$ billion assistance package for Colombia in support of Plan Colombia, a counter-narcotics plan proposed by Colombian President Andrés Pastrana (1998-2002). Plan Colombia called for a strong military response to the drug problem. The cornerstone of Plan Colombia was increased forced eradication with glyphosate spraying in areas with significant coca cultivation. Chemical spraying was a controversial policy with questionable human rights implications. It was at the center of

\footnotetext{
${ }^{90}$ Ramírez 2003
} 
the State's repressive response to coca, and its primary target was not drug traffickers nor insurgents but the peasant farmers producing coca.

\section{III. . The State Response: Political Abandonment and Repression}

The United States 'War on Drugs' dictated that the Colombian government treat coca as an illicit commodity, and this being so, the state could neither tax nor regulate coca. The illicitness of coca made it highly lucrative, and hence a reliable source of rents for insurgent organizations such as the FARC. Under these conditions, the Colombian government was left with a narrow set of viable policy options to combat the problem of drug cultivation. Meanwhile, drug violence ravaged the country in the 1980 s and especially the 1990s. In fact, the only practicable policy was to repress the illicit economy and criminalize the populations that produced, marketed and trafficked illicit coca.

In Colombia, government repression of coca cultivation was pursued in place of alternative development solutions favored by the communities that produced coca. Almost as soon as the first coca bonanza got underway in 1979, the colonos communities of Caguán were in favor of coca eradication. The same farmers that cultivated coca requested the state to support development that would make legal alternatives to coca profitable. Coca threatened to undermine the community projects that the colonos had established decades earlier. Initially, President Belisario Betancur was enthusiastic about the El Caguán development plan. However, in 1986, the same year that the United States adopted the Certification Process, the Colombian government abandoned the El Caguán Development project. A year later the Colombian government declared Caquetá a 'red 
zone.' Rather than combat coca with development, the national government instead relied on a militarized campaign of forced eradication to repress the illicit economy.

\section{Political Abandonment}

Mr. President, if we obtain your support, you can be sure that Caquetá, in addition to being a model [of development], will always be a land of peace." 91

In 2001 a Spanish journalist named Eduardo Soto-Trillo traveled to San Vicente del Caguán, capital of the department of Caquetá. At that time, the Colombian government had ceded military control of San Vicente to the FARC as a concession for peace negotiations. Soto-Trillo talked to the mayor and with civilians about life in San Vicente. What he found was surprising. Despite the impressive order obtained under the FARC, there was almost unanimous support for a greater state presence. As Soto-Trillo describes it, locals expressed a feeling of abandonment by their government. They pointed to the complete lack of funds to improve social conditions in San Vicente, and to send their children to school. The mayor of San Vicente explained that in light of this abandonment, he welcomed the FARC because they provided desperately needed public services. He did so, he explained, for the common good in San Vicente. ${ }^{92}$

In 1987, in an outright act of political abandonment, the Colombian government formally excluded Caquetá and other coca-producing departments from national development funds. Caquetá was declared a 'red zone.' This policy reinforced the structural marginality of the Amazon region and stigmatized the populations within the region as narco-cultivators hardly distinguishable from narcotics traffickers. The

\footnotetext{
${ }^{91}$ The opening line of a letter sent in 1985 addressed to Colombian President Belisario Betancur from the Colonization Committee of El Caguán, Caquetá; Jaramillo, et al. 1989: 200.

${ }^{92}$ Soto-Trillo 2001: 112-113
} 
criminalization of illicit cultivators in Colombia significantly hindered cooperation between the state and local communities in dealing with the problem of drug cultivation, including the violence that the drug trade provoked at the national level. ${ }^{93}$ What is worse, the policy further delegitimized the authority of a historically neglectful state in a way that drove the peasants closer to the FARC. ${ }^{94}$

For the communities of the lower Caguán region of Caquetá, political abandonment followed several years of negotiating with the central government to eradicate coca and improve social conditions. In 1984, Colombian President Betancur and the FARC signed the Uribe accords which called for a ceasefire and the beginning of peace talks. A space opened up for the insurgents and the community to address the problem of coca in El Caguán with their government. That year, the FARC created two committees in El Caguán: the Colonization Committee and the Committee for Research and Technology Transfer. The Colonization Committee was tasked with distributing and adjudicating land claims. The Committee for Research was tasked with identifying new crops and production systems that might offer a solution to economic hardship so that coca could be eradicated without undermining the livelihoods of the peasant producers. The joint purpose of the committees was to work with the Community Action Boards (JACs) and local state institutions to create a development plan for the region which would lead to the eradication of illicit coca crops. ${ }^{95}$

\footnotetext{
${ }^{93}$ Jaramillo, et al. 1989: 128; 165

${ }^{94}$ Ramírez 2003

${ }^{95}$ Uribe 2002: 223
} 
During the period in which the Uribe Accord was in effect, the state was present in the lower Caguán through organizations such as INCORA and the Agrarian Bank. Representatives of INCORA participated with the FARC, representatives of the JAC, and representatives of the central and departmental governments in devising a development plan. ${ }^{96}$ It was a time of open collaboration between the FARC, the community, and the state. As a result, President Belisario Betancur declared the El Caguán municipality of Cartagena de Chairé a 'model of development. ${ }^{97}$ A symbolic event that took place during this era was the government's lifting of the forest reserve in response to local demands. The forest reserve was a ban on land use in areas with the region's most fertile soil. ${ }^{98}$

In March of 1985, the JACs, the Colonization Committee, and the political representatives of the FARC's 14th and 15th fronts, with the assistance of INCORA, presented the National Plan of Middle and Lower Caguán and Sunciya directly to President Betancur. The cornerstone of the plan was to undermine illicit cultivation through national government and departmental support for credit programs, road construction, schools, health clinics and the establishment of channels for marketing agricultural products. All this would lay the groundwork for socioeconomic development, making legal crops and ranching profitable enough to replace the income levels and living standards generated by coca cultivation. ${ }^{99}$

\footnotetext{
${ }^{96}$ In addition to INCORA, other state institutions present in the region participated in the development plans; the National Natural Resources Institute (INDERENA), the National Learning Service (SENA), the Institute of Agricultural Marketing (INDEMA), and the Colombian Institute for Family Welfare (ICBF); Uribe 2002: 223.

${ }^{97}$ Uribe 2002: 224

${ }^{98}$ Ferro 2004

${ }^{99}$ Author interview with Graciela Uribe, November 7, 2011 in Bogotá, Colombia
} 
In September of 1985, President Betancur traveled to Cartagena del Chairé to meet with community leaders and the FARC. In response to the Plan for Development, President Betancur enthusiastically presented the community with his proposal for a policy of peace and rehabilitation in the region. The president promised to deliver agencies and government functionaries in order to build "a new model of relations between the state and the colonizing community" that would transform Caquetá into a 'Peace Laboratory.' ${ }^{100}$ What followed was a series of meetings in Florencia, Caquetá, during which various actors participated in laying out the specifics of the plan:

We met in Florencia, in a meeting of Incora. In that meeting even the miltary participated. One could find the Brigade Commander, the Batallion Commander, without any problem. There was [FARC commanders] Iván Márquez, Joaquín Gómez and other [FARC] delegates that were sent ... At that moment they participated without fear, or any problem. In the year '86 we presented a project to the National Planning Department for almost $\$ 10,000$ million pesos in order to carry out the substitution of coca cultivation in the municipality of Cartagena del Chairá ${ }^{101}$

However in late 1986 the peace process between the government and the FARC collapsed and the development plan was abandoned. Incoming Colombian President Virgilio Barco (1986-1990) and the new departmental mayor, Cornelio Trujillo Penagos, together deauthorized and delegitimated the participation of the Colonization Committee and the Research Committee in the development and peace plans because of their links to the FARC. Rather than a 'Laboratory of Peace,' El Caguán was abandoned and became a true 'Laboratory of Subversion.' Indeed, the region was left to the near total control of

\footnotetext{
100 Jaramillo, et al. 1989: 199

${ }^{101}$ Testimony of community leader from Cartagena del Chairá that participated in the 1985 meetings in Florencia, Caquetá to discuss the development plans; Uribe 2002: 224
} 
the FARC. The government in Bogotá justified the policy of abandonment, arguing that the population was part of the guerilla movement as evidenced by their subversive involvement in illicit cultivation. It was, in essence, the 'Black Legending of El Caguán.'102

In June of 1986, it was clear that the national government would not deliver on any promises to assist in the economic restructuring of the region. The community began to voice concern. In 1986, an Agrarian Assembly was held in the town of Romolino del Caguán during which community leaders expressed how upset they were, criticizing the failure of the departmental government to finance the pacification and development initiatives, as well as government abandonment of the education and health of the community. Ironically, a major motivation for the community to make the plan and engage the government was to overcome the high political costs of coca. The local communities did not want to be politically isolated from the rest of the country. They were also troubled by the constant military operations that were devastating the regional economy. The community attempted to overcome their political isolation by engaging the government in an eradication effort centered on development. What they got was political abandonment and military repression. ${ }^{103}$

We at all times thought that the coca crops were illicit and that sooner or later the government had to do something. But the government itself did nothing. There was no policy to direct us that said 'don't cultivate coca.' ... [T] here was pressure on the part of some factions so that that money did not arrive to El Caguán. Because according to them, the guerilla was in el Caguán and the population of el Caguán

\footnotetext{
${ }^{102}$ Author interview with Graciela Uribe, November 7, 2011 in Bogotá, Colombia; author interview with Kyle Johnson, Research associate at Corporación Arco Iris, September 28, 2011 in Bogotá, Colombia; Jaramillo, et al. 1989: 94, 215

${ }^{103}$ Ferro 2004; Jaramillo, et al. 1989: 155, 202
} 
was a guerilla population. ... We presented the Project to the Department of National Planning so that they would study it and find the resources from wherever. ... I believe they obtained the resources, I don't know from what country, but they sent some big resources... [but] they rerouted the resources and they went to the Bota Caucana. I don't know if those who provided the money were from the United States or the European countries. The only thing I know is that it was a sad failure. ${ }^{104}$

Following the abandonment of the development plan, the military was sent to Caquetá. The increased militarization of the areas surrounding El Caguán meant roadblocks for those passing in and out of the zone. There were also battles between the military and the FARC that often resulted in civilian deaths and injuries. In addition, after the development plan failed the region was affected by a wave of crime including a number of killings. In response, the Colonization Committee and JAC leaders pleaded with the government, once again, to remedy the situation. ${ }^{105}$

In 1987, President Virgilio Barco sent representatives to the region, where they met with 5,000 peasant farmers in the Plaza de la Paz (Peace Plaza). There, the population presented the government with a list of grievances which included concerns over the militarization of the region, and the military's failure to distinguish civilians from insurgents in launching counterinsurgent attacks. The community presented the president with a Rehabilitation Plan that was remarkably similar to the Development Plan presented to President Betancur in 1985. During the visit, the Presidential Council, the National Secretary of Popular Integration and departmental government delegates met

\footnotetext{
${ }^{104}$ Juan Guillermo Ferro interview with a colono from north Caquetá, Colombia, 1999; Ferro 2004

${ }^{105}$ Jaramillo, et al. 1989: 216
} 
with the military commanders of the $14^{\text {th }}$ and $15^{\text {th }}$ fronts of the FARC, Jorge Briceño and Avelino Ul Medina, and all parties agreed to a truce in El Caguán. ${ }^{106}$

However, the local commander of the XII Military Brigade was skeptical of the truce, and he continued a military advance in the region into the lower Caguán including part of the central municipality of Cartagena del Chairá. In response, the FARC ambushed a military convoy, resulting in the deaths of 27 soldiers and another 40 injured. Following the attack, the government declared the end of the truce. In June of 1987, at a meeting of the Council for the Department of Rehabilitation in Bogotá, the Colombian government excluded Caquetá from the programs of the National Plan of Rehabilitation, a plan through which development aid reached parts of the national territory. This marked the complete political isolation of the zone of El Caguán on the part of the Colombian state. ${ }^{107}$

The abandonment was merely political. The military remained active in Caquetá though with little access to regions such as El Caguán where most coca cultivation took place. Nonetheless, the military encircled the FARC's stronghold. In 1988, the military operation Alfa Justiciero marked the beginning of a decade-long military presence in Caquetá. The military's mission in the zone was to combat the FARC, and also to carry out tasks associated with the forced eradication of coca. Hence, in contrast to Arauca where the military mission was protection of resources and economic actors, in Caquetá

\footnotetext{
106 ibid: $216-217$

107 The colonos continued to demand government programs to substitute coca cultivation. Sometimes the agricultural ministry would propose programs such as 'Operación Maíz' to replace illicit crops, but the substitution programs were poorly implemented and notoriously underfunded; Jaramillo, et al. 1989: 218219; also see Uribe 2005; Uribe and Ferro 2002.
} 
the military mission was to undermine the order created by the guerillas including the illicit economy on which that order was built. ${ }^{108}$

As part of the political abandonment, the state withdrew support for public services for health, education, water treatment, and infrastructure, arguing that the cause was declining security conditions. First, by 1986, there was almost a complete absence of state-funded health services in rural Caquetá. The health clinics, which had never had sufficient doctors or equipment to begin with, were then only occasional staffed by one or two private health care professionals. In 1986 there was one health center in Cartagena with eight beds, one doctor, one dentist, and five nurses. To make matters worse, that same year the national government ordered the Caquetá Malaria Service to suspend services in the zone due to the security situation. At the time, Caquetá registered one of the highest rates of malaria in Colombia. ${ }^{109}$

Second, in 1986 there was no sewage or water treatment in rural Caquetá. Lack of clean water contributed to a public health emergency because the communities were consuming water from the same river where they disposed of the chemicals and gasoline used to process coca, not to mention human waste. The state did not rush to resolve the problem. As of 1998, twenty years after the first coca bonanza began, only 148 homes in the capital city of San Vicente del Caguán with a population of 42,515 had access to

\footnotetext{
${ }^{108}$ Uribe 2002

${ }^{109}$ Author interview with Graciela Uribe, November 7, 2011 in Bogotá, Colombia; Jaramillo, et al. 1989: 66
} 
energy, running water, and sewage. At the same time, 4,462 homes in Caquetá's most populated urban center continued to be without access to any of these basic services. ${ }^{110}$

Third, the national government stopped providing funds to build schools and pay teachers in Caquetá. In 1986, there were only forty-five schools in the lower Caguán region with 30,000 inhabitants, and only one of those schools was a secondary school. Of the region's thirty seven neighborhoods, 44 per cent did not have any local schools in 1986. The schools that did operate in the region were the result of the direct participation of the community, and the teachers were appointed and paid by the local Community Action Board. A 1984 study by INCORA recorded an illiteracy rate of 31.68 per cent in El Caguán, Caquetá. ${ }^{111}$

Finally, more than a decade after the first coca seed was planted in Caquetá, the state failed to address the most critical obstacle to the development of licit agriculture in Caquetá; roads and communication infrastructure. As of 1989 only one land route, the Florencia-Rionegro highway, linked the regional market in Florencia, Caquetá, to the town of Doncello, 75 kilometers away in El Caguán. Without roads and transportation infrastructure, the communities remained dependent on coca as the only means to economic security. ${ }^{112}$

Besides schools and roads, the national government also failed to provide security for the communities of Caquetá. Military incursions were frequent in the parts of the department with coca, but security and justice spending in Caquetá and other coca-

\footnotetext{
${ }^{110}$ Cambio 16, November 2, 1998: 24

${ }^{111}$ Pedro Umaña et al., Aspectos Socioeconómicos del Bajo y Medio Caguán, Incora, Florencia. 1984, p. 6

112 Jaramillo, et al. 1989: 165-167
} 
producing departments was much lower than the national average. While the state sent its military apparatus to reclaim territory, there was less effort to secure a permanent military presence to provide security for local populations. What is more, while state presence certainly increased in coca-producing regions as it did in all frontier departments particularly during the 1990s, by 2005 the presence of the state was notably lower than in coca regions compared to oil-producing regions despite similar starting points. ${ }^{113}$

Table 5.7, State Capacity Gains in Oil and Coca Departments of Colombia, $2005^{114}$

\begin{tabular}{|c|l|l|l|l|c|}
\hline Indicator & Arauca & Casanare & Caquetá & Putumayo & Guaviare \\
\hline $\begin{array}{c}\text { Avg. Years of Schooling } \\
(1993-2005)\end{array}$ & 7.0 & 6.7 & 6.1 & N/A & N/A \\
\hline $\begin{array}{c}\text { \% Population Enrolled in } \\
\text { Social Security (1996-2005) }\end{array}$ & 70 & 95.6 & 54.7 & 65 & 58.2 \\
\hline $\begin{array}{c}\% \text { Homes with Water } \\
(1993-2005)\end{array}$ & 78 & 65 & 62.7 & 39 & 32.4 \\
\hline $\begin{array}{c}\% \text { Homes with Sewage } \\
(1993-2005)\end{array}$ & 70 & 58 & 54.7 & N/A & 33.4 \\
\hline Poverty (\%) (1993-2005) & 35.5 & 35.5 & 41.5 & 34.5 & N/A \\
\hline
\end{tabular}

In sum, Colombian government abandonment of Caquetá after 1986 coincided with two events that critically shaped the repressive policies that followed. First, the FARC walked away from peace negotiations with President Belisario Betancur at a time when the insurgency was becoming more threatening due to the coca economy. Second, the United States launched the supply-side policies of the 'War on Drugs' in 1986 with the Decertification Process. This process pressured the Colombian government to respond to the illicit drug problem with force. After 1986 the Colombian government,

\footnotetext{
${ }^{113}$ Holmes and Gutiérrez de Piñeres 2012: 113, 118

114 ibid
} 
with the support of the United States, began targeting the illicit producers of the Western Amazon and the llanos frontier with a policy of forced eradication of illicit coca.

\section{State Repression: Forced Eradication of Illicit Crops}

"Being defined as a colono (settler) and/or a cocalero (coca grower) became an exclusive category. It meant not only to be considered as migrants with no regional identity and/or delinquents, but also to be pinpointed as people to whom the central state does not ascribe a place within society and as such, can be objects of state violence. ${ }^{115}$

The foundation of the Colombian government's security policy for dealing with illicit drug production has been forced eradication of illicit crops. The policy has been carried out by a special division of the national police called the Colombian Antinarcotics police with financial assistance and sometimes direct participation of the United States. Indeed, Colombia has been the main focus of U.S. support for forced eradication since 1978. Forced eradication in Colombia takes two forms: manual eradication on the ground and aerial fumigation, or the spreading of chemicals and herbicides by plane to kill the illicit crops. Wherever possible, eradication is carried out by aerial spraying due to the security risks of having anti-narcotics police on the ground. The chemicals used have varied and include paraquat, triclopyr, and tebuthiuron. However, since 1986, glyphosate, a common herbicide, has been the chemical of choice for destroying illicit drug crops in Colombia. ${ }^{116}$

Chemical spraying in illicit crop zones has had serious consequences for the health and environment of the local inhabitants. What is more, glyphosate spraying threatens the livelihoods of thousands of peasants who may or may not cultivate coca.

\footnotetext{
115 Ramírez 2003

116 Vargas 2002: 12
} 
Glyphosate does not discriminate between coca and legal crops, including basic foodstuffs produced for family consumption. In addition, spraying with glyphosates has caused displacement in many Amazonian communities. As a result, community organizations have found it difficult to organize local efforts to develop alternative development projects to supplant coca. Alternative development has also been undermined more directly when glyphosate spraying destroys the licit crops cultivated as part of the program.

For all of the above reasons, forced eradication as a security policy weakened state legitimacy in areas where illicit crops were grown. As a result of the policy, illicit cultivators allied with insurgents as an alternative authority with organizational capacity to deliver some economic and military security. ${ }^{117}$ Morgane Landel argues that the impact on the health of the affected communities means aerial fumigation with glyphosates is a violation of the rules of international humanitarian law because it violates the 'health, physical and mental well-being of people' and also because it directly targets populations that are not direct participants in conflict hostilities. ${ }^{118}$

The Colombian government began forced eradication of illicit coca crops in 1986. Most of the forced eradication between 1986 and 1992 was done on the ground. However, because of security risks, and to reach a larger area, the use of glyphosate spraying was central to the security policies of Presidents César Gaviria (1990-1994) and Ernesto Samper (1994-1998). In 1994, the Colombian Anti-Narcotics Police declared it their mission to destroy all areas of illicit crops within two years. President Gaviria

${ }^{117}$ Felbab-Brown 2009

${ }^{118}$ Landel 2010 
(1990-1994) framed the forced eradication policies as critical to a broader 'Strategy to Overcome Violence.' Implicit in the government's approach was the criminalization of illicit producers who were seen as a threat to public order and a source of violence. The policy discourse hardly acknowledged the economic and social conditions that contributed to illicit cultivation in Colombia. The criminalization of coca growers resulted in an initial refusal to take alternative development programs seriously. ${ }^{119}$ As Vargas explains:

President Gaviria vehemently defended Washington's recommendations, going so far as to identify the production of illicit raw materials with drug trafficking itself. Therefore, areas in which illicit crops were produced were indiscriminately incorporated into the government's strategy for overcoming violence. Criminalizing images of the phenomenon were added to this, which contributed to completely effacing the economic or social roots behind the Andean region's illegal economy. In this sense, the decision taken in January 1992 to fumigate illegal crops was virtually a declaration of war against the communities growing these crops. ${ }^{120}$

Between 1992 and 1998, the Colombian Anti-Narcotics police sprayed 2,438,336 liters of glyphosate over about 46,400 hectares of illicit crops. The total cost of the spraying came to US\$53,211,497. At that time the state was combating the illicit cultivation of both coca and opium poppy. ${ }^{121}$ Of that cost, $\$ 24,487,783$ was spent on herbicide and $\$ 28,724,714$ was spent on the operation itself (aircrafts, anti-narcotics bases and interdiction infrastructure). The cost to Colombia was in addition to foreign assistance. The U.S. Departments of State and Defense reported that between 1990 and 1998 , US\$625 million worth of equipment was supplied to the Colombian national police

\footnotetext{
${ }^{119}$ Vargas 2002: 17-18, 25; also see Felbab-Brown 2009

${ }^{120}$ Vargas 2002: 18

${ }^{121}$ During the 1990 s, illicit cultivation of opium poppy to make heroin increased substantially in Colombia.
} 
and armed forces, including helicopters, weapons, aircraft, and training, with the specific purpose of carrying out aerial fumigation of illicit drug crops. ${ }^{122}$

Prior to 1998, most aerial spraying with glyphosates was undertaken in the departments of Caquetá and neighboring Guaviare where most illicit cultivation took place. ${ }^{123}$ Since that time, illicit fields have moved to new areas, largely as a result of displacement caused by the spraying. As illicit cultivation spread, the area targeted by glyphosate spraying grew larger. Table 5.8 shows the distribution of coca and fumigation efforts between 1994 and 1998. The table indicates that the area fumigated was often larger than the area of initial illicit cultivation, which means that fumigation coincided with increased coca cultivation through a process of displacement.

Table 5.8, Coca Area and Fumigation Area Colombian Departments, 1994-1998 ${ }^{124}$

\begin{tabular}{|c|c|c|}
\hline Department & Area of coca (ha.) 1994 & Fumigation Area (94-98) \\
\hline Guaviare & 26,300 & 95,362 \\
\hline Meta & 900 & 16,451 \\
\hline Caquetá & 23,993 & 11,700 \\
\hline Putumayo & 5,000 & 3,311 \\
\hline Vichada & 432 & 400 \\
\hline Vaupes & 1,250 & 349 \\
\hline Antioquia & 0 & 960 \\
\hline
\end{tabular}

Between 1998 and 2000 forced eradication of illicit crops in Colombia by way of aerial spraying decreased substantially due to President Andrés Pastrana’s (1998-2002) efforts to engage the FARC in peace talks. However, when the peace talks failed, forced eradication of illicit crops resumed and in fact increased under the U.S.-backed Plan

\footnotetext{
122 Vargas 2002: 14

123 ibid: 25

124 ibid: 26; data from the Colombian Antinarcotics Police
} 
Colombia which was proposed in September of 1999 and officially launched in 2000. Plan Colombia had two objectives. The first was to reduce the production and trafficking of illicit drugs in Colombia by 50 per cent in six years. The second was to improve security by reclaiming territories controlled by insurgents. The United States was the primary funding source for Plan Colombia which called for a large increase in aerial spraying with glyphosates. ${ }^{125}$

Between 2000 and 2008 the United States spent US\$458 million per year on drug eradication efforts in Colombia. This money went directly to the Colombian armed forces. Meanwhile, the Colombian government spent an additional US\$712 million per year. The cost of Plan Colombia made it the largest drug intervention program to be implemented in a producer country. ${ }^{126}$ As of 1999 there was an estimated 122,500 hectares of illicit coca cultivation in Colombia. In the first year, 43,426 hectares were sprayed as part of Plan Colombia. However, by 2007 the area sprayed with glyphosate had increased to 153,133 hectares. Again, the evidence suggests that spraying caused displacement of coca, but did not lead to a real reduction in the amount of coca leaf being produced. ${ }^{127}$ As long as there was demand for cocaine and heroin in the consumer countries, and a lack of viable legal alternatives, peasant populations continued to produce illicit crops to feed that demand.

Forced eradication of illicit coca and especially aerial fumigation with glyphosates had a number of negative consequences for the communities that inhabited

${ }^{125}$ Fukumi 2008: 177-214

${ }^{126}$ Mejía 2012: 20; Landel 2010: 492

${ }^{127}$ Landel 2010: 492; Fukumi 2008: 177-214 
the coca cultivation zones. Three outcomes increased the insecurity of coca-producing communities, and therefore directly contributed to a de-legitimization of the state vis-àvis the population. First, fumigation killed both illegal and legal crops, thereby threatening the economic security of inhabitants of the area. Second, fumigation had devastating environmental consequences that threatened the health of communities. Some of the environmental damage was a result of glyphosate, but much more was caused by populations fleeing and clearing new areas for cultivation. Third, fumigation caused displacement and the breakdown of communities. It pushed settlers further into the periphery and undermined local (non-state) efforts to develop legal alternatives to coca. Let us examine these outcomes in greater detail.

Forced eradication directly threatened the economic security and well-being of the communities that inhabited the areas targeted by Colombia's Anti-Narcotics Police. Aerial spraying destroys both licit and illicit crops. Without any viable alternatives, the peasants that cultivated coca did so out of economic necessity. But even where peasants were not cultivating illicit crops or were attempting to develop alternatives, their efforts were undermined by glyphosate spraying. Aerial fumigation was linked to declining fish populations and death and illness in domestic animals. According to one NGO, government spraying damaged some organically-certified farms in the Amazon region, causing the farmers to lose their organic certifications and subsequently their livelihoods. ${ }^{128}$

${ }^{128}$ Landel 2010: 502 
Aerial spraying in the el Caguán region of Caquetá between April and November of 1998 affected rubber plantations, and destroyed cacao crops, fruit trees, and subsistence crops. The destroyed rubber and cocoa plants were part of a local alternative development program by the San Isidro Parish in Remolino del Caguán. About 42 families participating in the San Isidro project lost crops that they had been cultivating for two to six years. Indeed, one of the most deleterious effects of glyphosate spraying has been the destruction of a handful of local projects aimed at developing licit alternatives. The chemicals destroyed the alternative crops, and the displacement that followed further undermined the projects by dissolving the community organizations that led them. ${ }^{129}$ In this way, the Colombian state became not just a neglectful authority, but an outright predatory authority in the region.

Second, local populations perceived that glyphosate spraying had a direct negative effect on their health beyond the damage to food supplies and economic production. Whether or not aerial spraying does in fact cause harm to human health is a contested question. A thorough but controversial assessment of the effects of glyphosate on human health carried out by the Organization of American States (OAS) found a very minimal direct effect. ${ }^{130}$ However, there is indeed significant and irrefutable evidence that aerial spraying pollutes water supplies and land as a result of chemical drift. In Colombia, fumigation planes spray glyphosate at altitudes above 10 meters in order to avoid attacks by insurgents. The planes are not able to control the fall of glyphosate and as a result the spray has at times extended across waterways, forests and population

\footnotetext{
${ }^{129}$ Vargas 2002: 31-32

${ }^{130}$ Solomon, et al. 2005
} 
centers. ${ }^{131}$ The glyphosate subsequently contaminates soil, air, water and food sources. ${ }^{132}$ Environmental assessments show that in El Caguán, Caquetá, aerial fumigation of coca fields killed fodder, and contaminated water supplies including lakes and wetlands. ${ }^{133}$

While the precise impact of glyphosate spraying on human health is difficult to assess, affected communities have sought recourse and have been supported by powerful international actors. The World Health Organization (WHO) found the evidence sufficient for concern, and urged that persons on the ground wear masks and be relocated away from the dropping zone during the spraying. No such precautions were taken. The WHO cited proof that glyphosate is poisonous if ingested and can cause diarrhea and vomiting along with skin and eye irritation. A study carried out in Ecuador found credible evidence that drift from aerial spraying across the border in Colombia had damaged the physical and mental health of Ecuadorians. Further, a 2005 study found that glyphosate was toxic to human placenta cells and could cause reproductive problems. Finally, NGOs and health care professionals working in the sprayed areas report deaths and illnesses consistent with glyphosate poisoning, though it is hard to disaggregate the effects of spraying from those of fertilizers and pesticides used in coca production. ${ }^{134}$

Nonetheless, the communities affected by glyphosate spraying have sought recourse through the Colombian court system. In a 2003 class action hearing, an Administrative Court in Cundinamarca, Colombia, ordered the Colombian government to stop aerial spraying in order to assess the health risks. However, the order was overturned

\footnotetext{
${ }^{131}$ Vargas 2002: 31-32

${ }^{132}$ Landel 2010: 502

${ }^{133}$ Vargas 2002: 31

${ }^{134}$ Landel 2010: 502
} 
by an Appellate Court based on the argument that coca is a threat to security, and the Colombian government has the right if not the obligation to address that threat. ${ }^{135}$

Even disregarding any effect on human health that glyphosate might have, the policy of forced eradication through aerial spraying has caused the area of cultivation to spread and intrude on protected rainforests with fragile ecosystems, producing a tremendous environmental impact. Indeed, most of the environmental damage from glyphosate spraying has resulted from the population displacement that it causes. ${ }^{136}$ Coca production did not decline in absolute terms due to aerial spraying, but the spraying did lead to new cultivations in more hidden spaces such as protected rainforest areas.

To plant new coca fields, peasant farmers cleared protected Amazonian rainforest with slash-and-burn techniques, resulting in severe deforestation. Between 2000 and 2007 about 158,000 hectares of rainforest were cut down in order to open up new coca farms. ${ }^{137}$ After clearing the forest, the farmers used chemical fertilizers and pesticides which are harmful to the surrounding ecosystem. Finally, processing coca leaf into coca paste is done using harmful chemical components such as cement, gasoline, and acetone. These chemicals pollute lakes and rivers and further threaten ecosystems as well as the health of local populations that use the water. ${ }^{138}$

The displacement of populations due to glyphosate spraying was not an accidental outcome of forced eradication. In fact, the state explicitly provoked displacement of frontier settlers that cultivated coca back to their places of origin in the more integrated

\footnotetext{
135 ibid: 501

${ }^{136}$ Brain and Solomon 2009

${ }^{137}$ Landel 2010: 503

${ }^{138}$ Mejía 2012: 21; Vargas 2002: 27
} 
regions of the country. In 1992 when fumigation began to increase, Police General Rosso

José Serrano expressed the State's position:

The intention of the police is to discourage the settlers planting these cropswho will be forced to return to their places of origin when their crops are destroyed-especially in the South of Huila and Caquetá, so that they will then return to legitimate activities. ${ }^{139}$

However, the displaced did not return to their places of origin to plant legal crops but instead settled new zones even further from the state where they planted more illicit crops. This explains the rise in coca cultivation in departments such as Putumayo and Nariño as crop eradication proceeded in Gauviare and Caquetá. ${ }^{140}$ In other cases the coca producers remained in the area and replanted. Particularly in zones with a strong insurgent presence, coca producers were able to politically organize in opposition to forced eradication. Indeed, the Colombian cocalero movement proved to be a powerful force against government policy. The cocaleros sought inclusion and government recognition of the social and economic marginality that was the real cause of coca cultivation. They sought assistance for alternative development in lieu of aerial spraying. Hence, at the same time that aerial spraying destroyed communities through displacement, it contributed to the formation of a coca grower or cocalero identity in opposition to the state but with strong links to insurgents. ${ }^{141}$

In many cases, the state responded to communites organizing and especially the cocalero movement with force. The use of military force against peasant organizations

\footnotetext{
${ }^{139}$ Vargas 2002: 19

${ }^{140}$ See Felbab-Brown, Vanda (2011) Coca and Insecurity in Nariño Colombia, Brookings Institute Foreign Policy trip report 20, retrieved online: http://www.brookings.edu/research/opinions/2011/02/22-colombiaguerrilla-felbabbrown

${ }^{141}$ Ramírez 2003, 2011
} 
was nothing new. Indeed, state repression was a major contributing factor in the weakening of community organizations in Caquetá as far back as the late 1970s. Then, state repression contributed to the dissolution of peasant organizations, the elimination of labor organization, and the weakening of unions. ${ }^{142}$ In 1996, the Colombian government again resorted to military force and roadblocks to subdue cocalero protestors, though with much less success as indicated by widespread participation of peasants in protest activities. Some 200,000 peasants marched in demonstrations across the Amazon and llanos regions that year. ${ }^{143}$

\section{Conclusion}

Although Colombia is not a traditional source of coca, illicit production of coca in Colombia increased substantially between 1978 and 2004. In response to illicit cultivation, the Colombian government has implemented policies that marginalize the peasant communities that produce coca, and repress their economic activities through forced eradication of illicit crops. In Colombia, the state has been consistent in repressing coca production despite numerous attempts by coca producers to engage the government in more development-oriented solutions that would replace coca with licit alternatives. The Colombian government's preference for eradication is premised on the link between illicit production and the military strength of insurgents, the inability of the state to exploit and regulate illicit production, and pressure from the United States, including economic sanctions for non-compliance with drug war policies.

\footnotetext{
${ }^{142}$ Uribe 2002: 215

${ }^{143}$ Ramírez 2003, 2011
} 
If measured by the stated goals of eliminating drug production in the Andean region, the policy of forced eradication in Colombia has failed. Between 1990 and 1998 the Colombian government spent more than US $\$ 41,405,840$ on eradicating illicit coca, yet the total area of coca cultivation tripled during the period. ${ }^{144}$ Forced eradication did not interrupt the illegal crop cycle, it simply displaced and spread the problem. As a result of Plan Colombia, there was an initial reduction in illicit cultivation in Colombia between 2000 and 2003. However, after 2003 production was steady, and the amount of trafficking remained steady throughout the entire period.

In response to eradication, coca cultivating peasants simply moved to new regions, cleared new lands, and replanted. ${ }^{145}$ Displacement spread the environmental damage caused by slash and burn techniques, chemical precursors. and fertilizers used to cultivate illicit crops. Displacement also undermined community efforts to implement alternative crop programs as grassroots efforts to undermine incentives for participating in the illicit economy. More recently, eradication campaigns in Colombia pushed coca production back across the border into Peru where aerial spraying is not possible due to the steep mountain topography surrounding the Upper Huallaga Valley. ${ }^{146}$

Beyond failing to meet the stated goals, government neglect and forced eradication in coca-producing areas such as Caquetá has been counterproductive to the war effort in Colombia. By criminalizing and targeting illicit cultivators, the Colombian state created a legitimacy crisis for itself vis-à-vis the populations that produce coca. The

\footnotetext{
${ }^{144}$ Vargas 2002:14

${ }^{145}$ Mejía 2012: 21

${ }^{146}$ Mejía 2012: 21-22, 24; Vargas 2002
} 
state failed to deliver public goods and worse, undermined local efforts to do so. Vargas explains:

Instead of representing collective interests, the state simply becomes one more stakeholder, behaving like any other private stakeholder and using its political clout to its advantage. This affects the very nature of the state as enforcer of the rule of law and as an organizational order orienting society's multiple interests. ${ }^{147}$

Hence, from the perspective of illicit coca producers, the Colombian state was the cause of economic insecurity and disorder in their communities. Caquetá, Colombia, is one of many areas where the population turned to the FARC, an armed insurgent organization with the capacity to defend their interests and overcome collective action problems in response to state neglect repression. For their part, the FARC was threatened by the wave of crime and community dissolution caused by the coca boom and would also benefit from regulating the illicit crop, as well as accessing illicit resources to support war activities. Hence, government policies created a space in which the economic and political interests of insurgents and civilians conjoined. Over time, the FARC supplanted the state as the legitimate authority in coca-growing regions such as Caquetá.

147 Vargas 200232 


\section{Chapter Six The FARC and Legitimate Authority}

The war tactics surrounding aerial spraying, expressed in operational guidelines and statutes typical of an armed conflict, violate the basic rights of communities. This has repercussions for the political and military goals of the insurgency and helps foster a certain legitimacy among those who have taken up arms in a great part of the national territory. ${ }^{l}$

[T] he exercise of parallel government functions by the FARC in certain coca growing areas has had important political consequences... [T] he opposition of the FARC to the Colombian government's campaigns to stamp out illicit crops has been doubly motivated. On the one hand, the insurgents have tried to defend their drug-based revenues, while at the same time trying to protect the interests of the coca growers with the aim of ensuring their continued political support for the rebel movement. ${ }^{2}$

This chapter looks at the Revolutionary Armed Forces of Colombia (FARC), a leftist insurgent organization, and their interactions with the communities that cultivate coca in the Amazonian department of Caquetá, Colombia. I provide empirical evidence that the illegal economy of coca supported the FARC not only with riches, but also the economic foundations to build a powerful coalition with an excluded community. The illicitness of coca created a mass of 'illegalized' actors that stood to benefit as the social base of the insurgency. ${ }^{3}$ The result was legitimate insurgent authority, or authority based on popular consent.

Legitimate insurgent authority was not an inevitable outcome based on structural conditions. Rather, it came about because the state neglected and ultimately repressed the population of peasant illicit producers. At the outset, illicit producers sought government

\footnotetext{
${ }^{1}$ Vargas 2002: 33

${ }^{2}$ Ortíz 2002: 138

${ }^{3}$ Ferro and Uribe 2002
} 
support in eradicating coca. However the Colombian government politically abandoned the region, an act that pushed community interests into fusion with those of the insurgency. Once the FARC had established legitimate authority, state efforts to militarily conquer the Western Amazon were mired by strong ties between insurgents and civilians. The social order constructed by the FARC in Caquetá fell only after coca, and much of the population, were displaced from the region after 2004.

The empirical evidence presented here comes from two main sources: testimonies and regional ethnographies archived at the Center for Research and Popular Education (CINEP) in Bogotá, Colombia, and interviews with community leaders, non-government organizations, and academic experts with experience in Caquetá. ${ }^{4}$ The chapter begins with the origins of the FARC, and their occupation of Caquetá during the coca bonanza beginning in 1979. I then describe the FARC's cooperative economic strategy in Caquetá as a reaction to state repression. Without government support, peasant communities were dependent on an illegal economy with deleterious economic and social consequences. The FARC regulated the illicit economy and re-established order in exchange for rents. The population benefited from the provision of public goods, while the FARC used coca rents to build military capacity. The mutually beneficial exchange was the foundation for a rudimentary social order based on legitimate non-state authority.

\section{Antecedents: The FARC and Caquetá before Coca, 1964-1978}

\section{The Founding of the Revolutionary Armed Forces of Colombia (FARC)}

\footnotetext{
${ }^{4}$ Due to the security situation in Caquetá in the last months of 2011, I was unable to visit the zone.
} 
The Revolutionary Armed Forces of Colombia are by far the largest and most powerful non-state armed actor in the Colombian conflict and historically in the Latin American region. The FARC officially emerged as an insurgent organization in 1964 and is unique among Colombian armed groups for its rural character and almost exclusively peasant membership. Indeed, the FARC emerged from peasant self-defense movements during the La Violencia era (1948-1963). Over time, the FARC has incorporated some urban members, but even at the turn of the century, one FARC commander estimated that about 90 per cent of FARC members had peasant or indigenous origins. ${ }^{5}$ Finally, the FARC is unique for its remarkable military capacity during the last two decades of the twentieth century. ${ }^{6}$ FARC military capacity far surpassed that of all other non-state armed actors in Colombia. This in part has to do with the FARC's successful exploitation of the illicit drug trade.

The FARC evolved from a group of loosely networked Communist and Liberal peasant self-defense groups in the 1950s. During the period of civil war known as $L a$ Violencia (1948-1963), violence began in the capital city of Bogotá, but then spread to the countryside. The Liberal party elite resisted Conservative forces in rural areas by organizing the peasant population into guerilla bands or self-defense groups. ${ }^{7}$ The violence resulted in a military coup in 1953 and the installation of military dictator Gustavo Rojas Pinilla. In June of 1953, Rojas Pinilla offered amnesty to the Liberal guerilla bands in exchange for their demobilization. Many peasants laid down arms only

\footnotetext{
${ }^{5}$ As further evidence of the distinctly rural and peasant background of FARC members, only about 50 per cent of FARC commanders had completed primary school as of 1999; Ferro and Uribe 2002:64, 81.

${ }^{6}$ Currea-Lugo 2007: 106

${ }^{7}$ See Oquist 1981, and Sánchez and Meertens 1984
} 
to be targeted by state security forces or Conservative party bosses. A founding member of the FARC, Jacobo Arenas, describes how the pacification process under General Rojas Pinilla resulted in the peaceful demobilization of thousands of armed peasants who were later assassinated by the armed forces. As a result, some peasant self-defense groups remained in arms. In 1954, Rojas Pinilla ordered military incursions into the regions where armed groups were still active. Arenas reports that at that time there were approximately 800 peasants still in arms being pursued by ten thousand military soldiers. ${ }^{8}$ In response to the military threat, a group of Liberal peasant families including the Maríns, Loaizas, and Lasuro Yosas - founding leaders of the FARC - formed the National Revolutionary Army and established a 'free zone' which was essentially a peasant farming cooperative called El Davis in the department of Tolima. ${ }^{9}$ Among them was Pedro Antonio Marín, better known by his nombre de guerra Manuel Marulanda Valdéz (aka Tirofijo or 'sure-shot'), the infamous top commander of the FARC from 1964 until his death from a heart attack in 2008. El Davis was a model for similar farming projects in Marquetalia, Riochiquito, El Pato, and Guayabero. ${ }^{10}$ These communities, located in the central Andean departments of Caldas, Huila, Cundinamarca, and Tolima were contemptuously labeled 'Independent Republics' by the political elite in Bogotá. Indeed, the national government grew increasingly hostile toward the self-

\footnotetext{
${ }^{8}$ Arenas 1985:81

9 Tolima is located in the central Andean region. It is a coffee-growing department where Conservative and Liberal forces did a great deal of fighting during La Violencia; see Henderson 1985.

10 The history of the marquetalianos and the peasant republics in Marquetalia, Riochiquito, El Pato, and Guayabero is a source of constant motivation and even mysticism for the FARC used to engender solidarity; Ferro and Uribe 2002: 35.
} 
contained peasant communities and the peasants responded by organizing an armed defense. $^{11}$

With the signing of the National Front in 1957, democracy was restored in Colombia but in a way that institutionalized oligarchic power and excluded popular forces. ${ }^{12}$ The Front ended a decade of bloodshed with a power-sharing agreement between the dominant Liberal and Conservative parties that guaranteed a rotation of office. There was no incentive for either party to incorporate the popular sectors as an electoral strategy, which is essentially the process by which political participation was expanded in other Latin American countries. ${ }^{13}$ Indeed, the National Front governments (1958-1974) never resolved the social questions that ignited violence in the countryside, above all the issue of rural inequality and especially the concentration of land in the hands of a small rural elite. Hence, the independent republics were a rejection of the National Front due to political and economic exclusion. These were autonomous, insular societies built with the support of the excluded Colombian Communist Party (PCC) wherein land was communally worked and production communally owned. ${ }^{14}$

In the context of the Cold War, the Independent Republics were understood as a threat to the Colombian government and also to the United States. In 1958, President

\footnotetext{
${ }^{11}$ Ferro and Uribe 2002: 25-26, 28

12 The National Front alternated the presidency and political posts in Colombia between the Liberal and Conservative party every four years.

${ }^{13}$ Colombia did not have a period of populist government comparable to that of the nations of the Southern Cone, Peru and even Venezuela. Colombia is the only Latin American country to never implement a major agrarian reform. In Colombia, we find only incremental and largely ineffective efforts to deal with rural inequality.

${ }^{14}$ In Colombia the social question had two dimensions; the rural dimension which had to do with the unequal distribution of land and resources, and the urban question which had to do with extending political inclusion to the popular classes.
} 
Alberto Lleras Camargo ordered a series of military attacks on the independent republics based on a new doctrine of national security that embraced offensive 'preventative warfare' as a means to quash the fires of an emerging rebellion. On May 27, 1964, Conservative President Guillermo León Valencia, with support from the United States Plan LASO (Latin American Security Operation), ordered 'Operation Marquetalia,' a major military offensive on the largest peasant republic in Marquetalia, Tolima. ${ }^{15}$

Operation Marquetalia was a huge military success that drove the peasants out of southern Tolima. In the aftermath of the devastating attack, there were only 48 peasant leaders remaining. They fled to the jungles of the eastern and southern frontier, accompanied by many of the families that had settled in the peasant republics, which eventually all succumbed to military attacks. Colombian historians refer to the event as an 'armed colonization' of the Western Amazon and llanos frontiers. ${ }^{16}$ The guerilla leaders and their civilian followers settled in the departments of Guaviare, Meta, and Caquetá. There they found additional support among the peasant colonizers who had been displaced to the region by violence a decade earlier. ${ }^{17}$

The 48 peasant leaders that led the armed colonization in the aftermath of Marquetalia officially formed the Revolutionary Armed Forces of Colombia (FARC), a 'peasant army,' on July 20, $1964 .{ }^{18}$ Influenced by the Colombian Communist Party's (PCC) soviet faction, the political platform of the FARC centered on agrarian reform and

\footnotetext{
${ }^{15}$ The Colombian military reports that they sent 1,500 men ( 3 batallions) while the FARC claims about 16,000 soldiers attacked the community; Matta 1999:47-52; Arenas 1985: 82; Ferro and Uribe 2002: 28.

${ }^{16}$ The term 'armed colonization' was first coined in 1981 by William Ramírez Tobón.

${ }^{17}$ Arenas 1985: 81-84

${ }^{18}$ Arenas 1985: 92; Ferro and Uribe 2002:22
} 
rural development. During the first two decades of its existence, the FARC did not pose a serious threat to the government in Bogotá. In fact, the FARC survived only because the rough jungle terrain protected them. However, because they were limited to the most economically marginal regions, the nascent insurgency could not gather sufficient resources to expand. This was the case until the late 1970s when the first illicit crops appeared in Cartagena del Chairá in Caquetá, in Miraflores, Guaviare, and in La Macarena, Meta.

The departments of Guaviare, Meta, and Caquetá encompassed the geographic center and undisputed territorial stronghold of the FARC. In a desolate region, far from domestic and international markets, coca cultivation presented an extraordinary economic opportunity for peasants and insurgents alike. With access to coca rents, the FARC constructed a formidable military opponent with roughly 18,000 armed fighters and control over 40 percent of national territory.

Table 6.1, FARC Fronts and Fighters, 1964-1999 ${ }^{19}$

\begin{tabular}{|c|c|c|}
\hline Year & Fronts & Fighters \\
\hline 1964 & & 44 \\
\hline 1984 & 27 & \\
\hline 1986 & 32 & 3,600 \\
\hline 1989 & 44 & 13,200 \\
\hline 1995 & 60 & 7,000 \\
\hline 1999 & 60 & 18,000 \\
\hline
\end{tabular}

${ }^{19}$ Díaz and Sánchez 2004 


\section{The Bloque Sur in Caquetá}

In 1978, with the taking of the municipality of Cartagena del Chairá in the lower Caguán region, the FARC inaugurated its official presence in the department of Caquetá. ${ }^{20}$ At that time, the FARC was still a small army of about 1,000 armed combatants but with a clear hierarchical structure. The organization was divided into seven regional blocks, and then further divided into fronts and squads. ${ }^{21}$ The bloque sur (south block) was active in Caquetá. The bloque sur was created in 1966 at the FARC's second conference as part of an effort to expand the organization south into the Amazonian region. The lower Caguán region of Caquetá where coca cultivation was taking place was occupied by the $14^{\text {th }}$ and $15^{\text {th }}$ fronts of the bloque sur under the command of Avelino and Mono Jojoy. ${ }^{22}$ Other FARC commanders active in the zone include Iván Márquez, Joaquín Gómez, and Fabián (political commander). ${ }^{23}$

Table 6.2, Chronological Summary: The FARC in El Caguán ${ }^{24}$

\begin{tabular}{|l|l|}
\hline 1978 & Taking of Cartagena del Chairá \\
\hline $1978-1982$ & $\begin{array}{l}\text { Social transformation } \\
\text { Coca bonanza } \\
\text { Self-defense groups to re-establish order }\end{array}$ \\
\hline $1982-1986$ & $\begin{array}{l}\text { Negotiating with the State } \\
\text { Peace negotiations with government } \\
\text { Eradication of coca through development } \\
\text { Organization of colonos } \\
\text { Begin economic regulation }\end{array}$ \\
\hline $1987-1995$ & $\begin{array}{l}\text { Building Hegemony } \\
\text { Expand economic regulation } \\
\text { Expand political control } \\
\text { Military incursions by state }\end{array}$ \\
\hline
\end{tabular}

${ }^{20}$ Uribe 2002: 206

${ }^{21}$ Ferro and Uribe 2002: 29

${ }^{22}$ Uribe 2002: 208-213

23 ibid: 230

${ }^{24}$ ibid: 248 


\begin{tabular}{|l|l|}
\hline $1996-1999$ & FARC Hegemony \\
& Peasant cocalero marches \\
& Successful military actions \\
& Demilitarized zone \\
& Economic control \\
\hline
\end{tabular}

Between 1982 and 2004, the bloque sur transformed from a relatively weak local peasant rebellion into the FARC's most powerful regional block largely due to the development of a coca economy in the Western Amazon. In contrast to other regional blocks, the bloque sur did not depend on the material or voluntary support of the population, but instead supported its activities almost entirely with taxes levied on the illicit economy. Hence, like Domingo Laín in Arauca, the bloque sur exercised much greater autonomy vis-à-vis the rest of the FARC organization. The bloque sur was the protagonist of many successful military engagements with the army between 1996 and 1998. During that time, it is probable that the Caguán region alone produced enough wealth for the bloque sur to satisfy all its economic needs and generate a surplus for other fronts operating in regions without significant resources. ${ }^{25}$

Prior to coca, the bloque sur survived by forming strong ties with peasant colonos (colonizers) who had settled in the lower Caguán region including the municipalities of Cartagena del Chairá, Remolino, and Puerto Rico. Like Domingo Laín, the FARC gained the support of the peasant sector by organizing the interests of colonos vis-à-vis powerful regional interests. And just as Domingo Laín filled their ranks with local recruits, the FARC secured relations with colonos through recruitment. In Caquetá, the FARC

${ }^{25}$ Ferro 2004 
implemented 'la regla de las FARC' (the rule of the FARC) which required peasant households to send at least one family member as a recruit. The direct participation of family members in the FARC linked the insurgent organization to every household in the region and gave the FARC extensive social control as well as maximized information, knowledge of the area, and incentives for community cooperation with the guerillas. ${ }^{26}$ Knowledge of the local area later facilitated the FARC's control of illicit production since the insurgents knew who was cultivating coca and how much.

In Caquetá, the FARC depended on extortion payments called vacunas paid by agrarian elites in nearby regions. FARC 'protection rents' levied on a legal economic activity were called a vacuna or 'vaccine' because payment immunized the individual or organization from insurgent violence. The vacuna was an outright protection racket. In turn, protection rents levied on illegal economic activity are called a gramaje, or 'weight' because the tax is determined by the weight of the merchandise in kilograms. ${ }^{27}$ The gramaje is based on a mutually beneficial exchange of rents for protection from the state and in some cases the criminal organizations that controlled the illicit market. ${ }^{28}$

Before coca, the vacuna and to a lesser extent kidnapping were the main methods by which the FARC financed its activities. The insurgents mostly targeted wealthy landowners - though also some smallholders - in the piedmont region of Caquetá closer to the capital of San Vicente del el Caguán. Due to the greater proximity to regional markets, several profitable ranches were founded in San Vicente beginning in 1935 with

\footnotetext{
${ }^{26}$ Author interview with Kyle Johnson, research associate with Corporación Nuevo Arco Iris, September 28, 2011, in Bogotá, Colombia; also see Jaramillo, et al. 1989

${ }^{27}$ Currea-Lugo 2007: 106

${ }^{28}$ Uribe 2002
} 
the famous Hacienda Larandía, a 40,000 kilometer ranch that was one of the largest in Latin America. Local testimonies suggest relations between the FARC and rural elites were cooperative but tense. As one rancher describes it:

In Caquetá large landownership is not so pronounced as in other regions. The FARC charges a vacuna on ranchers and smallholders that have their little plot of land. Because of the expansion of the vacuna, kidnappings have decreased. I don't want to say that kidnapping doesn't happen in Caquetá, but I believe that the kidnapping rate is lower than the rest of the country. But in order to maintain this good relation with the FARC, one is doomed to pay the vacuna. ${ }^{29}$

The FARC's preference for the vacuna over kidnapping was based on the logic of not stirring rebellion and flight, since rural elites were more likely to resist the former. Indeed, kidnapping was the primary grievance that led to the formation of local paramilitary groups and death squads during the 1980s and 1990s. The paramilitaries succeeded in evicting the FARC in some areas in the early 1980s including parts of the Magdalena Medio and Córdoba. ${ }^{30}$ In places such as Puerto Boyacá, Colombia, FARC kidnappings and extortions took a toll on local landowners, businesses, and even the peasant sector. In the early 1980s, rural elites in Puerto Boyacá allied with narcotics traffickers to form a small army capable of ousting the FARC and their unarmed civilian supporters. Perhaps a similar outcome would have transpired in Caquetá had there not been coca. Indeed, some wealthy landowners left Caquetá when the FARC arrived. In

\footnotetext{
29 ibid: 217

${ }^{30}$ see Medina 1990
} 
2001, a resident testified that only one latufindista remained in San Vicente del Caguán, and he had to pay the vacuna to live freely. ${ }^{31}$

Therefore, illicit rents did not replace extortions but they did decrease FARC dependence on the vacuna and ransom kidnappings, allowing the FARC flexibility in negotiations with agrarian elites. However, this was only in zones with illicit cultivation. In other regions, extortion and kidnapping were the norm. Hence, as late as 2001 the FARC implemented Law 002, which said that individuals and organizations with profits of more than one million US dollars a year would pay the FARC a 10 per cent tax. ${ }^{32}$ Ironically, the FARC called the law a 'Peace Tax.' Top leader Manuel Marulanda Vélez explained, "It's a guerilla law to stop the kidnappings and other forced payments that we did and that created discomfort in our relations with the communities in our areas of influence." 33

And yet the so-called 'peace tax' was as coercive as the vacuna. In more economically integrated regions of the country including neighboring Meta and parts of northern Caquetá, the FARC extortion scheme was extensive. In the more metropolitan center of Villavicencio, Meta, there are several consumer malls, retailers, and factories owned by large multinationals such as Nike. These companies were subject to the FARC's peace tax. In 2011, the multinational company Nestle was engaged in dairy production in Caquetá and reported paying extortion rents to the FARC. When FARC demands were met, the companies went about their business. However, refusal to pay or

\footnotetext{
${ }^{31}$ Soto-Trillo 2001:102

${ }^{32}$ Currea-Lugo 2007: 113

${ }^{33}$ Lozano (2000) Las realidades ocultas del proceso de paz, in VOZ No. 2043, May 10-16, 2000
} 
collusion with state security forces resulted in violence that often forced companies and retailers to leave the area. ${ }^{34}$

\section{II: The FARC and Cooperative Rent-Seeking in Caquetá}

The FARC formed the strongest ties with those populations that cultivated coca in Caquetá, which were concentrated in the lower Caguán region. The national government's political abandonment of Caquetá after 1985 was particularly devastating in this region where there were no economically viable alternatives due to the difficulties of traveling even to San Vicente del Caguán. As it became clear that there would be no government assistance, popular pressure increased for the FARC to supplant the functions of the state in order to protect the colonos from the devastating effects of coca. At that time, the FARC remained in favor of eradicating coca, but nonetheless bargained due to the economic devastation caused by the recent drought. The FARC temporarily permitted illicit cultivation. However, in exchange the colonos had to accept certain regulations and to continue to pay the FARC a percentage of the profit. From this bargain a cooperative rent-seeking strategy emerged in which the FARC imposed law and order in exchange for the collection of fixed taxes and fees from cultivators, intermediaries, and even narcotics traffickers.

\footnotetext{
${ }^{34}$ On occasion, companies refused payment and became targets of FARC violence. For example, the oil multinational Mapiripan-Argentine Oil Company sought the protection of the Colombian military to avoid paying the FARC. FARC responded by downing two helicopters. The company later abandoned their operations in the zone. The military has uncovered FARC laptops with bank information and financial portfolios on individuals that frequent the Villavicencio-Bogotá highway where the FARC kidnaps travelers for ransom; Author interview with Kyle Johnson, Research association with the Corporación Nuevo Arco Iris, September 28, 2011, Bogotá, Colombia.
} 
Table 6.3, Chronology of FARC and the Illicit Economy in Caquetá, 1977-2001 ${ }^{35}$

\begin{tabular}{|c|l|}
\hline Year & \multicolumn{1}{c|}{ FARC Intervention } \\
\hline 1977 & Begin coca cultivation \\
\hline $1978-79$ & $\begin{array}{l}\text {-Initial opposition to coca } \\
\text {-Create 'self-defense' militias }\end{array}$ \\
\hline $1979-1999$ & $\begin{array}{l}\text { - Begin regulation of coca cultivation with requirement that } \\
\text { cultivators also plant subsistence crops }\end{array}$ \\
\hline $1982-1998$ & -Charge taxes on coca paste merchants, laboratories, and cargo flights \\
\hline 1985 & $\begin{array}{l}\text { Illicit crop substitution proposal included in the El Caguán } \\
\text { development plan between the FARC, the state and the community }\end{array}$ \\
\hline $1991-1992$ & $\begin{array}{l}\text { Policing regulation of narcotics traffickers and cocinas (processing } \\
\text { labs) }\end{array}$ \\
\hline $1998-1999$ & $\begin{array}{l}\text {-Restrict entry of coca buyers for fear of entry of paramilitaries } \\
\text {-Begin purchase competition from paramilitaries }\end{array}$ \\
\hline 1999 & $\begin{array}{l}\text { FARC proposes second illicit crop substitution plan to be carried out } \\
\text { in Cartagena del Chairá, Caquetá }\end{array}$ \\
\hline 2000 & FARC directs marketing of coca paste \\
\hline
\end{tabular}

\section{The Illicit Market and Local Demands for Public Goods}

Look, the initial request came directly from the community, like I told you initially they requested that they [the FARC] regulate and impose living standards that one would call 'humane' in the region, and the narco-traffickers themselves were those that requested that they [the FARC] provide vigilance so that they could make their shipments, to send coca to other places. ${ }^{36}$

Insurgent groups cannot maintain control over territory without the support of a local actor. For this reason, in both Arauca and Caquetá the ELN and the FARC shaped their economic strategies based on the demands of local populations. In Arauca, demands were distributive: the colonos wanted a greater share of the wealth and benefits of oil extraction. In Caquetá demands were for public goods: the colonos wanted economic

\footnotetext{
${ }^{35}$ Graciela Uribe 2002

${ }^{36}$ Juan Guillermo Ferro interview with local community leader in Cartagena del Chairá, Caquetá in 1999;

Ferro 2004
} 
security and order amid tremendous turmoil. In Arauca, demands were shaped by state policies that favored foreign investors' interests over those of the local communities. In Caquetá, demands were shaped by state policies that politically ostracized the region and its criminal economy.

The colonos of the lower Caguán began to pressure the FARC for protection because their efforts to resolve their problems with the government had failed. The FARC became the only local authority with enough organizational capacity to re-establish order and ensure protection. In response, the FARC developed rudimentary mechanisms for taxing coca, but remained in favor of eradicating the crop. Coca cultivation threatened revolutionary goals because it undermined the solidarity of the peasant communities which were the insurgents' primary source of support. Coca attracted a new population to the region, which presented difficulties for FARC social control. Finally, dependence on coca exposed the communities to devastating economic downturns coupled with the underproduction of basic food. ${ }^{37}$

Indeed, had it not been for a chance event, the FARC might have put an end to coca in Caquetá right away. That chance event was a drought. In 1979, Caquetá was afflicted by a serious drought and subsequently a food shortage and the loss of about 2,000 head of cattle and the evacuation of another 50,000 to San Vicente del Caguán where they were sold below value. ${ }^{38}$ According to one local, the community lost 15,000 square kilometers of forest due to drought fires. The deforestation caused a plague of worms known as

\footnotetext{
${ }^{37}$ Author Interview with Kyle Johnson, research associate with the Corporación Nuevo Arco Iris, September 28, 2011, Bogotá, Colombia

${ }^{38}$ Uribe 2002: 206; Ferro 2004
} 
medidores that destroyed 70 per cent of crops. Despite the hardship, the Agricultural Marketing Institute (IDEMA), the only state entity that purchased crops in the region, paid far below market value for corn that year. ${ }^{39}$

Because of the drought, the FARC suspended eradication plans. The insurgents allowed coca on the grounds that profits from coca be used to purchase imported food from other regions. ${ }^{40}$ In exchange, the FARC collected a percentage of coca profits to be used to strengthen the organization militarily. The original agreement was that coca cultivation would continue for a period of two years and then eradication would be resumed. ${ }^{41}$ In the two years that followed, Caquetá experienced a coca bonanza. A tremendous amount of capital entered the region practically overnight. The quiet frontier experienced a wave of violent crime. The community organizations could not maintain security.

In 1979, the FARC stepped in, creating quasi-civilian militias to monitor the cocagrowing communities. In essence, the FARC wanted to control the illicit economy while shielding their organization from criminal influences. The militias were outside the organizational hierarchy, which made it difficult for FARC leaders to control them. ${ }^{42}$ There were complaints of robberies, murders, and rape by militia members. ${ }^{43}$

\footnotetext{
${ }^{39}$ Juan Guillermo Ferro interview with a doctor and historian in Cartagena del Chairá, Caquetá in 1999 in Ferro 2004

${ }^{40}$ Author Interview with Kyle Johnson, research associate with the Corporación Nuevo Arco Iris, September 28, 2011, Bogotá, Colombia

${ }^{41}$ Ferro 2004

${ }^{42}$ Author Interview with Kyle Johnson, research associate with Corporación Nuevo Arco Iris, September 28, 2011, Bogotá, Colombia; Uribe 2004

${ }^{43}$ Puentes Marín 2006: 55; author interview with Kyle Johnson, researcher associate with Corporación Nuevo Arco Iris, September 28, 2011, Bogotá, Colombia; Uribe 2004
} 
Community leaders and coca merchants were assassinated by militias. ${ }^{44}$ The people protested. "We went various times to the [FARC] camps to question the muchachos and bring to their attention concrete examples, that instead of attracting bases of support through political consciousness, they were scaring us away, with an effect that was diametrically the opposite of what they wanted." 45 By 1980, the militias had been entirely dismantled by the FARC and many of their members were executed. ${ }^{46}$

Meanwhile, the community action boards (JACs) opened up a dialogue with the state to explore ways in which coca could be eradicated through economic development. During talks with President Betancur, the FARC once again established a ban on new coca cultivation, and even forcibly eradicated new plants. However, by 1985 the state had abandoned the development plans. Without government assistance, the community was dependent on illicit cultivation, which provided them with a subsistence even while it generated tremendous chaos and insecurity. In light of these circumstances, the colonos sought an amplified role for the FARC to substitute for the lack of the state, and to overcome the prevailing law of the strongest which made daily life extremely insecure. ${ }^{47}$

After abandoning the peace process, the state stepped up its military efforts to combat the FARC, leaving the insurgent organization in dire need of resources. Traditional methods of accessing rents, including extortion and kidnapping, proved dangerous in other FARC territories due to the violent reaction of some regional elites

\footnotetext{
${ }^{44}$ Uribe 2002: 221

45 ibid: $221-222$

${ }^{46}$ Juan Guillermo Ferro interview with community leader in Cartagena del Chairá in 1999; Ferro 2004

47 Author Interview with Kyle Johnson, research associate with the Corporación Nuevo Arco Iris, September 28, 2011, Bogotá, Colombia
} 
and the flight of others. ${ }^{48}$ Hence, the FARC consolidated their strategy in light of the failure to eradicate coca. The FARC ascertained that they could benefit from the drug trade while building social support.

\section{The Exchange: Public Goods for Taxation}

Between 1985 and 1995, they started to form an economic and policing presence that was manifested in the charging of taxes to the merchants of coca paste and in the imposition of rules of a disciplinary character on the population. ... Another type of presence is their work with community in executing works for the common good: village roads, highways, bridges, waste control, urban reorganization...the taxes that they charged people in the region were invested in the realization of these works. ${ }^{49}$

The FARC engaged in three activities in coca-growing regions that were the basis of a social pact with local communities: collecting taxes, exercising a regulatory function over the illicit economy, and serving as an 'interface' between illicit cultivators and narcotics traffickers. ${ }^{50}$ The decision to tax the illicit trade was made early on at their $7^{\text {th }}$ Conference in 1982. However, after 1985, the FARC's taxation policy was expanded to support a more direct rule for the FARC in the regulation of the illicit market and maintenance of order. As I show here, the decision to increase regulation and taxation was in large part a reaction to pressure from coca producers, and was initially understood by both the FARC and the communities as a temporary solution to economic hardship.

After peace talks between President Belisario Betancur and the FARC failed in 1985, the national government launched a military campaign against the insurgents.

\footnotetext{
48 The most prominent case was the paramilitary expulsion of the FARC from Puerto Boyacá, a region with strong leftist sympathies and support for insurgents in the Magdalena Medio region. The paramilitary group that ousted the FARC was a locally formed armed organization supported by large landholders and even part of the peasant sector; see Medina 1990

${ }^{49}$ Uribe 2002: 223

${ }^{50}$ Ferro and Uribe 2002: 11-12
} 
Suddenly, the FARC was in desperate need of resources, and the illicit trade was the most likely source. Hence, the FARC expanded their policy of taxing illicit cultivations to create a tax system with fixed fees on different actors. They continued to collect a gramaje (weight) of a fixed 7-10 per cent tax on the sale of coca leaf and paste paid by illicit cultivators. However, in addition to cultivators, the FARC extended the gramaje to narcotics traffickers and their merchant intermediaries. ${ }^{51}$ Merchants paid the FARC about 8 per cent on the purchase of coca leaf and paste, and narcotics traffickers paid fixed fees for protection of their laboratories, airports, and properties. ${ }^{52}$ Over time the FARC exempted peasant smallholders from the tax. However, large scale coca farmers and medium growers continued to pay. A coca farmer from Cartagena del Chairá describes paying the FARC a tax:

I pay in accordance with what I sell. So, they say that the coca is 1,000 pesos, you have to pay 100 pesos for taking a pound of leaf, more or less 10 per cent of the value per gram is the value of their take. So, if he sells 1,200 he pays 120. Right now coca is down to only 700, so he pays 70. So, it's conditioned by the price of the sale, and this is enforced by them [the FARC]. They are in charge, yes, it's the rule. You as a producer can't think any other way, because they will find you in violation and charge a fine or you will have to give money, leave the zone, or they won't allow you to work. ... After they [FARC] started collecting taxes from those that worked in the kitchens (cocaine laboratories) ... for example, if 100 kilos comes out, they charge 100 kilos of work. For the planes I think they charge 50,000 pesos. "53

Between 1991 and 1996, Colombian insurgents earned about US\$2.4 billion from the illicit drug trade. That amount comes to 12 per cent of total profits and 5.25 per cent

\footnotetext{
51 Ávila 2011: 8

52 Pizarro 2011: 92; Puentes 2006: 62; Ávila 2011: 8

53 Juan Ferro interview with coca farmer in Florencia, Caquetá, 1999; Ferro 2004
} 
of Colombia's GNP. ${ }^{54}$ Most of the income went to the FARC as a result of taxing the drug trade. In exchange, the FARC offered protection to both merchants and narcotics traffickers from state security forces, as well as guarantees of the quality and quantity of crop offered by cultivators. Indeed, the cornerstone of the FARC's economic strategy was a mutually beneficial exchange of taxes for two basic public goods; economic regulation and local order. What is more, by regulating the economy and establishing order, the insurgents maximized their social control, which coincided with their interest in collecting taxes. They knew who was in the zone, what their activities were, and how much coca they bought or sold. To that end, the FARC used the rents from the gramaje to strengthen their organization militarily, and also to fund the activities of Community Action Boards (JACs) in maintaining order.

\section{Building Organizational Capacity}

In 1985, largely based on the experience of urban militias and civilian abuses, the FARC implemented a new policy of only allowing members of the FARC military hierarchy to serve in roles involving a public order function or the collection of resources. Even the FARC's extensive network of civilian militants could serve only logistical functions, which included gathering information, supplies, weapons, and food. They could not enforce norms of behavior nor collect rents because the FARC's highest authority, the seven-member national Secretariat, wanted absolute centralized control over these activities. ${ }^{55}$ Hence, after 1985 the FARC began transforming its organizational

\footnotetext{
54 Vargas 2002: 34

55 Author interview with Kyle Johnson, research associate with Corporación Nuevo Arco Iris, September 28, 2011, Bogotá, Colombia; the FARC has a large network of civilian militias including the Milicias
} 
structure to directly engage in regulation and taxing activities. Thus the FARC's disciplined organization is in some ways an outcome of the insurgents' encounter with illicit drug cultivation rather than a cause as scholars such as Paul Staniland have argued. ${ }^{56}$

FARC leaders were extremely anxious about the dangers of exploiting a criminal economy. They understood the risk of corruption among lower level commanders in regions with illicit economic activity. Abuse of the population would not only deplete the amount of resources coming back to the organization, but would also undermine popular support and threaten revolutionary goals. ${ }^{57}$ Hence, when the FARC began systematic regulation of the illicit economy, they developed mechanisms of internal control and monitoring. Some of these mechanisms were already in place. By the early 1980s, the FARC had a firmly established reputation for extreme discipline within its ranks and a rigid vertical chain of command. ${ }^{58}$ There is scant evidence that the FARC used economic incentives to recruit; members were not paid a salary, and all members joined for life, separated from family and community. ${ }^{59}$

Bolivarianas and Milicias Populares. The militias move among the population but are the least connected to the organization, making them the most likely to abuse civilians. Militias are never permitted to handle collection or disbursement of organizational resources; Ferro and Uribe 2002: 56

56 Staniland 2012; also see Lidow 2010

57 Jaramillo, et al. 1989: XIV

${ }^{58}$ The disciplinary regime that developed within the FARC is described consistently by individually demobilized members. They describe a consistent, well-known, strictly enforced disciplinary code and norms of behavior including staged trials and excecutions for high crimes such as treason and desertion; Ferro and Uribe 2002, Medina 2009, Currea-Lugo 2007: 108, 112-113, Gutierrez 2006, Rueda 2009

59 There is no evidence that the FARC has ever paid a salary, but as of the early 2000 s they were maintaining their members with food, health services and material conditions. According to one kidnapped victim who was later released, the FARC carry eight days of food with them, and medicines, and every squad has a nurse. Food rationing is strictly controlled and they reportedly eat 'better than the army'; Ferro and Uribe 2002: 90 
However, in 1985 new mechanisms were put in place that specifically addressed the question of resource management. That year, the FARC changed its structure to centralize control over finances and budgets. ${ }^{60}$ Going forward, resources were collected from the base of the organization and immediately passed up to the highest levels to be distributed among the various blocks and fronts. Resource allocation to each front was strictly calculated based on a monitored budget that took into account the basic needs of combatants and need for supplies. The process started with the appointment of one member of the FARC's seven-member national Secretariat to draw up the budget and receive all the funds. A general budget was then determined at the National Guerilla Meeting that took place (ideally) once a year, and included the Secretariat and block commanders. From the general budget, the appointed commander devised specific budgets for every block, front, and commission of the organizational hierarchy. ${ }^{61}$

Every single guerilla had a calculated budget. What is more, the Secretariat kept tabs on how much was spent on itemized food (rice, beans, and meat) in every front, company, and by each individual member. Large or unexpected expenditures had to be pre-authorized. Hence, centralized control not only protects against abuses, but also ensures that there is no 'quality of life' differences between fronts in different regions. ${ }^{62}$ Testimonies of demobilized combatants attest to the strict control over resources, and the absences of salaries or remuneration of any kind. ${ }^{63}$ However, some of the testimonies

\footnotetext{
${ }^{60}$ Ferro and Uribe 2002: 51

61 ibid: 105-106

62 ibid

${ }^{63}$ Rueda 2009: 132
} 
suggest that fronts operating in regions without coca had less funds at their disposal than fronts operating in regions with coca cultivation. ${ }^{64}$

Beyond centralized control over resources, other organizational mechanisms were put in place to further guard against abuses due to the obvious temptations posed by the presence of a very lucrative illicit resource. FARC high commanders, including members of the Secretariat, distributed themselves throughout the organizational structure, with each member of the national secretariat accompanying a different block. Lastly, the FARC implemented a strategy of rotating the lower command among the different blocks and fronts ${ }^{65}$. In this way, the insurgent organization regulated and taxed the illicit market for two decades without succumbing to internal criminalization and civilian predation. ${ }^{66}$

Undoubtedly, there were cases of abuse by lower level commanders. Former FARC commander Julio Rincón testified that there are plenty of stories of FARC members being corrupted by narcotics traffickers in El Caguán, Caquetá. The traffickers offered jobs, alcohol, gifts, money, cocaine, and girls. ${ }^{67}$ One high profile example was the case of Hermides Lozada, Commander of the FARC's $7^{\text {th }}$ front in the coca-producing region of La Macarena, department of Meta. In the late 1980s, Lozada was discharged for collecting excess taxes and for managing resources badly. The $7^{\text {th }}$ Front was then transferred to Guaviare and a new $27^{\text {th }}$ front was created to control La Macarena to help improve the FARC's image ${ }^{68}$ Hence, even taking into account some inefficiencies, the

\footnotetext{
${ }^{64}$ ibid

65 Pizarro 2011: 231, footnote

${ }^{66}$ Guttiérrez 2006

67 FARC commander Julio Rincón in Caquetá, Colombia in 1999; Ferro 2004

68 Ávila 2011: 9
} 
FARC's capacity to identify and punish transgression within the ranks was remarkable. After 60 years of armed struggle there is only one known case of a rebellion within the FARC's ranks. ${ }^{69}$

\section{Economic Regulation}

Afterward the guerillas started to sanction, to take their taxes from coca, to control the purchase of coca and to make all the rules in the community. It was no longer the selfdefense [militias] because they disappeared but it was them [the FARC] that started to ac. directly. ${ }^{70}$

By the early 1990s, roughly 20 per cent of FARC combatants were directly engaged in economic protection activities in regions with illicit crops. ${ }^{71}$ By 1998 , the proportion had increased to about one-third. ${ }^{72}$ Regulations controlled production levels, prices, and the size of the labor force. ${ }^{73}$ The goal of the regulations was to protect against coca price volatility, ensure a constant food supply in the region, and protect farmers from the predatory practices of coca merchants. When coca prices declined, the result was chaos in Caquetá. Hence, two specific regulations were key. First, the FARC required early on that illicit farmers also grow basic food items. Second, the FARC monitored exchanges between intermediaries and peasant farmers to ensure fair payment.

First, the FARC instituted rules to ensure the continuation of growing food crops early on. At the $7^{\text {th }}$ conference in 1982, the FARC first implemented the rule that peasants

\footnotetext{
${ }^{69}$ The rebellion of the Ricardo Franco front of the FARC took place in 1983. It was led by Javier Delgado, the former finance secretary of the FARC. Delgado deserted, taking 80 million pesos and several FARC commanders with him. However, the movement quickly succumbed to internal violence. Two years after its founding, common graves were found with the murdered remains of the members of the Ricardo Franco Front. Ricardo killed 164 of their own combatants reportedly for minor offenses like saving bullets. They were hung in the 'old style of the FARC'; Currea-Lugo 2007: 118; Ferro and Uribe 2002: 59-60

${ }^{70}$ Juan Ferro interview with a community leader in Cartagena del Chairá, Caquetá, in 1999; Ferro 2004

${ }^{71}$ Ortíz 2002: 137

${ }^{72}$ Rangel 1998

${ }^{73}$ ibid
} 
growing illicit coca would be required to grow three hectares of traditional crops for every one hectare of coca. ${ }^{74}$ The rule was intended to reduce dependence on imported food and price inflation and to inhibit the formation of counter-revolutionary forces in the region. ${ }^{75}$ When the price of coca plummeted in 1982, the food scarcity that ensued was a major threat to stability in the region. Even as late as 2001, the FARC was still obligating farmers to continue planting traditional crops. According to a local priest in San Vicente del Caguán, it was not uncommon for the FARC to withhold payment to ensure that farmers continue growing food for their own consumption. ${ }^{76}$

Second, the FARC directly monitored exchanges between the intermediaries that purchased coca and the peasant farmers that produced it. Prior to the FARC, coca merchants were notorious for abuses such as over-charging so they could take a cut, or using violence to avoid payment. As one local describes the process, "The large buyer would arrive and give money to four, five, or six people, and receive a 'utility margin' of 10,000 or 20,000 [pesos] per kilo." The FARC responded to the situation by requiring peasants to sell their product at 'selling posts.' There, a FARC member monitored the exchange and collected their 10 per cent tax, which was paid by buyers and sometimes medium and large coca farmers. Small growers and raspichenes or 'harvesters' were mostly exempt. ${ }^{77}$

\footnotetext{
74 Author interview with Kyle Johnson, research associate with the Corporación Nuevo Arco Iris, September 28, 2011, Bogotá, Colombia

75 Ávila 2011: 8

${ }^{76}$ Soto-Trillo 2001: 106

${ }^{77}$ Ferro 2004
} 
In addition, to maximize control over the sale of coca, the FARC required that coca merchants be residents of El Caguán. In 1999, FARC Commander Camilo explained that when he was in El Caguán during the 1980s, the majority of coca was bought by the Cali Cartel. Commander Camilo explained that he knew it went to Cali because the majority of merchants in El Caguán sold to the peces gordos (fat fish) in Cali, that the planes used to transport the merchandise were from Cali, and those who paid the FARC their fees were people from Cali or at least 'that's what they told us.' He goes on to say that in Caquetá, there were never any paramilitary groups working for the cartel capos. ${ }^{78}$ Another FARC commander Julio Rincón explains:

"[W] hat happens is those that buy are people from Caquetá, there weren't any of the fat fish, because the fat fish never came to the zone. If they did, and the fat fish were suspected of patronizing paramilitary groups, we would have been able to take them, or if we were able to kill them we would have. We couldn't because that was out of our reach. Those who bought lived in the zone and submitted to our rules: don't carry arms, or at most a revolver and never a 9mm. Do not bring people whom you don't know, and if you bring someone you are accountable for what they do in the zone." 79

Finally, in addition to regulating the growing of food and monitoring exchanges between farmers and intermediaries, the FARC was also a source of credit, providing loans, mortgages and savings to peasants who could not afford these services at the stateowned Agrarian Bank. All the while, the FARC continued to support economic development projects such as 'El Modelo Caguán’ with surplus from illicit rents. ${ }^{80}$

\footnotetext{
${ }^{78}$ FARC commander Camilo in San Vicente del Caguán, Caquetá in 1999; Ferro 2004

${ }^{79}$ FARC Commander Julio Rincón in San Vicente del Caguáñ, Caquetá, 1999; Ferro 2004

${ }^{80}$ López 2007: 142
} 
In essence, the FARC became an 'intermediary on behalf of small producers,' providing regulations such as a fixed price on coca base that decreased the high risk and insecurity that came with involvement in a criminal economy. Over time, the regulations extended to also include supplying air fields (for a fee), constructing and maintaining processing labs, and protecting export routes. ${ }^{81}$ Because many of these services benefited narcotics traffickers, the FARC's relationship with the traffickers was cooperative and mutually beneficial. For example, the Medellín cartel paid fees to the FARC for protection of the Tranquilandia hacienda an enormous cocaine laboratory discovered by Colombian authorities in $1984 .{ }^{82}$

Indeed, one resident of Caquetá who came to the area in the 1980s to plant coca described the FARC's relationship with narcotics traffickers as 'more permissive and tolerant' than with other sectors and adds that the insurgents and narcotics traffickers were "more or less partners." 83 Certainly, the FARC and narcotics traffickers had conflicting political agendas at the national level. The traffickers' profit interests were linked to the existing power structure and the FARC was fighting to undermine that structure. ${ }^{84}$ Hence, the FARC never solidified a political alliance with narcotics traffickers analogous to their alliance with peasant coca growers. However, in Caquetá

\footnotetext{
${ }^{81}$ Initially most peasant coca growers were exempt from the tax, but the intermediaries who purchased from small producers paid a 10\% tax on their purchase; Tickner, et al. 2011: 417-18; Pecaút 2008

82 Puentes 2006: 7, 48; Ortíz 2002: 137

${ }^{83}$ Coca farmer in northern Caquetá; Ferro 2004

${ }^{84}$ At the national level, the FARC considers narcotics traffickers and the drug cartels to be enemies of the revolution; Currea-Lugo 2007: 107
} 
and other parts of the Western Amazon, the FARC and narcotics traffickers forged a cooperative commercial alliance. ${ }^{85}$

\section{Internal Order}

[I]ndisputably the first productive cycles of coca were very violent, it was a no man's land, a 'wild west.' There are testimonies of people from that era that at that time all producers were armed, and had bodyguards, and some even paid dishonestly by eliminating people. There was no respect for life. Precisely in that space of no man's land the FARC took advantage of a moment, and they started to create a type of social order, to start to dictate some standards of behavior, and it is from this moment that they really come in contact with illicit cultivation. ${ }^{86}$

...the tranquility with which the guerillas passed through the town. One saw trucks full of guerrillas all over ... in 'Caquetanía. ${ }^{87}$

In addition to economic regulation, the FARC developed mechanisms for imposing law and order in the coca growing communities of Caquetá. The colonos communities demanded a remedy for the crime and disorder that accompanied coca, and the FARC could hardly regulate and tax the economy without some semblance of order. At first, the FARC formed independent committees to do the work of creating and enforcing a criminal code. However, these committees were in competition with the local JACs. Despite the JACs' inability to govern after the coca bonanza, the authority of the JACs was seen as more legitimate by locals because JACs were commissioned by the national government, even though the government had long since cut off ties and financial support. Hence, the FARC re-established order by militarily and financially

\footnotetext{
${ }^{85}$ Currea-Lugo 2007: 107

${ }^{86}$ Doctor and historian in Cartagena del Chairá, Caquetá, Colombia ; Ferro 2004

${ }^{87}$ Former FARC combatant (deserter) describing her arrival in El Caguán, Caquetá as a FARC combatant on July 11, 2001; Rueda 2009:33
} 
backing the Community Action Boards (JAC). The strategy worked, even though it was understood that the FARC was the power behind the JAC.

In 1982, the FARC created Social Action Committees (CAS; Spanish acronym) in Caquetá and Guaviare in an attempt to impose law and order during the catastrophe of the first coca price bust. ${ }^{88}$ With the military backing of the FARC, the CAS was supposed to 'fill the gaps' created by state neglect of the region so that the FARC could focus on building a military structure and fighting a war. Indeed, at that time the FARC was not interested in supplanting the state, but rather sought state intervention to eradicate the coca problem. The Social Action Committees were intended to keep order in the meantime. However, the local community was slow to accept the authority of the CAS mostly because the Community Action Boards (JACs) were still present.

The JACs were created by the national government in the $1960 \mathrm{~s}$ to control frontier colonization zones, only to be abandoned by Bogotá in the 1970s. Indeed, the JACs were created as a political response to the radicalization of the peasantry during the 1960s. ${ }^{89}$ It was hoped that through the JACs the state could respond to and subdue the unrest. However, the JACs were locally elected bodies and in rural areas where the Colombian Communist Parties (PCC) had influence they became arenas for radical peasant organization. For that reason, the state cut off funding; however, the organizations themselves were never dismantled and continued to govern autonomously in isolated frontier regions.

\footnotetext{
${ }^{88}$ Jaramillo, et al. 1989: 252-253

${ }^{89}$ In particular, the JACs were a response to the formation of a national peasant organization, the Asociación Nacional de Usarios Campesinos (ANUC). ANUC provided organization to radical peasant uprisings in the countryside.
} 
In Caquetá, JACs were the main force behind frontier development in the 1960s and 1970s. Prior to the coca bonanza, the colonos communities actively participated and made demands on government through their local JACs. The local JAC was at the center of civic life in frontier neighborhoods. Through these committees, the colonos organized community initiatives to autonomously build schools, roads, and health clinics, establish new villages, and even provide credit to small merchants. ${ }^{90}$

The authority of the JACs was greatly diminished between 1979 and 1985 because these local organizations controlled by local settlers were overwhelmed by the influx of outsiders and generalized chaos brought by coca. Nonetheless, the JACs did not dissolve. The colonos continued to vote in new members and attend the meetings, though the floating population did not participate. The colonos also continued to bring their concerns to the JACs knowing the JAC was powerless to enforce any decision or remedy. Interestingly, even after the state cut off ties, the JACs were still seen as legitimate because they were a creation of the central government and the only link to the state after the failure of the peace talks in 1985. The population of Caquetá urgently sought recognition and political inclusion vis-à-vis the national government as a solution to the problem of coca cultivation and this is why they continued to look to these organizations for governance. ${ }^{91}$ Local testimonies capture this sentiment:

We are people that need to be within the law because it [the JAC] is the most legal means to make demands on the center of the country and it provides legal protection against repression. It gives us the right to go and demand government assistance because it [the JAC] is legal and we can in that way

\footnotetext{
${ }^{90}$ Uribe 2002: 221

${ }^{91}$ Author Interview with Kyle Johnson, research associate with Corporación Nuevo Arco Iris, September 28, 2011, Bogotá, Colombia; also see Ramírez 2011
} 
request public works. Because it [the JAC] is the only means for acquiring official money, material support, and aid. ${ }^{92}$

Because of the legitimacy of the JACs, the FARC Community Boards lasted only two years before being dismantled in 1984. They were not brought back in the aftermath of the failed peace talks. Instead, the FARC began to strategically finance and militarily back the authority of the Community Action Boards (JACs). Indeed, by far the most important factor in the FARC's enforcement of order was their military support for the work of the Community Action Boards (JACs) in Caquetá. ${ }^{93}$

By the end of the 1980s, it was clear that the JACs were working closely with the FARC. Even during the peace talks with President Betancur, there was open cooperation between the FARC and the JACs in designing and presenting the Development Plan of Lower Caguán. Hence, when the government abandoned the development project at the end of 1985, the FARC essentially co-opted these institutions by infusing them with authority and capital. Almost immediately, the FARC established a rule obligating all residents, including coca merchants and harvesters, to attend JAC meetings. ${ }^{94}$ From that point the JACs were hardly autonomous from guerilla authority and indeed were the main

\footnotetext{
${ }^{92}$ Jaramillo, et al. 1989: 257

${ }^{93} \mathrm{JACs}$ formed in 1958 under Act 14 as community-based organizations that would carry out development projects with state and local funds. The JACs were made up of local residents. They were delegated orderkeeping 'vigilance' functions and the authority to manage public services. The state's intention for the JACs was to pacify rural unrest. However, over time the government financially and politically abandoned JACs. Control of the JACs was then usurped in many instances by non-state armed actors, including the FARC; Brittain 2010: 160-161

${ }^{94}$ Jaramillo, et al. 1989: 257-258
} 
conduits for the FARC's political agenda ${ }^{95}$. JAC members backed the political work of the guerilla and identified with the guerilla leadership. ${ }^{96}$

Under FARC tutelage and economic support, and without any national government support, the JACs returned to their work constructing schools and river ports, and participated in the founding of new towns. The work itself was organized and carried out by the JAC, but it was understood that the FARC was behind the public works projects. As one local explains:

In these regions, development is practically linked to the armed movement. In other words, it's difficult to find the construction of a school in El Caguán that hasn't been an initiative or the product of the armed movement. The majority of schools, of the roads have resulted from the ongoing activity of the organizations developed by the armed movement. To give very concrete examples, the Remolino secondary school; this school is practically the product of a FARC initiative with the parents and people of that area. In addition, the FARC was the one that established the tradition of the so-called 'beer bonus,' a voucher program that financed the salaries of the teachers. Because those teachers were not contracted by the State. It was a diploma recognized by the Ministry of Education, from the perspective of their officials, but the program was the outcome of activities organized by the FARC. In El Caguán there is a committee called 'Pro-River Committee' including a river toll. ... It's the only river toll in Colombia and we invented it and with this river toll, that controlls the traffic in the river, with this tax, they have constructed any number of public work projects on the River Caguán. The improvement of all the ports and the infrastructure has been done with the money collected by this Committee. It's all been financed by the Pro-River Committee. Even a rescue team, we put it together using only the resources gained through the tax. Related to roads, bridges,... those bridges that are in Santa Fe are bridges practically organized by us, those roads that they are constructing to link El Caguán with Los Llanos del Yarí, that is the work and initiative of the FARC, together with the communities of that region. Some neighborhoods have been constructed with a timber tax that they [the FARC] charge to some private operations from specific regions. ${ }^{97}$

\footnotetext{
${ }^{95}$ Brittain, 2010: 160-169; Uribe 2001: 222-223; Jaramillo, et al. 1989: 251

${ }^{96}$ Jaramillo, et al. 1989: 258

${ }^{97}$ Resident of Cartagena del Chairé; Uribe 2002: 217-218
} 
In addition to public works projects, the FARC worked with the JACS to develop mechanisms for policing in order to deal with the rapid increase in violence and crime brought by coca cultivation. To enforce order, the FARC created a five-member Civilian Surveillance Committee within the JAC charged with the specific task of controlling quarrels, scandals, theft and other 'manifestations of social decay' in Caquetá, and especially in the lower Caguán region where coca was cultivated. ${ }^{98}$ The Committee also designed education programs for crime prevention, and participated in formulating appropriate sanctions.

Punishment of crime in Caquetá followed a very strict and organized code. First, different crimes were organized into two categories: delitos (high crimes) and faltas (misdemeanors). The Surveillance Committee implemented harsh punishments for crimes called delitos such as homicide, rape, and violent theft. Faltas were mere transgressions or violations of a less serious nature punished with fines and sometimes forced labor. The list of minor transgressions included poor farming practices, an untidy property, and environmental abuses such as deforestation and fishing with dynamite. ${ }^{99}$ These rules are summarized into a code of behavior called the Ley del Monte (Law of the Mountain). According to a FARC commander in Caquetá, the following rules are included in the Ley del Monte in all zones under FARC control: ${ }^{100}$

- No fishing with dynamite

- No travel by river or land between 6 pm and 6 am

- Keep public roads and house facades neat

\footnotetext{
${ }^{98}$ Espinosa 2000; Pataquiva 2007: 46

${ }^{99}$ Ruiz, 2001: 27; Pataquiva 2007: 47-48

${ }^{100}$ Cambio 16, November 2, 1998, Despeje o despelote?, pp. 23
} 
- Do not hunt native species. One capybara death will incur a fine of 500,000 pesos

- Leaving animals out of their paddocks after 6 pm will incur a fine of 50,000 pesos. It is inhumane that while the owner gets drunk the animal endures hunger and dirties the streets

- Insults, a50,000 peso fine

- Gossip, a50,000 peso fine

- Fighting, a fine of 200,000 pesos plus the medical costs of the affected party

- Threats involving a knife, a fine of 100,000 pesos

- Threats involving a gun, a fine of 200,000 pesos

- Closing a public establishment after the appointed time (12 midnight during the week and 2 am during the weekend), a fine of 200,000 pesos

- The noise level of the establishments should be moderate

- Logging is permitted up to 20 hectares per person maximum with the obligation to replant the trees. A maximum of 20 blocks of wood/week per person.

- Punishments are also enforced for drug addiction, theft, rape, and domestic violence

The FARC protected the community against drug addicts, but did not interfere much in other moral and social issues. Indeed, the FARC did not target social 'misfits' such as homosexuals who challenged the communities' traditional values. Nor was the FARC interested in regulating drinking, smoking, or prostitution. As one local comments, "to be drunk in San Vicente at $1 \mathrm{pm}$ is normal; it's part of our culture."101 However, the FARC was harsh on drug addicts, and regularly evicted them from the region. Drug addiction was a major problem in Caquetá, not only because of its deleterious social effects, but also because narcotics traffickers encouraged addiction as a way to avoid paying illicit producers; they would offer drugs in place of cash. The FARC dealt with

${ }^{101}$ Soto-Trillo 2001: 77, 95, 104 
the problem by prohibiting payment to coca growers in drugs and prohibiting drug abuse. $^{102}$

One cannot overlook the central role of the JACs as locally elected organizations in the formulation and enforcement of these rules and ordinances. What is more, the JACs directly organized public works such as construction of schools and health clinics. The role of the FARC was to force cooperation with the JACs' rules so that the community could enjoy collectively beneficial public goods. ${ }^{103}$ Nonetheless, the local community and outside observers viewed the JACs as institutional appendages of the guerilla organization with very little decision-making autonomy. Hence, it is not uncommon for policy makers, local residents and even scholars to credit the FARC for the provision of public services in Caquetá. As one scholar explains, "In many municipalities of these areas, the only authority, beyond the symbolic state police station in the capital centers of the municipalities, is that of the FARC, and [FARC] is the sole provider of essential public services." 104

Perhaps the one area in which the FARC played a direct role in the maintenance of order in Caquetá is that of adjudicating disputes and enacting punishments, particularly for more egregious crimes. The FARC set up autonomous judicial institutions to carry out these functions. In Cartagena del Chairá, a municipality in the lower Caguán region, the 14th Court of the FARC heard accusations and enforced punishments. The Court was

\footnotetext{
102 Author interview with Kyle Johnson, research associate with the Corporación Nuevo Arco Iris, September 28, 2011 in Bogotá, Colombia

103 The FARC directly funded and executed road construction only when it was needed for military purposes. On occasion, the FARC paid teacher salaries and opened clinics but such activities were exceptional.

${ }^{104}$ Ortiz 2002
} 
reportedly run by a junior officer of the guerillas. The FARC also opened a 'Complaints Office' in San Vicente del Caguán, the capital city of Caquetá. Reportedly, people travel from all regions of Caquetá to settle their domestic and neighbor disputes before the FARC. There, the parties are heard, the guilty party identified, and some resolution is granted, whether it be paying for damage to a neighbor's property because of negligence or covering medical expenses due to a quarrel. ${ }^{105}$

The essential role of the FARC in maintaining order in the lower Caguán region of Caquetá was all too evident when the insurgents temporarily abandoned the region in 1991 and chaos ensued. After failed peace talks with President César Gaviría (19901994), the government launched a successful military attack on the FARC's center of operations at Casa Verde (Green House), which was located in the municipality of La Uribe in the department of Meta. ${ }^{106}$ As a result of the attack, the FARC temporarily evacuated from town centers in Caquetá, including Cartagena del Chairá and Remolino in El Caguán. In the FARC's absence, the law of the strongest returned. As one local describes it:

When the peace process broke down, the guerillas abandoned Remolino. After the guerillas left, the people started killing. It was the era in which accounts were settled. The employer that did not pay a worker, he went and killed him to collect the wages. The man that went with another's wife, he went and killed him for that. The old woman who left her husband for being a scoundrel, he looked for her and killed her because she had abandoned him. The two boys that had quarreled in school, they sought each other out and settled accounts. It was without God, without law, and without protection of any kind. On a Sunday there would be up to 12 deaths in the urban center, on the sidewalk a trail of cadavers through Cartagena. ${ }^{107}$

\footnotetext{
${ }^{105}$ Soto-Trillo 2001

${ }^{106}$ Ferro and Uribe 2002: 30

${ }^{107}$ Local peasant farmer in Remolino, a municipality near Cartagena del Chairá; Uribe 2002: 227
} 
In response to the situation, the leaders of the Community Action Board called a meeting, and a letter was sent to the Commander of the FARC's Southern Block, Fabián Ramírez, requesting that the guerillas take some measures to improve the situation. Local witnesses tell that Fabián returned to Remolino and started to impose order. Specifically, he established a rule that killing without just cause such as legitimate self-defense would be punished by execution in the center square. According to testimonies, no one was executed by the FARC during that time, but within three months there ceased to be any more deaths, neither in the neighborhoods nor in the town center. ${ }^{108}$

Finally, in addition to maintaining order, the FARC also supplied direct protection against the state, and specifically the anti-narcotics police. The insurgents assisted the peasants in hiding their illicit crops, and militarily targeted anti-narcotics police carrying out operations in the region. Table 5.3 demonstrates the FARC's use of force to impede state efforts to fumigate illicit crops between 1995 and 1997. In addition to military efforts, the FARC also organized community opposition to forced eradication efforts, including the 1996 cocalero marches in which some 200,000 peasants in the Amazonian and llanos regions of Colombia participated in a protest against aerial fumigation. ${ }^{109}$

Table 6.4, Insurgent Violent Actions against Anti-Narcotics Police, 1995-1997110

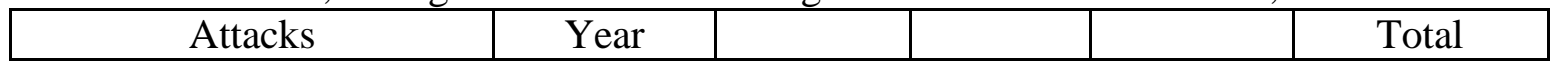

\footnotetext{
108 Uribe 2002: 228; Ferro 2004

${ }^{109}$ Ramírez 2011; Vargas 2002

${ }^{110}$ Vargas 2002: 35
} 


\begin{tabular}{|c|c|c|c|c|c|}
\hline & 1994 & 1995 & 1996 & 1997 & \\
\hline Aircraft Damaged & 3 & 5 & 19 & 13 & 40 \\
\hline Aircraft Downed & 14 & 21 & 11 & 8 & 54 \\
\hline Helicopters Damaged & & 3 & & & 3 \\
\hline Killed & 9 & 22 & 0 & 1 & 32 \\
\hline Wounded & 7 & 43 & 1 & 9 & 60 \\
\hline
\end{tabular}

\section{Legitimate Authority}

During a 2001 visit to the department of Caquetá, Spanish journalist Eduardo Soto-Trill wrote about the remarkable delivery of public goods in a zone that had been practically abandoned by the national government. He described the excellent condition of the roads and the FARC's posters that read 'No Burning, No Littering, Protect the Fauna.' He noted the many signs of public works and development projects. He commented on how cement speedbumps are used on the roadway to force drivers to reduce their speed, and the many newly constructed wooden houses. There were sidewalks, drains and gutters for rainwater, markets full of merchandise, and colorful ice cream shops and coffee shops. It appeared 'more like a summer resort than a guerilla capital. ${ }^{111}$ On the road, there are new European and Japanese cars, and in the town there is little sign of poverty. Uniformed FARC guerillas mix with the people, doing their

${ }^{111}$ Soto-Trillo 2001: 48 
Sunday shopping or having a drink. This is daily life in El Caguán. "All of this tranquil bureaucracy confused me." 112

Soto-Trillo's observations contradicted the accepted view of Caquetá under FARC's control. In Colombia and even internationally, outsiders who had not visited the zone imagined a black hole of authority where FARC guerillas preyed on an indefensible civilian population. And yet Caquetá was a vibrant, well-ordered community. Ironically, the order and prosperity that Soto-Trillo observed was linked to the absence of the state in the coca-growing department. State neglect and repression had created a space for mutually beneficial exchanges wherein the FARC satisfied resource needs by supplying public goods. The result was symbiotic ties between insurgents and civilians and legitimate insurgent authority defined as governance by consensus or mutual exchange, and perhaps even a short period of prosperity for the poor and politically ostracized region.

The following paragraphs offer evidence of legitimate authority in Caquetá. I define legitimate authority as authority that expresses the common will; what Timothy Wickham-Crowley calls 'guerilla governance.' Guerilla governance results when insurgents carry out three contractual obligations: defend the people from external enemies, maintain internal order, and provide material security. "As a result of such activities, peasants often come to perceive the guerrillas the new legitimate authority in the region." 113 I capture the FARC's legitimate authority with evidence of civilian support (witness accounts), political participation, direct participation (recruitment), and

112 ibid: 24

${ }^{113}$ Wickham-Crowley 1987: 473 
failure to cooperate with the FARC's armed rivals - particularly right-wing paramilitaries. Finally, I discuss the formation of a FARC-controlled demilitarized zone as evidence of FARC legitimate authority. Not only did the civilian population remain after the government announced a demilitarized zone, but they report improved quality of life conditions.

\section{FARC Authority by Consent}

After conducting extensive research in the department of Caquetá in 1999, Juan Guillermo Ferro concluded that the FARC's involvement in the illicit coca economy had different effects on public support in Colombia's coca-producing regions than on the country as a whole. At the national level, the FARC's involvement in the illicit economy and their strong ties to coca producers resulted in a significant decline in popular support for the insurgents, particularly in urban areas plagued by drug violence. ${ }^{114}$ However, Ferro finds that FARC involvement in the illicit economy did not cost them any public support in Caquetá, and in fact was the basis for a very high level of local support.

\section{$\underline{\text { Civilian Testimonies }}$}

Civilian testimonies reveal a general sense that the FARC made Caquetá a better place; that in the absence of the FARC the civilian population would be much worse off even though the insurgents were authoritarian, and at times unjustly violent. One local explains:

Nonetheless, these actions give some legitimacy to the guerillas, to the extent that everyone accepts that with organization things work better. They

\footnotetext{
${ }^{114}$ Ferro 2004
} 
brought to a popular organization the fruit of authoritarianism that reinvigorated the Community Action Boards that are institutions created by the state, but that the FARC recognized as basic organizations of the community in general. Although people are scared, this does not mean that they are against the methods of the FARC in organizing the people. There is authoritarianism not only in the FARC, but also in the population itself. ${ }^{115}$

Others express a sense that the FARC is more legitimate than state functionaries because they are less corrupt and more efficient in solving problems. The following civilian testimonies capture this sentiment. The first was given by a woman in the waiting room of the FARC's Complaints Office in San Vicente del Caguán. The second is the testimony of a government official working in the Mayor's Office in San Vicente. Both testimonies were recorded in 1999:

We come here to resolve our problems because we trust in their justice. They aren't corrupt like the judges in Puerto Rico. ... The agreement that we arrive at before the FARC will be done securely and will save time and money in lawyers. ${ }^{116}$

The FARC respects the public offices, they do not mess with them. But when people abandon their responsibilities they come and they punish them. They take their car, house, or they hold them ... because the only abuse that the FARC commits are the detention-kidnappings. Then, someone goes to talk to them, they make them wait, sometime after they answer that 'it's in process,' which means that they have the person. In a few days they either let him go or they impose a penalty. Whichever - the FARC passes through and the people wave from their doorsteps. ... When we have a meeting my colleagues say to me 'here comes the independent republic, 'and it's true. ${ }^{117}$

Finally, perhaps the most common justification for supporting the FARC in Caquetá was simply that the insurgents got things done, whereas the state demonstrated a lack of will or capacity. Indeed, civilian testimonies rarely captured a religious zeal for

\footnotetext{
${ }^{115}$ Peasant coca cultivator in Caquetá in 1999; Ferro 2004

${ }^{116}$ Local resident at the FARC's Office of Complaints in San Vicente del Caguán; Soto-Trillo 2001: 97-98

${ }^{117}$ Government functionary in the Mayor's Office in San Vicente del Caguán; Soto-Trillo 2001: 68
} 
the insurgents' cause, nor an uncritical acceptance of their ideological views. Rather, there was a pragmatic acceptance that the FARC was the rightful authority because, in the end, they were a source of order and economic security. For example, one resident of Caquetá described the construction of a road that greatly facilitated travel and transport in the region, and that was constructed by the FARC for a far lower cost than would have been the case with the government:

The guerilla carried out some of the public works that were failed promises of the national and departmental governments. Here we are attached to the municipality of La Macarena, also part of the demilitarized zone some 90 kilometers to La Sombra, by a road constructed by the FARC, that didn't cost more than 300 million pesos, and that years ago had been budgeted by contractors with particular links to local politicians for more than twice that amount. Before, one reached La Macarena by impassable trails on a grueling journey of 10 or 12 hours. $^{118}$

\section{Voluntary Mobilization: The Cocalero Marches}

The FARC's legitimate authority in Caquetá and other parts of the Western Amazon is also marked by widespread participation in protests against chemical fumigation of illicit crops in 1996. The FARC played a leading role in organizing the protests, which lasted for three to ten months in different locations. The guerillas successfully mobilized more than 200,000 women, children, and indigenous people to leave their farms and demonstrate in town centers at government seats. ${ }^{119}$ The marches themselves were a massive demonstration of the FARC's authority and collective power in coca-growing regions. But, perhaps most important, there is strong evidence that the population participated willingly, linking their economic interests to the political and

\footnotetext{
${ }^{118}$ Resident of La Sombra, a community on the outskirts of San Vicente del Caguán; Ferro 2004

${ }^{119}$ Ramírez 2003
} 
economic agenda of the FARC. In 1996 as in 1985, the population of Caquetá desperately wanted to engage the state, and to reject the criminal identity that was imposed on them and that resulted in their political exclusion from the national program. ${ }^{120}$ Many in Bogotá condemned the protest as entirely staged and coerced by the FARC. However, María Ramírez, a Colombian anthropologist who did extensive field work in the Western Amazon, finds that while cocalero marches were planned and facilitated by the FARC, popular participation was voluntary and even enthusiastic. The protests provided an opportunity for the expression of real political grievances by an excluded population. ${ }^{121}$

Indeed, the FARC played a pivotal role in generating collective action. The high level of participation indicates high trust in the insurgents' capacity to protect cocagrowers. Civilian participation in the marches was risky since the coca farmers were publically identifying themselves as participants in a criminal activity, and hence it was a form of self-incrimination. If the peasants participated, it was because they had some guarantee that they would be marching alongside thousands of other coca farmers. This was necessary to overcome an inherent collective action problem. That guarantee was the FARC. One member of the FARC describes the preparation for the marches:

In El Caguán it was almost a year of work. In order to be able to do the marches, it was practically daily work with each of the neighborhoods, calculating the budget, collecting the money and preparing the infrastructure. That lasted six months and of course, it was work building awareness, explaining to the people the effects of fumigation. They

\footnotetext{
${ }^{120}$ Ramírez 2011

${ }^{121}$ Ramírez 2003, 2011
} 
understood that it was a defense of their subsistence. Iit was explained to the people that the fumigations could truncate all of their economic projects. There are people who have practically all of their investment in the region of Caguán. In a way, we played a catalyzing role in the marches, we made the peasant population of the region see that to a large degree the entire economic project in the region was in danger. ${ }^{122}$

Local testimonies suggest that the FARC organized the cocalero marches of 1996, but that community participation was voluntary. The FARC was instrumental in providing resources so that the strike could last for ten months and also providing support for the peasants to negotiate with the government 'from a strong position.' ${ }^{123}$ The FARC provided buses and other forms of transportation, and organized cooperative efforts to deliver food and supplies to the protestors. Within the communities, the FARC's selfinterest in the marches was acknowledged. The FARC used the marches to demonstrate their power in the region, thereby increasing their bargaining power vis-à-vis the State. However, residents also felt that the community benefited from the FARC's display of power. Few believed that the wellbeing of the community was the FARC's top priority. However, many believed that by pursuing their interests the FARC was providing for the common good. One peasant's explanation of the cocalera marches captured this sentiment:

I believe the primary motive was to make the government see that they [the FARC] could. That they are the Revolutionary Armed Forces, as they called themselves, and that they can put the country in jeopardy and demonstrate to the Military that what they say goes. And second to do something to protect the peasantry because in any case the fumigation wasn't helping the farmer

\footnotetext{
${ }^{122}$ Ferro 2004

${ }^{123}$ Ramírez 2003
} 
much, right? As long as there is coca there is money, for everyone. But that they put together the protest only and exclusively in favor of the peasant, I don't believe it. In my view of things I don't believe it. They had two objectives, one was to demonstrate to the Government and public opinion and at the national and international level that they can, that they are in control ... and secondly, yes, to support 30 percent or 40 per cent of the peasants. $^{124}$

Finally, the cocalero movement was a continuation of coca growers' demands for state recognition. The marchers were demanding political inclusion. What they wanted was a dialogue with the government; a coordinated effort between state and society to bring in some basic public services. Ramírez explains, "Stigmatized as guerrilla auxiliaries and criminals, cocaleros began demanding political recognition and increased participation in decision-making. ... State-fostered repression and marginalization has created a strong civic movement that demands state protection and economic aid." ${ }^{125}$ The marches brought state representatives to the region to meet with community representatives. ${ }^{126}$ The result was a mutual agreement, and promises on the part of the state to provide logistical and economic support, and to suspend forced eradication of coca. In return, the coca growers would plant legal alternatives and eradicate their own illicit crops. Unfortunately, the state failed to deliver most of the promised infrastructural support. Not surprisingly, coca growers were equally reluctant to eradicate their illicit crops.

\footnotetext{
${ }^{124}$ Peasant coca cultivator in Caquetá; Ferro 2004

125 Ramírez 2003

126 ibid
} 


\section{$\underline{\text { Voluntary Recruitment }}$}

Forcible recruitment by the FARC in Colombia is rare. While some analysts and journalists assume that forced participation takes place, many more reputable organizations including Amnesty International, the Immigration and Refugee Board of Canada, and the United Nationals Children's Fund (UNICEF) along with a long list of academic experts find little evidence that the FARC recruits forcibly. ${ }^{127}$ In my 36 interviews with demobilized FARC members, not one reported being forced to join. Indeed, what is most striking about the military growth of the FARC since the 1980s is that the organization attracted some 20,000 voluntary recruits without using economic incentives. What is more, it is common knowledge that when one joins the FARC they join for life (or until the revolution is won) and will be permanently separated from family and community, including young children. Life within the FARC is harsh. And yet, as one reporter puts it, in rural areas there is "a seemingly inexhaustible supply of soldiers" for the armed organization. ${ }^{128}$

In particular, the FARC recruited a high number of volunteer soldiers in the cocagrowing regions in the Western Amazon and llanos frontier. Based on interviews with over 500 demobilized insurgents and paramilitaries in Colombia, Arjona and Kalyvas conclude that 'sovereignty' or the perception that one armed group exercises legitimate and uncontested control is a major reason for voluntarily joining one of the armed

\footnotetext{
${ }^{127}$ Immigration and Refugee Board of Canada, 2008; Guttiérrez 2004, 2008; Arjona and Kalyvas 2009; Ramírez 2011; Brittain 2010

${ }^{128}$ Immigration and Refugee Board of Canada 2008
} 
groups. ${ }^{129}$ Indeed, in Caquetá conditions in the region and the authority of the FARC is evidenced by a steady stream of voluntary recruits, though many were less than 15 years old. ${ }^{130}$ Indeed, even while forced recruitment is low, there is evidence that the FARC has recruited children. ${ }^{131}$

Demobilized FARC combatants provide a number of reasons for joining the FARC. Some are ideological, though most refer to poverty and a lack of alternative opportunities as major contributing factors. One reoccurring explanation for joining the FARC that I found in my research and that supports Arjona and Kalyvas' findings is vengeance. ${ }^{132}$ In the case of Caquetá, the FARC benefited from a surge in voluntary recruits who joined in reaction to state repression and neglect that gave legitimacy to the FARC's cause. The direct, positive effects of state repression of FARC recruitment is demonstrated by the influx of peasants into the ranks of the FARC in the months following the state's violent response to the cocalero marches of 1996. A civilian participant in the marches explains:

[T] he confrontation here with the public forces with the military was very hard. That experience caused many of the peasants that were in the marches, people that did not have property, harvesters, we talk of raspachines too, many people that were in the peasant marches, that were in the fight, that saw the dead fall, that saw the injured fall, that saw family members fall, after the marches they became peasants with practically nothing. There has been a massive increase in the ranks of the guerilla, without showing official data, but the peasants will tell you, you saw it, when you went to a region you

\footnotetext{
${ }^{129}$ Arjona and Kalyvas 2009

${ }^{130}$ Workers at a local welfare office in San Vicente del Caguán report that a number of factors contribute to a high number of local youths joining the guerillas. Conditions in San Vicente, including poverty, domestic violence, and child abuse, contribute greatly to the FARC's recruitment success. However, forced recruitment did not seem to be taking place at that time; Soto-Trillo 2001: 93

${ }^{131}$ Immigration and Refugee Board of Canada 2008

${ }^{132}$ Arjona and Kalyvas 2009
} 
notice that there were 10 or 15 from this neighborhood, because the people experienced this. The confrontation with the public forces was very heavyhanded. Meanwhile the peasants were armed with sticks and machetes because they didn't have anything else, the military attacked them and that got out at the national and international level. Many people saw, first, that all of the promises of the government were not carried out in more than 60 per cent of cases. .... That this contributed to the growth [of the FARC] in those two years, that is true. ${ }^{133}$.

\section{The State Left but the Population Stayed - Farclandia, 1998-2001}

The authority in these territories is the guerilla. The mayors can't work without talking to the guerilla about how their government should be. In practice, we are another government within a government. That is why we are requesting recognition as a belligerent force.

-FARC Commander Manuel Marulanda Vélez, San Vicente del Caguán, 1999134

Here nothing happens, there aren't violent deaths, one lives in peace. Half the members of the civil guard are [FARC] militants. ${ }^{135}$

Perhaps the most poignant demonstration of the FARC's legitimate authority in Caquetá was the population's support for the creation of a FARC demilitarized zone. In 1998 Colombian President Andres Pastrana ceded the FARC control over five municipalities in the departments of Caquetá and Meta. ${ }^{136}$ The FARC demilitarized zone comprised a 42,112-square mile zone (about the size of Switzerland) and took in five municipalities centered around San Vicente del Caguán in Caquetá, and about 100,000 or

\footnotetext{
${ }^{133}$ Peasant coca farmer in Caquetá; Ferro 2004

${ }^{134}$ The statement was made during an interview with journalist Mariela Guerrero of the magazine Alternativa. During the demilitarized zone period, many journalists came to San Vicente to observe and interview the FARC. Semana, January 1999, Tirofijo' se destapa

${ }^{135}$ Resident and employee at a beach bar on the River Caguán in San Vicente del Caguán; Soto-Trillo 2001: 53

${ }^{136}$ The five municipalities were San Vicente del Caguán in Caquetá, and La Macarena, Vistahermosa, Mesetas, and La Uribe in neighboring Meta
} 
so civilian inhabitants. ${ }^{137}$ The formation of a FARC demilitarized zone was merely a formal recognition of the FARC's consolidation of political and military control in the coca-growing western Amazon region during the previous decade. Despite the almost constant military incursions in Caquetá between 1986 and 1998, the FARC maintained effective domination of rural areas where coca was grown - particularly the lower Caguán, a circumscribed territory bordered by jungle on two sides and accessible only by river. ${ }^{138}$

The demilitarization in Caquetá and Meta lasted 28 months. It called for the complete evacuation of all state security forces including 2,000 military personnel and police, prosecutors, and judges, leaving the population under the control of some 3,000 FARC guerillas. ${ }^{139}$ Elected officials were allowed to remain in the zone, and the mayor of San Vicente del Caguán, José Emel Medina, chose to stay. ${ }^{140}$ In an interview with a Spanish journalist who visiting the zone in 1999, the mayor bragged that he was "the only mayor in Colombia to be without a bodyguard, and have a civil guard that is not armed, because there is no need." 141 In fact, while in the cities people feared that demilitarization would trigger a mass exodus from Caquetá and Meta, very few left. With the exception of a few ranchers from San Vicente, there was practically no evidence of civilian flight

\footnotetext{
${ }^{137}$ Currea-Lugo 2007: 114

${ }^{138}$ Jaramillo, et al. 1989: 246

${ }^{139}$ The military personnel included 1,500 soldiers with the Cazadores Battalion of the 2nd Mobil Brigade. Cambio 16, November 2, 1998, Despeje o despelote?, pp. 20-21

${ }^{140}$ Cambio 16, November 2, 1998, Despeje o despelote?, pp. 21

${ }^{141}$ Soto-Trillo 2001: 113
} 
leading up to or during the demilitarization. As one journalist puts it, there was nothing unusual in San Vicente del Caguán that summer except the weather. ${ }^{142}$

The supreme commander of the FARC, Manuel Marulanda Vélez (aka Tirofijo) stated that the zone would be 'a Colombia where we have democratic liberty for all.' ${ }^{\text {'43 }}$ Life in the zone was a far cry from Tirofijo's romantic aspirations. However, while the FARC did not take advantage of the demilitarization to demonstrate their commitment to democracy, they did demonstrate their capacity to govern effectively and support, or at least consent to support, the part of the population that did not rebel or flee. Local residents and visitors to Caquetá describe the demilitarized zone under the FARC as a time of calmness and continuity. If anything, the cessation of military incursions increased security. In fact, at the declaration of the demilitarization zone, the homicide rate declined from six to two per week according to an official with the local prosecutor's office. $^{144}$

The department of Caquetá had already become 'a country within a country' by 1998. ${ }^{145}$ A decade prior to the formation of the zone, the FARC created autonomous governance institutions in order to restore order in the wake of the coca boom. Those same institutions would continue to govern after the exit of the military. These included credit banks, courts, and arbitration centers in Cartagena de Chairá and other centers. They had already established tolls and fines for violations of public safety ordinances,

\footnotetext{
${ }^{142}$ Lozano Guillen, Carlos A (1998) San Vicente del Caguán, Lo único anormal es el clima, in VOZ November 1996 to December 1998

${ }^{143}$ Unedited interview with Tirofijo published in El Tiempo, June 1, 1999

${ }^{144}$ Cambio 16, November 2, 1998, Despeje o despelote?', p. 24

${ }^{145}$ Currea-Lugo 2007: 114
} 
and even issued stamped receipts as proof of payment. ${ }^{146}$ When the military exited, there was not chaos but rather order and continuity.

It was the FARC's capacity to autonomously maintain order that was the source of its legitimate authority in Caquetá. However, legitimate authority should not be confused with democracy. If the FARC was effective, it was because they identified and brutally punished threats to the social order. However, this was done without much of test of evidence and no public trial. ${ }^{147}$ What is more, the FARC mandated that those punished must provide the labor for public works while obligating farmers to supply machinery and merchants to supply capital. ${ }^{148}$ Nonetheless, while the constant threat of violence was oppressive, it was also effective in deterring delinquency and crime, something that the local communities observed and appreciated.

In fact, while there are no official crime statistics, observers report that the crime rate in El Caguán virtually ceased under the control of the FARC. Amnesty International reports that crime was so well controlled in the zone that foreign visitors could enter and leave with ease. They conclude that demilitarizing El Caguán resulted in a "three-year period of relative calm and economic prosperity." ${ }^{\prime 149}$ Indeed, despite the presence of an illegal economy, the FARC had "nevertheless been able to establish rudimentary social order within communities shunned by civil society and excluded from central government policies."

\footnotetext{
146 ibid

${ }^{147}$ Soto-Trillo 2001: 86

148 ibid: 103

${ }^{149}$ Amnesty International 2002: 5

${ }^{150}$ Mason, 2005: 42
} 
At the time of the formation of the demilitarized zone, the FARC was at the height of its military and political power. ${ }^{151}$ This explains the guerillas' success in bargaining for the demilitarized zone, and their ability to defend against military and paramilitary incursions. However, the peace process ended abruptly in 1999 when FARC leader Manuel Marulanda Vélez did not show up to the negotiating table. ${ }^{152}$ After the dissolution of the zone, the FARC's territorial control was once again threatened by two powerful enemies: the paramilitary organization United Self-Defense Forces of Colombia (AUC) and the state. In contrast to the ELN in Arauca, the FARC was more successful by far in protecting their territorial stronghold against armed rivals. However, after 2004, FARC control succumbed to the combined effects of an unprecedented state military attack, the decline of coca, and the forced displacement of the population by state security forces.

\section{The Paramilitary Challenge and Civilian Loyalty}

FARC dominance in coca-growing regions did not go unchallenged. Following the dissolution of the demilitarized zone in 2001, FARC territorial control was threatened by a powerful national alliance between a number of Colombian narcotics traffickers and the right-wing paramilitary organization United Self-Defense Forces of Colombia (AUC). The AUC ousted the FARC and the ELN from other parts of the country, including the oil-rich Magdalena Medio, Caribbean, and eastern plains regions. However, the FARC's symbiotic relations with civilians in the western Amazon proved impenetrable. The

${ }^{151}$ La Semana 834, 1998, Aquí Mando Yo,

${ }^{152}$ Ruiz 2001: 26 
paramilitaries never gained a foothold in Caquetá and Guaviare, historically the two most important coca-growing regions.

The United Self-Defense Forces of Colombia (AUC) targeted the coca-growing regions precisely because these were the areas where the insurgents had high civilian report and access to resources. To enter coca zones, the AUC forged alliances with a number of narcotics traffickers who had laundered their money in land and ranching enterprises in more economically integrated regions of Colombia. As rural elites, narcotics traffickers were targets for FARC kidnappings and extortions. In 1984, the narcotics traffickers issued a manifesto denouncing the guerillas. They hired private security forces and created the group Death to Kidnappers (MAS) to confront insurgent threats. ${ }^{153}$ Support from narcotics traffickers helped the paramilitaries gain control over parts of the Magdalena Medio and Caribbean regions northeast of the capital city of Bogotá. ${ }^{154}$ Therefore, when the AUC turned their sights toward the Western Amazon, they brought in narcotics traffickers as commanders of entire paramilitary bloques. ${ }^{155}$

In 1998, the paramilitaries began to increase their presence in Putumayo, Caquetá, and Guaviare, resulting in several military confrontations with the FARC during which peasants were killed in the crossfire. As part of their strategy, the paramilitaries targeted civilians. The leader of the cocaleros movement was dubbed a 'guerilla' and he was driven by threats into fleeing the zone, along with other community leaders. In the

\footnotetext{
153 Tickner, et al. 2011: 420

154 Medina 1990

${ }^{155}$ There were important internal divisions over control of the drug trafficking market, resulting in a division among traffickers between those who supported the paramilitaries and those who continued to collaborate with the FARC; Ávila 2011: 23
} 
first two months of 1998, 38 civilians were killed by paramilitaries in Puerto Asís, Putumayo alone. However, most of the local population did not flee in response to the violence, but chose to stay and protest. They denounced what they perceived to be a coalition between the paramilitaries and the state, and accused the army of providing the paramilitaries with 'blacklists' of local civilians to be targeted for collaborating with the insurgents. Of course they collaborated with the insurgents; the FARC had supplanted the rule of the state since 1984 . Once could not live in the zone without collaborating with the local authorities - the guerillas. ${ }^{156}$

In June of 1998, 500 peasants traveled to Bogotá to see President Ernesto Samper to denounce the activities of the paramilitaries in the Western Amazon region (Putumayo, Caquetá, and parts of Guaviare) and to condemn the complicity between paramilitaries and the army. In Putumayo, a committee called the 'Committee for the Defense of Life' was organized. They warned the government that if the state did not take action, the local communities would take matters into their own hands. Meanwhile, the massacres continued, including the collective murder of 28 peasants by paramilitaries in Putumayo and another 20 in Caquetá in 1999. ${ }^{157}$

However, the paramilitaries never gained a foothold in either department. The main factor that explains the failure of the paramilitaries to conquer any territory in Caquetá, Guaviare or Putumayo was that they were an outside force that could not find local allies. Loyalty toward the FARC was strong. Narcotics traffickers stood as the only potential allies because their relationship with the FARC was purely economic. Indeed, as

\footnotetext{
${ }^{156}$ Ramírez 2003

157 ibid
} 
rural elites, narcotics traffickers shared the political goals of the AUC in defending the status quo. However, by the 1990s narcotics traffickers purchasing coca in FARCcontrolled zones were not residents of the zones. What is more, even their merchant intermediaries had been evicted.

The FARC reacted to the narco-traffickers' participation in paramilitary campaigns in other regions by expelling the intermediary merchants or chichipatos who worked for the traffickers, and monopolizing local coca markets themselves. This was a strategy for avoiding a paramilitary infiltration into Caquetá and similar regions. As early as 1991, the FARC was purchasing coca from local farmers who complied by selling only to the FARC. ${ }^{158}$ The FARC continued to tax the sale of coca while assuming a direct role in the illicit commodity chain. ${ }^{159}$ The strategy coincided with a significant decline in public support for the FARC at the national level. However, the popularized image of the FARC as a drug 'cartel' did not resonate with farmers in Caquetá. ${ }^{160}$ Civilian support for the FARC was shaken but not destroyed by the FARC's strategic monopolization of markets:

There really there is a distortion; as far as I know, there does not exist a FARC cartel. I attest that they don't have crops, nor laboratories, nor landing strips. Their work is limited to collecting contributions for the use of landing strips, for the planes, for the kilos purchased that they sell and for the hectares of coca leaf cultivated. Contributions, as they call them; that have sustained them. But that they are directly involved in the trade of base,

\footnotetext{
158 The FARC has economic agreements with the cartels; however, there is no clear information on which cartel groups remained with the FARC and which joined the side of the paramilitaries at this time.

${ }^{159}$ Soto-Trillo 2001: 90; Ferro 2004: 22; Ferro and Uribe 2002: 98

${ }^{160}$ See Luis Alberto Vilamarín Pulido (2010) El Cartel de las Farc, CreateSpace Independent Publishing Platform
} 
in the trade of crystal [cocaine proper], not that I recall, not up to until now. ${ }^{161}$

They [FARC] as regulators of coca, they are tax collectors. I can give testimony that they are not direct cultivators of coca, and I can also say that they don't earn from coca outside of some taxes that they charge as much to the peasants per kilogram or per arroba of leaf according to the case. For example, I know that per kilogram the intermediary merchants get charged 20,000, 30,000 pesos by them [the FARC] for security services or for regulation of the flow of flights. ${ }^{162}$

Perhaps what is most interesting about these statements is that we know that the FARC was doing much more than taxing, and yet locals came to their defense. Perhaps this is because the FARC used their position as the sole purchaser of coca to benefit the coca farmers. The FARC began setting the price of coca well above the cost of production to ensure that families earned at least what they needed for subsistence. ${ }^{163}$ The insurgents then passed off the costs of the inflated prices to the narcotics traffickers who purchased coca from the FARC and whose only access to coca growers was the FARC. Indeed, the price of coca increased between July and October of 1999 from 1,300 to 2,300 pesos per kilo of coca paste. ${ }^{164}$

Finally, while the AUC never controlled significant territory nor populations in Caquetá, they did manage to win small niches of support in parts of Putumayo. In Putumayo, the presence of land-owning narcotics traffickers facilitated the entrance of the paramilitaries. However, the story of Puerto Asís, Putumayo, demonstrates the struggle of the paramilitaries to gain a foothold in coca-growing communities even where

\footnotetext{
${ }^{161}$ Resident of Caquetá; Ferro 2004

162 ibid

163 ibid

${ }^{164}$ ibid
} 
narcotics traffickers were available as allies. ${ }^{165}$ In 1991, the drug trafficker El Mexicano purchased a large farm he called La Azul in Puerto Asís which he turned into a coca plantation worked by local peasant labor. Initially, El Mexicano established a cooperative economic relationship with the FARC. The insurgents provided 24-hour protection for his farm, and he paid security rents. However, he soon began to pay some of his workers in drugs, causing a problem of drug addiction in Puerto Asís, a town of some 57,000 people. The FARC intervened, resulting in the death of two FARC leaders. The FARC retaliated by attacking El Mexicano’s property on numerous occasions between 1991 and 1992.

In 1993 El Mexicano joined up with two paramilitary groups seeking to form a stronghold in the coca-producing department. However, before any combat took place between the FARC and El Mexicano's paramilitary squads, the community of Puerto Asís stepped in and physically evicted El Mexicano. Indeed, in response to peasant protests and threats, El Mexicano and his paramilitary protectors left the region by plane under police protection. Later, the national paramilitary organization AUC returned to Putumayo and did manage to remain in the region with a few small bases of social support that were essentially islands in a sea of FARC-controlled territory. ${ }^{166}$

\section{Plan Patriota: the Demise of the FARC in Caquetá}

Although the guerilla committed numerous acts of violence against members of the civilian populations and persistently violated international humanitarian law (IHL) during its time in control of the $\mathrm{DMZ}$, the violence has increased significantly since the

\footnotetext{
${ }^{165}$ By the late 1990s, Putumayo surpassed Caquetá and Guaviare in total hectares of illicit coca crops.

${ }^{166}$ Author interview with Kyle Johnson, research associate with Corporación Nuevo Arco Iris, September 28, 2011, Bogotá, Colombia; state military incursions were in part a response to FARC aggression against military posts. On August 31, 1996, the guerillas took the military base at Las Delicias in Putumayo, killing 27 soldiers and taking another 60 hostage and on February 3, 1997, the FARC killed 16 soldiers in San Juanito, Meta.
} 
military retook the area, and the civilian population is being systematically targeted both by the security forces and their paramilitary allies and by the guerillas. ${ }^{167}$

Eventually the FARC's quasi-state control in Caquetá was undermined, and the FARC was driven out of town centers. It took a tremendous military effort that began in 2002 for the state to conquer the urban centers of Caquetá, and the FARC remains in control in most rural areas. What is more, government success in Caquetá was in no small part facilitated by a significant decline in coca cultivation after 2004 and the forced displacement of much of the rural population. The coca economy and the peasant sector were the foundations of the FARC's social order. Since 2004, the breakdown of FARC control provides further evidence of the FARC's effectiveness in delivering security and order. Without the FARC in command, Caquetá succumbed to increasing violence and crime. The state succeeded militarily, but civilian security declined as a result.

The FARC's record against the state is impressive. Indeed, the insurgents withstood an onslaught of military incursions against their territorial stronghold in southern Colombia during the months leading up to the creation of the demilitarized zone. ${ }^{168}$ The largest attack, Operation Destructor II, took place in October of 1997, and was an attempt to dislodge the FARC from Los Llanos de Yarí in Caquetá because the FARC leadership had reportedly set up central operations there. For three weeks, 3,000 military troops with air force support battled the FARC's security forces without gaining any ground. In response, the FARC inflicted a number of military losses on the state. On March 1, 1998, the FARC devastated a military battalion in Caquetá, killing 82 soldiers

\footnotetext{
${ }^{167}$ Amnesty International 2002: 2

168 ibid
} 
and taking 43 hostage. ${ }^{169}$ Again, on April 16, 1998 the FARC killed 31 military troops in Puerres, Nariño.

By 1998, it was clear that the Colombian state's military campaign had failed. The insurgents were too strong, and the policy was costly in terms of money, lives, and declining public support. Hence, Andrés Pastrana (1998-2002) built his presidential campaign on a promise to negotiate with insurgents. As promised, Pastrana created the demilitarized zone as a condition for talks with the FARC soon after his election in 1998. However, the peace talks began to fall apart almost as soon as they began. A major obstacle was that the state could not control the paramilitary groups that continued to wage war, attacking the FARC and their civilian supporters in other regions. ${ }^{170}$ The FARC lost confidence that the state would protect them after a demobilization. Indeed, the memory of the paramilitaries' political genocide of the Patriotic Union, the FARC's legal political party, was still fresh. ${ }^{171}$ Nonetheless, much of the Colombian public interpreted the FARC's abandoning of the process as evidence that the insurgents were not serious about demobilizing because war had become a profitable activity and the drug trade had supplanted political goals.

Following the termination of the Pastrana talks and the dissolution of the demilitarized zone, the Colombian government began investing immense resources in

\footnotetext{
${ }^{169}$ La Semana 834, 1998, Aquí Mando Yo

${ }^{170}$ Romero 2003

${ }^{171}$ The Patriotic Union was a legal political party created during the FARC's negotiations with President Belisario Betancur in the early 1980s. However, thousands of UP candidates and party militants were assassinated by paramilitary groups during the 1980s and 1990s; see Steven Dudley (2003) Walking Ghosts: Murder and Guerilla Politics in Colombia, Routledge.
} 
militarily reconquering the Western Amazon region. ${ }^{172}$ Under President Álvaro Uribe (2002-2010), Colombia launched Plan Patriota, a military campaign that targeted the FARC in their historic stronghold. Plan Patriota was the strongest military offensive in Colombian history and resulted in a permanent occupation by nearly 17,000 military troops in southern Colombia. ${ }^{173}$. Caquetá was the military target for phase II of Plan Patriota that began in late 2003.

Between 2004 and 2007, clashes between the FARC and the military increased dramatically in Caquetá, ending the FARC's seeming invulnerability in the region. ${ }^{174}$ Within the first 20 months of operations, the Colombian armed forces overtook 906 FARC camps. ${ }^{175}$ In addition, there were hundreds of successful captures and the defection of large numbers of FARC combatants including high level commanders, reducing FARC numbers from an estimated 20,000 in 2004 to 10,000 in $2009 .{ }^{176}$ In addition, the military implemented a campaign of forced displacement, uprooting large parts of the rural population and relocating them to town centers and cities, particularly Villavicencio in Meta. In Caquetá, the displacements coincided with a 'zero tolerance' policy against coca cultivation. Indeed, Colombian policy makers understood that undermining the FARC would require breaking the ties between coca farmers and insurgents. Breaking insurgent-civilian ties could have been done through development

\footnotetext{
172 Between 2000 and 2009, the size of the Colombian military nearly doubled to 500,000 soldiers, and the budget tripled to 12 billion pesos. Isacson and Poe 2009: 6; Bouvier 2007; Rabasa 2001

173 Pizarro 2003: 5; Echandía and Bechara 2006: 39; Isacson and Poe 2009

${ }^{174}$ Echandía 2008: 4

${ }^{175}$ Echandía and Bechara 2006: 40

${ }^{176}$ DeShazo, et al. 2007: 29
} 
initiatives that incorporated the peasant population. Instead, the ties were broken by removing coca and, where needed, removing the population.

Since 2004, the FARC has abandoned town centers and retreated to the safety of the jungles in Caquetá where they remain. ${ }^{177}$ Military attacks severely weakened the FARC and as a result the insurgents have mostly abandoned their alternative government mission to focus on maintaining strategic resource areas and corridors. ${ }^{178}$ As a result, after 2004, the FARC became increasingly estranged from their peasant social base. ${ }^{179}$ In fact, as a result of community dissolution and declining coca, many areas where the FARC previously had strong relations with civilians are now zones where the FARC acts as a predatory authority that rules through fear. The FARC's weapons of predatory authority include massacres, assassinations, and forced displacement of unarmed civilians. ${ }^{180}$ There were very few assassinations in Caquetá during the FARC demilitarization zone period but 95 civilians were killed by FARC in just the first seven months following the dissolution of the zone. Some of these civilians were killed as a result of two massacres carried out by the FARC in La Macarena and Vistahermosa, Meta. ${ }^{181}$ What is more, in the absence of the FARC, neo-paramilitary groups linked to organized crime began operations in Caquetá after 2004. Hence, while Colombian military forces undermined the FARC's proto-state in Caquetá, the state still has not

\footnotetext{
177 Echandía and Bechara 2006

178 ibid

${ }^{179}$ Guttiérrez and Giustozzi 2010

${ }^{180}$ Echandía and Bechara 2006: 45, 50

${ }^{181}$ Amnesty International 2002: 3, 19
} 
replaced FARC institutions with state institutions that can deliver security and protection to the civilian population.

\section{Conclusion}

Caquetá is emblematic of other peasant communities in the Western Amazon that were strongholds of the FARC and also areas of significant illicit drug cultivation during the 1980s and 1990s. Caquetá is also emblematic of peasant communities in places such as the Upper Huallaga Valley of Peru between 1985 and 2000 and in Taliban-controlled Afghanistan before 2001. ${ }^{182}$ In Colombia, Peru, and Afghanistan, the presence of illicit drug cultivation resulted in political abandonment and repression by the governments, or the international community in the case of Afghanistan. Because illicit commodities are by definition 'illegal,' the population sectors that participate in illicit production are assigned a criminal identity that essentially cuts off state protection and security. The result is an authority vacuum that insurgents capitalize on in order to access rents while building bases of popular support.

The symbiotic relationship between the FARC and the peasant communities of Caquetá, which formed the basis for legitimate authority, cannot be dismissed as a simple alignment of interest. In reality, their interests did not align. What the peasant colonizer wanted, more than anything, was to own private property. Meanwhile, the FARC was a Marxist-Leninist organization theoretically opposed to private property, and openly advocating for a collective land system. Where the peasant colonizer and the FARC found common ground was in the illicit economy: both actors wanted the economic gains

${ }^{182}$ McClintock 1988; Labrousse 2005; Felbab-Brown 2009 
offered by illicit cultivation, but without the disorder and insecurity that resulted from the absence of state institutions and presence of the state's military force. In short, illicitness created a space in which insurgents could construct authority based on consensus rather than coercion. 


\section{Chapter Seven \\ Conclusion}

How do licit and illicit commodities effect insurgent authority in relation to local populations? This dissertation addressed this question with a sub-national study of oil and illicit coca production in Colombia. Drugs and oil are frequently linked to conflict, though only a few studies analyze how these commodities shape territorial control and civilian support for insurgents. ${ }^{1}$ Among existing studies, the overwhelming conclusion is that insurgents are more predatory in the presence of illicit commodities. Jeremy Weinstein's theory suggests that, compared to oil, the accessibility of illicit drugs will result in more predatory insurgents. ${ }^{2}$ Likewise, Mary Kaldor argues that linkages to criminal networks explains the increase in insurgent violence toward civilians since 1990. ${ }^{3}$ In Colombia, law makers tend to assume the narcotization of the Colombian conflict and this is reflected in counterinsurgent policies that repress and exclude illicit farmers. ${ }^{4}$

The objective of this dissertation was to expose the shortcomings of existing arguments and propose an alternative that focuses on the role of the state. I started with the puzzling observation that in Colombia insurgents developed legitimate authority in communities with illicit coca production and exercised predatory authority in regions with oil production. To account for these outcomes, I argued that illicitness provokes a repressive state response that creates opportunities for insurgents to access rents by

\footnotetext{
${ }^{1}$ Collier et al. 2003; Ross 2003, 2004; Le Billion 2001

${ }^{2}$ Weinstein 2007

${ }^{3}$ Kaldor 1999

${ }^{4}$ Ehrenfeld 1992
} 
offering illicit producers public goods resulting in legitimate authority. In oil producing regions, insurgents exploit resources with the usual coercive methods and predatory authority follows from that strategy.

In preceding chapters I presented empirical evidence from Colombia to validate my arguments. This chapter concludes with a discussion of the findings, broader implications, and weaknesses of my research including generalizability to other conflict settings. First, I synthesis my key finding, namely politics matters. Indeed, the politics surrounding commodity production is as important to conflict dynamics as is any intrinsic quality of the commodity itself, including accessibility and lootability. Government policy defines civilian interactions with the state, which in turn shapes opportunities for insurgents to access resources by popular consent rather than coercion alone. Second, I explore some of the broader implications of my research for conflict studies including the resource curse, and the role of organizational factors. Finally, I address the weaknesses of my research and most especially the question of external validity. I briefly probe the generalizability of my argument with the cases of Peru, Bolivia, and Nigeria. I use these short case studies as a point of departure for future research.

\section{Synthesis of Research Findings}

In this section I summarize my core research finding that the politics surrounding resources matters for determining the nature of insurgent authority. Indeed, we cannot deduce insurgent behavior based solely on the type of resource because insurgent strategies are a response to both economic and political factors. In this way, my research offers some encouraging implications that indicate policy has a significant impact. There 
is, in other words, no such thing as a 'resource curse'. State interventions matter, and theoretically there is opportunity for states to more effectively intervene. However, at the same time states rarely exercise complete sovereignty over policy choices. The case of Colombia strongly demonstrates the power of external influence, particularly where globalized commodities come into play.

\section{The Politics of Commodity Production}

The foremost finding that comes out of my research is that insurgent economic strategies and resulting authority are shaped by the politics that surround resources. Indeed, while previous studies focus almost exclusively on the economic, I find that insurgents determine strategies for extracting resources based on both economic and political opportunity structures. Economic opportunity is a factor that governments cannot necessarily control. It is determined by which commodities are available in a territory, and whether they constitute lucrative and accessible 'war commodities' that insurgents can use to sustain themselves. More than any other factor, global demand dictates commodity production irrespective of state policies. No-where is the power of market supply and demand more clearly demonstrated than in Colombia where illicit drug cultivation continues despite thirty years of government repression.

However, while economic opportunity is perhaps beyond government control, political opportunity is directly determined by state policies that either protect, or repress and marginalize the communities that produce globalized commodities. In short, economic opportunity determines whether or not insurgents will extract resources, but it is political opportunity that determines the how in insurgent resource extraction including 
the use of coercion and the type of insurgent authority that follows. Governments play a central role in shaping the political opportunities that surround commodity production. Hence, in order to explain how resources effect insurgent authority, we must include in the analyses the political landscape. The literature on resources and conflict cannot omit the state as a critical variable, even where state capacity is weak.

Indeed, my research suggests that economic approaches that posit a straightforward link between commodity type and insurgent behavior should be restructured to take into account the political context. In fact, my findings suggest that the very same commodity would have a different effect on insurgency in a different political context. It is certainly not inevitable that drug production will result in durable and legitimate insurgent 'proto-states' as occurred in Colombia. Nor is it inevitable that oil will produce predatory contestation. In Colombia, the state made a political choice to protect oil through militarization and to repress coca with violent forced eradication policies.

Hence, my research can account for the variation in insurgent authority in response to similar resources. A comparison of the three Andean states that produce illicit drugs are a case in point. In Bolivia, the state oscillated between toleration and decriminalization of coca due to the unusual organizational capacity and political power of Bolivian coca farmers. As a result, no insurgent group has exercised authority in Bolivia's coca-growing regions. In contrast, in Peru the Shining Path exercised legitimate authority in the Upper Huallaga Valley during a period in which the Peruvian state repressed coca production. Of all the Andean states, Colombia has maintained the most 
repressive policies toward coca growers which allowed insurgents to maintain legitimate authority over extensive parts of Colombian territory for decades.

\section{The State and Policy Change}

If politics shapes insurgent authority, it follows that the state plays a central role in determining the politics that surround resources. Most studies of internal conflict omit the state as an important variable. Discounting the role of the state is theoretically defendable on the grounds that states are often absent or weak in areas where insurgents operate. ${ }^{5}$ However, in the context of lucrative commodity production and conflict, the state responds either deploying the military to protect frontier communities or to exclude and repress them. My research shows that the state's choice of policy is critical in shaping local outcomes. This is encouraging because it suggests that states can pursue more effective policies that reduce violence and work to undermine non-state authorities. At the same time, national governments rarely exercise complete sovereignty over policies in the realm of global commodity production.

If state policy matters, a critical question becomes what determines state policy? In Colombia, I find that the primary factor determining government policy toward coca regions was the criminalization of coca. Indeed, both coca and oil production amplified the insurgent threat to state power. Oil extraction and coca production similarly took place in frontier communities where insurgents had access to resources. However, oil was a primary source of government revenue, and the state responded to protect its resource base. Conversely, the Colombian government could not access illicit coca rents and so

\footnotetext{
${ }^{5}$ Fearon and Laitin (2003) argue that low state capacity is one condition that favors insurgency
} 
the state ended up repressing coca production and equating illicit economic activity with subversion.

Illicitness is not an intrinsic quality of resources, but a politically determined characteristic. Theoretically, the Colombian government could legalize or merely decriminalize coca production. After all, coca was produced in Bolivia, Peru, and parts of Colombia for centuries but was not an issue of law enforcement until the 1970s. Decriminalizing coca production would increase the policy options available to the Colombian government for incorporating coca-producing communities. Indeed, coca producers have sought a dialogue with the Colombian government for decades. ${ }^{6}$ However, decriminalization of drug production could bring severe economic sanctions against Colombia by the United States.

Hence, one secondary finding of my research is that international factors, in this case the United States, play a central role in shaping the local dynamics of conflict in countries like Colombia through effects on government policy. Oil and coca are globalized commodities that shape politics in foreign markets. Therefore, foreign governments or organizations often have their own security interests and can impose on policy outcomes in producer countries strictly limiting the scope of policy options.

In Colombia, the United States' interest in protecting oil contributed to the militarization of Arauca and the breakdown of cooperative relations between oil companies and the ELN. It also provided the ELN with a platform on which to construct a nationalist discourse around militarily targeting and exploiting the oil industry.

\footnotetext{
${ }^{6}$ Ramírez 2011
} 
Likewise, the United States' 'war on drugs' and the use of economic sanctions to pressure producer countries was central to the adoption of harsh and environmentally destructive eradication policies in coca growing regions. In this way, the United States played a central role in determining local conflict dynamics including the nature of insurgent authority, violence, and contestation.

In sum, my research findings indicate that state policy matters, and this is both encouraging and discouraging. On the on hand, if policies matter than state policies can be changed to produce better outcomes. On the other hand, policy change is problematic because national governments (in states prone to internal conflict) do not exercise full sovereignty over the policy-making process. In particular, when conflict coincides with global commodity production in natural resources and drugs, the influence of outside actors weighs heavily on policy responses. The exclusion of foreign influences is neither realistic nor desirable since foreign governments are a source of crucial economic assistance. However, external influence narrows the scope of policy options and reduces government accountability vis-à-vis the populations effected by conflict and commodity production. The way forward must include constructing space for local actors to participate in policy decisions that directly affect their communities.

\section{II. . The Implications for Conflict Studies}

My research findings have implications for the study of conflict and resources

more broadly. My work breaks with existing studies of resources and conflict by 'bringing the state in' with regards to the analysis of resources and conflict dynamics. Indeed, my work breaks with previous studies because the state is an omitted variable in 
the political economy of conflict literature. By emphasizing the role of the state, my research provides new insights on three lines of inquiry within conflict studies: the relationship between resources and conflict duration, the structure of conflict (contestation vs. sovereignty), and the debate between resources vs. organizational structure in determining insurgent interactions with civilians.

First, my research has implications for the study of resource effects on conflict duration. There is little evidence that the presence of lucrative resources accounts for the onset of conflict. Even the strongest proponents of so-called 'greed theory' find that most conflicts begin with political grievances. ${ }^{7}$ Nonetheless, there is a strong and robust correlation between the presence of lucrative resources and conflict duration. ${ }^{8} \mathrm{My}$ research supports this finding, and provides some insight into why illicit commodities in particular contribute to conflict duration. I find that state repression of illicit commodities leads to legitimate insurgent authority, which is durable because of the strong links between insurgents and civilians. Counterinsurgency is impeded by civilian support for insurgents. On the other hand, when insurgents exercise predatory authority, civilians are likely to collaborate with state forces. In Colombia, the state gained ground in regions with oil compared to regions where illicit drugs were produced.

The FARC operated in regions where the state repressed illicit cultivations, and the FARC had the strongest links with illicit drug producers. Not surprisingly, the FARC is also the most durable insurgency in the history of Latin America. The FARC's relationship with the illicit economy played a central role in the FARC's ability to endure

${ }^{7}$ Collier and Hoeffler 1999

${ }^{8}$ Ross 2003, 2004 
not merely because the FARC had access to a lucrative resource, but also because the FARC secured their continued access by exercising legitimate authority vis-à-vis the populations that produced illicit drugs. Indeed, from their stronghold in Caquetá, the FARC carried out numerous military attacks while defending their territorial domain. The FARC's authority was facilitated by government repression of local populations. Until 2004, the FARC supplanted the state's authority in areas south of the city of Bogotá. In order to undermine FARC control, the state pursued Plan Patriota, the most aggressive military offensive against insurgents in the history of Latin America. And even then, the Colombian government always controls town centers.

Second, my research findings also contribute to our understanding of contestation and violence in civil war. In a now classic study, Stathis Kalyvas finds that contested conflict zones are more violent places for civilians compared to zones where one armed actor exercises sovereignty. ${ }^{9}$ Kalyvas argues that this is because civilians will take advantage of contestation to settle vendettas by denouncing their rivals as collaborators with enemy forces resulting in violence toward the denounced. Contestation vs. sovereignty is the starting point for Kalyvas' analysis. My research provides insight for understanding why some regions are contested in the first place. States will militarily contest regions with valuable commodities-such as oil. The resulting contestation is heightened by civilian collaboration with state forces as a reaction to predatory insurgents.

\footnotetext{
${ }^{9}$ Kalyvas 2006; also see Metelits 2010
} 
Certainly, contestation was an outcome of predatory authority in Arauca, Colombia, which explains why Arauca was consumed by violence during the 1990s. Oil multinationals were quick to support right-wing paramilitaries that sought to undermine ELN control in Arauca by targeting the ELN's civilian support base. What is more, disaffected peasants formed a base of support for the FARC. According to local testimonies, the internal war between the FARC and the ELN in Arauca claimed more civilian lives than the struggle between the state and insurgents. Conversely, the case of Caquetá shows that where insurgent authority is legitimate armed rivals face obstacles to co-opting civilian support resulting in a more durable sovereignty. The FARC was the authority in Caquetá for nearly three decades.

Third, my research speaks to the debate between organizational discipline and resources as explanations for insurgent predation. With this study, I considered the effects of organizational discipline as an alternative theory. Specifically, I compare my arguments to those of Paul Staniland who says that organizational discipline explains how insurgents interact with civilians in a number of activities, including resource extraction. Staniland argues that more disciplined insurgents will use less violence regardless of the type of resource. ${ }^{10}$ My analysis of the FARC and the ELN somewhat supports Staniland's thesis since the ELN is the less disciplined and also more predatory organization. However, in oil rich regions the FARC is just as predatory. Only in areas of illicit production do we find evidence of a more disciplined FARC. In the end, my research suggests that the resources vs. organizations debate is limiting because

\footnotetext{
${ }^{10}$ Staniland 2012
} 
commodity production takes place in a particular political context and that context is the most important factor shaping insurgent strategy.

Indeed, the evidence from Colombia alone suggests that the presence of certain resources accounts for insurgent authority better than the insurgents' distinct organizational structures. However, when we move beyond Colombia we find that resource type alone doesn't explain much, since the presence of coca in other Andean states such as Peru and Bolivia did not produce the same kind of durable, legitimate authority that it did in Colombia. My research shows that state policy is an omitted third variable in this debate.

\section{External Validity and Future Research}

Finally, beyond the findings and implication, my research also raises questions that are starting points for future research. One important limitation of my in-case research design is that it does not address the question of external validity beyond Colombia though it was well-suited for evaluating the internal validity of my argument. Do my arguments explain insurgent authority in other conflict settings? Do we see different outcomes where state policies vary? There are important question for future research. Here, I explore the external validity of my arguments with brief case studies of coca production and insurgency in the Upper Huallaga Valley of Peru and in Bolivia, and the effects of oil extraction on insurgency in the Niger delta region of Nigeria.

First, Peru and Bolivia are the world's most important sources of illicit coca production. It wasn't until the 1980 s that Colombia began to significantly produce the drug. Historically, the Andean countries of Peru, Bolivia, and Colombia monopolize the 
international cocaine market. Given the geographic and cultural similarities to Colombia, and comparable experiences as illicit coca producers, Peru and Bolivia are important contrast cases for testing the effects of policy on insurgent strategies and relations with civilians. I explore some of the policy differences between the three states here, and discuss the effects of policy on insurgent activities to probe the validity of my argument about illicitness and government repression as a causal variable determining insurgent authority.

Bolivia is a critical case because it is relatively weak and underdevelopment compared to Colombia and has been involved in the cultivation of coca for longer. Yet, no insurgent groups operate in Bolivia. In Bolivia, indigenous communities that produce coca are well-organized and politically active. For most of the 1990s, the Bolivian government opted for a 'voluntary eradication' policy to address the problem of coca cultivation in the regions of Chapare and Los Yungas. Voluntary eradication meant the coca farmers could eradicate their fields in exchange for a payment from the government. Of course, the policy was ineffective because of built-in incentives to cultivate new coca fields. The net effect of voluntary eradication was zero. By 1997, the United States was threatening to decertify Bolivia. In 1998, Bolivia responded with Plan Dignidad, a militarized forced eradication plan based on a goal of zero coca. That goal was nearly achieved, but the cost was the political mobilization of the coca farmers by an emerging leader Juan Evo Morales Ayma. ${ }^{11}$

\footnotetext{
${ }^{11}$ Kurtz-Phalen 2005: 106
} 
Bolivia entered the $21^{\text {st }}$ century a country on the verge of civil war. The core conflict revolved around the political right of indigenous farmers to cultivate coca. In 2004, the cocaleros successfully pressured President Carlos Mesa to allow illicit cultivation. Soon after, Mesa resigned as did his successor. Both renouncing Presidents warned that war in Bolivia was emininent, and that Morales and the cocalero movement were the driving force. Evo Morales is an Aymara Indian from Chapara, Bolivia. Like most indigenous in Chapare, Morales cultivated coca. Morales' political party, Movement Toward Socialism (MAS), emerged in 1995 from the cocalero syndicates. There are six cocalero federations that have acted as de facto government institutions in the coca regions since the 1960s. They distributed land and resolved disputes. They also controlled and taxed coca sales at market locations. In 2002, Morales came in second in the Presidential election. In 2006, the indigenous grass-roots leader, leftist politician, and champion of coca farmers was elected President of Bolivia. ${ }^{12}$

When Evo Morales came to office he introduced reforms that appeased the threat of a cocalero rebellion. Morales' election marked the political integration of Bolivia's marginalized indigenous populations that cultivated coca. A Bolivian Congress once entirely dominated by an elite class of European lineage was infiltrated by Representatives from indigenous communities. Morales and his political allies in Congress opted for a new policy called 'Coca Si, Cocaina No'. The policy tolerated the cultivation of coca, but pledged to cooperate with the United States in stopping cocaine trafficking. Hence, with financial backing from President Hugo Chávez of Venezuela,

\footnotetext{
12 ibid: $104-105$
} 
Morales focused on developing the industrialization of coca for legal products such as medicine, tea, and even toothpaste. ${ }^{13}$ Thus far, it's not clear how effective such alternative policies will be in reducing cocaine trafficking. However, the threat of civil war in Bolivia has dissipated as a result of the political integration of cocaleros.

In contrast to Bolivia, Peru is a coca-producing country that did experience an insurgency between 1980 and 1995. What is more, the Peruvian Shining Path (Sendero Luminoso; SL) exercised legitimate authority in the Upper Huallaga Valley of Peru (UHV) where coca was produced in a manner remarkably similar to the FARC in Colombia. In the Upper Huallaga Valley indigenous communities have produced and consumed coca leaf for centuries. However, in the 1950s Colombian smugglers began purchasing coca from Peruvian producers to make base for processing cocaine. As a result, coca production became profitable and increased. By the mid-1980s the Peruvian Civil Guard estimated that between 60,000 to 100,000 families were growing coca in the UHV. ${ }^{14}$ The production of coca in Peru coincided with the arrival of the insurgent group Shining Path to the Upper Huallaga Valley in $1985 .{ }^{15}$

The Peruvian government's initial reaction to illicit coca production was repressive. Beginning in the 1970s, the United States began investing resources and pressuring the Peruvian government to address the problem of coca production. In 1978, Peruvian President Francisco Morales Bermúdez declared a state of emergency in the UHV and began to forcibly eradicate coca crops, confiscate the land, and arrest illicit

\footnotetext{
${ }^{13}$ Mullikin 2008

${ }^{14}$ Felbab-Brown 2009: 37

15 McClintock 1988: 128-129
} 
cultivators. In 1983, the Peruvian government sent in 450 trained official to manually eradicate illicit coca plants under the protection of the Rural Mobile Patrol Movement, a paramilitary force notorious for human rights abuses. ${ }^{16}$

As in Colombia, repressive state policies in Peru increased the legitimacy of insurgent authority in coca-growing regions. As Cynthia McClintock argues, "The US and Peruvian governments' anti-drug efforts... cemented an alliance between the coca growers and Sendero Luminoso which between 1986 and 1988 gained control of as much as 90 per cent of the countryside in Peru's cocalandia, the Huallaga Valley," ${ }^{17}$ By 1985 , the Shining Path was collecting a 5 per cent tax on coca sales and charging fees to traffickers. In exchange, SL protected facilities and airfields, attacked government eradication teams, and led efforts to block roads and create barriers so that eradication teams could not enter. In addition, SL used a portion of the illicit rents to provide social services, including building roads, schools, and health facilities. ${ }^{18}$ As a result, SL's support base increased to almost 100,000 active civilian supporters in the UHV. ${ }^{19}$ The Upper Huallaga Valley was the only Peruvian region in which SL obtained the support of farmers without resorting to excessive violence. In other parts of Peru, the insurgents' had a reputation for extreme brutality toward civilians. ${ }^{20}$

The relationship between state repression and support for the SL suggests the Peruvian case is similar to that of Colombia. However, unlike Colombia, Peruvian policy

\footnotetext{
${ }^{16}$ Felbab Brown 2009: 37-41

${ }^{17}$ McClintock 1988: 127-128

${ }^{18}$ Kent 1993

${ }^{19}$ Felbab Brown 2009: 41-47

${ }^{20}$ ibid: 50
} 
toward coca cultivation varied significantly. In Peru, military higher ups opposed the policy of forced eradication, and often worked to block eradication efforts in the UHV. Most of the forced eradication in the UHV took place when the army was evacuated from the zone between 1985 and $1989 .{ }^{21}$ During that time, support for the SL was at an alltime high. By the late 1980s, support for eradication was declining among the national political elite largely because it was ineffective. In 1989, President Garcia rejected the United States' offer of anti-drug aid aimed at eradication as did incoming President Fujimori in 1990. Fujimori argued that forced eradication decreased cooperation with the government and cocalero support was critical to the counterinsurgency effort. ${ }^{22}$

Consistent with my argument, civilian support for SL decreased as the government drew back on forced eradication in the UHV. After 1989, civilian collaboration with the military resumed, and the Shining Path resorted to violence to control the UHV. Insurgent brutality led to the formation of peasant self-defense groups called peasant patrols (rondas campesinas) of which there were 4,200 groups by 1993. In the UHV, the peasant patrols overlapped with cocalero organizations such as the Defense Front Against Coca Eradication in the Upper Huallaga Valley (FEDECAH) in opposition to the Shining Path. ${ }^{23}$ The Peruvian government began to incorporate coca producers by supporting the peasant patrols with material and logistical support. SL lost control in the countryside, and moved into urban areas. Dr. Abimael Gúzman, the infamous leader of

\footnotetext{
${ }^{21}$ McClintock (1988: 130) reports the most successful year was 1985 when 5,000 hectares of coca were destroyed

${ }^{22}$ McClintock 1988: 130-134; Felbab-Brown 2009: 50-55

${ }^{23}$ Starn 1995; Felbab-Brown 2009: 55-56
} 
the Shining Path, was captured in the capital city of Lima in 1992. By 1995, only SL splinter groups remained active. ${ }^{24}$

Finally, there is also evidence from beyond Colombia that oil results in predatory insurgencies. In part, finding a case of oil and conflict comparable to Colombia is problematic because most conflicts involving oil are secessionist wars, whereas in Colombia the ELN was exploiting oil resources to wage a war based on a much broader agenda. Nonetheless, the confluence of conflict and a mostly privatized oil industry in Nigeria provides some additional test of my argument. Nigeria gained independence in 1960 as nation divided into ethnically distinct territories with the administrative center in the North giving power to the Hausa-Fulani Muslim over Christian minorities in the south. ${ }^{25}$ Political struggles between north and south were exacerbated when the multinational Royal Dutch/Shell-BP discovered crude oil in the Niger Delta region of southeast Nigeria in 1956. There, oil was extracted with little regard for local environment, health, or development. Meanwhile, royalties flowed back to the Hausadominated federal government.

The power of foreign multinationals in Nigeria is similar to Colombia. Like Colombia, oil exploration, extraction, and infrastructure in Nigeria is controlled by foreign multinationals, but revenues are shared with the state-owned Nigerian National Petroleum Corporation (NNPC). Moreover, as in Colombia, oil royalties are a major source of revenue for the Nigerian government. However, Nigeria is even more reliant on

\footnotetext{
${ }^{24}$ Degregori 1997: 179

${ }^{25}$ Conflicts were resolved with repression. Nigeria was ruled by successive military leaders until 1999 when a weak democracy was established. Uche 2008: 122; Cayford 1996: 183; Sokolowski 2010: 272-273
} 
oil. Nigeria is a petro-state and oil royalties and taxes make up about 80 per cent of government revenue and 90 per cent of foreign exchange. ${ }^{26}$

Following the discovery of oil, Nigeria has faced a series of insurgent threats. In 1968 when the oil-rich Igbo state of southeastern Nigeria attempted to secede as the independent state of Biafra. The Biafra conflict ended by 1970, but the conflict over oil was unresolved. In 1990 the Movement for the Survival of the Ogoni People (MOSOP) emerged in response to the abuses of oil multinationals and the distribution of oil revenues in favor of the national government. By 1994, an extremely violent government military campaign had undermined MOSOP and eliminated most of the movement's leaders. ${ }^{27}$ And yet, only a few years later Nigeria's democratization incited new insurgent groups in the Niger Delta region after 1999. While several insurgencies are active. The most important is the Movement for the Emancipation of the Niger Delta (MEND).

MEND is a small insurgency with between 100 and 1000 active combatants in 2003. The insurgent group formed based on demands for greater local control of oil revenues extracted in the Delta Niger, a government military withdrawal, and release of MEND leaders. Not surprisingly, MEND's main source of revenue has been illegally taping the oil pipelines, kidnapping and extortion of oil companies and their employees, and threatening attacks on oil infrastructure to extract protection payments. Between 1999 and 2003, insurgent attacks on oil infrastructure cost 60 per cent of oil output due to damage to exploded pipelines and the spilling of 370,000 barrels of oil in the Niger

${ }^{26}$ Cayford 1996: 184

27 ibid: $184-192$ 
Delta. ${ }^{28}$ Between 1998 and 2003, there was four hundred vandalizations of company facilities per year with total oil losses reaching \$1 billion a year. The violence continued. In the first six months of 2006 alone, insurgents carried out 19 attacks on foreign oil companies in the Delta Niger region costing over $\$ 2.187$ billion in lost revenues, or 32 per cent of Nigeria's total revenue that year. ${ }^{29}$

Hence, based on the preliminary sketch, there is evidence that insurgent economic strategies in Nigeria vis-à-vis the oil sector parallel the high cost, coercive strategy that we find in Colombia. What is more, the result is very much a predatory type of authority. Despite the high population density of the Delta Niger region (by far the most densely populated region in Africa), MEND was only able to recruit a small number of combatants. The exact number of men in arms is unknown, but the most liberal assessment puts it at less than 1,000. What is more, there is no evidence that MEND is providing public goods to local communities as part of their economic strategy, nor forging cooperative relations with oil multinationals even though their stated goal is not to drive the companies out but rather to claim a larger share of oil royalties for the communities in which oil is extracted.

However, while insurgent activities is consistent with my argument, the response of the Nigerian government was limited to military protection, with little effort to politically incorporate the local population. As in Colombia, the Nigerian government deployed the military to protect oil installations. Further, protection of military installations was logistically and financially supported by the United States, as it was in

\footnotetext{
${ }^{28}$ Banks and Sokolowski 2010: 274-276; Watts 2008: 4

${ }^{29}$ Watts 2008: 6
} 
Colombia. ${ }^{30}$ Albeit, Nigeria's military response was much more violent than in Colombia because the military institution is less disciplined and hardly controlled by democratically elected leaders. ${ }^{31}$

However, after 50 years of conflict, there has been little effort by the Nigerian national government to politically integrate the Niger Delta region despite the constant threat of insurgency. Nigeria directs only $17 \%$ of national oil revenue to the nine Delta states, a region with the highest population density in the world resulting in about 27 million people occupying approximately 27,000 square miles. ${ }^{32}$ The differences between Nigeria and Colombia with respect to oil and conflict suggest that dynamics might been different between relatively developed and so-called 'predatory' states. Indeed, in Nigeria the state lacks autonomy from the ethnic group that controls the central government. Banks and Skolowski explain, in Nigeria “...political leaders continue adhere to a politics of identity between ethnic factions, military institutions, and the regime. The government's construct is based on clientelism, rent seeking, and disbursement of largesse mostly to themselves. ${ }^{33}$

In sum, the cases of Bolivia and Peru provide a good contrast to Colombia's unrelenting repressive policies vis-à-vis coca. In Peru, policy has oscillated and policy changes coincide with the rise and fall of the Shining Path's legitimate authority in the

\footnotetext{
${ }^{30}$ Since 2003, the U.S. has invested millions in an African Coastal and Border Security Program and a Trans Saharan Counter-Terrorism Initiative all with the expressed purpose of defending oil production. The United States African Central Command (AFRICOM) maintains a significant presence in the region comparable to the activities of U.S. Southern Command (SOUTHCOM) in Colombia; Banks and Sokolowski 2010: 276

${ }^{31}$ Watts 2004: 14-15

${ }^{32}$ Banks and Sokolwski 2010: 279

${ }^{33}$ 2010: 278
} 
Upper Huallaga Valley. In Bolivia, the government's softer approach of voluntary eradication and toleration of coca cultivation under President Morales has assuaged radical forces in the countryside through political integration of indigenous communities. Finally, In Nigeria, it's clear that the presence of oil exacerbating pre-existing conflicts. There, the state deployed the military to protect their oil interests in the Delta Niger region as predicted. However, the Nigerian state has made little effort to politically incorporate the populations that occupy the zones where oil in extracted. Nigeria's different policies highlight the importance of institutional capacity as perhaps a scope condition for my arguments.

\section{Conclusion}

The findings of this research suggest that states plays a critical and under-studied role in determining how insurgents interact with resources and civilian populations. In this way, my research attempts to move beyond the 'resource curse' argument that assumes a linear relationship between the type of resource and insurgent predation. I find that insurgents sometimes construct legitimate authority based on popular consent in the presence of illicit resources that are being repressed by the state. Here, the political context shapes opportunities for cooperative rent-seeking rather than the commodity itself. Conversely, predatory authority based on coercion often results where lucrative natural resources are produced, since states will deploy protection and public goods to defend the state's interests. Hence, interactions between the state and civilians shape the politics that surround commodity production, and insurgents react to distinct political opportunities with different strategies. 
My research has important implications for the study of conflict and resources that I discussed in this chapter. It contributes new insights on the duration of conflict, and the spatial distribution of contested vs. sovereign territories. My research also contributes to our understanding of the role of organizations in determining insurgent interactions with resources. I find that in Colombia, organizational discipline cannot account for interregional variation in FARC and ELN economic strategies and insurgent authority. Rather, FARC and ELN strategies correlate with the presence of illicit or licit resources.

Finally, my research has weaknesses that should be explored as part of a future research agenda. The sub-national two case comparison that I present with this dissertation validates the internal logic of my argument. However, this dissertation offers only a modest test of the external validity of my argument. The brief analyses of Peru, Bolivia, and Nigeria suggest that my arguments could also explain other cases, but with limitations. Specifically, I find that the case of Nigeria does not entirely conform to my predictions. In fact, events in Nigeria indicate that weaker states might respond differently to licit resources because the central government lacks autonomy and is itself a predatory authority. Nigeria is a good starting point for future research. 
Appendices 
Appendix A

Political Map of Colombia ${ }^{1}$

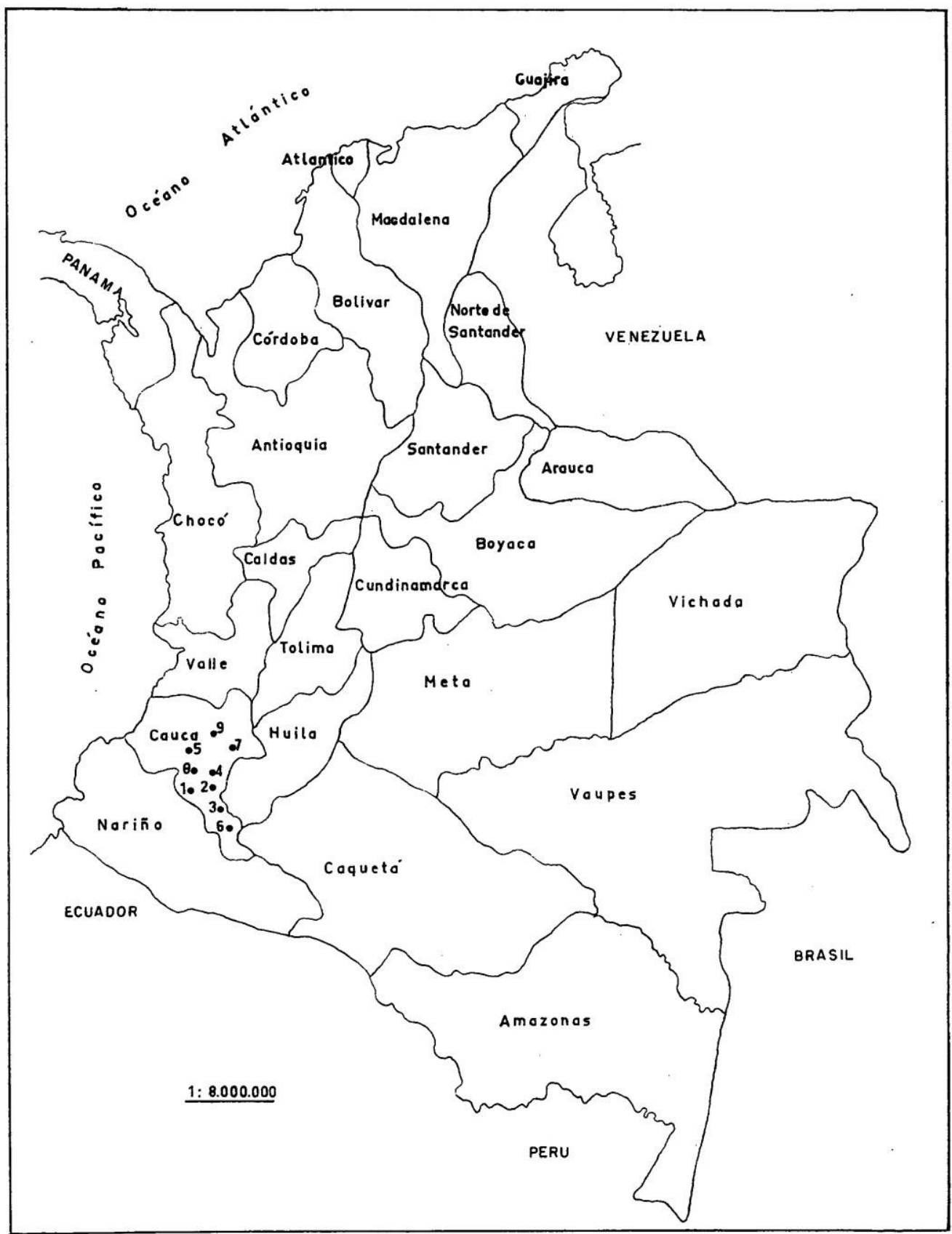

${ }^{1}$ Source: United Nations Office on Drugs and Crime (UNODC). Retrieved online:

http://www.unodc.org/unodc/en/data-and-analysis/bulletin/bulletin_1961-01-01_1_page002.html 


\section{Appendix B \\ FARC and ELN Strongholds in Colombia ${ }^{1}$}

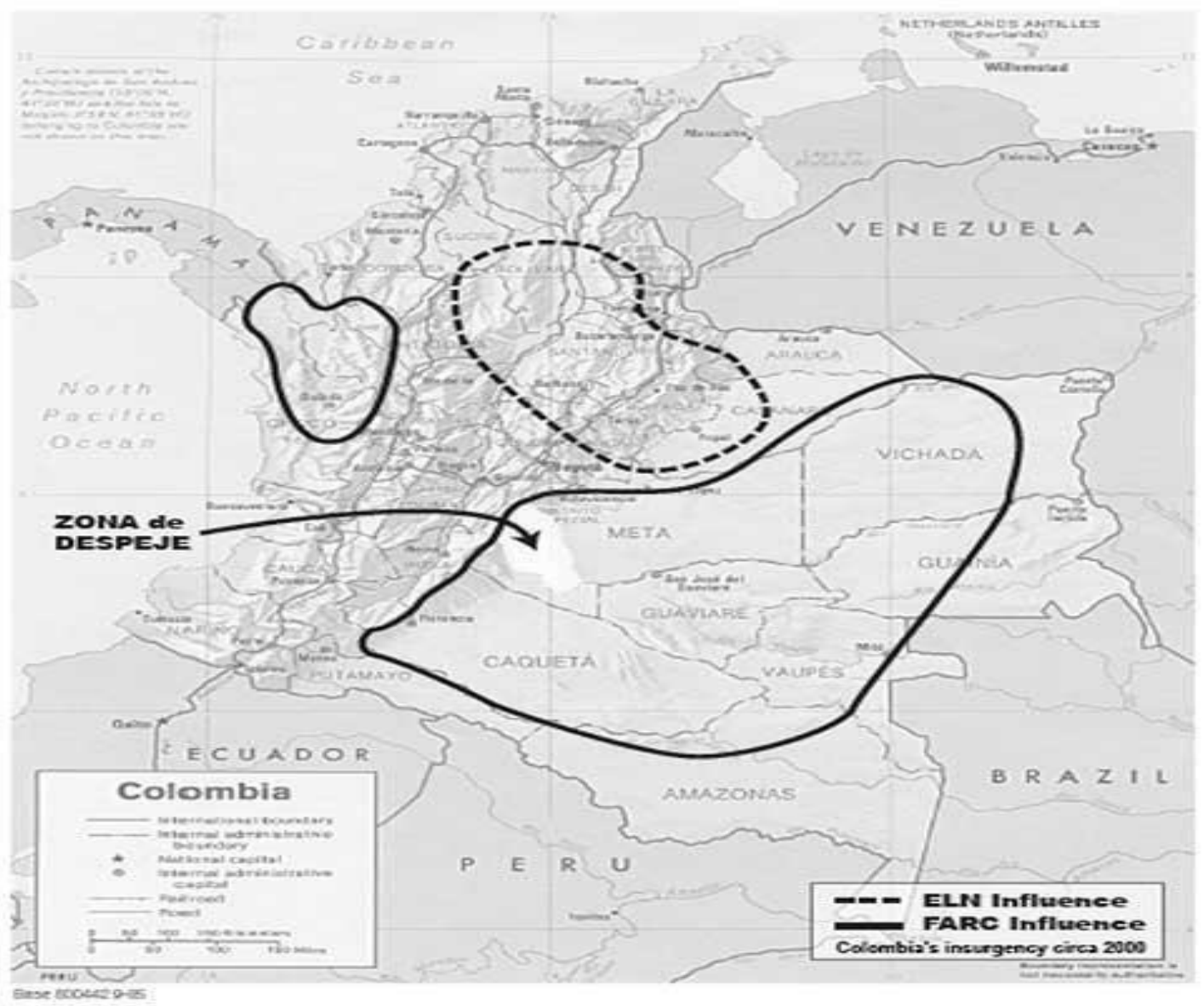

\footnotetext{
${ }^{1}$ Marks, Thomas A. (2011) A Model Counterinsurgency: Uribe's Colombia (2002-2006) vs FARC, Map based on United States Army data: http://usacac.army.mil/cac2/call/docs/11-15/ch_6.asp. The map indicates the FARC's zona
} 
Appendix C

Map of Coca Cultivation in Colombia, 2000-2004 ${ }^{1}$

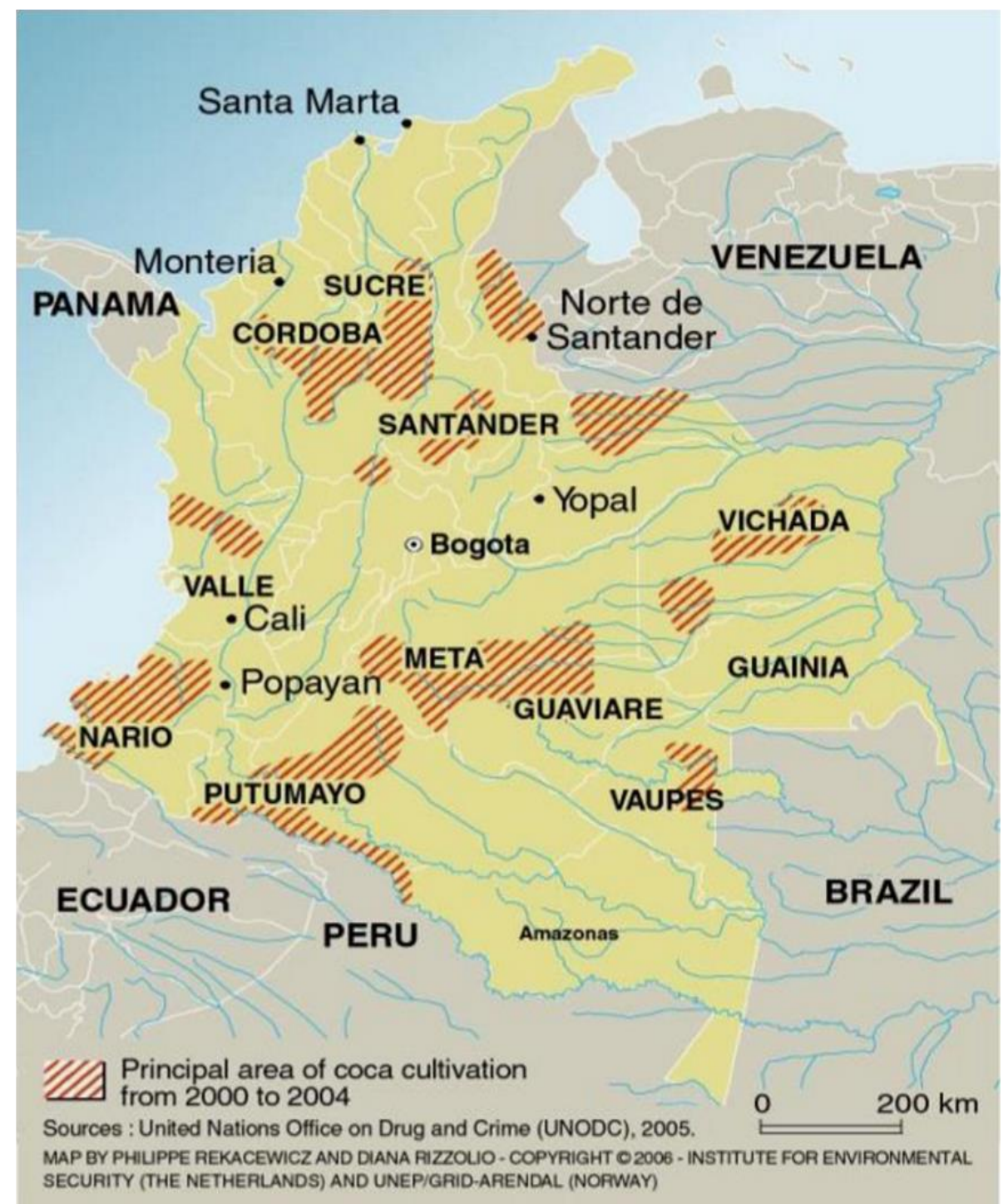

${ }^{1}$ United Nations Office on Drugs and Crime (UNODC 2005) 
Appendix D

Location of Oil Extraction and Pipelines in Colombia ${ }^{770}$

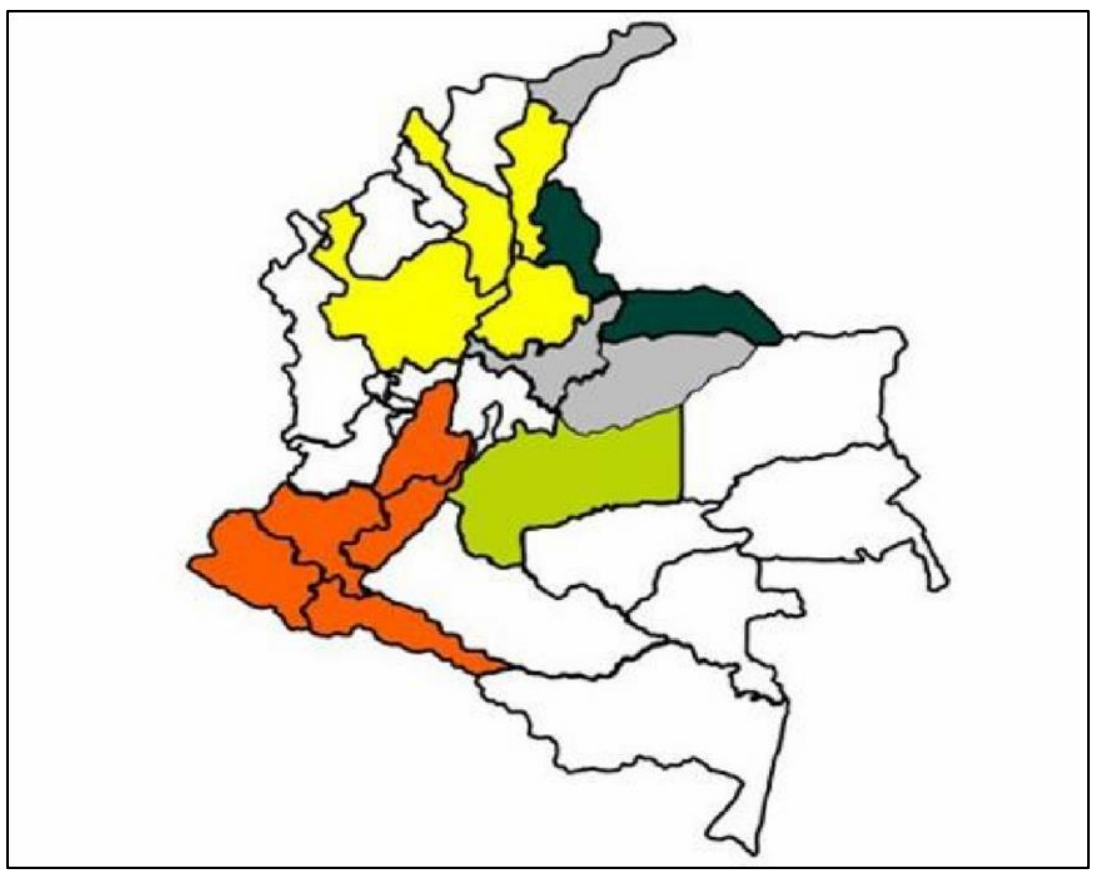

$\begin{array}{llrr}\text { Region } & \text { Departments } & \text { Production } & \% \\ \text { Center } & \text { Meta } & 148.5 & 29.5 \\ \text { Northeast } & \text { Casanare, Boyacá } & 128.4 & 25.5 \\ \text { Magdalena } & & & \\ \text { Medio } & \text { Santander, Cesar, Bolívar, Antioquia } & 77.2 & 15.3 \\ \text { Orinoco } & \text { North Santander } & 72.7 & 14.4 \\ & \text { Putumayo, Nariño, Cauca, Huila, } & & \\ \text { South } & \text { Tolima } & 68.6 & 13.6 \\ \text { Other } & & 8.8 & 1.7\end{array}$

${ }^{770}$ Source: Ecopetrol; http://www.ecopetrol.com.co/contenido.aspx?catID=376\&conID=43160 
Bibliography

Amnesty International (2002) San Vicente del Caguán after the Breakdown of the Peace Talks: A Community Abandoned. Retrieved online: http://www.amnesty.org

Angrist, Joshua D. and Adriana D. Kugler (2005) Rural Windfall or a New Resource Curse? Coca, Income, and Civil Conflict in Colombia, National Bureau of Economic Research (NBER) Working Paper No. 11219: http://www.nber.org/papers/w11219

Anthony, Robert W, Barry Crane, and Stephen F. Hanson (2000) Deterrence Effects and Peru's Force-Down/Shoot Down Policy: Lessons Learned for Counter-Cocaine Interdiction Operations. Alexandria, VA: Institute for Defense Analyses

Arenas, Jaime (1971) ELN, La guerrilla por dentro, Bogotá: Icono Editorial Ltda.

Arenas, Jacobo (1985) Cese el Fuego, una historia política de las FARC, Bogotá, Colombia: Editorial La Oveja Negra Ltda.

Arjona, Ana and Stathis Kalyvas (2009) Rebelling Against Rebellion: Comparing Insurgent and Counterinsurgent Recruitment, Centre for Research on Inequality, Human Security, and Ethnicity, prepared for the Workshop Mobilisation for Political Violence, What do We Know?, March 17-18, 2009

Ávila Martínez, Ariel Fernando (2011) Bloque Oriental, la nueva forma de operar y el vacío de poder, De la victoria a la derrota, in Medina Gallego, Carlos, FARC-EP flujos y reflujos: la guerra en las regiones, Bogotá: Universidad Nacional de Colombia

Ayling, Julie (2005) Conscription in the War on Drugs: Recent Reforms to the U.S. Drug Certification Process, in International Journal of Drug Policy, 16

Bakonyi, Jutta and Kirsti Stuvøy (2005) Violence \& Social Order Beyond the State: Somalia \& Angola, in Review of African Political Economy No.104/5, pp. 359-382

Banks, Catherin M. and John A. Sokolowski, Modeling the Niger Delta Insurgency, in The Social Science Journal 47, pp. 271-293, available online: www.sciencedirect.com

Bejarano, Jesús Antonio (1997) Violence, security and economic growth in Colombia, 19851995, in Colombian Economic Journal, Vol. 1(1), pp. 36-58

Berg-Schlosser, Dirk, Gisèle De Meur, Benoît Rihoux, and Charles C. Ragin (2009)

Configurational Comparative Methods in Qualitative Comparative Analysis (QCA) and Related Techniques, SAGE 
Bergquist, Charles, Ricardo Peñaranda, and Sánchez Gonzálo (2001) Violence in Colombia, 1990-2000: Waging War and Negotiating Peace, Scholarly Resources Books

Borrero Mansilla, Armando (2004) El Conflicto Armado Interno, Los Cultivos Ilícitos y la Gobernalidad Local. Revista Opera 4(004): 285-307

Bouvier, Virginia M. (2007) New Hopes for Negotiated Solutions in Colombia. United States Institute for Peace Working Paper. Retrieved online: www.usip.org/files/resources/Sept2007.pdf

Brain, Richard A. and Keith R. Solomon (2009) Comparison of the Hazards Posed to Amphibians by the Glyphosate Spray Control Program Versus the Chemical and Physical Activities of Coca Production in Colombia, in Journal of Toxicology and Environmental Health, Vol. 72(15-16), pp. 937-948

Braun, Herbert (1986) The Assassination of Gaitan: Public Life and Urban Violence in Colombia, University of Wisconsin Press

Brittain, James J. (2010) Revolutionary Social Change in Colombia: The Origin and Direction of the FARC-EP, Pluto Press

Bulmer-Thomas, Victor (2003) The Economic History of Latin America since Independence, Cambridge University Press; 2 edition

Cayford, Steven (1996) The Ogoni Uprising: Oil, Human Rights, and a Democratic Alternative in Nigeria, in Africa Today, 43(2), Conflict and Conflict Resolution in Africa, pp. 183-197

Célis, Luis (2010) Ejército de Liberación Nacional, Una aproximación a sus dinámicas sociales y comunitarias. Unpublished document prepared for the Historic Memory Project. Provided to author by Luis Celis in Bogotá, Colombia, November 2011

Chouvy, Pierre-Arnaud (2010) Opium: Uncovering the Politics of the Poppy, Harvard University Press

Collier, Paul, V. L Elliott, Havard Hegre, Anke Hoeffler, Marta Reynal-Querol, and Nicholas Sambanis (2003) Breaking the conflict trap : civil war and development policy, Vol. 1, A World Bank Policy Research Report

Collier, Paul and Anke Hoeffler (2005) Resource Rents, Governance, and Conflict, in Journal of Conflict Resolution, Vol. 49(4), pp. 625-633

Collier, Paul (2010) The Political Economy of Natural Resources, in Social Research, Vol. 77(4), pp. 1105-1132 
Contreras Tiguaque, Camilo Arturo (2010) Cultura política de un grupo de jóvenes que vivió en San Vicente del Caguán durante la zona de distensión (1998 - 2002), Master's Thesis in Political Science and International Relations, Pontificia Universidad Javeriana: http://repository.javeriana.edu.co/handle/10554/1390

Cornell, Svant E. (2005) The Interaction of Narcotics and Conflict, in Journal of Peace Research, 42(6), pp. 751-760

Cornell, Svant E. (2007) Narcotics and Armed Conflict: Interaction and Implications, in Studies in Conflict \& Terrorism, 30, pp. 207-227

Cramer, Christopher (2002) Homo economicus Goes to War: Methodological Individualism, Rational Choice and the Political Economy of War', in World Development 30(11): 1845-64.

Crandall, Russell (2001) Explicit Narcotization: U.S. Policy Toward Colombia During the Samper Administration, in Latin American Politics and Society, Vil 43(3), pp. 95-120

Cubides, Fernando (2004) Burocracias Armadas. Bogotá: Grupo Editorial Norman

Currea-Lugo, Víctor de (2007) Poder y Guerrillas en América Latina, Una mirada a la historia del guerrillero de a pie, Spain: Sepha

Degregori, Carlos Iván (1997) After the Fall of Abimael Guzmán, The Limits of Sendero Luminoso, in Cameron, Maxwell, Philip Mauceri, and Cynthia McClintock, The Peruvian Lybrinth:Polity, Society, Economy, The Pennsylvania State University

DeShazo, Peter, Tanya Primiani and Phillip McLean (2007) Back from the Brink, Evaluating Progress in Colombia, 1999-2007. A Report of the Americas Program, Center for Strategic and International Studies

DeShazo, Peter, Phillip McLean and Johanna Mendelson Forman (2009) Assessment of the Government of Colombia Project: Plan de Consolidación Integral de la Macarena (PCIM). Report for the Center for Strategic and International Studies (CSIS), April 22, 2009

Díaz, Ana María and Fabio Sánchez (2004) A Geography of Illicit Crops (Coca Leaf) and Armed Conflict in Colombia, CEDE Universidad de los Andes, Crisis States Programmes, Development Research Centre: http://eprints.1se.ac.uk/28213/1/wp47.pdf

Dion, Michelle L, and Catherine Russler (2008) Eradication Efforts, the State, Displacement and Poverty: Explaining Coca Cultivation in Colombia during Plan Colombia, in Journal of Latin American Studies, Vol. 40 (3), pp. 399-421 
Dishman, Chris (2001) Terrorism, Crime, and Transformation, in Studies in Conflict \& Terrorism, 24(1), pp. 43-58

Dudley, Steven and Mario Murrillo (1998) Oil in a time of war, NACLA Report on the Americas 31(5), pp. 42-46.

Duncan, Gustavo (2006) Los Señores de la Guerra, de paramilitares, mafiosos y autodefensas en Colombia, Editorial Planeta Colombiana

Dunning, Thad and Leslie Wirpsa (2004) Oil and the political economy of conflict in Colombia and beyond: a linkages approach, in Geopolitics, Vol. 9(1) pp. 81 - 108

Dube, Oeindrila and Juan F. Vargas (2006) Commodity Price Shocks and Civil Conflict: Evidence From Colombia, Centro de Recursos para el Análisis del Conflict (CERAC). Online: http://www.cerac.org.co/assets/pdf/Other\%20publications/CERAC_WP_2.pdf

Echandía Castilla, Camilo (1999) El conflicto armado y las manifestaciones de violencia en las regiones de Colombia, Presidencia de la Republica de Colombia, Oficina del Alto Comisionado para la Paz, Observatorio de Violencia; $1^{\text {st }}$ edition

Echandía Castilla, Camilo (2008) El fin de la invulnerabilidad de las FARC. El estado actual del conflicto armado en Colombia, in Nueva Sociedad, No. 217, pp. 4-13

Echandía Castilla, Camilo, and Eduardo Bechara Gómez (2006) Conduct of the Guerilla During the Uribe Vélez Government: Of the Logic of Territorial Control to the Logic of Strategic Control, in Análisis Político, Vol. 19(57), pp. 31-54

Ehrenfeld, Rachel (1992) Narcoterrorism, New York: Basic Books

Espinosa, Nicolás (2000) El despeje dos años después: En búsqueda de la experiencia del experimento. Causas, condiciones y perspectivas, La Macarena: studio de caso, in Revista Colombiana de Sociología, Vol. V(2)

Espinosa, Nicolás (2010) Política de Vida y Muerte: etnografía de la violencia diaria en la Sierra de la Macarena, Bogotá: Instituto Colombiano de Antropología e Historia (ICANH)

Fabienne, Peter (2010) Political Legitimacy, in Zalta, Edward N. (ed.), The Stanford Encyclopedia of Philosophy (Summer 2010 Edition)

Farrell, Graham and John Thorne (2004) Where have all the flowers gone?: evaluation of the Taliban Crackdown against opium poppy cultivation in Afghanistan, in International Journal of Drug Policy, 16(2), pp. 81-91 
Fearon, James D. and David D. Laitin (2003) Ethnicity, Insurgency, and Civil War, in American Political Science Review, 97(1), pp. 75-90

Fearon, James D. (2004) Why Do Some Civil Wars Last So Much Longer Than Others?" in Journal of Peace Research, 41(3), pp. 275-301

Felbab-Brown, Vanda (2009) Shooting Up: Counterinsurgency and the War on Drugs, Brookings Press

Ferro Medina, Juan Guillermo and Graciela Uribe Ramón (2002) El orden de la Guerra; las FARC-ep, entre la organización y la política, Bogotá: Centro editorial javeriano, CEJA

Ferro, Juan Guillermo (2004) Las FARC y su relación con la coca en el sur de Colombia: testimonies de colonos y guerrilleros, in Sánchez, Gonzalo and Eric Lairs (eds) Violencias y estrategias colectivas en la región andina: Bolivia, Colombia, Ecuador, Perú y Venezuela, Bogotá: Instituto Francés de Estudios Anindos (IFEA), Instituto de Estudios Políticos y Relaciones Internacionales (IEPRI) y Grupo Edit. Norma

Fukumi, Sayaka (2008) Cocaine Trafficking in Latin America, EU and US Policy Responses, Ashgate Publishing Company, Burlington VT

Fumerton, Mario (2001) Rondas Campesinas in the Peruvian Civil War: Peasant Self-Defense Organizations in Ayacucho, in Bulletin of Latin American Research, 20(4), pp. 470-497

George, Alexander L., and Andrew Bennett (2005) Case Studies and Theory Development in the Social Sciences, MIT Press, $4^{\text {th }}$ Edition

González-Arias, José J (1998) Cultivos Ilicitos, Colonizacion y Revuelta de Raspachines in Revista Foro 35

González, José Jairo (1986) El Caquetá: de la colonización a la guerra y a la rehabilitación, Universidad de la Amazonia, Florencia

González, José Jairo and Roberto Ramírez (1975) La Colonización en el Caquetá: el caso de la colonización cordillerana sur, Florencia

Gonzáles Manrique, José E (1990) Perú: Sendero Luminoso en el Valle de la Coca, in García Sayán, Diego (ed.), Coca, Cocaína y Narcotráfico, Laberinto en los Andes, Comisión Andina de Juristas, pp. 207- 223

Gootenberg, Paul (2008) Andean Cocaine: The Making of a Global Drug, The University of North Carolina Press

Guáqueta, Alexandra (2003) The Colombian Conflict: Political and Economic Dimensions, in Ballentine, Karen and Jake Sherman (eds.), The Political Economy of Armed Conflict: Beyond Greed and Grievance, pp. 73- 107, Lynn Rienner Publishers 
Guevara, Ernesto Che (2013) Guerilla Warfare, Create Space Independent Publishing Platform

Gutiérrez Lemus, Omar (2004) La oposición regional a las negociaciones con el Eln, in Análisis Político No. 52, IEPRI-Universidad Nacional, pp. 36-40

Gutiérrez Sanín, Francisco (2004) 'Criminal rebels? A discussion of civil war and criminality from the Colombian experience', in Politics and Society 32(2): 257-85.

Gutiérrez Sanín, Francisco (2006) Internal Conflict, Terrorism and Crime in Colombia, in Journal of International Development, 18, pp. 137-150

Gutiérrez Sanín, Francisco (2008) Telling the Difference: Guerillas and Paramilitaries in the Colombian War, in Politics Society, Vol. 36 (3)

Gutiérrez Sanín, Francisco and Antonio Giustozzi (2010) Networks and armies: structuring rebellion in Colombia and Afghanistan, in Studies in conflict \& terrorism, 33 (9). pp. 836-853

Hall, Peter (2003) Alligning Ontology and Methodology in Comparative Politics, in Mahoney, James, and Dietrich Rueschemeyer (eds), Comparative Historical Analysis in The Social Sciences, pp. 373-406, Cambridge: Cambridge University Press

Harnecker, Marta (1988) ELN: Unidad que multiplica. Entrevista a dirigentes máximos de la Unión Camilista - Ejército de Liberación Nacional, sobre la historia del ELN, Ecuador, Quimera Ediciones

Henderson, James D. (1985) When Colombia Bled, University of Alabama Press

Hinojosa, Victor J. and Aníbal Pérez-Liñán (2003) Presidential Impeachment and the Politics of Survival: The Case of Colombia, pp. 65-81 in Baumgartner, Jody C. and Naoko Kada (eds) Checking Executive Power, Presidential Impeachment in Comparative Perspective, Praeger Publishers

Hironaka, Ann (2005) Neverending Wars: The International Community, Weak States, and the Perpetuation of Civil War, Harvard University Press

Hoffman, Danny (2007) The Meaning of a Militia: Understanding the Civil Defense Forces of Sierra Leone, in African Affairs 106(425), pp. 639-662

Hoffman, Kelly, and Miguel Angel Centeno (2003) The Lopsided Continent: Inequality in Latin America, in Annual Review of Sociology, Vol. 29, pp. 363-390

Holmes, Jennifer S., Sheila Amin Gutiérrez de Piñeres, and Kevin M. Curtin (2008) Drugs, Violence, and Development in Colombia:A Department-Level Analysis, in Project MUSE, Vol. 48(3), pp. 157-184, Online: http://ggs.gmu.edu/People/Curtin/LAPSFinal.pdf 
Holmes, Jennifer S., Sheila Amin Gutiérrez de Piñeres, and Kevin M. Curtin (2009) Guns, Drugs, and Development in Colombia, University of Texas Press

Holmes, Jennifer S., and Sheila Amin Gutiérrez de Piñeres (2012) Violence and Sectoral Development in Colombia, in Ascher, William and Natalia S. Mirovitskaya (eds), Economic Development Strategies and the Evolution of Violence in Latin America, pp. 95-124, Palgrave Macmillan

Humphreys, Macartan and Jeremy M. Weinstein (2006) Handling and Manhandling Civilians in Civil War, in American Political Science Review, Vol. 100(3), pp. 429-447

Hutchinson, Steven and Pat O'Malley (2007) A Crime-Terror Nexus? Thinking on Some of the Links between Terrorism and Criminality, in Studies in Conflict and Terrorism, 30(12), pp. 1095-1107

Immigration and Refugee Board of Canada, 2008, Colombia: The Recruitment Methods of the Revolutionary Armed Forces of Colombia (Fuerzas Armadas Revolucionarias de Colombia, FARC) and government measures to help FARC members reintegrate into civilian society (2005February 2008), Retrieved online: www.refworld.org/docid/4829b55c23.html

Isacson, Adam and Abigail Poe (2009) After Plan Colombia: Evaluating "Integrated Action," the next phase of U.S. assistance, by Adam Isacson and Abigail Poe, CIP International Policy Report, December 2009

Jaramillo, Jaime Eduardo, Leonidas Mora and Fernando Cubides (1986 (second edition 1989)) Colonización, Coca y Guerrilla, Bogotá: Alianza Editorial Colombiana, third edition

Johnson, Chalmers (1982) MITI and the Japanese Miracle: The Growth of Industrial Policy, 1925-1975, Stanford University Press

Kaldor, Mary (1999) New and Old Wars: Organized Violence in a Global Era, Stanford University Press

Kaldor, Mary (2001) Las Nuevas Guerras: Violencia Organizada en la Era Global, Tusquets: Barcelona.

Kaldor, Mary, Terry Lynn Karl, and Yahia Said (2007) Oil Wars, Pluto Press

Kaplan, Oliver (2012) Shootings and Shamans: Local Civilian Authority Structures and Civil War Violence in Colombia. Retrieved online: http://dx.doi.org/10.2139/ssrn.2102751

Kalyvas, Stathis (2003) The Ontology of Political Violence: Action and Identities in Civil War, in Perspective on Politics, Issue 3, pp.475-494

Kalyvas, Stathis (2006) The Logic of Violence in Civil War, Cambridge University Press 
Kay, Bruce H (2007) Violent Opportunities: The Rise and Fall of 'King Coca' and Shining Path, in Journal of Interamerican Studies and World Affairs, vol. 41

Keen, David (1998) The Economic Functions of Violence in Civil Wars, Routledge

Kent, Robert B. (1993) Geographical dimensions of the Shining Path insurgency in Peru, in Geographical Review, Vol 83(4), pp. 441-456

Kurtz-Phelan, Daniel (2005) “Coca is Everything Here": Hard Truths about Bolivia's Drug War, in World Policy Journal, 22(3), pp. 103-102

Krauthausen, Ciro, and Luis Fernando Sarmiento (1991) Cocaína \& Co.: un mercado ilegal por dentro, Bogotá: Tercer Mundo

Labrousse, Alaine (2005) The FARC and the Taliban's Connection to Drugs, in The Journal of Drug Issues, Vol. 35, pp. 169-84

Landel, Morgane (2010) Are Aerial Fumigations in the Context of the War in Colombia a Violation of the Rules of International Humanitarian Law in Transnational Law \& Contemporary Problems, 19(491), pp. 492-513

Le Billion, Phillipe (2001) The political ecology of war: natural resources and armed conflicts, in Political Geography, 20, pp. 561-584

Le Billion, Phillipe (2005) Fuelling War: Natural resources and armed conflict, Routledge

Lavaux, Stéphanie (2007) Natural Resources and Conflict in Colombia: Complex Dynamics, Narrow Relationships, in International Journal 62(1), pp. 19-30

Lidow, Nicholai (2010) Rebel Governance and Civilian Abuse: Comparing Liberia's Rebels Using Satellite Data, APSA 2010 Annual Meeting. Available: http://ssrn.com/abstract=1643030

López Báez, Camilo (2007) Recomposición de las sociedades rurales en zonas de conflicto armado: el caso de la cuenca del río Caguán, in Revista Colombiana de Sociología, 28. Online: http://www.revistas.unal.edu.co/index.php/recs/article/view/8004Lozano (2000) FARC Caquetá Mahoney, James, and Dietrich Rueschemeyer (eds) (2003) Comparative Historical Analysis in The Social Sciences, Cambridge: Cambridge University Press

Makarenko, Tamara (2004) The Crime-Terror Continuum: Tracing the Interplay between Transnational Crime and Terrorism, in Global Crime, 6(1), pp. 129-145

Mampilly, Zacharaiah Cherian (2011) Rebel Rulers: Insurgent Governance and Civilian Life During War, University of Cambridge Press

Mann, Michael (1984) The Autonomous Power of the State: It's Origins, Mechanisms, and Results, in Archives européennes de sociologie, Vol. 25, pp. 185-213 
Mann, Michael (1986) The Sources of Social Power: Volume 1, A History of Power from the Beginning to $A D$ 1760, Cambridge University Press

Mason, Ann (2003) Colombia's Democratic Security Agenda: Public Order in the Security Tripod, in Security Dialogue, Vol. 34(4), pp. 391-409

Matta Aldana, Luis Alberto, (1990) Colombia y las FARC-EP, Origen de la lucha guerrillera, Testimonio del comandante Jaime Guaraca, Editorial Txalaparta Mazzei

McClintock, Cynthia (1984) Why Peasants Rebel, The Case of Peru's Senero Luminoso, in World Politics, 37(1), pp. 48-84

McClintock, Cynthia (1988) The War on Drugs: The Peruvian Case, in the Journal of Interamerican Studies and World Affairs, 30(2/3), pp. 127-142

Medina Arbeláez, Camila (2009) No porque seas paraco o seas guerrillero tienes que ser un animal, Procesos de socialización en FARC-EP, ELN y grupos Paramilitares (1996-2006), Universidad de Los Andes

Medina Gallego, Carlos (1990) Autodefensas, paramilitares y narcotráfico en Colombia: origen, desarrollo y consolidación, el caso Puerto Boyacá, Bogotá, CO : Editorial Documentos Jurídicos

Medina Gallego, Carlos (1997) Violencia y lucha armada: El caso del ELN. Una historia de vida (1958-1978), Tesis de Maestría en Historia, Universidad Nacional de Colombia-sede Bogotá

Mejía, Daniel (2011) The War on Drugs Under Plan Colombia, in Rethinking the 'War on Drugs' through the U.S.-Mexico Prism, Yale Center for the Study of Globalization. Retrieved online: http://www.ycsg.yale.edu/center/forms/plan-colombia19-32.pdf

Mejía, Daniel (2012) The War on Drugs under Plan Colombia, Yale Center for the Study of Globalization. Online: http://www.ycsg.yale.edu/center/forms/plan-colombia19-32.pdf

Metelits, Claire (2010) Inside Insurgency: Violence, Civilians, and Revolutionary Group Behavior, NYU Press

Mill, John Stuart (1967) Essays on Economics and Society (Collected Works of John Stuart Mill, Volumes 4-5), University of Toronto Press

Molano, Alfredo (1987) Selva Adentro, Una Historia Oral de la Colonización del Guaviare, El Áncora Editores

Moore, Barrington (1978; reprint 1993) Social Origins of Dictatorship and Democracy: Lord and Peasant in the Making of the Modern World, Beacon Press

Moser, C. and Clark, F. (2001) Victims, Perpetrators, or Actors? Gendered Armed Conflict and Political Violence, New York: St. Martin Press

Mullikin, Lindsey (2008) Bolivia: Coca Si, Cocaina no?: Evo Morales’ Coca Policy in Los 
Yungas, Bolivia, Pulitzer Center on Crisis Reporting: http:www.pulitzercenter.org/projects

Munck, Luis (2004) Tools for Qualitative Research, in Brady, Henry E. and David Collier (eds.), Rethinking Social Inquiry: Diverse Tools, Shared Standards, pp. 105-21, Boulder, Col. and Berkeley, Cal.: Rowman \& Littlefield and Berkeley Public Policy Press

Occidental Petroleum Corporation, Improving Housing and Living Conditions in Colombia. Retrieved online: http://www.oxy.com/sr/HumanRights/Pages/Overview

O’Donnell, Guillermo A. (1994) Delegative Democracy, in Journal of Democracy, Vol. 5(1), pp. 55-69

Oquist, Paul H. (1980) Violence, Conflict, and Politics in Colombia, Academic Press

Ortiz, Román D. (2002) Insurgent Strategies in the Post-Cold War: The Case of the Revolutionary Armed Forces of Colombia, in Studies in Conflict \& Terrorism, 25, pp. 127-143

Oxhorn, Philip (2009) Beyond Neoliberalism? Latin America's New Crossroads, in Burdick, John, Philip Oxhorn, and Kenneth M. Roberts (eds.) Beyond Neoliberalism in Latin America?: Societies and Politics at the Crossroads, pp. 217-234, Palgrave Macmillan

Parsons, Talcott (1960) Structure and Process in Modern Societies, Free Press

Pataquiva Garcia, German Nicolas (2007) ¿Pretendieron Las FARC construir un estado en la Zona del Caguán?, Master Thesis in Political Science, Pontificia Universidad Javeriana, Bogotá. Accessed through Pontificia Universidad Javeriana Library Services in Bogotá, Colombia

Pearce, Jenny (2004) Beyond the Perimeter Fence: Oil and Armed Conflict in Casanare, Colombia, Discussion Paper 32, The Centre for global Governance, LSE, November 2004.

Pearce, Jenny (2005) Mas Allá de la Malla Perimetral, El Petróleo y el Conflicto Armado en Casanare, Colombia, Bogotá: CINEP

Pécaut, Daniel (1997) Presente, Pasado y Futuro de la violencia en Colombia, in Desarrollo Económico, 36(144)

Pécaut, Daniel (2001) Guerra contra la Sociedad, Bogotá: Editorial Planeta Colombiana

Pécaut, Daniel (2008) Las FARC: ¿una guerrilla sin fin o sin fines?, Bogotá: Grupo Editorial Norma

Peñate, Andrés (1998) El sendero estratégico del ELN: del idealismo guevarista al clientelismo armado, working paper \# 15, Centro de Estudios Sobre Desarrollo Económico

Perl, Raphael F. (1992) United States Andean Drug Policy: Background and Issues for Decision makers, in Journal of International Studies and World Affairs, 34(3), pp.13-35

Perl, Raphael F. (2001) Taliban and the Drug Trade, Congressional Research Services (CRS), Report for Congress No. RS21041 
Pizarro Leongómez, Eduardo (2003) A New Approach: Álvaro Uribe’s Democratic Security Project. Inter-American Dialogue Special Working Paper Series, Colombia. Online:

www.thedialogue.org

Pizarro Leongómez, Eduardo (2011) Las Farc (1949-2011) De guerrilla campesina a máquina de guerra, Bogotá: Grupo Editorial norma

Porter, Bruce D. (2002) War and the Rise of the State, Free Press

Puentes Marín, Angela Maria (2006) El Opio de Los Taliban y La Coca de Las Farc:

Transformaciones de La Relacion Entre Actores Armados y Narcotrafico En Afganistan y Colombia, Ediciones Uniandes

Rabasa, Angel (2001) Colombian Labyrinth: The Synergy of Drugs and Insurgency and Its Implications for Regional Stability. RAND 
Rabasa, Angela and Peter Chalk (2001) Colombian Labyrinth, The Synergy of Drugs and Insurgency and Its Implications for Regional Stability, RAND

Ramírez Tobón, William (1981) La guerilla rural en Colombia: una vía hacia la colonización armada. Estudios Rurales Latinoamericanos, Vol 4(2)

Rangel Suarez, Alfredo (1997) Las FARC-EP: Una Mirada Actual. Universidad de los Andes, Centro de Estudios Sobre Desarrollo Económico (CEDE) Documento de Trabajo $\mathrm{N}^{\circ} 3$. Retrieved online: http://economia.uniandes.edu.co/investigaciones_y_publicaciones/CEDE

Ragin, Charles C. (2000) Fuzzy-Set Social Science, University of Chicago Press

Randall, Stephen J. and Jillian Dowding (2006) Colombia: Current and Future Political, Economic and Security Trends:

http://www.cdfai.org/PDF/Current\%20and\%20Future\%20Political,\%20Economic\%20and\%20Se curity\%20Trends\%20.pdf

Ramírez, María Clamencia (2003) The Cocalero Social Movement of the Amazon Region of Colombia. Online: http://drclas.harvard.edu/publications/revistaonline/spring-2003/cocalerosocial-movement-amazon-region-colombia

Ramírez, María Clamencia (2011) Between the Guerrillas and the State: The Cocalero Movement, Citizenship, and Identity in the Colombian Amazon, Duke University Press

Rangel Suárez, Alfredo (2000) Parasites and Predators: Guerrillas and the Insurrection Economy of Colombia, in Journal of International Affairs, 53(2), pp. 577

Rangel Suárez, Alfredo (1998) Colombia: Guerra en el fin del siglo, Bogotá: Tercer Mundo Editores, 1998, pp. 125-126

Reed, Brian (2007) A Social Network Approach to Understanding an Insurgency, U.S. Army War College: http://www.dtic.mil/dtic/tr/fulltext/u2/a486072.pdf

Richani, Nazih (2002) Systems of Violence, The Political Economy of War and Peace in Colombia, State University of New York Press

Richani, Nazih (2005) Multinational Corporations, Rentier Capitalism, and the War System in Colombia, in Latin American Politics and Society, Vol. 47(3), pp. 113-144

Rodríguez Pizarro, Alba Nubia (2005) Acciones colectivas en el conflicto político colombiano: ¿De guerrilla a grupos terroristas? El caso del ELN, in Política y Sociedad, 42 (2), pp. 133-147 
Romero Vidal, Mauricio (2003) Paramilitares y Autodefensas, 1982-2003, Editorial PlanetaIEPRI

Ross, Michael (2003) Oil, Drugs and Diamonds: They Varying Roles of Natural Resources in Civil Wars, in Karen Ballentine and Jake Sherman (eds.) The Political Economy of Armed Conflict, Boulder CO: Lynne Rienner Publishers, pp. 47-70

Ross, Michael (2004) What do we know about Natural Resources and Civil War?, Journal of Peace Research, 41(3), pp. 337-356

Ross, Michael (2008) Blood and Barrels: Why Oil Wealth Fuels Conflict, in Council on Foreign Affairs 87(3), May-June 2008

Rueda, Zenaida (2009) Confesiones de una Guerrillera, Los Secretos de Tirofijo, Jojoy y las $F A R C$, Revelados por primera vez, Bogotá: Editorial Planeta Colombiana S.A.

Ruiz, Edgar (2001) El Tratamiento de las contradicciones internas, in Las Verdaderas Intenciones del ELN, Corporación Observatorio para la Paz, Bogotá: Intermedio Editores, pp. 187-193

Samuelson, Paul A. (1954) The PureTheory of Public Expenditure, in The Review of Economics and Statistics, Vol. 36(4), pp. 387-389

Sánchez, Gonzalo and Donny Meertens (1983; reprint 2001) Bandits, Peasants, and Politics, the Case of 'La Violencia' in Colombia, Austin TX: University of Texas Press

Sánchez, Gonzalo (1998) Colombia: Violencias sin futuros, in Foro Internacional Vol. 38(1), pp. $37-58$

Sánchez, Gonzalo (2001) Introduction: Problems of Violence, Prospects for Peace, in Bergquist, Charles, Ricardo Peñaranda, and Gonzalo Sánchez (eds.), Violence in Colombia 1990-2000:

Waging War and Negotiating Peace, Wilmington, DE: Scholarly Resources

Sánchez, Fabio and María Del Mar Palau (2006) Conflict, Decentralisation And Local Governance In Colombia, 1974-2004, DOCUMENTOS CEDE 002180, UNIVERSIDAD DE LOS ANDES-CEDE

Schutt, Russell (2009) Investigating the Social World, The Process and Practice of Research, Pine Forge Press

Scott, James (1992) Domination and the Arts of Resistance: Hidden Transcripts, Yale University Press 
Solomon, Keith R., Arturo Anadón, Antonio Luiz Cerdeira, Jon Marshall, Luz Helena-Sanin (2005) Environmental and Human Health Assessment of the Aerial Spray Program for Coca and Poppy Control in Colombia, A report prepared for the Inter-American Drug Abuse Control Commission (CICAD) Section of the Organization for American States (OAS), Washington D.C., March 31, 2005

Snyder, Richard and Angelica Duran-Martinez (2009) Does Illegality breed violence? Drug trafficking and state-sponsored protection rackets, in Crime, Law, and Social Change, 52(3), pp. 253-273

Soto-Trillo, Eduardo (2001) Voces sin voz, Revelaciones de un viaje a la zona del despeje, Bogotá, Colombia: Licencia de Editorial Primer Latinoamericana Ltda.

Restrepo, Jorge and Spagat, Michael (2004) The Colombian Conflict: Uribe's First 17 Months, CEPR Discussion Papers 4570, C.E.P.R. Discussion Papers.

Staniland, Paul (2012) Organizing Insurgency: Networks, Resources, and Rebellion in South Asia, in International Security, Vol. 37(1), pp. 142-177

Stern, Orin (1995) To Revolt against the Revolution: War and Resistance in Peru's Andes, in Cultural Anthropology, 10(4), pp. 547-580

Thompson, David P. (1996) Pablo Escobar, Drug Baron: His Surrender, Imprisonment, and Escape, in Studies of Conflict and Terrorism, Vol. 19, pp. 55-91

Thoumi, Francisco E. (1995) Political Economy and Illegal Drugs in Colombia, Lynne Rienner Publishers

Tickner, Arlene Beth, Diego García, and Catalina Arreaza (2011) Actores violentos no estatales y narcotráfico en Colombia, pp. 413-458 in Gaviria Uribe, Alejandro and Daniel Mejía Londoño (eds), Políticas antidroga en Colombia: éxitos, fracasos, y extravíos, Ediciones Uniandes

Tilly, Charles (1992) Coercion, Capital and European States: AD 990 - 1992, Wiley-Blackwell

Tilly, Charles (2003) The Politics of Collective Violence, Cambridge University Press

Tse-tung, Mao (2009) On Guerilla Warfare, Create Space Independent Publishing Platform

United Nations Office on Drugs and Crime (UNODC) (2003) Global Illicit Drug Trends 2003: http://www.unodc.org/pdf/trends2003_www_E.pdf 
United Nations Office on Drugs and Crime (UNODC) (2007) World Drug Report 2007:

http://www.unodc.org/pdf/research/wdr07/WDR_2007_2.3_coc_usa.pdf

United States Government Accountability Office Report GAO-05-97

United States Department of State (2002) Report to Congress on Caño Limón Pipeline. Retrieved online: www.latinamaericanstudies.org/colombia/pipeline-report.htm

Uribe, Graciela (2001) Presencia de las Farc en el Caquetá, *unpublished document obtained during autor interview with Graciela Uribe in Bogotá, Colombia, November, 2011

Uribe Ramón, Graciela and Juan Ferro (2002) Las marchas de los cocaleros del departamento de Caquetá, Colombia: contradicciones políticas y obstáculos a la emancipación social', in Cuadernos de Desarrollo Rural 49, pp. 59-84.

Vargas, Ricardo (2002) The Anti-Drug Policy, Aerial Spraying of Illicit Crops and Their Social, Environmental and Political Impacts in Colombia, in The Journal of Drug Issues, pp.11-35 Vargas, Gonzalo (2009) Armed Conflict, Crime and Social Protest in South Bolívar, Colombia (1996-2004), Working Paper \#65 on Cities and Fragile States, Crisis States Working Papers Series No.2

Vargas, Gonzalo (2011) Drugs, Hearts and Minds: Irregular War and the Coca Economy in South Bolivar, Colombia (1996-2004), in Civil Wars 13(1), pp. 21-39

Villamarin Pulido, Luis Alberto (1996) El Cartel de las Farc, Bogotá: Ediciones Luis Alberto Villamarin Pulido

Vicepresidencia de la Republica (2002) Panorama Actual de los municipios que conformaron la zona de distension, Observatorio del Programa Presidencial de Derechos Humanos y DIH: http://reliefweb.int/sites/reliefweb.int/files/resources/DBAA1F458A529C97C1256E29003CC99 7-govcol-col-28jan.pdf

Watts, Michael (2008) Imperial Oil: The Anatomy of a Nigerian Oil Insurgency, Working Paper \#17, Economies of Violence Niger Delta Working Papers

Weber, Max (1958) The three types of legitimate rule, in Berkeley Publications in Society and Institutions, 4 (1), pp. 1-11. Translated by Hans Gerth

Weinstein, Jeremy (2007) Inside Rebellion: The Politics of Insurgent Violence, Cambridge University Press

Wickham-Crowley, Timothy P. (1987) The Rise (And Sometimes Fall) of Guerilla Governments in Latin America, in Sociological Forum, 2(3), pp. 473-499 
Wickham-Crowley (1992) Guerrillas and Revolution in Latin America, Princeton University Press

Wood, Elizabeth Jean (2003) Insurgent Collective Action and Civil War in El Salvador, Cambridge University Press 